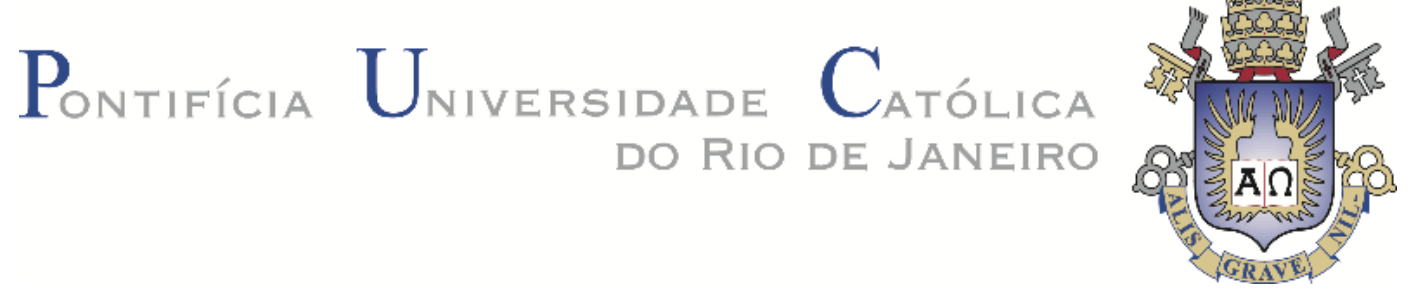

Mirna Juliana Santos Fonseca

PRODUÇÃO AUDIOVISUAL EM UMA ESCOLA MUNICIPAL DO RIO DE JANEIRO: pedagogia audiovisual e habilidades sociocognitivas

Tese de Doutorado

Tese apresentada ao Programa de Pós-graduação em Educação da PUC-Rio como requisito para obtenção do grau de Doutora em Educação.

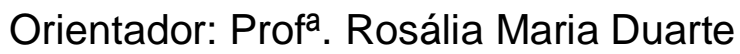




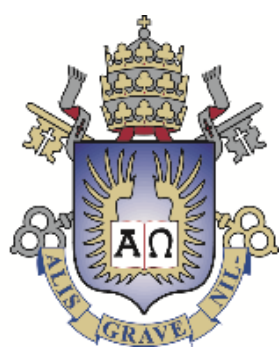

Mirna Juliana Santos Fonseca

\section{Produção audiovisual em uma escola municipal do Rio de Janeiro: pedagogia audiovisual e habilidades sociocognitivas}

Tese apresentada como requisito para obtenção do grau de Doutora pelo Programa de Pós-graduação em Educação do Departamento de Educação do Centro de Teologia e Ciências Humanas da PÚC-Rio. Aprovada pela Comissão Examinadora abaixo assinada.

Profa. . Rosália Maria Duarte Orientadora

Departamento de Educação - PUC-Rio

Profa. Magda Pischetola Departamento de Educação - PUC-Rio

Profa. Adriana Mabel Fresquet Departamento de Educação - UFRJ

Profa. Raquel Pacheco Mello Cunha Depto de Ciências da Comunicação - Universidade Nova de Lisboa

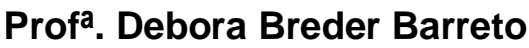
Departamento de Educação - UCP

Profa. Monah Winograd

Coordenadora Setorial do Centro de Teologia e Ciências Humanas - PUC-Rio

Rio de Janeiro, 28 de fevereiro de 2019. 
Todos os direitos reservados. É proibida a reprodução total ou parcial do trabalho sem autorização do autor, do orientador e da universidade.

\section{Mirna Juliana Santos Fonseca}

Licenciada em Letras-Francês pela Universidade Federal do Ceará (2004). É especialista em Língua Francesa - Tradução pela Universidade do Estado do Rio de Janeiro (2010). No mestrado em Educação, realizado na Universidade Federal do Estado do Rio de Janeiro (2014), pesquisou sobre a dimensão formativa de cineclubes universitários. É integrante do Grupo de Pesquisa em Educação e Mídias (Grupem) desde 2015. Publica e pesquisa sobre: cinema e educação; cineclubismo e educação; produção audiovisual na escola; pedagogia audiovisual; mídias e educação; TICs. É revisora de textos.

Ficha Catalográfica

Fonseca, Mirna Juliana Santos

Produção audiovisual em uma escola municipal do Rio de Janeiro : pedagogia audiovisual e habilidades sociocognitivas / Mirna Juliana Santos Fonseca ; orientadora: Rosália Maria Duarte. - 2019. 219 f. : il. color. ; $30 \mathrm{~cm}$

Tese (doutorado) - Pontifícia Universidade Católica do Rio de Janeiro, Departamento de Educação, 2019.

Inclui bibliografia

1. Educação - Teses. 2. Produção audiovisual na escola. 3. Pedagogia audiovisual. 4. Habilidades sociocognitivas. 5. Cinema e educação. 6. Mídia-educação. I. Duarte, Rosália Maria. II. Pontifícia Universidade Católica do Rio de Janeiro. Departamento de Educação. III. Título. 
Dedico esta tese a todas as mulheres a quem foi (ou será) negada a escolha de fazer aquilo que sonham.

Dedico também àquelas que conseguiram(ão) realizar seus sonhos, mostrando ao patriarcado que somos mais fortes do que se imagina. 


\section{Agradecimentos}

Ao CNPq e ao Programa de Pós-Graduação em Educação da PUC-Rio, pelas bolsas concedidas no decorrer do doutorado.

Agradeço à comunidade escolar e ao professor que abriu as portas de sua oficina de produção audiovisual para que eu observasse suas aulas durante o ano de 2017. Sua atitude foi de grande generosidade não apenas para a minha pesquisa, mas para o campo em que esta tese se insere. Agradeço aos alunos que observei nessa oficina: sem eles nada do que apresento nestas páginas teria se materializado em uma tese de doutorado.

Ao Grupem, que sempre me auxiliou em relação à pesquisa, em especial a: Elizabeth Caldas, Beatriz Porto, Daniela Oliveira, Lílian Cavalcante, Patrícia Teixeira Sá, Thaís Gomes e Carolina Morales.

À banca examinadora, Magda Pischetola, Debora Breder, Raquel Pacheco e Adriana Fresquet, por reservarem parte do seu precioso tempo para avaliar esta tese.

À Rosália Duarte, que além de orientar esta pesquisa com olhar atento, ensinoume sobre ser pesquisadora e sobre como estudar e escrever como tal. Levarei seus ensinamentos como quem guarda cartas de pessoas muito queridas, para que eu sempre os revisite quando necessário. Obrigada!

Às amigas que o doutorado me deu com a turma B de 2015, que foi um canal de muitas alegrias, mas também de trocas acadêmicas e de vida, desde o início do doutorado. Muito obrigada: Dila Carvalho, Sandra Marcelino, Rachel Pulcino, Liliane Balonecker, Keite Melo, Luisa Figueiredo, Thamiris Lopes, Vanessa Weber e Thiago Nascimento. Às colegas que fui encontrando durante esses quatro anos pela PUC, presentes que o doutorado me deu: Carla Machado e Elisabete Ramos.

A Kelly Maia e Margarete Mesquita, que acompanharam de perto esse processo, sempre torcendo por mim e ajudando nas transcrições e leituras dos meus escritos.

Às amigas e amigos que torceram por mim e demonstraram isso de forma incrível durante a reta final desse doutorado, respeitando meus momentos de silêncio e distanciamento: "Aqueles que me ajudaram sabem que o fizeram e quanto. Espero que agora eles saibam que eu o reconheço." - Clifford Geertz.

À minha mãe, Francisca Mirna, por todo apoio e pela "psicóloga a distância" que se fez nos últimos meses de escrita. Sei o quanto você torce e ora por mim, nossa parceria vai longe!

Ao Jorge Menezes, amor da minha vida, que do seu jeito, com sua comida maravilhosa e seu carinho me alimentou de esperança sobre mim mesma em relação a este doutorado. Obrigada por andar ao meu lado!

O presente trabalho foi realizado com apoio da Coordenação de Aperfeiçoamento de pessoal de Nível Superior - Brasil (Capes) - código de financiamento 001. 


\section{Resumo}

Fonseca, Mirna Juliana Santos; Duarte, Rosália Maria. Produção audiovisual em uma escola municipal do Rio de Janeiro: pedagogia audiovisual e habilidades sociocognitivas. Rio de Janeiro, 2019. 219p. Tese de Doutorado - Departamento de Educação, Pontifícia Universidade Católica do Rio de Janeiro.

A pesquisa teve por objetivo descrever e analisar o processo de ensinoaprendizagem da linguagem audiovisual na escola, buscando identificar conhecimentos e habilidades desenvolvidas pelos estudantes nesse processo. Para isso, foram feitas observações das atividades realizadas em uma oficina de vídeo ministrada para alunos do $2^{\circ}$ segmento do ensino fundamental em uma escola pública municipal do Rio de Janeiro, durante o ano de 2017. Para o registro das observações, utilizou-se diário de campo e gravações em áudio das aulas. Além disso, foi construído e utilizado um protocolo com indicadores de atitudes, conhecimentos e habilidades adquiridos pelos participantes das oficinas, em relação a: trabalho em equipe e realização/cumprimento/resolução de tarefas conjuntas, capacidade de empatia, planejamento de atividades/tarefas para médio e longo prazos, capacidade de argumentação e de escuta do outro, organização de tarefas em diferentes etapas, e transcodificação de linguagens. Também foram realizadas entrevistas semiestruturadas com o professor da oficina, outros professores da escola, a diretora e com os alunos participantes da oficina. Buscou-se, ainda, analisar a pedagogia audiovisual adotada pelo professor no processo de produção audiovisual investigado, identificando procedimentos e pressupostos teórico-metodológicos que a integram, à luz da literatura de referência sobre o tema. Nessa análise, a pesquisa tomou como referência duas vertentes teóricas que orientam processos pedagógicos de produção audiovisual na escola: teoria e prática de ensino de cinema e teoria e prática em mídia-educação. As perspectivas são compreendidas, aqui, como complementares para a produção audiovisual na escola, podendo ser acessadas pelos professores conforme seus objetivos. A pedagogia do professor parte da geração de ideias, escrita do roteiro, divisão de papéis e filmagens, sendo analisada como uma proposta mais próxima dos pressupostos da mídiaeducação, ao tentar simular a criação de um filme. A análise de sua metodologia indica que o processo de escrita do roteiro propicia a criação coletiva e a expressão de ideias, atendendo, assim, aos objetivos do professor, porém, deixando de cumprir partes importantes para uma experiência com a produção 
de filmes na escola, como a análise e debates de filmes e a edição e apresentação do filme produzido pelo grupo. As habilidades sociocognitivas promovidas nessa oficina de vídeo foram: trabalho em equipe, empatia e capacidade de argumentação; as habilidades concernentes a planejamento e organização de tarefas e transcodificação de linguagens não foram verificadas nessa oficina, assim como habilidades relacionadas à produção audiovisual. Esses dados são relacionados à maior atenção à construção do roteiro, com pouco tempo dedicado às filmagens e visualização do material produzido.

\section{Palavras-chave}

Produção audiovisual na escola; Pedagogia audiovisual; Habilidades sociocognitivas; Cinema e educação; Mídia-educação. 


\section{Abstract}

Fonseca, Mirna Juliana Santos; Duarte, Rosália Maria (Advisor). Audiovisual production in a municipal school of Rio de Janeiro: audiovisual pedagogy and sociocognitive skills. Rio de Janeiro, 2019. 219p. Tese de Doutorado - Departamento de Educação, Pontifícia Universidade Católica do Rio de Janeiro.

The aim of the research was to describe and analyze the teaching-learning process of the audiovisual language in the school, seeking to identify the knowledge and skills developed by the students in this process. For this, observations were made of the activities carried out in a video workshop given to students of the 2nd elementary school segment in a municipal public school in Rio de Janeiro, during the year 2017. In order to record the observations, field diary and audio recordings of classes. In addition, a protocol with indicators of attitudes, knowledge and skills acquired by workshop participants was constructed and used in relation to: teamwork and accomplishment/ fulfillment/ resolution of joint tasks, empathy capacity, activity/task planning for medium and long term, ability to argue and listen to the other, organization of tasks in different stages, and transcoding of languages. Semi-structured interviews were also conducted with the workshop teacher, other school teachers, the principal, and the students participating in the workshop. It was also sought to analyze the audiovisual pedagogy adopted by the teacher in the process of audiovisual production investigated, identifying procedures and theoretical and methodological assumptions that integrate it, in light of the reference literature on the subject. In this analysis, the research took as reference two theoretical aspects that guide pedagogical processes of audiovisual production in school: theory and practice of teaching cinema and theory and practice in media education. The perspectives are understood here as complementary to the audiovisual production in the school, and can be accessed by teachers according to their objectives. The pedagogy of the teacher starts with the generation of ideas, script writing, division of roles and filming, and is analyzed as a proposal closer to the assumptions of media education when trying to simulate the creation of a film. The analysis of its methodology indicates that the writing process of the script proposing collective creation and the expression of ideas, thus meeting the objectives of the teacher, but let himself fulfill important parts for an experience with the production of films in school, such as the analysis and discussions of films and the edition and presentation of the film produced by the group. 
Sociocognitive skills promoted in this video workshop were: teamwork, empathy and ability of arguments. The skills concerning the planning and organization of tasks and transcoding of languages were not verified in this workshop, as well as skills related to audiovisual production. These data are related to the greatest attention to the construction of the script, with a little time dedicated to the filming and visualization of the material produced.

\section{Keywords}

Audiovisual production at school; Audiovisual pedagogy; Sociocognitive skills; Cinema and education; Media-education. 


\section{Sumário}

1 Apresentação 13

2 Introdução 18

3 A pesquisa sonhada e a pesquisa vivida 26

3.1 Delimitação do campo 29

3.2 A pesquisa pensada: instrumentos 30

3.3 Escola da pesquisa 42

3.4 Situação de contato $\quad 44$

3.5 Sujeitos da pesquisa $\quad 46$

$\begin{array}{ll}3.6 \text { Oficinas } & 61\end{array}$

3.7 Atuação no campo 61

4 Olhar acadêmico sobre a produção audiovisual na escola 64

4.1 Teses e dissertações sobre produção audiovisual em contextos
educacionais

$\begin{array}{ll}4.2 \text { Artigos sobre produção audiovisual na escola } & 75\end{array}$

5 Pedagogia audiovisual e habilidades sociocognitivas 84

5.1 Pedagogia audiovisual $\quad 88$

5.2 Habilidades sociocognitivas 110

6 Oficina de cinema: pedagogia do professor 125

7 Habilidades desenvolvidas na oficina de cinema 175

8 Considerações finais 193

9 Referências 197

$\begin{array}{ll}\text { Apêndices } & 210\end{array}$ 


\section{Lista de quadros}

Quadro 1 - Especificações das visitas à escola

Quadro 2 - Dissertações sobre produção audiovisual realizada por

crianças e jovens da educação básica

72

Quadro 3 - Artigos que tratam de produção audiovisual na escola

76

Quadro 4 - Fases da produção audiovisual para o ensino nos Estados

Unidos entre as décadas de 1960-1980

Quadro 5 - Breve panorama histórico das ações com cinema nas escolas brasileiras e seus objetivos

Quadro 6 - Habilidades sociocognitivas e atitudes envolvidas na produção audiovisual escolar

Quadro 7 - Outras habilidades sociocognitivas e atitudes envolvidas na produção audiovisual escolar

Quadro 8 - Planejamento da oficina apresentado pelo professor

128

Quadro 9 - Atividades da oficina - momentos e períodos

128

Quadro 10 - Habilidades elencadas por tipo de turmas

179

Quadro 11 - Atitudes da turma final de alunos com pelo menos 4 protocolos registrados

Quadro 12 - Atitudes observadas relacionadas ao momento da oficina

Quadro 13 - Atitudes da habilidade trabalhar em equipe relacionadas ao momento da oficina

Quadro 14 - Atitudes da capacidade de empatia relacionadas ao momento da oficina

Quadro 15 - Atitudes da capacidade de argumentação relacionadas ao momento da oficina

Quadro 16 - Recorrência das habilidades coloridas por intensidade

Quadro 17 - Habilidades registradas - Carla

Quadro 18 - Habilidades registradas - Igor

Quadro 19 - Habilidades registradas - João

Quadro 20 - Habilidades registradas - Keyla

Quadro 21 - Habilidades registradas - Sueli

Quadro 22 - Habilidades registradas - Vítor

Quadro 23 - Habilidades registradas - Leo 


\section{Lista de figuras}

Figura 1 - Montagem com cartazes de eventos sobre vídeos estudantis

Figura 2 - Montagem com cartazes de eventos acadêmicos sobre cinema/audiovisual na escola

Figura 3 - Cartões para entrevista final 39

Figura 4 - Estação do BRT no bairro da escola pesquisada 42

Figura 5 - Relação com as disciplinas e a escola - Vanir 49

Figura 6 - Relação com as disciplinas e a escola - Keyla 50

Figura 7 - Relação com as disciplinas e a escola - Igor 51

Figura 8 - Relação com as disciplinas e a escola - Carla 52

Figura 9 - Relação com as disciplinas e a escola - João 53

Figura 10 - Relação com as disciplinas e a escola - Sueli 54

Figura 11 - Relação com as disciplinas e a escola - Vítor 55

Figura 12 - Relação com as disciplinas e a escola - Leo 56

Figura 13 - Relação com as disciplinas e a escola - Vita 57

Figura 14 - Relação com as disciplinas e a escola - Marcio 58

Figura 15 - Nuvem de palavras sobre percepção da produção audiovisual nas dissertações

Figura 16 - Propostas das pedagogias audiovisuais 109

Figura 17 - Produção audiovisual na escola 118

Figura 18 - Quadro na sala onde ocorre a oficina de vídeo na escola pesquisada

Figura 19 - Montagem com disposições da câmera durante as filmagens 149

Figura 20 - Primeiro dia de filmagens 157

Figura 22 - Nuvem de atitudes observadas - todas as ocorrências 181

Figura 23 - Nuvem de atitudes com maiores recorrências 195 


\section{Apresentação}

Uma pesquisa é sempre um relato de uma experiência nem sempre inédita, mas empreendida de uma maneira única (Duarte, 2002), pois é realizada e contada pela perspectiva do pesquisador, que traz consigo uma bagagem própria sobre o tema investigado e aproxima-se dos sujeitos à sua maneira, registrando aquilo que parece indicar respostas e caminhos para as questões que, naquele momento, mostram-se relevantes para a área em que a pesquisa se insere.

Iniciei meu percurso de pesquisa sobre cinema, mídias e educação durante o mestrado, quando pesquisei como a participação em cineclubes influenciava a formação de estudantes universitários. Naquele momento, pesquisei sobre o cinema em espaços de educação formal e não formal e como essa experiência poderia modificar a maneira de ensinar e aprender sobre filmes, sobre disciplinas curriculares e sobre o mundo. Nesse período, participei de atividades, eventos e grupos de pesquisa que pensavam o cinema na escola e as reverberações desse "estrangeiro" (Bergala, 2008) para o currículo e para toda a comunidade acadêmica ou escolar. Até então, minha atenção estava mais voltada para as atividades de ver filmes, mesmo que por vezes tenha flertado com temas inerentes à produção, como em disciplinas realizadas na Universidade Federal do Rio de Janeiro (UFRJ) com a professora Adriana Fresquet, que aborda a criação fílmica a partir de gestos criativos, tendo por base a proposta de Alain Bergala (2008).

Para expandir minhas impressões a respeito do cinema na escola, no doutorado lancei-me ao desafio de compreender a produção de vídeos e filmes em espaços educativos. O interesse sobre isso veio como uma necessidade de abarcar mais uma dimensão do campo em que venho me debruçando dentro da pesquisa acadêmica. O tema "produção audiovisual na escola" se insere em campos distintos do conhecimento, sendo interesse de teóricos que têm seu foco na mídia-educação e/ou no cinema e educação, ambos contribuindo, a sua maneira, para a construção do conhecimento sobre: literacia midiática, autoria, formação estética e política, alteridade, entre outros. As pesquisas oriundas de ambas as vertentes indicam a produção de vídeos e filmes na escola como propiciadora de uma experiência coletiva enriquecedora para os envolvidos, em relação à atuação em trabalhos em grupo, desenvolvimento pessoal, mudança 
de atitudes e interesse pela escola, para citar alguns resultados recorrentes sobre o tema (Barra, 2015; Berti, 2016; Cordeiro, 2013; Fantin, 2014; Gonçalves, 2013; Leite, 2012; Pimentel, 2013; Pires, 2014; Toledo, 2014).

Em 2016, como pesquisadora do Grupo de Pesquisa, Educação e Mídia (Grupem), ao qual estou vinculada, atuei na pesquisa intitulada "Projetos de mídia-educação nas escolas da Rede Pública Municipal do Rio de Janeiro e aprendizagem escolar" (doravante "pesquisa Mídia-Edu"), que buscou mapear (quanti e qualitativamente) práticas mídia-educativas na rede pública municipal de educação do Rio de Janeiro (Duarte et al., 2016), e visitei quatro escolas que indicaram ter uma vasta experiência com as mídias. Os professores que entrevistei naquele momento destacaram a relevância da experiência com a produção audiovisual na formação das crianças e jovens de suas escolas. Essa percepção também está presente nas falas de pesquisadores que apresentam seus estudos em eventos específicos sobre esse tema, nos quais a produção audiovisual dos alunos tem sido divulgada. Há também alguns festivais e mostras de cinema que direcionam parte de sua programação para a produção audiovisual escolar.

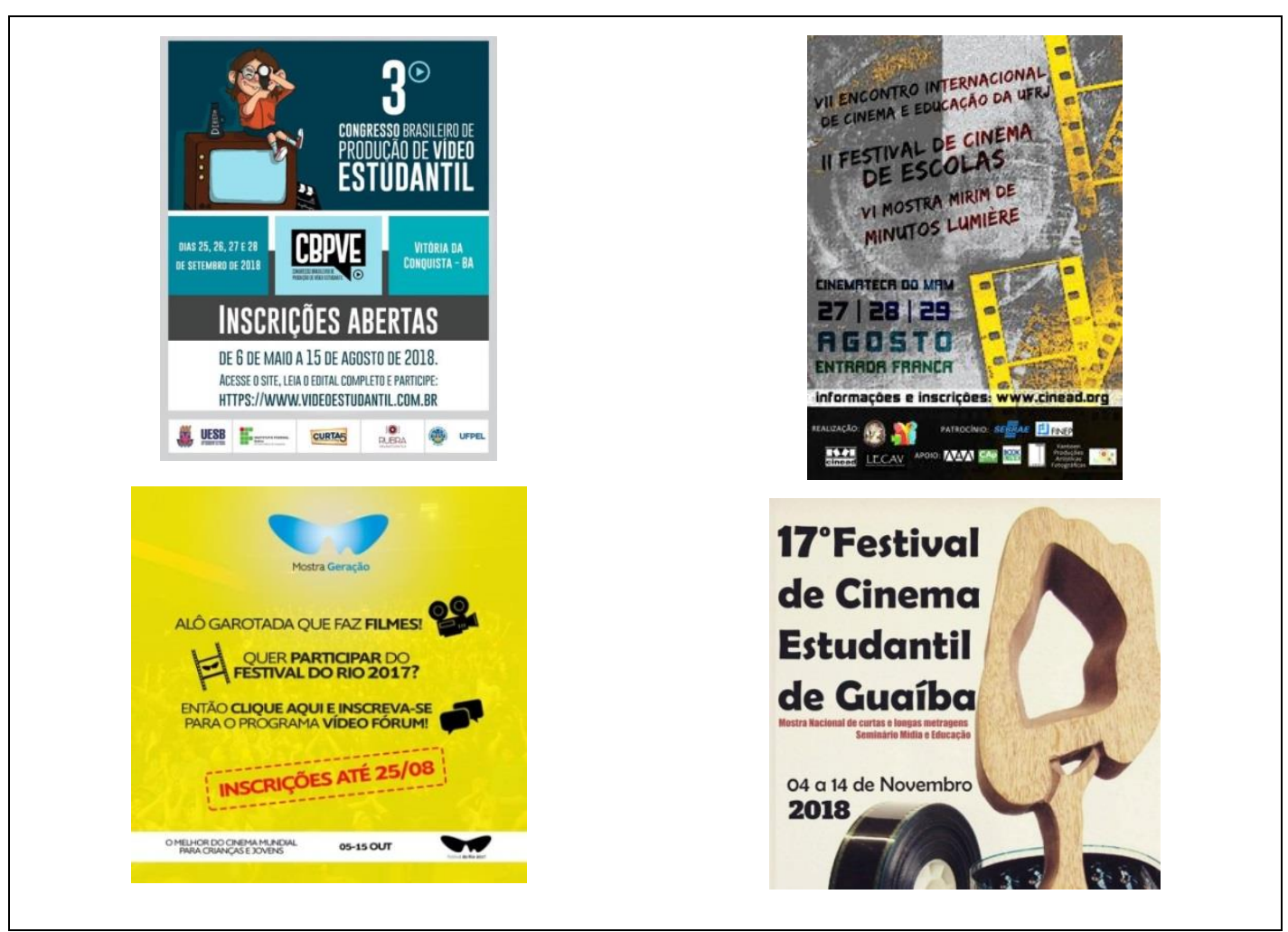

Figura 1 - Montagem com cartazes de eventos sobre vídeos estudantis Fonte: Pesquisa direta - Google Imagens. 
Alguns desses eventos são promovidos por grupos de pesquisa e/ou projetos de extensão universitária. Confirmando a relevância do tema no meio acadêmico. Alguns eventos (nacionais e internacionais) que articulam pesquisa $e$ extensão têm se voltado para a discussão dos desdobramentos do ensino de cinema e audiovisual em espaços formais e não formais de educação, cujos debates também abordam a produção de filmes por estudantes.

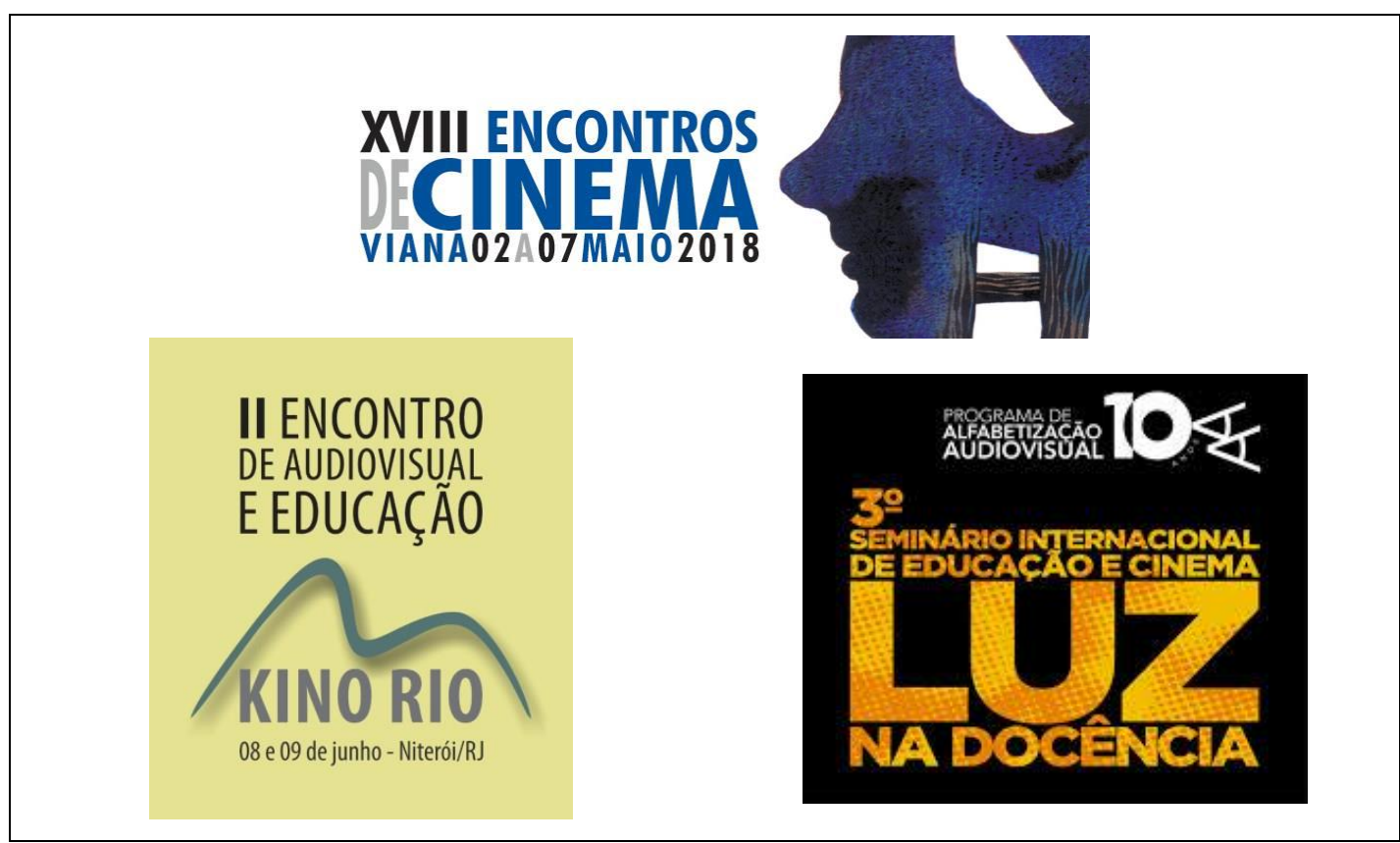

Figura 2 - Montagem com cartazes de eventos acadêmicos sobre cinema/audiovisual na escola

Fonte: Pesquisa direta - Google Imagens.

Ao justificar a presença da produção audiovisual na escola, Bete Bullara $(2018)^{1}$, secretária executiva do Cineduc: Cinema e Educação ${ }^{2}$, destaca a importância do tripé que sustenta a inserção do cinema na escola, constituído por: conhecer a história do cinema, ver e realizar filmes. Ao apresentar como a linguagem do audiovisual deve ser desenvolvida em espaços educativos para a compreensão de sua complexidade e domínio a partir da criação, Bullara compara a prática audiovisual na escola com a escrita, e as práticas de ver filmes com a leitura, e explica:

\footnotetext{
${ }^{1}$ Em entrevista ao programa \#Educa da Multirio, que abordou o tema "Cinema na escola", em 26 de junho de 2018. Disponível em: https://www.youtube.com/watch?v=JaMKV9aF9PU. Acesso em: 29 jun. 2018.

2 Organização não governamental criada em 1970 que realiza consultoria especializada nesse tema, além de eventos e formação de professores, jovens e crianças em espaços formais e não formais de educação. Maiores informações em: https://www.cineduc.org.br/. Acesso em: 2 jan. 2019. Nascimento (2013) e Santos (2016) exploram a história do Cineduc e de seus criadores.
} 
[...] quanto mais a gente escreve, melhor a gente lê; quanto mais a gente lê melhor a gente escreve. E é um círculo virtuoso aí. A pessoa começa a se expressar melhor, ter um vocabulário mais extenso, entender melhor o que o outro diz, ou o que o outro escreve. E com o cinema, com o audiovisual acontece a mesma coisa.

Parto da comparação feita por Bete Bullara para justificar meu interesse pela produção audiovisual como tema de pesquisa no doutorado em educação: quanto mais compreendi a relevância de assistir a filmes em espaços educativos para a formação de estudantes e professores ou cineclubistas, mais me questionava sobre o quanto a produção audiovisual poderia ser relevante nesse salto qualitativo para a compreensão dessa linguagem específica, questionandome sobre como tal aprendizagem poderia contribuir efetivamente para a educação dos sujeitos envolvidos nesses processos de criação, cada vez mais difundidos, seja pela questão da formação de gosto, pela elaboração política ou estética a respeito do mundo, e/ou pela construção de um domínio específico dentro do que hoje denominamos como literacia midiática.

Na pesquisa Mídia-Edu (Duarte et al., 2016), constatamos que cerca de $10 \%$ das escolas da rede pública municipal de ensino do Rio de Janeiro têm professores que promovem oficinas/aulas de produção audiovisual com seus alunos, seja produzindo animações ${ }^{3}$, ficções ou documentários. Desde meados dos anos 1970, professores dessa rede de ensino lançam mão de atividades dessa natureza ${ }^{4}$ com os alunos para ilustrar um conteúdo, dinamizar suas aulas, promover um projeto, entre outros objetivos. Entre os filmes selecionados para o Vídeo Fórum - Mostra Geração do Festival do Rio sempre há produções realizadas por alunos da rede $^{5}$, assim como ocorre em outros eventos promovidos na cidade. Sendo assim, fazer vídeos na escola pública carioca não é algo novo ${ }^{6}$, mas ainda há poucas pesquisas que abordam como se dão tais processos, suas metodologias e reverberações para a escola e a aprendizagem

\footnotetext{
${ }^{3}$ Os professores da rede frequentemente são selecionados para o festival Anima Mundi, como apresenta uma matéria divulgada no site da Secretaria Municipal de Educação, disponível em: <http://www.rio.rj.gov.br/web/sme/exibeconteudo?id=8133196>. Acesso em 13 jul. 2018.

4 Ver algumas notícias dessas atividades em: <http://www.latitude.org.br/atelie-de-midias-umaparceira-entre-a-escola-e-o-museu-mar/>; <http://www.latitude.org.br/audiovisual-nas-escolas/> ; $<$ http://www.latitude.org.br/alma-suburbana/>;

$<$ http://www.rioeduca.net/blogViews.php?bid=14\&id=5475>. Acesso em: 8 jun. 2018.

$5 \mathrm{Na}$ lista dos selecionados para o evento é possível encontrar várias escolas da rede: $<$ http://www.festivaldorio.com.br/br/noticias/conheca-os-selecionados-do-programa-video-forumdo-festival-do-rio-2017>. Acesso em: 13 jul. 2018.

${ }^{6}$ Os projetos ou oficinas de vídeos nas escolas geralmente publicam os vídeos em diversas redes sociais. Alguns estão disponíveis em: <https://www.youtube.com/channel/UCKSEx7za6o4slJzBraXPDiA>; $<$ http://nvguaratiba.blogspot.com/>; <https://www.youtube.com/channel/UCfXG8D29F00WwbeEAscV_ag>; <https://www.youtube.com/channel/UCfnMePDes28wKJzwU6Tb_tA>; $<$ https://www.youtube.com/channel/UC4SBIKr9RIC1MtzIN3JNG7g>.
} 
dos sujeitos envolvidos nessa experiência. A partir dessa lacuna no campo cinema educação, busquei compreender como são produzidos vídeos na escola e quais as pedagogias envolvidas nesse processo. Como uma oficina é elaborada? Quais os pressupostos teórico-metodológicos que a embasam? Como os alunos se envolvem com a oficina, com os colegas e com o professor? Que habilidades são promovidas ao criar filmes na escola? As respostas para essas e outras questões podem ajudar a solidificar ainda mais a relação entre cinema/audiovisual e educação. Para discutir algumas dessas questões, esta tese está dividida em sete capítulos, além desta apresentação.

$\mathrm{Na}$ Introdução, trato de onde parte a pesquisa, seus objetivos e justificativa. Ao falar d'A pesquisa sonhada e a pesquisa vivida, contextualizo o tipo de pesquisa e apresento o campo, seus sujeitos e a oficina observada durante o ano de 2017. Ao abordar o Olhar acadêmico das pesquisas sobre produção audiovisual, situo como este tema é abordado em teses, dissertações e artigos acadêmicos, nos âmbitos nacional e internacional. Os conceitos e teorias que serviram de lentes para a análise do que foi observado no trabalho de campo tratam da Pedagogia audiovisual e habilidades sociocognitivas. As análises dos dados foram divididas, em: Oficina de produção audiovisual: pedagogia do professor - em que apresento e analiso as atividades propostas pelo professor e sua metodologia - e Habilidades desenvolvidas na oficina de produção audiovisual - no qual analiso os protocolos de habilidades desenvolvidas na oficina observada. Nas Considerações finais trago meu olhar sobre toda a pesquisa desenvolvida. 


\section{2 \\ Introdução}

[...] se "há dois segredos no cinema e um não é revelado", com o audiovisual na escola podemos inventar e, quem sabe, revelar muitos outros segredos. (Fantin, 2014, p. 65).

Quando o audiovisual adentrou o/ ou foi tomado pelo campo da pedagogia, temia-se que os filmes ou a TV viessem a substituir o professor, e mais: atribuiuse a essa linguagem "a causa da crise da leitura e do empobrecimento cultural em geral", como salienta Martín-Barbero (2014, p. 45), pois o "espaço próprio da razão, do argumento, do cálculo e da reflexão" estava reservado ao livro.

O audiovisual integra as práticas escolares desde antes da invenção do cinema (Thollon-Pommerol, 1983), se considerarmos os jogos óticos que antecederam a sétima arte. DVDs educativos, palestras, animações, filmes históricos, documentários, matérias jornalísticas, vídeos do YouTube: que professor nunca recorreu a algum desses recursos em suas aulas? Os professores se utilizam desses materiais de diversas maneiras: como um instrumento para tratar conteúdos de assuntos extracurriculares (Costa, 2014; Luna, 2014; Sato, 2015; Saldanha, 2016); como uma experiência com a arte e outras linguagens (Costa Oliveira, 2011; Faria, 2011; Silva, 2017); alfabetizar o olhar (Maurício, 2010; Fantin, 2014); desenvolver autonomia e protagonismo dos estudantes (Garbin, 2011; Pires, 2014; Nogueira, 2014; Silva, 2015), entre outros diversos aspectos, como cidadania e entretenimento, já analisados por pesquisas anteriores.

O audiovisual se estabeleceu paulatinamente como algo presente nas escolas brasileiras: como instrumento, ilustração, experiência, tempo livre, tema de redação. Como tudo o que entra na escola, ele também é e está sendo apropriado pela escola. E como tudo o que passa a ser da escola, o audiovisual não tem um jeito fixo e único de estar ali. Ele está a serviço da educação: pronto para ser usado, testado, mexido, experimentado. Pode ser arte, canal, tentativa, invenção, enfim, pode ser o que os estudantes, os professores e a escola quiserem, mas precisa guardar seu frescor de entretenimento, principalmente em processos de produção (Pereira et al., 2018). Essa tarefa não é fácil quando há um propósito definido de apresentar ao final do processo um filme para a comunidade escolar, mas, assim como tudo o que é realizado na escola, os 
processos e os resultados podem ser modificados para que aprendizagens significativas aconteçam em meio aos processos de interação social em que uma oficina de produção audiovisual acontece.

Para buscar compreender como ocorre a produção audiovisual na escola, quais sentidos ela tem para estudantes e professores que participam juntos dessa experiência e como as oficinas modificam o dia a dia da escola e de seus sujeitos, é que empreendi a pesquisa aqui apresentada.

Como na rede pública municipal de educação do Rio de Janeiro há professores que produzem filmes junto com seus alunos, haja vista a participação deles em eventos educativos, cursos de formação e mostras de cinema, procurei nesse universo o campo desta pesquisa. Outro fator preponderante para esse recorte por essa opção foi minha participação, como pesquisadora, na pesquisa Mídia-Edu, que tinha por objetivo realizar o "levantamento, categorização e análise de projetos de mídia-educação e de práticas mídia-educativas nas escolas da rede pública municipal de ensino da cidade do Rio de Janeiro" (Duarte et al., 2016, p. 1). O estudo foi realizado entre 2015 e 2017, junto a diretores de 911 unidades de ensino ${ }^{7}$ da rede e, em sua primeira etapa, produziu um levantamento dos projetos de mídia-educação presentes nas escolas, tendo como foco a análise e produção de mídias na comunidade escolar. Na segunda etapa, realizada em 8 escolas, buscou analisar a estrutura, organização, objetivos e alcance de projetos e práticas de mídiaeducação, junto a professores e alunos. Participei como pesquisadora, realizando visitas às escolas para observação de como os projetos de mídiaeducação são desenvolvidos, e realização de entrevistas com gestores, professores e alunos que participam dessas atividades. Naquele momento, visitei quatro escolas do centro e da Zona Oeste do Rio de Janeiro. Em três delas havia projetos de produção audiovisual e duas promoviam, há mais de 10 anos, oficinas fora do currículo de ensino obrigatório. Essa experiência me possibilitou delinear com mais clareza meu objeto de pesquisa, que diz respeito a como se dá o processo de ensino-aprendizagem do audiovisual em contexto

\footnotetext{
${ }^{7}$ A rede municipal de ensino do Rio de Janeiro conta hoje com 1009 escolas. Portanto, pode-se afirmar que as 911 escolas que participaram da análise quantitativa representam, em termos estatísticos, $100 \%$ da rede. De acordo com Tavares, Duarte e Jordão (2016, p. 328): "A pesquisa pretendia abranger as 1009 escolas de Ensino Fundamental da rede, mas, por problemas operacionais (não foram localizados os endereços eletrônicos de todas as unidades), foram enviados questionários online (hospedados na plataforma typeform) para diretores e coordenadores pedagógicos de 994 escolas. Destes, 924 foram respondidos. Na composição da base de dados, 13 questionários tiveram que ser excluídos, em razão de dados faltantes, inconsistentes, ou ainda porque eram escolas especializadas e que não atendiam aos objetivos desse estudo. Desse modo, a amostra ficou composta por 911 escolas."
} 
escolar e às habilidades desenvolvidas pelos estudantes que participam dessas atividades.

Os resultados da pesquisa Mídia-Edu indicaram que o audiovisual nas escolas visitadas era utilizado principalmente como instrumento pedagógico, ou seja, para abordagem de conteúdos curriculares. Os professores usam projetores para dar suas aulas com auxílio da Educopédia ${ }^{8}$ ou de alguns materiais audiovisuais extraídos da internet, para apresentar temas do currículo; usam também vídeos de PPTs animados ${ }^{9}$ e de histórias infantis. Usos que, de um modo geral, se restringem à instrumentalidade dos conteúdos dos materiais audiovisuais, com pouca ou nenhuma discussão acerca de seu modo de produção e de sua condição de arte. Isso confirma o que outros pesquisadores identificam como uma prática consolidada nas escolas, conforme analisa Fantin (2014, p. 49):

O caráter de recurso ou ferramenta didática alterna-se com o caráter não intencional ou não planejado, em que se evidencia o forte uso de filmes no improviso, como substituição de professores ou de atividades, como "coringa" e ainda como "tapa buraco".

No entanto, ainda que em menor escala, a pesquisa Mídia-Edu identificou outras práticas de uso do audiovisual presentes nas escolas cariocas. Há também a organização de cineclubes e professores que promovem oficinas de vídeos, mas são ações menos recorrentes, especialmente se considerarmos o tamanho da rede em análise (1500 escolas de ensino fundamental) e a relevância da cultura audiovisual no processo de formação de gerações amplamente imersas num mundo imagético digital, que promove acesso quase permanente a narrativas audiovisuais. Como explica Franco (2014, p. 95):

\begin{abstract}
Eles veem televisão desde que mal abriram os olhos, desde cedo sabem operar equipamentos, escolhem o desenho que querem ver, vão com o dedinho no YouTube, no tablet, nos equipamentos todos. Eles sabem o que querem e sabem também porque querem, só ainda não sabem explicar, pois não chegaram ainda a um nível de operação mental racional que, como explica Piaget, depende antes de tudo do amadurecimento fisiológico do aparelho cognitivo.
\end{abstract}

A construção de uma postura crítica frente ao audiovisual é também relevante no que diz respeito à literacia midiática, conforme compreendem Livingstone (2011) e outros (Amor Pérez \& Delgado, 2012; Kearney \& Schuck, 2005; Pires, 2010). De acordo com esses autores, o domínio da linguagem

\footnotetext{
8 Plataforma com aulas e atividades disponíveis para os professores e alunos da rede em: $<$ http://www.educopedia.com.br/Index.aspx>. Acesso em: 2 set. 2016.

${ }^{9}$ Trata-se de vídeos com imagens ou fotos que vão passando como slides, geralmente com um música ao fundo.
} 
audiovisual instrumentaliza crianças e jovens a relacionar-se com os meios e através deles. De acordo com Buzato (2010), atualmente compartilhamos/vivemos um novo ethos, uma nova mentalidade, voltada à participação, conhecimento distribuído, partilha e experimentação em busca de uma troca colaborativa e do hibridismo de conteúdos, em oposição à "velha mentalidade", que compreende o conhecimento centralizado, a propriedade intelectual privada, a normatização e a difusão de conteúdos puros. Esse novo momento demanda "novos letramentos/letramentos digitais" que, conforme o autor, são produtos e produtores de hibridizações, as quais ocorrem também nas "mídias (a imprensa, o vídeo, a fotografia, o cinema, etc.)". Os novos letramentos e as apropriações tecnológicas que estes propiciam abrem:

[...] a possibilidade de transformações (inovações, aberturas de sentido, instabilidades estruturais, etc.) com as quais os que educam numa perspectivas crítica e não-conformista, precisam se engajar, se é que estão dispostos a responsabilizar-se pela própria (e de seus alunos) inclusão/exclusão. (Buzato, 2010, p. 290).

Essa perspectiva nos leva a pensar no papel da escola na construção do pensamento crítico e no que pode representar o trabalho com produção audiovisual no contexto escolar, tendo em vista a promoção de uma educação que se responsabilize pela inclusão/exclusão de professores e alunos em um novo ethos social.

Pesquisadores que discutem o uso e a produção de audiovisuais na escola e/ou cinema na escola (Bergala, 2008; Fresquet, 2011, 2013; Fantin, 2014; Toledo, 2014; Migliorin, 2011, 2014) defendem teorias e metodologias diferentes (e, a nosso ver, complementares) para integrar esse "estrangeiro" ou essa "mídia" no ambiente escolar. Cada um dos campos, à sua maneira, indica caminhos teórico-metodológicos para promover a relação crítico-analítica e estética dos estudantes com vídeos/filmes na escola: assistindo/fruindo, produzindo/experimentando, mas têm em comum a expectativa de contribuir para a vivência do audiovisual/cinema em situações educativas.

Os olhares sobre o tema seguem linhas argumentativas diferentes e consolidadas nesse campo de conhecimento e estas parecem estar presentes nas escolas. Em linhas gerais, é possível perceber duas perspectivas teóricas, uma mais voltada para a literacia, ou seja, para o desenvolvimento do domínio crítico-analítico da linguagem audiovisual, com foco na participação cidadã, e outra cujo foco é mais especificamente a formação artística, que implica uma relação mais profunda com as questões estéticas. 
O campo de estudos de literacia midiática (Belloni, 2009; Fantin, 2014; Livingstone, 2011) ou, mais especificamente, literacia digital ${ }^{10}$ (Eshet-Alkalai, 2004; McLoughlin, 2011) entende o audiovisual como recurso de comunicação e ressalta a importância de conhecer técnica e estruturalmente essa linguagem para a inserção nas sociedades contemporâneas, do mesmo modo como se precisa conhecer e dominar a linguagem escrita.

Martín-Barbero $(2000,2014)$ trata da relação entre educação e comunicação, entendendo que a escola perdeu seu lugar hegemônico de transmissora do saber e de formação e socialização das crianças e adolescentes - função compartilhada anteriormente com a família -, pois essa transmissão de saberes passou a ser agenciada pela mídia, que atua também como agente de socialização. $O$ autor analisa o papel manipulador dos meios audiovisuais como espaços espetacularizados e orientados por interesses neoliberais e critica as escolas por não oferecerem adequadamente a formação crítica para o uso das ferramentas midiáticas, especialmente a televisão. Para ele, a formação de cidadãos críticos e ativos na construção de uma sociedade justa e democrática exige, entre outras coisas, uma educação para a cultura audiovisual e digital e não apenas o uso de equipamentos como dispositivos de mediação e comunicação interpessoal.

$\mathrm{Na}$ era digital, as relações se estabelecem em tempos e espaços diferentes, com outros modos de interagir, comunicar-se e, portanto, de aprender, surgindo uma demanda para que a escola se volte para a relação entre usuários e tecnologias digitais, que solicitam de todos nós uma nova maneira de relacionar-se no e com o mundo. Os autores desse campo entendem que o audiovisual é elemento-chave nesse contexto e chamam atenção para sua onipresença nas experiências vivenciadas no mundo digital e para a necessidade de espaços educativos voltados para a formação do pensamento analítico e crítico do que é produzido na rede, pode-se partir para a produção e autoria dos alunos, passando de receptores a autores de conteúdos digitais.

As atividades de produção audiovisual têm despertado um crescente interesse pedagógico nos últimos anos, no âmbito dos estudos e práticas em

10 Os autores desse campo usam diversos termos (literacia digital/midiática, alfabetização digital/midiática, e-alfabetização, entre outros) para definir a capacidade que vai além de usar softwares e operar dispositivos digitais ou manejar adequadamente os equipamentos, abarcando uma variedade de complexos (cognitivo, motor, sociológico) e habilidades emocionais que os usuários precisam para atuar efetivamente em ambientes digitais, contando também com competência digital, cultural e comunicativa para se relacionar nas/com/pelas mídias na internet (Amor Pérez \& Delgado, 2012; Eshet-Alkalai, 2004; Livingstone, 2011; McLoughlin, 2011). Pacheco (2015) apresenta abordagens e nomenclaturas utilizadas hoje por autores e vertentes que se debruçam no estudo da educação para as mídias. 
mídia-educação (Belloni, 2009; Fantin, 2014; Hobbs \& Moore, 2014; Husbye, 2013). Para esse campo, produzir filmes é condição para compreender e analisar, pois possibilita uma melhor compreensão da gramática do audiovisual, que qualifica o espectador para ver criticamente.

A outra linha teórico-metodológica que orienta práticas de uso e produção de audiovisuais em contextos educativos no Brasil (Berti, 2016; Cohn, 2016; D’Andrea, 2018; Domingues, 2016; Garcia, 2010; Norton, 2013; Omelczuk, 2016; Silva, 2017; entre outros) envolve principalmente a experimentação com imagens em diferentes equipamentos, numa perspectiva mais autoral, com foco na formação estética. Uma das pedagogias desse campo tem como base os "gestos de criação", ancorados nas ideias de Alain Bergala (2008), que assessorou Jacques Lang na implantação dos estudos de cinema nas escolas francesas no ano 2000. De acordo com Leandro (2011, p. 114), o projeto francês considerava que a:

[...] nova pedagogia do cinema deveria apoiar-se numa abordagem do filme como arte. Isso permitiria ultrapassar os conhecimentos adquiridos da tradição linguística, semiológica e semiótica, levando a sala de aula a vivenciar a experiência do sensível proporcionada pelas obras. Em vez da pedagogia com imagem, simplesmente uma pedagogia da própria imagem.

Essa perspectiva fundamenta projetos brasileiros, como: Imagens em Movimento $^{11}$, Inventar com a Diferença ${ }^{12}$ e as escolas de cinema criadas em instituições de ensino e de saúde pelo Grupo de Pesquisa Cinead, Cinema para Aprender e Desaprender, sob a coordenação de Adriana Fresquet.

Além de Bergala, Walter Benjamin, Godard, Rancière, Deleuze e Pasolini subsidiam os estudos e práticas desenvolvidos nas escolas, com vistas a ensinar cinema para professores e estudantes. Essa perspectiva concebe o professor de cinema como um passeur ou um mediador que, muitas vezes, não possui vastos conhecimentos sobre a arte e a técnica cinematográficas, porém tem um profundo interesse em deixar-se afetar pelo cinema como arte e busca propiciar isso aos seus alunos. Migliorin (2011, p. 133) considera que:

\footnotetext{
11 O projeto Imagens em Movimento existe no Brasil desde 2011. Como apresenta o site: "Atuamos em parceria com o programa internacional 'Cinema, cem anos de juventude', criado na Cinemateca Francesa em 1995, que hoje agrega diversas organizações dedicadas à pedagogia do cinema. Trata-se de uma ação em rede, na qual cineastas, professores e estudantes de diversos países se unem para vivenciar a aventura da (re)descoberta do cinema. Juntos, vemos, debatemos e realizamos filmes ao longo de cada ano letivo, a partir de propostas pedagógicas compartilhadas." Mais informações em: http://imagensemmovimento.com.br/oprojeto/\#apresentacao. Acesso em: 22 nov. 2018.

12 Esse projeto iniciado em 2014 é desenvolvido pelo laboratório Kumã do Departamento de Cinema e Vídeo da Universidade Federal Fluminense (UFF), sob a coordenação de Cezar Migliorin, em parceria com a Secretaria Especial de Direitos Humanos. Mais informações em: http://www.inventarcomadiferenca.org/. Acesso em: 22 nov. 2018.
} 
Ensinar com o cinema passa, justamente, por um "não saber" das partes que se preparam para o acontecimento, ou seja, para a invenção intempestiva consigo e com o outro, com as imagens, mundos e conexões que o cinema nos permite, nos autoriza. Mas só o cinema pode isso? Certamente não. Mas talvez nenhuma arte ou meio de expressão o possa com tanta intensidade.

As abordagens que apresentei aqui se orientam em autores diferentes e têm objetivos diversos, porém suas metodologias convergem para uma experiência com o audiovisual, que tem por objetivo transformar, de alguma maneira, os sujeitos envolvidos nessa experiência. Nesta tese, buscarei dialogar com seus pressupostos, sempre que necessário, a fim de analisar e compreender o processo de produção audiovisual que tomei como objeto de estudo. Mais para organizar do que para tomar "partido", opto por usar o termo "audiovisual" para me referir aos produtos midiáticos e/ou artísticos que se utilizam de imagem em movimento e som na construção de um produto, obra ou narrativa. Essa escolha se dá pelo fato de "audiovisual" ser uma expressão que consegue englobar todos os tipos de produções, independente do suporte e do contexto de produção.

De acordo com Toledo (2014), as atividades que saem do modelo estabelecido de quadro e giz conseguem alcançar os alunos que apresentam baixo rendimento escolar, problemas de indisciplina, absenteísmo, problemas de relacionamento com colegas e professores, entre outros comportamentos que dificultam sua aprendizagem. Isso é especialmente válido quando se trata de produção audiovisual.

[...] seja através de oficinas ou de atividades realizadas por professores dentro da sala de aula formal, o uso do audiovisual tem promovido e estimulado a inclusão e a transformação de estudantes, uma mudança positiva, mais ligada ao desenvolvimento pessoal do que a aspectos propriamente cognitivos. (Toledo, 2014, p. 152).

Assim, a fim de ampliar a compreensão do problema, o objetivo desta pesquisa é descrever e analisar o processo de ensino-aprendizagem da linguagem audiovisual na escola, buscando identificar conhecimentos e habilidades desenvolvidas pelos estudantes.

As pesquisas nessa área indicam que o potencial da linguagem audiovisual na escola encontra-se, entre outros aspectos: na aprendizagem dos estudantes em trabalharem em grupo (D’Andrea, 2018; Garbin, 2011; Marinovic, 2012); na participação ativa de jovens e crianças (Costa, 2014; Miranda, 2011; Silva, 2017); na postura mais autônoma que os participantes apresentam após as oficinas (Garbin, 2011; Nogueira, 2014; Silva, 2017). Os pesquisadores 
confirmam que fazer filmes na escola pode auxiliar para a formação de um sujeito crítico (Faria, 2011; Dall'Agnol, 2015; Oliveira, 2015), sendo o cinema visto como uma importante ferramenta de transformação do processo educativo (Oliveira, 2011), que produz novos letramentos (Nogueira, 2014), além de ser um produtor de conhecimento/cultura/arte (Lima, 2015).

A partir dessas considerações, levanto as seguintes questões a respeito da produção audiovisual na escola: quais metodologias embasam a produção audiovisual na escola? Existe uma pedagogia estabelecida para esse tipo de atividade? Quais atitudes os alunos revelam e desenvolvem nas oficinas de cinema? Que conhecimentos e habilidades são promovidos nessa experiência educativa?

Para buscar respostas para essas questões e tentar alcançar o objetivo traçado, é necessário também:

- Identificar, descrever e analisar a pedagogia e os procedimentos adotados pelo professor no processo de produção audiovisual investigado, a partir dos pressupostos teórico-metodológicos que subsidiem a pedagogia audiovisual adotada nesse contexto de ensinoaprendizagem;

- Identificar a emergência, no grupo de aprendizes de audiovisual, de habilidades sociocognitivas, como gestão de projeto, tomada de decisão, planejamento e organização de tarefas, trabalho em equipe, argumentação, empatia e transcodificação de linguagens, entre outras, mobilizadas no processo de criação de filmes, em oficinas de audiovisual na escola.

Entendo que os processos de ensino-aprendizagem do audiovisual na escola, dependendo do modo como são conduzidos, podem se configurar como momentos e espaços privilegiados para o desenvolvimento de habilidades que instrumentalizam os alunos para lidar com seus pares e interagir em sociedade. Este trabalho buscou identificar a emergência dessas habilidades em um contexto específico de produção audiovisual escolar. 


\section{3 \\ A pesquisa sonhada e a pesquisa vivida}

Antes de entrar diretamente nos aspectos formais da metodologia adotada na pesquisa que fundamenta esta tese, preciso contar como a investigação foi construída e como o que foi pensado tornou-se o que apresentarei aqui. Há diversas questões que podem colocar "em suspeição" a presente pesquisa. Tais aspectos podem ser relevantes apenas para mim, enquanto pesquisadora do tema, mas acredito na relevância deles para a compreensão (daqueles que olham de fora) sobre a escolha do campo, a obtenção e análise dos dados e os resultados a serem apresentados.

Na seleção do doutorado em educação na PUC-Rio, apresentei um projeto com objetivo de mapear e analisar atividades de cinema com fins educativos para delineamento de uma política pública nesse campo. Naquele momento, fui questionada pela banca se não seria algo grandioso demais para um doutorado, mas consegui defender minha ideia, argumentando que geralmente desenhamos objetivos grandiosos e, se conseguirmos alcançar pelo menos uma parte deles, o projeto pode ser considerado exitoso. Outra ocasião que gostaria de lembrar desse percurso, diz respeito ao insistente questionamento de professores da pós-graduação (para mim e uma colega da área de música) sobre: "qual é mesmo a relevância da arte na escola?" Em um primeiro momento, eu e minha colega ficamos desconcertadas com a questão, imaginando que essa resposta estaria clara, mesmo que em termos gerais, para todos os cientistas da área de educação. No início, entendi como uma provocação de professor, daquelas que nos preparam para bancas de defesa; porém, por que essa questão foi feita apenas para nós, pesquisadoras de cinema e de música? Por que os professores, no decorrer da disciplina, não questionaram nossos colegas que tinham por tema a formação de professores ou currículo, por exemplo? Essas situações mexeram comigo e tenho aqui a oportunidade de refletir um pouco sobre elas e sobre esse fato.

Se em meu projeto de entrada no doutorado estivessem delineadas questões sobre a análise de atividades relacionadas ao currículo oficial, inserindo minhas questões de pesquisa em uma área "legitimada" dentro da educação, haveria algum questionamento sobre a grandeza dos meus objetivos? Se em vez de pesquisar cinema, minhas questões estivessem voltadas para a análise de livros didáticos, haveria algum questionamento por parte de alguns 
professores sobre a importância em pesquisar esse tema? Os interesses de minha pesquisa foram colocados em "suspeição" durante todo o percurso deste doutorado, inclusive por mim mesma, que cheguei a me questionar por inúmeras vezes: pra que eu fui pesquisar sobre isso? Acredito que insisti nesse tema para, como indica Da Matta (1978), colocar em questão a especificidade e a relatividade de minha própria experiência, enquanto pesquisadora de cinema/audiovisual, mídia e educação. Prova disso é que nesse caminhar publiquei o artigo "Cinema na escola para quê?" (Fonseca, 2016), como resposta não para quem me questionou, mas para mim mesma, e também a fim de contribuir para o desenho desse campo em construção. Se pessoas ligadas à educação ainda têm dúvidas a respeito da importância de pesquisas sobre esse assunto, esse pode ser um sintoma de que o campo de cinema e educação ainda não se estabeleceu fortemente dentro do meio acadêmico.

Outro aspecto que gostaria de destacar é a escolha do campo e como este se mostrou para mim. Como pesquisadora, com leituras que dão conta de como os projetos com produção audiovisual na escola estão sempre modificando o olhar de crianças e jovens sobre o mundo, inaugurando novas relações entre os participantes, criei a expectativa de acompanhar uma experiência singular e inovadora de criação fílmica na escola. Antes de entrar em campo, eu sabia que seria necessário buscar ao máximo transformar o familiar em exótico e o exótico em familiar (Da Matta, 1978) para obter dados relevantes sobre o meu objeto. Durante o que Da Matta chama de "plano teórico-intelectual", eu deveria ter muito claras as teorias e práticas sobre produção audiovisual escolar para saber como questionar o que iria observar. $E$ assim, ainda distante do campo, elaborei uma realidade de pesquisa que estava organizada dentro daquilo que eu previa de problemas e soluções, afinal, antes de entrar em campo eu testara e estudara meus instrumentos e tinha feito várias leituras que iriam embasar minha postura de observadora - que não deveria carregar em juízo de valores nas anotações nos diários de campo, por exemplo. A impressão era de que estava tudo sob controle, inclusive os possíveis percalços, e que eu já podia, destemida, passar ao que Da Matta (1978) chama de plano prático da pesquisa: o campo.

Foi nesse momento e lugar que descobri o que é uma "pesquisa qualitativa". Durante o trabalho de campo, o "quali" fez-se corpo e saltou da realidade das ideias para a realidade da pesquisa. Quando eu imaginava que tudo correria conforme previsto e que, a partir do que seria observado e ouvido, nada mais poderia acontecer, tudo mudava e tomava um rumo diferente do que 
minhas mais remotas suposições poderiam prever. Aqui entram os "hóspedes não convidados" da minha pesquisa: o medo, a dúvida, o receio de não ter uma investigação que valesse todo o esforço de quatro anos de doutorado (Da Matta, 1978).

A escrita final desta tese no decorrer deste ano de 2018 não foi tarefa fácil. A brutal execução de Marielle Franco (até então sem solução e prisão dos assassinos), a luta pela descriminalização do aborto na Argentina e no Brasil, o incêndio que destruiu o Museu Nacional, a perda de direitos trabalhistas, o processo eleitoral e a eleição de um presidente declaradamente machista, racista e homofóbico, a favor da tortura e cujo discurso contra Paulo Freire estampou sua campanha sem qualquer pudor, certamente influenciaram minha escrita. Longe de querer justificar qualquer fragilidade que porventura venha a ser encontrada nessas páginas, a menção a esses acontecimentos - pano de fundo não apenas da minha escrita, mas da vida de todos os brasileiros - é importante para situar o momento da feitura desta pesquisa, quando os horizontes se mostravam sombrios.

No início do doutorado, ainda estávamos ensaiando, por assim dizer, a entrada nessa crise neoliberal que então nos assola escancaradamente e de lá para cá os concursos para doutores são cada vez mais raros e a estabilidade no serviço público está sendo discutida. Desde 2017, ano em que comecei a pesquisa, a situação política do país em pleno golpe já estava estremecida e tanto nas redes estadual e municipal do Rio de Janeiro a instabilidade em relação a pagamentos dos servidores só aumentava os movimentos de paralisações e greve, atrapalhando aulas e deixando professores e funcionários tensos e temerosos por seu futuro. Esse último fato, especificamente, influenciou diretamente minha pesquisa, conforme descreverei em momento oportuno.

Além disso, também carrego comigo a necessidade de evidenciar a relevância das pesquisas sobre cinema e educação para as ciências humanas, porque delas eu me nutro academicamente há alguns anos.

Nosso corpo responde às nossas emoções e hoje, analisando todo o percurso da pesquisa de campo, levando em conta todos os aspectos a ela ligados, consigo compreender mais claramente algumas situações, o que pode ser relevante na análise dos dados obtidos. Ter claro para mim que a pesquisa precisa registrar todos os aspectos possíveis, ou pelo menos aqueles que podem afetar de alguma forma o trabalho do pesquisador e os resultados da 
investigação, fez com que as teorias que li sobre "pesquisa qualitativa" tomassem um sentido real e vivo.

Apresento a seguir a escolha do campo, a pesquisa desenhada précampo, as situações de contato, os sujeitos de pesquisa e como se desenvolveu o trabalho de campo.

\section{1 \\ Delimitação do campo}

Como informado no capítulo de introdução desta tese, esta pesquisa desenhou-se como uma continuidade da pesquisa Mídia-Edu, realizada pelo Grupem. Interessava-me acompanhar mais de perto um processo de ensinoaprendizagem da produção audiovisual na escola. Como eu já havia realizado uma pesquisa em quatro escolas municipais e nesse processo havia conhecido vários professores que desenvolviam projetos com mídias, foi possível fazer contato com aqueles que promoviam oficinas de produção audiovisual. Ao término da pesquisa Mídia-Edu, no final de 2016, entrei em contato com cinco docentes que desenvolvem regularmente esse tipo de atividade nas escolas. Destes, dois responderam que poderiam receber-me em suas aulas durante 0 ano de 2017.

A partir dessa resposta, enviei uma proposta de pesquisa a esses professores, apresentando objetivos e metodologia, indicando as especificidades das turmas que gostaria de observar, e formalizando meu contato com eles. Desde o início delimitei que a pesquisa fosse realizada com alunos que não tivessem tido experiência anterior em oficinas de produção audiovisual na escola e que ocorresse em uma instituição onde não houvesse muitas atividades extraclasse voltadas para questões artísticas. Tal recorte foi delineado no início da pesquisa, com vista a atender seu objetivo central: descrever e analisar o processo de ensino-aprendizagem da linguagem audiovisual na escola, buscando identificar conhecimentos e habilidades desenvolvidas pelos estudantes. Supus que se os alunos participassem de outras oficinas, paralelas à de audiovisual, ficaria mais difícil atribuir as habilidades observadas à oficina de vídeo; além disso, se os alunos já tivessem participado dessa experiência anteriormente, eu não poderia avaliar se os "ganhos" observados estariam efetivamente relacionados a essa oficina. 
A partir desse recorte, um dos professores informou que todos os seus alunos das turmas de 2017 já haviam realizado atividades de produção de audiovisual e que a escola ofertava diversas oficinas além da sua - o que inviabilizava a proposta da pesquisa. O outro docente respondeu positivamente à minha solicitação, afirmando que teria cinco turmas de produção de vídeo de alunos iniciantes naquele ano. Com base nessas informações, formalizei com este professor a parceria para a pesquisa e após alguns dias ele informou que a direção da escola também estava de acordo com minhas visitas.

No início de 2017, entrei em contato com o professor, que ficou de me informar quando as turmas estariam formadas e quando iniciariam as oficinas. No início do ano letivo, ele estava visitando as turmas e convidando os alunos para a oficina. Pelo que relatou por e-mail, os alunos indicavam o interesse em participar e, após isso, ele organizaria as turmas para começar as aulas em março. Conforme combinado, aguardei o contato do professor para início das visitas.

\section{2}

\section{A pesquisa pensada: instrumentos}

Paralelamente à delimitação do campo, organizei e testei meus instrumentos de pesquisa. Como disse anteriormente, o estudo foi planejado dentro dos pressupostos da pesquisa qualitativa, uma vez que os dados seriam colhidos por meio de minha presença em campo, com visitas semanais à escola onde seriam realizadas observações das oficinas de produção audiovisual e entrevistas com alunos, professores e gestores. A escolha por esse tipo de pesquisa ocorreu porque, conforme André (2013, p. 97):

As abordagens qualitativas de pesquisa se fundamentam numa perspectiva que concebe o conhecimento como um processo socialmente construído pelos sujeitos nas suas interações cotidianas, enquanto atuam na realidade, transformando-a e sendo por ela transformados. Assim, o mundo do sujeito, os significados que atribui às suas experiências cotidianas, sua linguagem, suas produções culturais e suas formas de interações sociais constituem os núcleos centrais de preocupação dos pesquisadores.

Para compreender como se dá a experiência de produção audiovisual na escola, os conhecimentos e habilidades desenvolvidas nessa atividade, optei pela observação participante, com registro em diário de campo e com auxílio de audiogravações, quando as atividades ocorriam em sala de aula. De acordo com 
Valladares (2007), a observação participante é caracterizada pelo contato por um tempo relativamente longo com os sujeitos. Como a proposta da pesquisa foi observar se havia mudança nas atitudes dos alunos e na aprendizagem deles após a experiência da oficina de vídeo, era necessário acompanhar todo o processo durante o tempo em que ele ocorre, nesse caso, um ano letivo, conforme estabelecido pelo professor da oficina. Ao analisar as contribuições da obra "Street corner society", de William Foote Whyte, para a compreensão da observação participante como metodologia de pesquisa, Valladares (2007, p. 153-154) entende que:

O tempo é também um pré-requisito para os estudos que envolvem o comportamento e a ação de grupos: para se compreender a evolução do comportamento de pessoas e de grupos é necessário observá-los por um longo período e não num único momento.

$\mathrm{Na}$ escola observada, não são oferecidas outras oficinas para seu corpo discente além da oficina de vídeo. Tenho total consciência de que é impossível isolar do contexto o que observei nessa oficina e afirmar que os alunos aprenderam algo e mudaram suas atitudes por conta exclusivamente da experiência vivida com a produção de vídeos. Mas acredito que o registro rigoroso das habilidades que eles foram desenvolvendo ao longo do processo permite estabelecer relações com as atividades das quais eles participaram.

Nas pesquisas sobre esse tipo de evento (Machado, 2017; Pires, 2014) e nas experiências com que tive contato desde que iniciei os estudos sobre cinema e educação, os professores comentam sobre o entusiasmo dos alunos em participação do processo de produção de um vídeo e tais relatos constituíam minha bagagem, formando minhas lentes para essa observação na escola. É válido lembrar que o pesquisador nunca chega ao campo sem qualquer informação a respeito dos sujeitos e situações a observar, porém, como destaca Valladares (2007, p. 154):

O pesquisador não sabe de antemão onde está "aterrissando", caindo geralmente de "paraquedas" no território a ser pesquisado. Não é esperado pelo grupo, desconhecendo muitas vezes as teias de relações que marcam a hierarquia de poder e a estrutura social local. Equivoca-se ao pressupor que dispõe do controle da situação.

Embora tenha atuado em sala de aula de ensino fundamental por seis anos e tenha trabalhado com formação de professores do município do Rio de Janeiro e realizado diversas visitas a escolas da rede em pesquisas anteriores, aquela realidade não estava "dominada" por mim, como pesquisadora, dentro da situação em que eu me inseria naquele contexto. Acredito que minhas 
expectativas atrapalharam muito meu olhar sobre o campo, pelo menos nos primeiros meses, pois o que o campo me mostrava não estava "desenhado" como uma possibilidade previamente estudada nos bancos da academia. Junto aos meus pares, depois do aceno positivo do professor sobre minha entrada no campo, a pesquisa foi idealizada para cumprir os seguintes passos:

- observar todas as aulas da oficina de vídeo de 2017 - inicialmente três turmas de $8^{\circ}$ e $9^{\circ}$ anos, cada uma com 15 alunos, todas as quartasfeiras à tarde;

- registrar em diário de campo o que foi observado;

- gravar em áudio as aulas para auxiliar na análise depois da saída do campo;

- fotografar sempre que necessário as oficinas;

- aplicar, no início das aulas, uma atividade para compreender como os alunos viam a escola e as disciplinas e retomar essa atividade no encerramento das aulas, em uma entrevista individual com os alunos para discutir com eles se o seu olhar havia se modificado no decorrer do ano;

- produzir com cada um dos alunos um vídeo curto ou uma foto em que eles registrariam sua relação com a escola e/ou com a aprendizagem escolar;

- entrevistar professores e gestores da escola sobre a oficina - mais especificamente professores de língua portuguesa, matemática e ciências - a fim de verificar se eles percebiam alguma melhoria de aprendizagem dos alunos que participavam da oficina;

- registrar, regularmente, em protocolos previamente elaborados ${ }^{13}$ (Apêndice A), indícios ou indicadores de habilidades sociocognitivas que fossem desenvolvidas pelos participantes das oficinas, ao longo do processo de aprendizagem.

Foi no início do trabalho de campo que a problematização de Velho (1978, p. 39) sobre o que indica Da Matta (1978) a respeito de tornar familiar o exótico e vice-versa, passou a fazer sentido:

${ }^{13} \mathrm{O}$ formato, os objetivos e a estrutura desse protocolo de observação serão apresentados com maior detalhamento mais adiante. 
O que sempre vemos e encontramos pode ser familiar, mas não é necessariamente conhecido e o que não vemos e encontramos pode ser exótico mas, até certo ponto, conhecido. No entanto estamos sempre pressupondo familiaridades e exotismos como fontes de conhecimento ou desconhecimento, respectivamente.

Quando as turmas que comecei a observar passaram a não frequentar a oficina, como esperado, o que me era familiar passou a ser desconhecido. Precisei mudar de turmas no decorrer do ano letivo, tendo sempre o receio de que elas não chegariam ao final do processo. Os alunos que, em relatos de outras pesquisas sobre produção de filmes na escola, estão sempre envolvidos e presentes nas atividades, muitas vezes não pareciam radiantes e entusiasmados e nem o professor motivado, como eu supunha "conhecer" a partir dos relatos de experiências sobre o assunto.

Era frustrante sempre que a oficina era cancelada porque haveria uma reunião, paralisação de professores ou passeio no mesmo dia da aula, ou mesmo quando o professor precisava viajar ou faltar devido a outro trabalho que exercia fora daquela escola. Desde o primeiro dia de visita à escola (quando o professor chegou quase no final da aula), o campo se fez um desafio a ser vencido. Além disso, a receptividade do corpo docente em relação à pesquisa também não respondeu obviamente às minhas expectativas, uma vez que os professores não se mostraram disponíveis para a entrevista. Tais atitudes serviram de aprendizagem para mim, como pesquisadora, de que exótico e familiar estão mais relacionados do que imaginamos e de que a pesquisa sonhada, estudada e pensada, em todos os sentidos, para o cumprimento dos objetivos traçados, pode falhar. Porém, errar é normal e muitas falhas fogem ao domínio e às possibilidades de reorganização de que dispõe o pesquisador. De acordo com Valladares (2007, p. 154):

O pesquisador aprende com os erros que comete durante o trabalho de campo e deve tirar proveito deles, na medida em que os passos em falso fazem parte do aprendizado da pesquisa. Deve, assim, refletir sobre o porquê de uma recusa, o porquê de um desacerto, o porquê de um silêncio.

Outra característica da observação participante é a interação entre pesquisador e sujeitos, mas o pesquisador não é nem se tornará alguém da comunidade observada (Valladares, 2007). Algumas vezes, durante as filmagens, os alunos ou o professor indicavam que eu poderia participar de alguma cena do filme, atuando como professora, mas sempre recusei e eles compreendiam. A postura que assumi durante todo o ano de observação era o mais neutra possível, pois a observação solicitava de mim muita concentração, 
uma vez que além do diário de campo eu precisava registrar as habilidades nos protocolos e, por vezes, observei até quatro alunos por turma. Nesse contexto, não perdi de vista que minha presença durante as aulas poderia influenciar o andamento das oficinas e as atitudes dos sujeitos, conforme salienta Vianna (2003, p. 10):

Em observações em sala de aula, uma mudança que se opere no comportamento do professor e no dos alunos, pela presença do observador, pode comprometer todo o trabalho de pesquisa. [...] não é possível eliminar de todo a influência da presença do observador - trata-se de uma presença, e isso deve ser considerado nas análises.

Estive desde o início da oficina presente nas aulas, e acredito que isso tenha minimizado um pouco o estranhamento que os alunos poderiam ter de uma presença externa naquele ambiente durante o ano letivo. $O$ fato de não ter acompanhado desde o início a turma da manhã, pois passei a observá-la dois meses após o início da oficina, poderia ter influenciado o andamento das aulas, porém, percebi que os alunos não demonstraram qualquer inibição pela minha presença. Além disso, a sala onde acontecia a oficina era normalmente usada por pessoas de fora: quando não havia estudantes de outras turmas, utilizandose do espaço para estudar ou realizar trabalhos, havia professores ou servidores da escola e até pessoas externas, como técnicos ou funcionários enviados pela Secretariia Municipal de Educação (SME) para resolverem problemas nos computadores ou de conexão da internet. Assim, compreendo que os estudantes já estavam acostumados com pessoas de fora em suas aulas e que a minha presença não deve ter sido um fator que viesse a influenciar suas atitudes.

No diário de campo registrei como a turma estava, o clima da aula, as colocações mais relevantes, destacando o que achava importante entre as ocorrências daquele dia, pois contava com as gravações em áudio e, posteriormente, poderia recorrer a elas para retomar todos os momentos das discussões realizadas na oficina. O diário também serviu de guia, pois me ajudou a lembrar quais alunos já havia observado e os que ainda faltavam; nele registrei as visitas e os cancelamentos, indicando os motivos. Lancei mão desse instrumento dentro e fora da escola, registrando quando fazia contato com a diretora por WhatsApp ou perguntava ao professor se haveria ou não aula, se os alunos de outras turmas estavam indo ou não.

Nas observações das oficinas, preenchia regularmente o protocolo de registro de indicadores de habilidades sociocognitivas. Elaborado com auxílio do grupo de pesquisa, esse instrumento tinha como finalidade facilitar o registrar 
atitudes que indicassem ganhos no desenvolvimento dessas habilidades, pelos participantes das oficinas. O protocolo foi testado em uma oficina de vídeo, realizada em uma escola de Juiz de Fora por uma colega de doutorado, quando esta produzia um curta-metragem com os alunos da rede municipal (Machado, 2017). Após o teste, o instrumento foi modificado e sofreu ajustes também depois das primeiras observações realizadas por mim no trabalho de campo.

O objetivo era produzir material empírico que permitisse registrar, acompanhar e analisar possíveis mudanças de atitudes por parte dos alunos, decorrentes da experiência de produção audiovisual. Os aspectos abordados tratam de atitudes e habilidades em relação a: trabalho em equipe e realização/cumprimento/resolução de tarefa conjunta; empatia; planejamento de atividades/tarefas para médio e longo prazos; argumentação; organização de tarefas em diferentes etapas; transcodificação de linguagens; expressão de ideias; capacidade de escuta do outro; capacidade de transpor ideias para o texto (roteiro) e deste para as cenas, conforme pesquisas indicam como exercícios frequentes em atividades de produção audiovisual na escola (Menezes, Adrião \& Rios, 2017; Merlo, 2014; Santos, Barbosa \& Lazzareti, 2015; Sulzbach, 2014).

Autores entendem a produção de filmes como relevante para aprendizagem da linguagem cinematográfica e da estética, porém, as pesquisas sobre o tema sempre mencionam que esse tipo de atividade inclui, congrega e integra os envolvidos: "É uma feliz recorrência ouvir os estudantes relatarem, ao final do processo de uma oficina de realização audiovisual, que aprenderam a trabalhar em grupo." (Merlo, 2014, p. 293). Para alguns pesquisadores, as propostas de produção e recepção audiovisual na escola se constituem como um:

[...] disparador de processos de identidade individual e coletiva, tanto social, quanto ética e cultural. Isso coloca o estudante em contato com seu entorno, tempo e espaço, promovendo a integração e o sentimento de pertencimento e responsabilidade, ao almejar o desenvolvimento das capacidades típicas de uma postura ativa e consciente de indivíduo. (Santos, Barbosa \& Lazzareti, 2015, p. 34).

Como esta investigação busca entender de que maneira a produção audiovisual é vista e se estabelece na escola, seguindo o embasamento da pesquisa qualitativa, elaborei um roteiro de entrevista semiestruturada para conhecer o que os professores e a gestão da escola pensam sobre o tema e como percebem a produção de vídeos no cotidiano escolar. Sousa (2012, p. 85) define a tarefa de entrevistar como algo que: 
[...] exige uma abertura ao estranho como o navegador que é capaz de abandonar por instantes seus instrumentos de navegação produzindo assim uma deriva necessária no encontro do novo. Mas o que move alguém a correr este risco? Certamente um amor à verdade, uma coragem de furar a névoa do senso comum que nos seduz e paralisa, mas sobretudo um compromisso com seu tempo.

O roteiro da entrevista semiestruturada (Apêndice B) conta com sete questões sobre: interesse dos alunos pela oficina, mudança de comportamento e melhoria no desempenho dos alunos que participam da oficina nas disciplinas ministradas pelo professor entrevistado.

Depois de alguns meses no campo e com maior contato com os professores, solicitei à gestora da escola que me indicasse os professores que ministravam aulas no segundo segmento do ensino fundamental para que eu Ihes solicitasse a entrevista. Entrei em contato com os indicados, mas diante da pouca disponibilidade dos docentes para isso, propus que eles respondessem as questões por e-mail. Assim, por várias vezes, presencialmente e por e-mail, tentei contatar os professores, mas poucos se mostraram disponíveis. A professora de matemática aceitou enviar suas respostas por e-mail e consegui entrevistar, entre os que tinham contato com os alunos que estava observando, apenas o professor de educação física. Continuei até o fim das visitas tentando a entrevista com os professores de língua portuguesa e de ciências, mas não obtive sucesso.

Há na escola uma funcionária que sempre era apontada pelos professores como alguém importante para eu entrevistar, pois foi aluna da escola e havia feito essa oficina, sendo uma das personagens principais de um filme feito há alguns anos na oficina de vídeo. Ela concordou em ser entrevistada e também consegui entrevistar um de seus colegas de oficina, que esteve na escola e se mostrou bastante disponível para contribuir com a pesquisa. Procurei também outros profissionais da escola que pudessem contribuir com a pesquisa e entrevistei duas professoras: uma delas leciona no fundamental I e, em anos anteriores, havia sido professora de todos os alunos que eu estava acompanhando na oficina deste ano. Como já estava na escola há muitos anos, foi uma excelente informante sobre como essa experiência influenciou na rotina dessa escola. A outra entrevistada é professora readaptada, mas foi professora de vários alunos e, assim como sua colega, acompanhou o decorrer dessa oficina na escola e a influência desta para o desenvolvimento de alguns alunos especiais. 
Quando lembro que a maior parte dos professores da escola pesquisada preferiu não conceder entrevistas para a pesquisa, o verbete "entrevistar", de Sousa (2012) toma novos contornos e pode ser visto como uma situação em que pesquisador e sujeito estariam nesse "mesmo barco" à deriva, indo juntos ao encontro de algo novo ou desconhecido. De acordo com Duarte (2004, p. 220):

Quando realizamos uma entrevista, atuamos como mediadores para o sujeito apreender sua própria situação de outro ângulo, conduzimos o outro a se voltar sobre si próprio; incitamo-lo a procurar relações e a organizá-las. Fornecendo-nos matéria-prima para nossas pesquisas, nossos informantes estão também refletindo sobre suas próprias vidas e dando um novo sentido a elas. Avaliando seu meio social, ele estará se autoavaliando, se autoafirmando perante sua comunidade e perante a sociedade, legitimando-se como interlocutor e refletindo sobre questões em torno das quais talvez não se detivesse em outras circunstâncias.

Não tenho elementos para justificar a falta de interesse deles em conceder a entrevista, mas posso levantar algumas hipóteses sobre a recusa em "entrar nesse barco comigo", indo ao encontro do desconhecido. É possível que os professores do ensino fundamental II não estivessem interessados nesse tipo de reflexão, achando que não teriam nada de relevante a dizer sobre a oficina, talvez por pensarem que não tinham informações importantes para minha pesquisa, embora ao solicitar a participação deles, eu sempre explicasse os fins da entrevista. Boa parte dos professores tem mestrado e doutorado, portanto, eu esperei uma maior disponibilidade deles nesse sentido. Além disso, eles sempre se mostraram muito próximos de mim durante o almoço no refeitório ou nos intervalos das aulas. Essa foi mais uma expectativa que criei baseada em autores que indicam como foi fácil e natural conseguir informantes para sua investigação.

Além de observar os alunos nas atividades propostas para a oficina, solicitei ao professor alguns momentos no início e no final da oficina para realizar uma atividade elaborada antes da entrada no campo para que eu tivesse dados sobre como os alunos se relacionavam com a escola e com as disciplinas obrigatórias. A proposta trazia emoticons ${ }^{14}$ do WhatsApp para que os alunos indicassem qual deles representava sua relação com as diversas disciplinas escolares e com a própria escola.

\footnotetext{
14 Termo criado a partir da junção das palavras inglesas emoticon (emoção) + icon (ícone), o emoticon é uma sequência de caracteres tipográficos ou uma imagem que se apresenta como ícones ilustrativos de uma expressão facial para traduzir ou transmitir o estado psicológico/emotivo de quem os utiliza. Ver mais informações em: https://pt.wikipedia.org/wiki/Emoticon. Acesso em 7 jan. 2019.
} 
Os alunos responderam ligando os emoticons com traços até os nomes das disciplinas ou numerando-os e criando legendas. Essa atividade teria um segundo momento, que seria a produção de um vídeo ou uma foto cuja proposta era que o estudante apresentasse como era sua relação com a escola e/ou com a aprendizagem. Todos os alunos escolheram fazer fotos. Os alunos das turmas de $8^{\circ}$ e $9^{\circ}$ anos ficaram de fazer esses registros em casa e publicar no grupo do Facebook, criado pelo professor da oficina. Porém, eles não cumpriram o combinado e, sempre que podia, cobrava deles essa produção. Como percebi que eles não iriam enviar, resolvi oferecer meu celular para que eles fizessem o registro na escola durante a oficina de vídeo. Quando fiz a atividade com os alunos do $7^{\circ}$ ano, já propus que fizessem o registro conforme me entregavam a atividade dos emoticons. Quando terminavam o registro, eles me mostravam a foto e justificavam suas escolhas - essas conversas foram gravadas em áudio.

Inicialmente, essa tarefa foi pensada para uma possível comparação entre o tipo de relação que os alunos estabeleciam com as disciplinas e a escola antes e depois da oficina. Porém, no final do ano, o professor e os alunos se apressaram com as filmagens e ficaram bastante envolvidos com provas e atividades de final de ano. Todos os encontros serviam para adiantar o máximo de cenas, pois em muitos momentos os protagonistas do filme faltaram e isso atrasou a finalização do filme. Para fechar a proposta da atividade dos emoticons e das fotos, a previsão era realizar uma entrevista individual com os alunos no final do ano e observar a percepção deles em relação às disciplinas, analisando junto com cada um sua atividade de emoticons e a foto produzida. Pelos motivos indicados, não foi possível realizar algo tão direcionado e individual.

Sendo assim, no mês de novembro, com as filmagens ainda por terminar, já previ que não haveria tempo para entrevistar cada um dos alunos. Então, elaborei um roteiro de questões sobre habilidades desenvolvidas nas oficinas, com base no protocolo usado para observação dos alunos. Junto com o Grupem, pensamos em uma abordagem que envolvesse os alunos, pois eu só teria uma oportunidade para essa entrevista e caso os alunos não se sentissem à vontade para falar, não contaria sequer com essa entrevista entre os dados da pesquisa.

Inspirados na metodologia utilizada por Galera, Matsumoto e Poveda (2016) sobre uso de mídias por crianças de Madri, elaboramos cartões que pudessem ser usados como disparadores de respostas para as perguntas. Uma aluna de graduação e bolsista de iniciação científica do Grupem, Carolina 
Morales, ficou responsável pelo desenho da maior parte dos cartões, e outras imagens foram retiradas da internet.

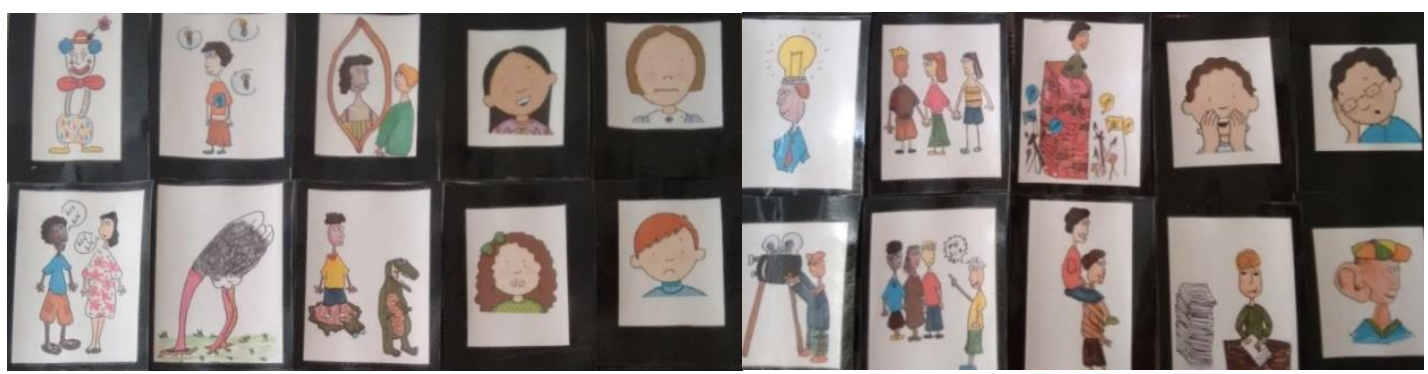

Figura 3 - Cartões para entrevista final

Fonte: Arquivos da pesquisa.

$\mathrm{Na}$ penúltima aula, conversei com os alunos sobre a possibilidade de entrevista em grupo no encontro seguinte e eles se dispuseram a participar. O dia previsto para a entrevista também foi o último da oficina. Nesse momento, os alunos e o professor demonstraram o quanto estavam interessados em contribuir com a pesquisa. Durante toda a manhã de um dia quente de dezembro, eles filmaram a última cena do filme na casa de uma das alunas, que se passava em uma festa surpresa preparada para a personagem principal. A turma organizou lanches para aproveitar e festejar o final da oficina, com uma festa "de verdade". Nesse mesmo dia, eles haviam recebido pelo WhatsApp a informação de que todos haviam "passado de ano" e estavam muito eufóricos com a notícia.

Até o último momento, pensei que a entrevista não aconteceria, devido à euforia deles com o fim da oficina, com as notas e o término do ano letivo. Porém, depois da "festinha", fomos juntos, a pé, até a escola, que ficava a $2 \mathrm{~km}$ de distância de onde nos encontrávamos. Chegando lá, depois de checarem os nomes na lista de aprovados, todos se dirigiram até a sala de leitura e participaram da entrevista, sem que eu tivesse que solicitar a presença de ninguém. Contei com o valioso auxílio do professor da oficina nesse momento, que filmou e gravou a entrevista com seu celular e gravador de áudio, usados também para a filmagem do vídeo dos alunos.

A entrevista durou 24 min e ocorreu paralelamente a uma atividade realizada pela professora da sala de leitura com outros alunos. Embora houvesse um barulho constante por conta da conversa desse outro grupo, conseguimos nos concentrar na entrevista e tudo correu conforme planejado. Essa entrevista não passou por pré-teste, pois não houve tempo suficiente para isso (Apêndice $B$ ).

Assim, como material empírico a pesquisa conto com: 
- registro de 32 diários de campo em 24 visitas;

- 30 arquivos de áudio com cerca de 24 horas de gravações das oficinas;

- 62 protocolos preenchidos;

- 5 entrevistas gravadas em aúdio com os professores e a diretora da escola, sendo uma delas com o professor da oficina. Uma professora respondeu por e-mail. Ao todo, são quase 2 horas de áudio;

- 2 entrevistas com ex-alunos da oficina, que somam pouco mais de 30 minutos;

- 139 fotos e 21 vídeos da escola e da oficina ${ }^{15}$, alguns postados nos grupos criados pelo professor no Facebook das turmas observadas;

- 1 entrevista com cartões, realizada com os alunos e gravada em vídeo de 24 minutos;

- atividade com emoticons realizada pelos alunos da oficina e digitalizada: 10 da turma final e 18 de alunos desistentes;

- fotos produzidas pelos alunos (17 da turma desistente e 8 da turma final) sobre sua relação com a escola e/ou com a aprendizagem, com a respectiva explicação da foto, gravada em áudios curtos.

As visitas ao campo iniciaram em março de 2017, encerrando-se na primeira semana de dezembro do mesmo ano. Ao todo, foram 24 visitas à escola, porém, nem todos os dias em que estive lá, houve registro no protocolo de acompanhamento dos alunos nas atividades, porém, todas as observações foram descritas em diário de campo. O quantitativo de visitas, de registros no diário de campo e de protocolos preenchidos está resumido no quadro a seguir:

\footnotetext{
${ }^{15}$ Cedi a maior parte desse material ao professor da oficina, que o utilizou para o relatório anual de suas atividades na oficina junto à CRE.
} 


\begin{tabular}{|c|c|c|c|c|}
\hline Visitas & Data/ dia & $\begin{array}{l}\text { Qt de } \\
\text { turmas }\end{array}$ & Turnos & Protocolo \\
\hline 1 & 8 mar. / quarta & 1 & tarde & Sem registro \\
\hline 2 & 3 maio / quarta & 2 & tarde & $\begin{array}{l}\text { Turma 1: } 4 \text { alunos / } \\
\text { Turma 2: } 2 \text { alunos }\end{array}$ \\
\hline 3 & 16 maio / terça & 2 & manhã & $\begin{array}{l}2 \text { alunos de cada } \\
\text { turma }\end{array}$ \\
\hline 4 & 17 maio / quarta & 2 & tarde & $\begin{array}{l}\text { Turma 1: } 4 \text { alunos / } \\
\text { Turma 2: } 2 \text { alunos }\end{array}$ \\
\hline 5 & 24 maio / quarta & 1 & tarde & Sem registro \\
\hline 6 & 30 maio/ terça & 2 & manhã & $\begin{array}{l}2 \text { alunos de cada } \\
\text { turma }\end{array}$ \\
\hline 7 & 13 jun. / terça & 2 & manhã & $\begin{array}{l}2 \text { alunos de cada } \\
\text { turma }\end{array}$ \\
\hline 8 & 14 jun. / quarta & 1 & tarde & $\begin{array}{l}\text { Sem observação nem } \\
\text { registro }\end{array}$ \\
\hline 9 & 20 jun./ terça & 2 & manhã & $\begin{array}{l}2 \text { alunos de cada } \\
\text { turma }\end{array}$ \\
\hline 10 & 27 jun. / terça & 2 & manhã & $\begin{array}{l}\text { Turma 1: } 4 \text { alunos / } \\
\text { Turma 2: } 4 \text { alunos }\end{array}$ \\
\hline 11 & 4 jul./ terça & 2 & manhã & $\begin{array}{l}\text { Turma 1: } 3 \text { alunos / } \\
\text { Turma 2: } 3 \text { alunos }\end{array}$ \\
\hline 12 & 13 jul./ quinta & - & tarde & Sem registro \\
\hline 13 & 5 set./ terça & final & manhã & 2 alunos \\
\hline 14 & 12 set./ terça & final & manhã & 2 alunos \\
\hline 15 & 19 set./ terça & final & manhã & Sem registro \\
\hline 16 & 26 set./ terça & final & manhã & Sem registro \\
\hline 17 & 17 out./ terça & final & manhã & 4 alunos \\
\hline 18 & 24 out./ terça & final & manhã & 4 alunos \\
\hline 19 & 7 nov./ terça & final & manhã & Sem registro \\
\hline 20 & 14 nov./ terça & final & manhã & Sem registro \\
\hline 21 & $21 \mathrm{nov} . /$ terça & final & manhã & 4 alunos \\
\hline 22 & 28 nov./terça & final & manhã & 4 alunos \\
\hline 23 & $5 \mathrm{dez} . /$ terça & final & manhã & Sem registro \\
\hline Totais & Diários & 32 & Protocolos & 62 \\
\hline
\end{tabular}

Quadro 1 - Especificações das visitas à escola Fonte: Elaboração própria.

Com todas as mudanças nos planos da pesquisa, e a partir dos exames de qualificação, foi necessário modificar os objetivos da pesquisa para olhar de maneira mais objetiva os dados de que eu dispunha para análise, buscando ser fiel ao que a observação da oficina me mostrou durante todo o ano na escola. A desistência dos alunos, a maneira como o professor propôs as atividades, a impossibilidade de entrevistar os demais professores, enfim, que sentido atribuir aos movimentos de todos os sujeitos, incluindo eu, em relação à produção audiovisual na escola pesquisada? Onde ficam os interesses pelo "cinema na escola" como uma "proposta inovadora", que envolve os alunos (Menezes, Adrião \& Rios, 2017; Husbye, 2013; Sulzbach, 2014), ensina os participantes de maneira diferente (Miranda, 2015; Pimentel, 2013; Pires, 2014), e muda um pouco a rotina na escola, ao olharmos de perto para essa experiência? 
A análise dos dados foi realizada articulando procedimentos de descrição densa com base em Geertz (2008) e análise de conteúdo (Bardin, 1977). Para organização dos documentos, utilizei o software Atlas.ti. para criação de códigos no processo de composição de categorias e eixos de análise dos protocolos de observação das atitudes e habilidades desenvolvidas pelos alunos, em resposta à pedagogia apresentada pelo professor. Os códigos foram criados a partir das atitudes indicadas no protocolo de observação e os eixos de análise se concentraram na pedagogia do professor em relação com as habilidades desenvolvidas pelos alunos em cada atividade proposta na oficina e, em seguida, como uma aprendizagem do grupo.

A seguir, apresento com maiores detalhes a escola onde realizei a pesquisa, as situações de contato com o campo e os sujeitos.

\section{3 \\ Escola da pesquisa}

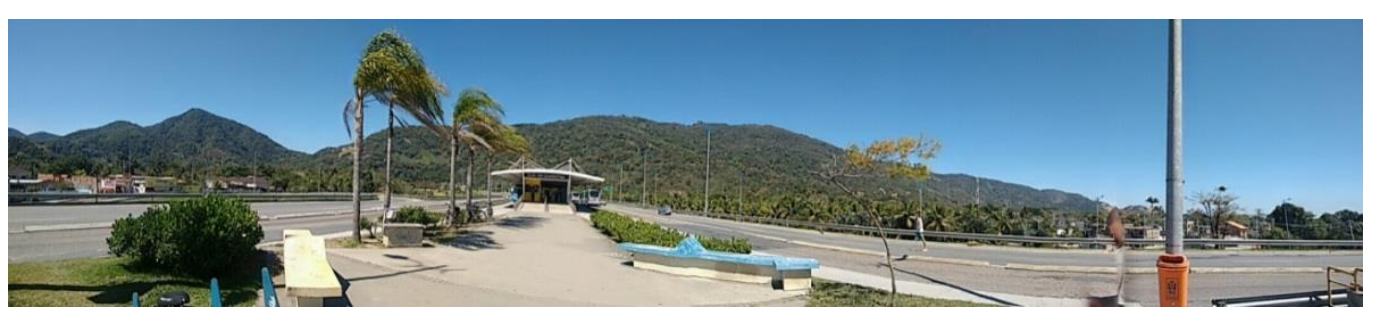

Figura 4 - Estação do BRT no bairro da escola pesquisada

Fonte: Arquivos da pesquisa.

A escola está localizada na Zona Oeste do município do Rio de Janeiro, em um bairro praticamente rural, que conta com uma estação do BRT, mas fica distante de centros culturais, shoppings e centros comerciais. A unidade faz parte da 10 ${ }^{\text {a }}$ Coordenadoria Regional de Educação (CRE) - Santa Cruz e atende cerca de 700 alunos, com corpo docente de 35 professores. Os alunos dessa escola contam com ônibus escolar da prefeitura para seu deslocamento durante os horários de abertura e fechamento dos turnos.

Essa unidade atende alunos do $1^{\circ}$ e $2^{\circ}$ segmento do ensino fundamental em dois turnos. A estrutura é antiga e algumas salas não possuem paredes completas, como a sala dos professores, por exemplo. A escola conta com uma sala que congrega espaços para direção, coordenação e secretaria, além de dois banheiros e uma pequena cozinha para funcionários; a maioria das salas de aula é climatizada; biblioteca e sala de leitura dividem o mesmo espaço, também 
muito pequeno para a quantidade de alunos atendidos; laboratório de informática; dois banheiros para alunos; cozinha e refeitório com capacidade para 60 pessoas. Há dois pátios descobertos: um na entrada e outro nos fundos da escola, com traves de futebol e cestas de basquete, mas sem piso adequado para prática de esportes.

A oficina ocorre em contraturno na sala de informática, climatizada, que conta com cinco computadores de mesa ligados à internet, mas nem todos funcionam, pois sempre um equipamento periférico está com defeito. As janelas desta sala estão voltadas para o pátio dos fundos, usado nos recreios e aulas de educação física, portanto, as aulas sempre têm a interferência de ruídos externos. Esse laboratório é usado também como uma espécie de depósito de objetos sem uso (condicionadores de ar, impressoras e cadeiras) ou de arrecadações feitas pela escolas para algumas campanhas. É muito usado para reuniões e palestras dadas por pessoas enviadas pela CRE ou SME. Por diversas vezes, a oficina foi cancelada ou terminou antes do horário previsto porque essa sala seria usada para outro fim e não havia outra sala disponível para a oficina.

A sala tem como decoração os pôsteres dos filmes já realizados em anos anteriores pelos alunos dessa escola, nas oficinas de vídeo. Uma frase muito conhecida no campo de cinema e educação, de Alain Bergala, está colada em um dos quadros de aviso: "Se o encontro com o cinema como arte não ocorrer na escola, há muitas crianças para as quais ele corre o risco de não ocorrer em lugar nenhum."

Uma professora e a gestora mencionaram em entrevista à pesquisa que essa escola se constitui como o espaço de acesso à cultura para a comunidade por ela atendida. Algumas vezes presenciei festas de datas comemorativas, como festa junina e halloween, por exemplo, decoradas com as produções dos alunos do fundamental I. Uma vez presenciei a escola se organizando para a apresentação de uma peça teatral. As únicas atividades em contraturno da escola são aulas de reforço na sala de leitura e a oficina de vídeo. 


\section{4 \\ Situação de contato}

O contato inicial com a escola e seus sujeitos foi feito a partir do professor da oficina ${ }^{16}$. No primeiro dia na escola, ele me apresentou suas turmas e já cheguei observando a oficina. Não houve uma apresentação formal de minha pessoa à direção da escola nem aos demais professores. Essa relação foi se construindo aos poucos, conforme eu tinha contato com os profissionais e me apresentava para eles. No início, esperei que o professor me apresentasse à direção da escola, mas isso não aconteceu e, após alguns dias, eu consegui descobrir quem era a diretora e me apresentei a ela, que me acolheu com um sorriso, demonstrando saber quem eu era e o que estava fazendo na escola. Com o passar das semanas, ia me fazendo conhecida dos alunos, professores e funcionários. Com estes últimos as conversas ocorriam inclusive na hora do almoço, pois eles sempre me acolheram com muito carinho, como se eu fizesse parte da escola.

O contato com os alunos das oficinas ocorreu sem dificuldades. Sempre nas primeiras visitas o professor me apresentava como pesquisadora e pedia pra eu falar pra eles o que estava fazendo ali. Eles perguntavam o que era um "doutorado", pra que servia e eu explicava, destacando para que observaria as oficinas, e informando que anotaria e gravaria os encontros em áudio, sempre que necessário; também perguntei a eles se poderia tirar algumas fotos e filmar a turma de vez em quando, ao que eles permitiram. Garanti, desde o primeiro contato, que não iria divulgar suas imagens e que preservaria sempre a identidade deles quando fosse escrever a tese, ao que muitos respondiam: "Ah, tia, pode usar meu nome mesmo!"

Todas as vezes que precisei solicitar aos alunos que respondessem alguma atividade que propunha, ou ouvissem minha explicação sobre o termo de consentimento (Apêndice C) e como deveriam apresentá-lo aos pais, eles atenderam e participaram das conversas e tarefas, inclusive da entrevista ao término da pesquisa.

A oficina de 2017 foi oferecida para cinco turmas de alunos iniciantes: três turmas de $8^{\circ}$ e $9^{\circ}$ anos às quartas à tarde e duas turmas de $7^{\circ}$ ano às terças pela manhã, cada uma com uma média de 15 alunos. Ao questionar ao

${ }^{16}$ Como esta pesquisa faz parte de uma pesquisa maior (Mídia-Edu), conforme já apresentei anteriormente, as autorizações para minhas visitas à escola já estavam garantidas desde a liberação dada pela SME e a CRE para a pesquisa-mãe. 
professor quais eram as turmas que eu poderia acompanhar, ele informou que geralmente as de alunos de $8^{\circ}$ e $9^{\circ}$ anos é que costumavam "vingar". Outro fator que ele destacou era que geralmente havia uma diminuição da quantidade de alunos nas turmas e logicamente haveria menos desistência de três turmas do que de duas. Assim, escolhi as três turmas de quarta à tarde.

E aqui iniciaram os poréns desta pesquisa. Desde o início de minha ida à escola, as três turmas de quarta não chegaram a frequentar a oficina. Cada turma deveria estar na escola às 13h, $14 \mathrm{~h} 30$ e 16h, porém, apenas alguns alunos do primeiro e do segundo horário estiveram presentes nos primeiros dias. A terceira turma nunca veio. Com o passar do tempo, o professor juntou os alunos em uma turma só, mas a turma não chegou sequer ao final do primeiro semestre. Pela falta de sujeitos a observar, passei a ir à escola também às terças-feiras pela manhã para acompanhar as duas turmas de $7^{\circ}$ ano que estavam frequentando, com uma média de 10 alunos cada. Pouco antes do final do primeiro semestre a turma de quarta já não mais existia e eu estava indo à escola apenas às terças. No retorno das férias, uma das turmas desistiu de continuar a oficina, assim como alguns alunos da outra turma. Os remanescentes formaram uma nova turma que chegou com nove alunos ao término do ano e conseguiu finalizar as gravações. Foi com esses alunos que realizei a entrevista final, mais especificamente: 5 meninos (Vítor, Leo, João, Igor e Marcio) e 5 meninas (Sueli, Vanir, Carla, Keyla e Vita).

A vontade de mostrar para todos como é necessário o cinema na escola aumentava ainda mais o meu desespero ao ver dia após dia os estudantes abandonando a oficina ou ao deparar-me com uma metodologia distante daquilo que eu considerava padrão-ouro para a implementação de uma experiência inovadora com a arte através da produção audiovisual. Isso se tornava pior pelo fato de a escola escolhida para a observação ficar a três horas de distância de ônibus da minha casa. Percebi que isso também é relevante no trabalho de pesquisa. Preciso confessar que, por vezes, era muito difícil ir à escola, pois por várias vezes dei "viagens perdidas". A volta era ainda mais cansativa, pois fazia um trajeto de uma hora e meia de $\mathrm{BRT}^{17}$ e nem sempre havia um assento livre para que eu pudesse aproveitar o deslocamento e fazer anotações sobre o que fora observado na escola. Depois do BRT, pegava um ônibus que atravessava o Alto da Boa Vista e, nessa experiência semanal, passei a dar um valor imenso à

\footnotetext{
17 Os ônibus do BRT trafegam em pista exclusiva e têm três composições articuladas para cumprir o objetivo de transportar um grande número de pessoas em um tempo menor, pois não enfrenta congestionamentos como os demais carros da via.
} 
minha própria vida, pois os motoristas de ônibus raramente tinham ideia de segurança no trânsito, desrespeitando a velocidade; e as pessoas que reclamavam eram vistas com maus olhos e até "xingadas" pelo motorista e por outros passageiros que queriam chegar logo ao seu destino.

Esses relatos não apareceram em meus textos de qualificação por pensar que poderiam dar a impressão de uma autopiedade, mas refleti melhor sobre isso, e decidi apresentar como se constituiu todo o trabalho de campo.

Para isso, creio ser relevante indicar como eu entrava e saía da escola e, como me inspirou Da Matta (1978), o sentimento de não querer ir até o campo poderia estar ligado não apenas à escola e seus sujeitos, por eles não me darem a pesquisa que eu havia sonhado. Essa não vontade de retornar poderia também estar relacionada ao meu deslocamento de volta para casa.

Conforme minhas expectativas iam sendo quebradas com os fatos até aqui relatados, ainda no início do trabalho de campo já me preocupava com o que pensava ser a "falta de dados" para a pesquisa. Assim, em maio/2017, resolvi fazer contato com duas professoras que realizavam produção de vídeo na escola, indicadas pelo professor que eu já estava acompanhando. Enviei e-mail com a proposta de pesquisa. Uma delas nunca chegou a responder, embora ela mesma tivesse me passado seu e-mail por WhatsApp; a outra disse que não poderia me receber na sua escola, porque ela estava fazendo mestrado e sua orientadora lhe disse para não aceitar outra pesquisadora em sua turma. Depois dessa tentativa, deixei de procurar outras oficinas e focar minha atenção nesta que já havia me recebido com tamanha atenção.

\section{5 \\ Sujeitos da pesquisa}

\section{* Os alunos}

A partir do que apresentei até aqui sobre o campo, hoje entendo que o curso dos acontecimentos é que escolheu "meus sujeitos". O que escolhi foi observar oficinas de vídeos com alunos que não tivessem passado ainda por esse tipo de experiência. Talvez a falta do controle sobre esses aspectos e um "plano B" viável naquele momento tenha sido o fator que mais me desestabilizou diante do trabalho de campo e, mais ainda, diante dos dados a serem 
analisados. O primeiro "plano B" foi passar a acompanhar as turmas de $7^{\circ}$ ano quando as de $8^{\circ}$ e $9^{\circ}$ anos já estavam com uma baixa frequência. Durante dois meses, visitei a escola às terças e quartas, antecipando-me ao fechamento das turmas de quarta, como aconteceu. Em relação à atividade de emoticons e a produção da foto sobre a escola/aprendizagem, aplicadas no início da observação, o "plano B" ficou por conta do uso desse material na escrita da tese. Portanto, usarei as atividades para apresentá-los, assim, não apago os rastros do que foi feito na pesquisa e retomo aquilo que parecia ter se tornado restos.

Os alunos que observei eram moradores do mesmo bairro em que fica a escola e chegavam até lá no ônibus disponibilizado pela prefeitura ou a pé. Como se trata de um bairro rural, a maior parte dos alunos mora um pouco distante da escola. A rua da escola possuía muitos sítios, onde eram vendidas plantas, ou onde funcionavam madeireiras, havendo poucas casas ali perto. Várias vezes presenciei a chegada ou saída dos estudantes nos ônibus. Apenas um aluno da oficina, Leo, ia para casa de carro com o pai. A maior parte da turma era pontual e alguns destoavam nesse sentido, como Leo, que vinha com o pai, ou Vanir, que morava mais distante da escola e vinha de BRT.

Os participantes da oficina lanchavam a comida oferecida na escola e, por várias vezes, percebi um aluno em especial, que todos os dias corria quando tocava o sinal para o lanche: João sempre perguntava o que era o lanche, ou se encarregava de passar na cozinha para saber o prato do dia e avisar aos demais, mesmo que estes não tivessem solicitado a informação. Isso indica que, para ele, a merenda era algo bastante relevante, o que ficou mais claro durante as observações das aulas, pois no início da oficina ele geralmente estava sonolento e disperso, ficando mais participativo após a hora do intervalo e merenda. João é um aluno bastante ativo e, no início, eu atribuí sua falta de participação ao fato da aula começar cedo e ele possivelmente ter ficado acordado até tarde na noite anterior. Diversas vezes ele entrava na sala dizendo qual seria o prato daquele dia e apenas Leo não se interessava pela informação, pois era um dos poucos, talvez o único, que não comia a merenda escolar.

No começo do ano, a proposta da oficina era não ter intervalo para o lanche, pois as aulas duravam uma hora e meia. Como os alunos passaram a pedir para lanchar ao sinal do intervalo, o professor liberava apenas quem queria merendar, solicitando que eles voltassem rapidamente. Pouco tempo depois, a diretora da escola solicitou ao professor que passasse a liberar todos os alunos durante o intervalo, pois, como ela mesma indicou, muitos vinham para a escola 
sem café da manhã ou sem almoço. O professor atendeu ao pedido prontamente, mas combinou com os alunos de chegarem mais cedo à aula para não perderem o horário dispensado ao lanche. Os alunos concordaram e a oficina seguiu dessa maneira até o final do ano.

Os alunos usavam uniforme escolar, mas alguns tinham casacos, mochilas, acessórios e tênis mais novos e aprentemente de melhor qualidade do que a maioria. Poucos participantes tinham celulares, mas os que tinham contavam com acesso à rede de internet móvel e sempre compartilhavam o aparelho com os colegas.

A infrequência dos alunos era grande, o que complicou bastante a identificação de recorrências no registro do protocolo, pois quando precisava observar determinado aluno, naquele dia ele havia faltado, e só estavam presentes alunos que já tinham protocolos registrados recentemente. A proposta previamente pensada para o registro no protocolo era acompanhar cada aluno em uma oficina pelo menos uma vez por mês. A recorrente ausência de alguns alunos acarretou problemas para as gravações do filme, pois quando os que faltavam eram relevantes para as filmagens, a oficina era cancelada. Nesses casos, não havia um contato entre o professor e os alunos, quando possível, para que estes avisassem que faltariam e a aula fosse, então, cancelada, evitando que os demais alunos, além do professor e eu, nos deslocássemos em vão até a escola. Isso aconteceu várias vezes. Ao todo, 10 alunos participaram até o final da oficina, conforme apresento a seguir.

Vanir $^{18}$ é uma aluna com quem tive pouco contato no início das oficinas. Ela não estava presente nos dias em que comecei a observar sua turma, portanto, só passei a ter mais contato com ela no segundo semestre, quando iniciaram as filmagens. Ela fez a personagem principal do filme e sua presença era imprescindível para que as filmagens ocorressem. Mesmo assim, faltou algumas vezes ou chegou atrasada, pois morava um pouco distante da escola. Vanir é uma garota atuante e sempre dava suas opiniões durante a oficina; vinha com o texto decorado e atuava com bastante concentração.

\footnotetext{
18 Uso nomes fictícios para me referir a todos os sujeitos da pesquisa.
} 


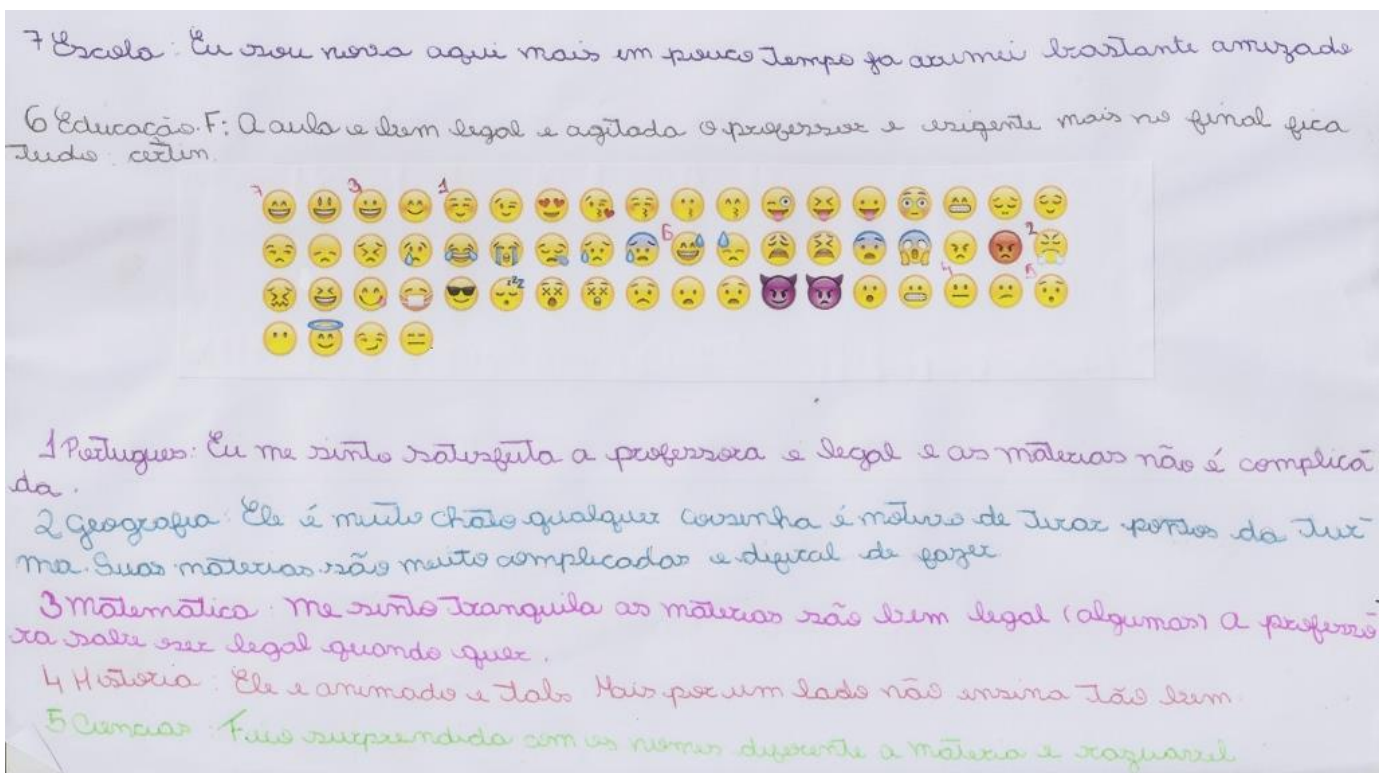

Figura 5 - Relação com as disciplinas e a escola - Vanir Fonte: Arquivos da pesquisa.

O material produzido por Vanir indica que ela é uma aluna nova nessa escola, mas a partir do que escreveu na atividade e do que percebi nas observações, ela fez amigos rapidamente. Dos emoticons que ela indicou para as sete matérias descritas, apenas dois deles podem ser relacionados a sentimentos ruins, como chateação ou falta de concordância com algo, no caso, com o desempenho do professor para ensinar história, segundo sua avaliação.

Keyla é uma garota alta, bem maior do que seus colegas. Ela estava sempre presente e participou mais da escolha da história e escrita do roteiro do que das filmagens. Ela não gostava de aparecer nas fotos que o professor ou eu tirávamos da turma. Participou das filmagens fazendo figuração e não se interessou por nenhum dos equipamentos. Mesmo quando não fazia parte da cena que estavam filmando, ela ficava por perto. No final do ano, ela comentou comigo que queria ter feito um personagem que aparecesse mais na história. Eu disse que ela poderia ter participado dos testes e que teria conseguido, mas ela respondeu que: "Os meninos é que escolhiam quem ia fazer os personagens" dando a entender que ela não seria escolhida. 


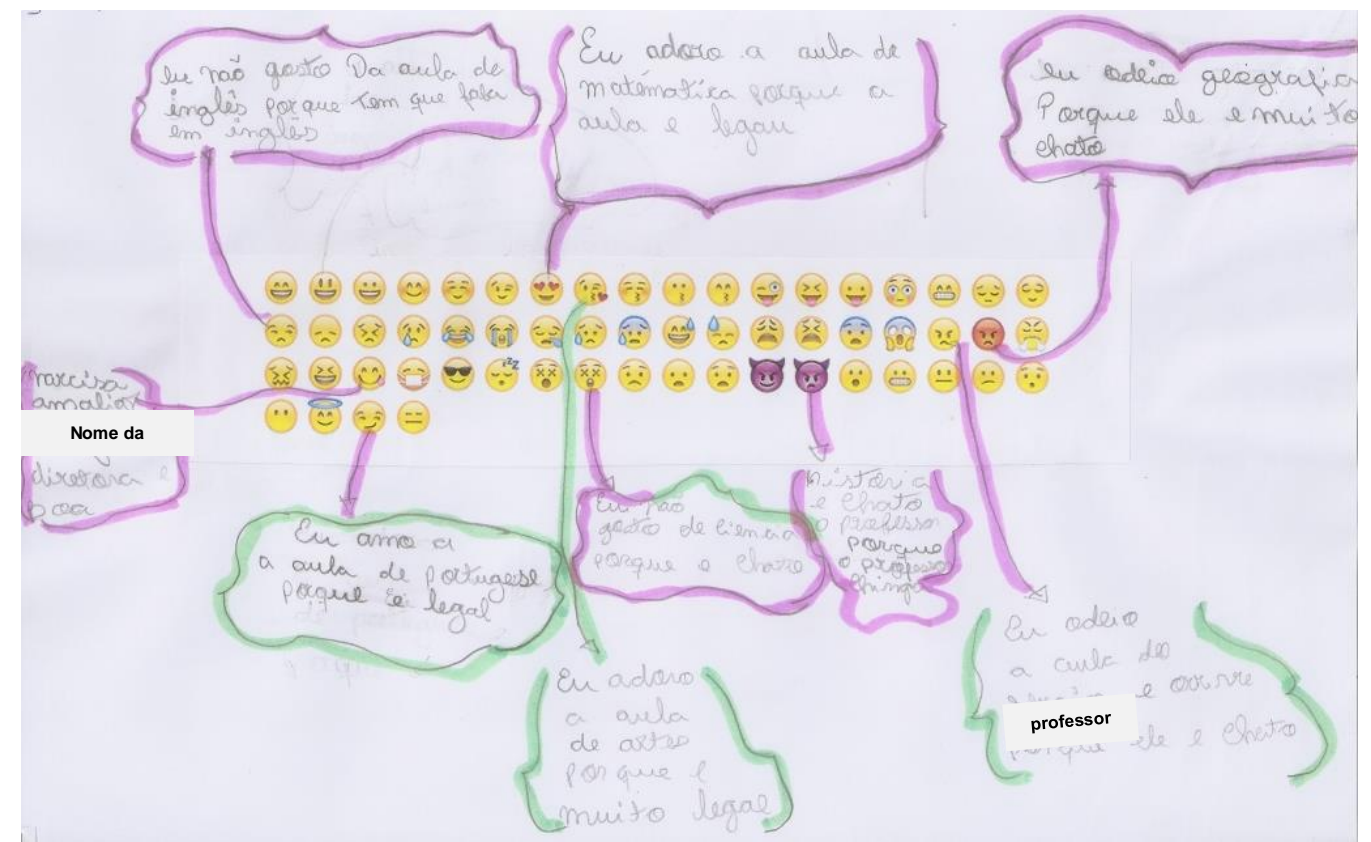

Figura 6 - Relação com as disciplinas e a escola - Keyla Fonte: Arquivos da pesquisa.

De acordo com sua atividade, Keyla gosta da escola e das aulas de português e matemática. Seu "gostar" parece estar sempre relacionado ao professor da disciplina, uma vez que ela justifica sua resposta, dizendo que odeia ou não gosta porque o professor é chato ou porque "chinga". A relação dela com a escola é classificada como boa pela mesma perspectiva, ao dizer que a "diretora é boa".

Igor participou pouco da escrita do roteiro, pois preferia ficar brincando e conversando com os colegas, enquanto os outros escreviam. $O$ professor comentou que ele era visto na escola como "aluno-problema" e que os demais docentes não acreditaram que ele chegaria ao fim da oficina, pois era tido como um aluno muito indisciplinado e não cumpria com as tarefas. Igor foi escolhido para atuar como personagem principal do filme. Ele sabia que não poderia faltar, pois sem ele não haveria oficina, mas esteve ausente em dois encontros. Não se lembrava de trazer o texto, nem parecia tê-lo ensaiado em casa para decorar as falas, mas atuava com concentração e quando podia ficava com algum equipamento, auxiliando o professor nas filmagens. 


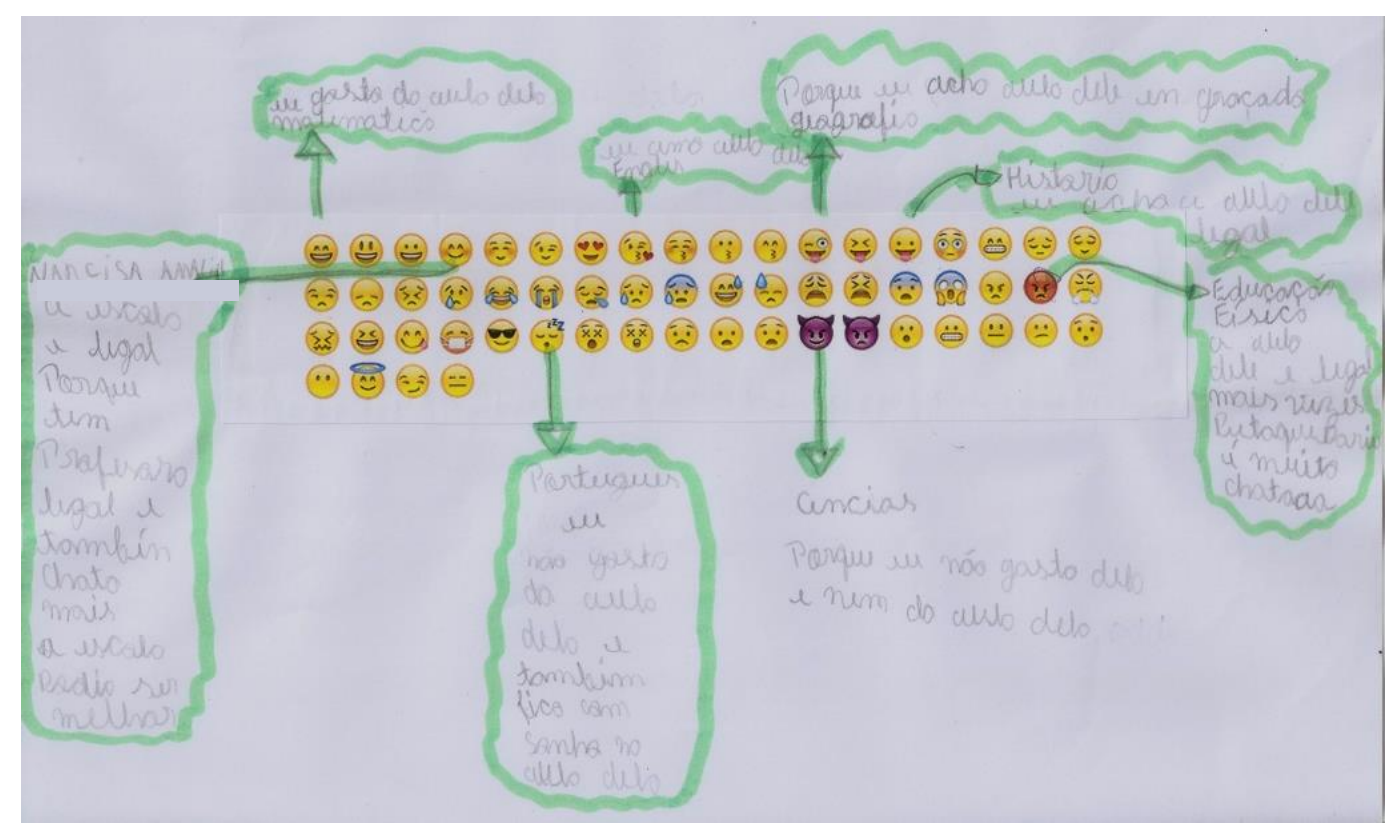

Figura 7 - Relação com as disciplinas e a escola - Igor Fonte: Arquivos da pesquisa.

Das sete disciplinas indicadas por Igor, cinco foram avaliadas com "eu gosto" ou "é legal": matemática, inglês, geografia, história e português - embora nesta última ele diga que sente sono na aula. Ele avalia a escola como legal e chata porque há professores legais, mas, de acordo com o aluno, ela pode melhorar.

Carla começou a oficina desinteressada das atividades de escolha da história para o filme, embora estivesse presente. No início, estava sempre com uma amiga que passava a aula inteira penteando os seus cabelos. Depois das férias, sua colega desistiu da oficina e Carla passou a se interessar mais pela finalização da escrita do roteiro. Depois, participou como personagem secundária do filme, mas começou a faltar muito e teve que ser substituída por Sueli. Carla exerce um papel de liderança na turma e ajudou com o som ou o microfone durante as gravações. 


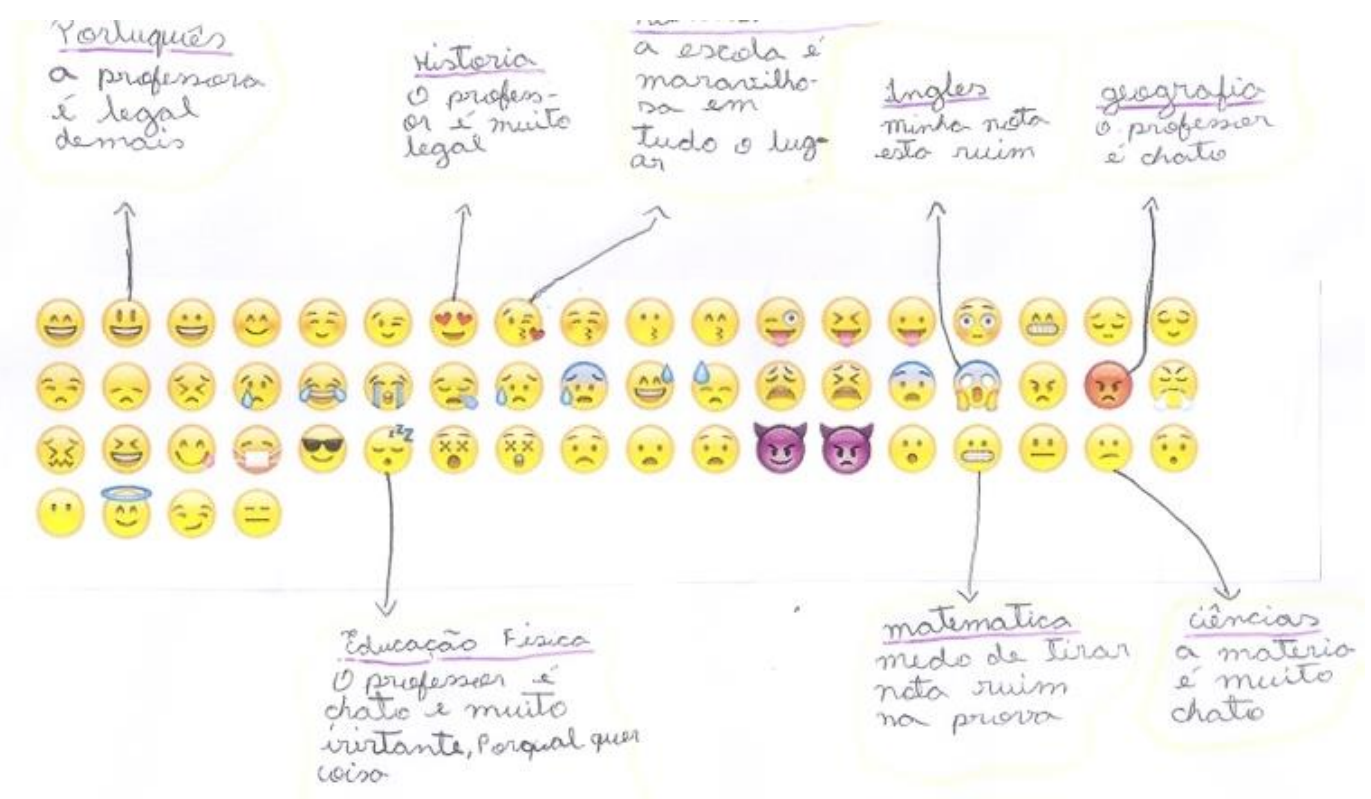

Figura 8 - Relação com as disciplinas e a escola - Carla Fonte: Arquivos da pesquisa.

A relação de Carla com as disciplinas também é descrita conforme sua relação com os professores ou com a própria matéria. A aluna relaciona 0 emoticon de susto à sua nota em inglês, demonstrando estar preocupada com isso. O mesmo ocorre com matemática, em que ela indica ter medo de tirar uma nota ruim na prova.

No início do ano, João fazia parte da outra turma de terça-feira, que acabou desistindo das aulas. Como ele quis continuar, passou para a turma que ainda continuava a frequentar. Ele estava sempre presente nas aulas, era pontual e, embora se mostrasse às vezes disperso, participava das atividades propostas. Dava poucas opiniões, quando solicitado, e geralmente estava assistindo ao que os demais decidiam. Nas filmagens, João fazia figuração ou se encarregava do microfone. Ele estava sempre presente, mesmo quando não participaria de nada nas cenas. Durante esse ano de observação da turma, o crescimento de alguns alunos, com relação à estatura e desenvolvimento corporal me chamou a atenção, como no caso de João. Depois das férias achei ele bem maior do que antes e sua voz estava começando a mudar, mas as atitudes moleques e as brincadeiras infantis eram as mesmas. 


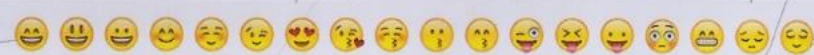

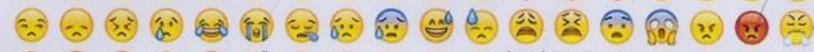

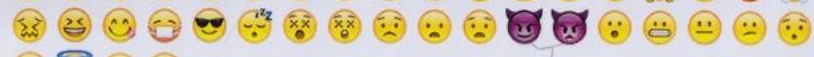

(.) 웅ㅇㅇ (-)

Figura 9 - Relação com as disciplinas e a escola - João

Fonte: Arquivos da pesquisa.

Chama atenção, nas respostas de João, como ele indica um emoticon de tristeza por não haver aulas de artes. Outros alunos avaliaram gostar dessa disciplina, o que indica que João não vai às aulas ou sua turma está sem professor de artes. Outros colegas da turma dele, como Sueli, disseram gostar da aula de artes. Pode ser que ela tenha avaliado a experiência com a disciplina, lembrando de outros momentos em que tinha essa aula. Como ele é um aluno brincalhão e agitado, eu esperava uma melhor avaliação das aulas de educação física, porém, ele escolhe dois emoticons de diabo (um sorrindo e outro zangado) para indicar que "é muito chato". Para ele, a escola é muito boa.

Sueli é uma garota com problemas auditivos, usa aparelho e isso não interfere em seu relacionamento com os colegas nem com o professor. Ela fala sempre muito baixo, dá suas opiniões quando necessário e responde às questões do professor. Ajuda as outras meninas da turma a ficarem atentas e está sempre informada sobre seus colegas e sobre os que acontece na escola. Ela possui celular e acessa a internet quando precisa saber de alguma coisa. Os colegas pedem seu celular emprestado e ela sempre está disponível para ajudar quem precisa. As filmagens estavam atrasadas e Sueli substituiu Carla, o que não foi um problema para ela, mas para o professor sim, pois ele reclamava que a aluna falava muito baixo. Depois de algumas cenas filmadas, eles conseguiram contornar esse problema. A cena final, que deveria ser feita na casa de algum aluno, aconteceu na casa de Sueli, que, junto com os pais, recebeu a todos nós durante uma manhã. 


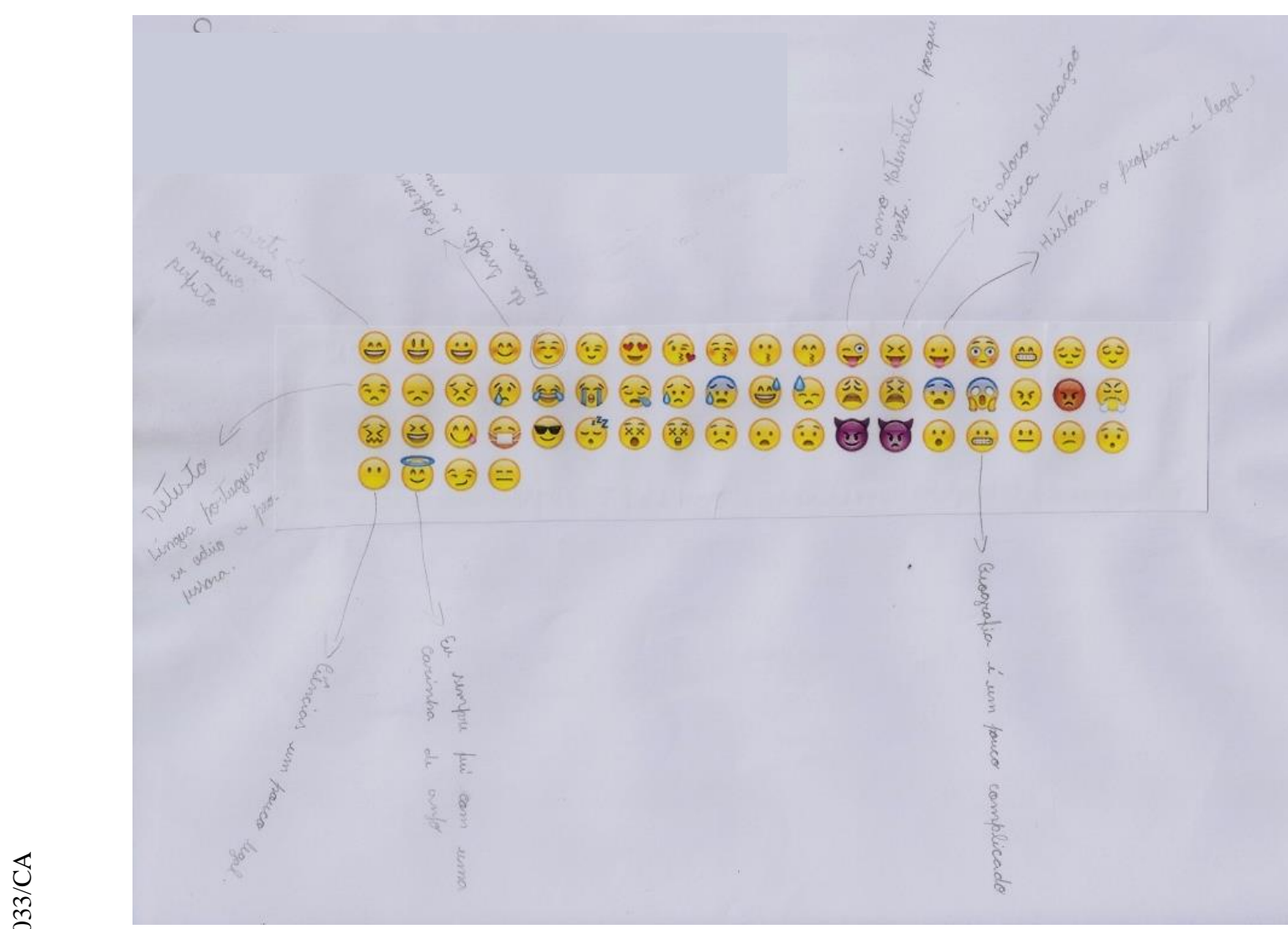

Figura 10 - Relação com as disciplinas e a escola - Sueli Fonte: Arquivos da pesquisa.

Sueli se identifica com matemática, educação física e artes e acha os professores de inglês e história legais. Por outro lado, detesta a professora de português e, para ela, geografia é uma matéria um pouco complicada. Ela não avalia sua relação com a escola, mas escolhe um emoticon de anjinho e diz que: "Eu sempre fui com uma carinha de anjo" - como não há indicação de disciplina alguma nesta frase, pode ser que esteja dizendo como ela vai à escola.

Vítor é um garoto muito calado. Poucas vezes deu sua opinião em sala de aula, mas participava das atividades e esteve presente na maior parte das aulas. Faltou a algumas aulas pouco antes do início das filmagens, mas depois retornou e entrou no ritmo, como se não tivesse estado ausente por alguns dias e tanto os colegas, o professor como ele, não mencionaram seu "sumiço". Logo que retornou, tomou conta do microfone e ficou nessa função a maior parte do tempo. Quando necessário, participou como figurante das cenas. 


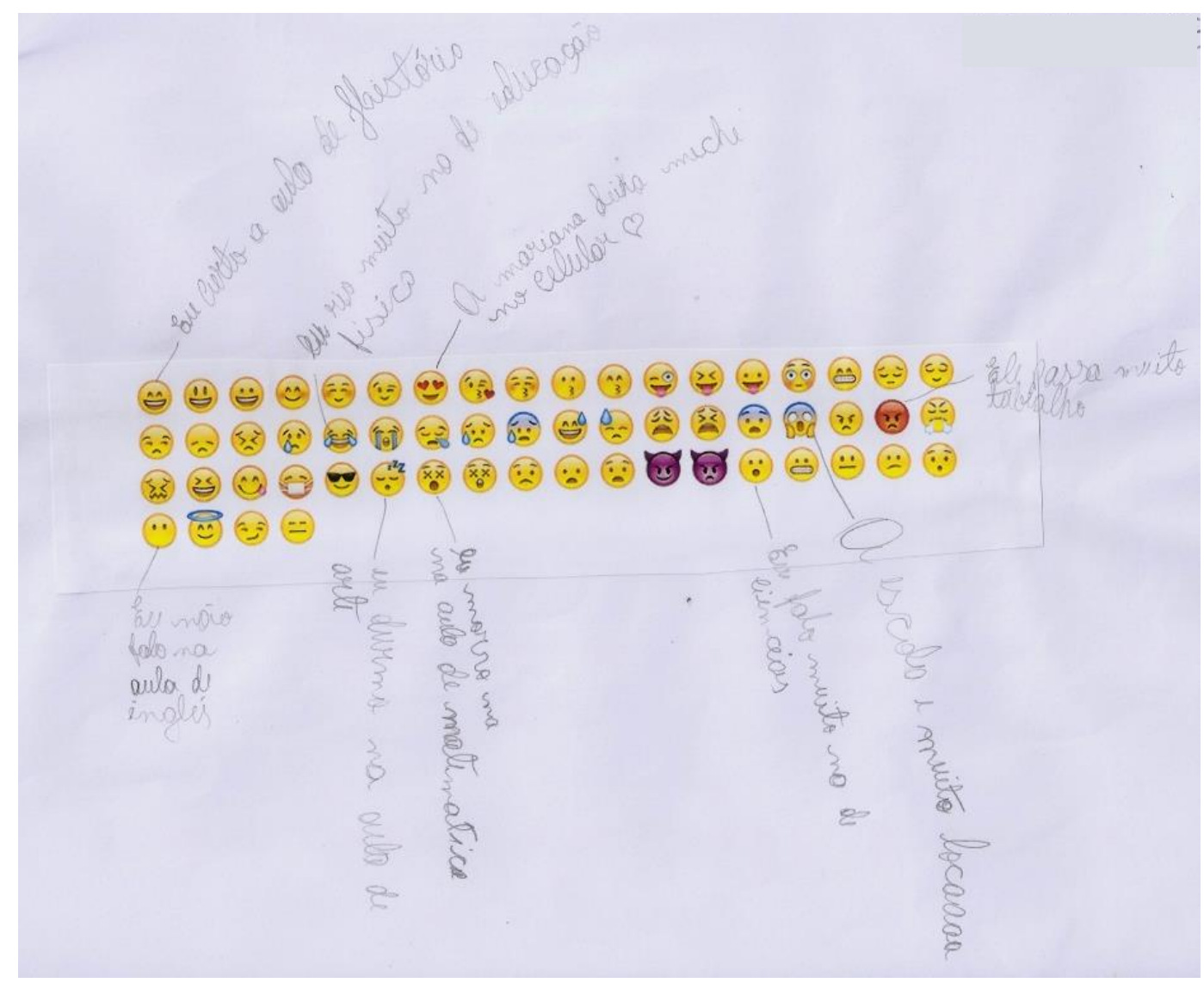

Figura 11 - Relação com as disciplinas e a escola - Vítor Fonte: Arquivos da pesquisa.

Embora seja bastante calado, Vítor indica na atividade que fala muito na aula de ciências (emoticon com boca aberta), mas não fala na de inglês (emoticon sem boca). Ele indica um emoticon com olhos em coração para uma professora que permite que ele use o celular nas aulas. Sua percepção é de que a escola é "muito locaaaaa", com emoticon de susto - o que não parece ser algo positivo.

Leo assumiu a função de líder do grupo. Quando ele começou a participar das aulas, o grupo iniciou a escrita do roteiro. Era ele quem conduzia as discussões sobre as atitudes dos personagens, o que eles diziam, como a cena seria feita e, assim, ajudou a deslanchar a escrita do roteiro que em quatro meses não havia se desenvolvido. Ele sabia ser o líder, tanto que se indicou como diretor do filme. Leo comentou comigo que fazia curso de vídeo fora da escola e observei que ele demonstrava algum domínio sobre a linguagem cinematográfica. Durante a aula que o professor deu sobre isso, apenas ele respondia às perguntas feitas para a turma. Leo veio de São Paulo e era um aluno novo na escola. Era um dos poucos que possuía celular e suas vestimentas e objetos indicavam que provinha de uma família com poder 
aquisitivo maior que a de seus colegas; várias vezes o vi saindo da escola de carro, com seu pai. Mesmo sabendo de sua posição de liderança na turma, faltava e chegava atrasado. No filme, embora fosse o diretor, poucas vezes indicava aos colegas o que deveriam fazer na cena. Por vezes, ficava responsável pela câmera, sendo sempre orientado pelo professor.

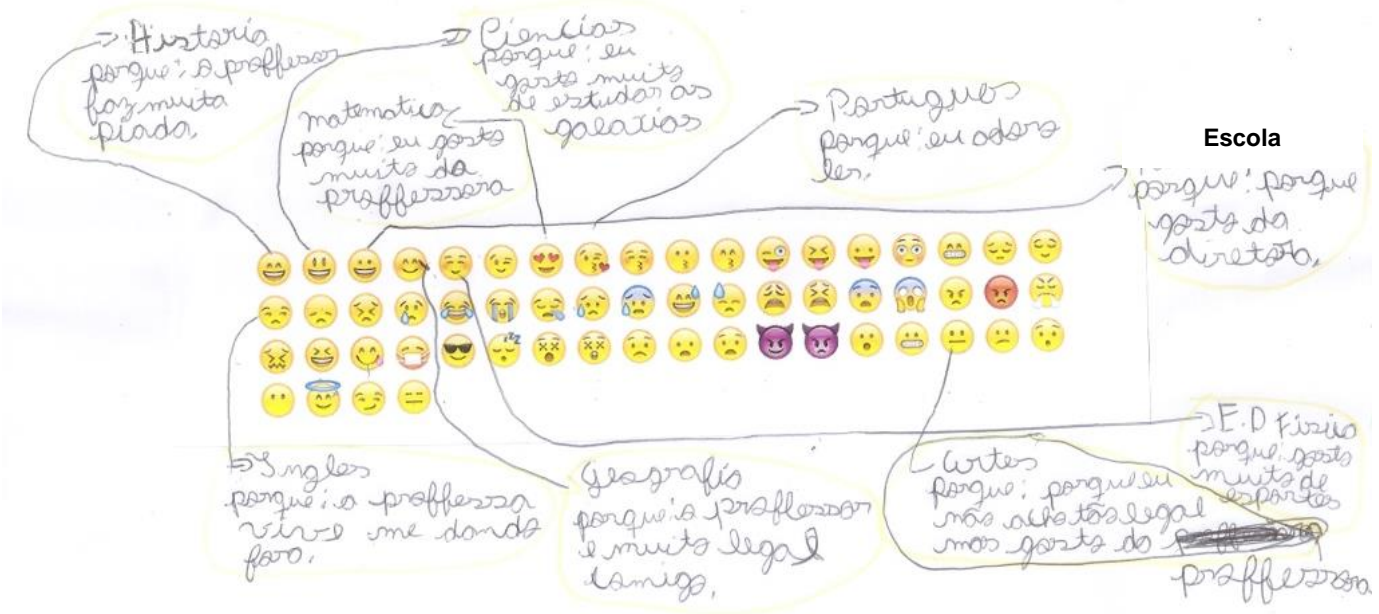

Figura 12 - Relação com as disciplinas e a escola - Leo

Fonte: Arquivos da pesquisa.

Leo indica sua relação com as disciplinas por gostar de ler (português), gostar de determinado assunto (galáxias - ciências). Ele indica que a professora de inglês "vive dando fora" nele e escolhe um emoticon decepcionado. Portanto, ele também relaciona seu gostar/não gostar das disciplinas pela relação estabelecida com os professores.

Vita fazia parte da turma desistente e, durante as filmagens, deixou de participar. Mesmo assim, estava sempre pela escola e de vez em quando fazia figuração nas cenas de sala de aula com vários alunos. No último dia, em que filmaram na casa de Sueli, ela estava lá. Posso dizer que Vita participou da oficina de longe, pois sempre que queria ou que dela precisavam, ela estava presente. 


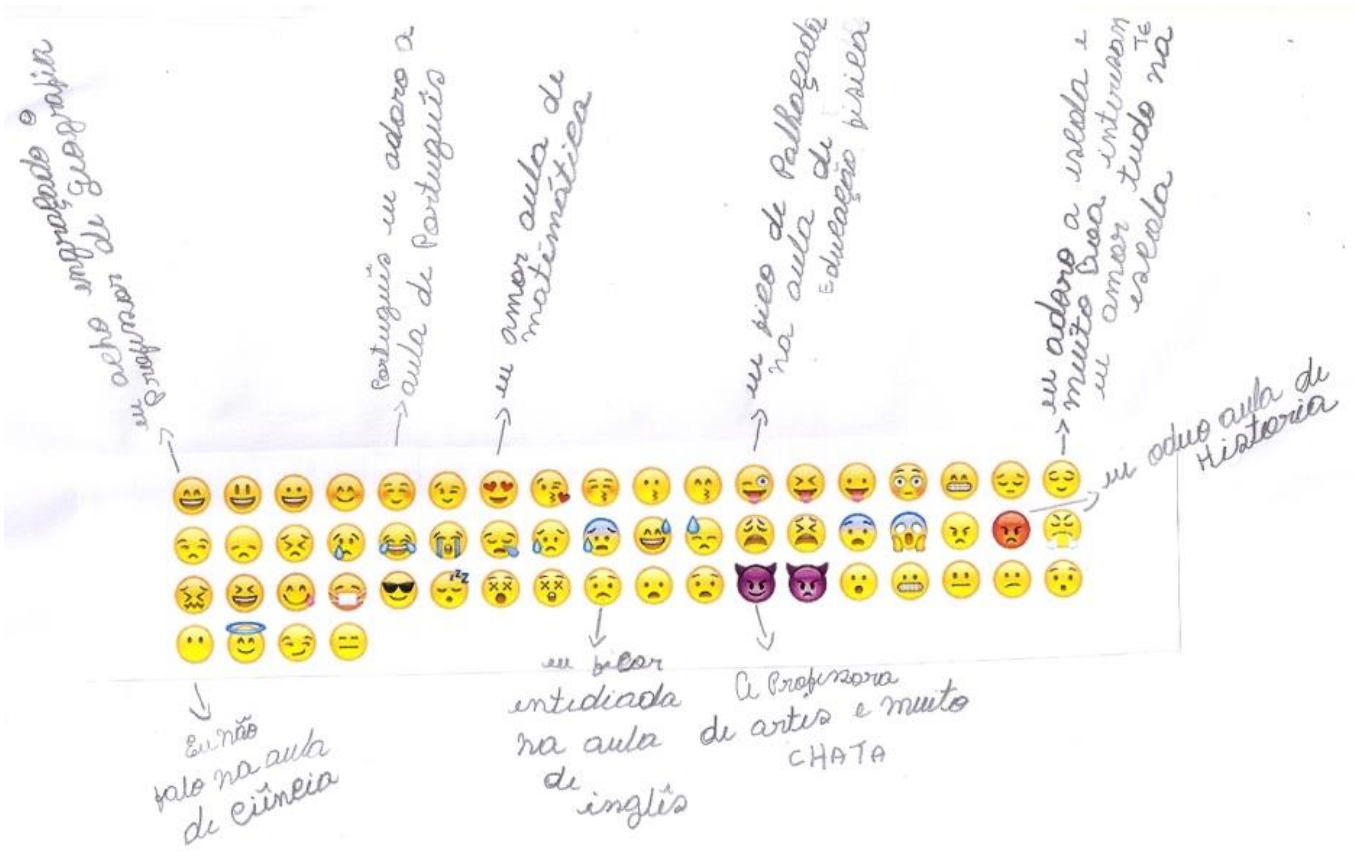

Figura 13 - Relação com as disciplinas e a escola - Vita Fonte: Arquivos da pesquisa.

Vita se mostrou tímida com os professores e comigo, mas com os colegas não. $\mathrm{Na}$ atividade, ela reconhece fazer palhaçadas na aula de educação física. Assim como Vítor, ela escolheu o emoticon sem boca, mas para indicar que não fala na aula de ciências. Os que simbolizavam algo como "adoro" e "amo" se repetem para português, matemática e para a escola.

Marcio foi outro aluno que participou "de longe". Em alguns momentos, faltava às aulas e depois retornava, ajudando no som e até fazendo a câmera. Não fez nenhuma cena como figurante ou ator. Seu "sumiço" pode ter ocorrido porque uma pessoa de sua família faleceu no meio do ano. 


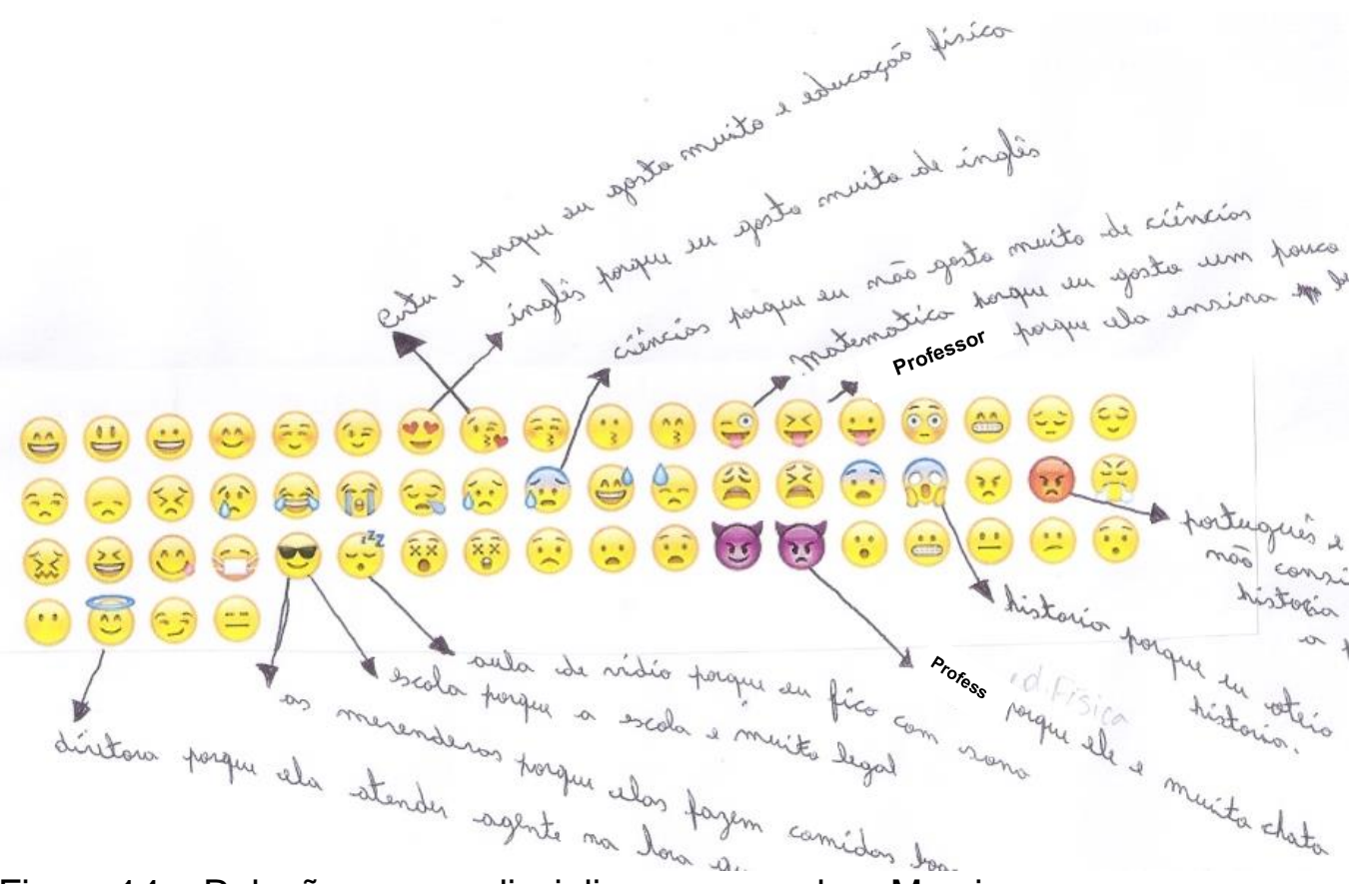

Figura 14 - Relação com as disciplinas e a escola - Marcio Fonte: Arquivos da pesquisa.

Marcio é um aluno muito calado e só falava quando solicitado. Apenas ele faz uma avaliação da aula de vídeo, e usa um emoticon com sono para isso. Usa o mesmo emoticon para avaliar a escola e as merendeiras, embora estas últimas não tivessem sido solicitadas por mim, na orientação da atividade. Ele também avalia a diretora separadamente da escola.

Essa apresentação mostra como a participação dos alunos era flutuante, como não havia papéis fixos para cada um deles nas atividades, a não ser dos dois personagens principais. Eles faltavam muito e chagavam a "sumir" da oficina. Às vezes eu os encontrava pela escola (no pátio, saindo do banheiro, entrando na sala de leitura) durante o horário em que estava ocorrendo a oficina, o que deixava claro que eles podiam ir até à escola naquele horário, mas preferiam estar fazendo outra coisa. Um fato que chamou atenção nessa observação foi que nunca o professor convidou uma menina para operar a câmera, e nem elas se ofereceram. Esse papel era sempre exercido ou pelo professor ou por algum garoto que se oferecia, pedia, ou que o professor chamava para fazer. 


\section{* Professor da oficina}

Quando ainda estava delineando o projeto de doutorado, busquei contatos de professores que trabalhassem com vídeos na escola e recebi de professores, coordenadores de projetos e de gestores da Secretaria Municipal de Educação do Rio de Janeiro a indicação para pesquisar a prática desse professor, pois todos conhecem seu projeto de oficinas nas escolas, onde ele trabalha e os filmes produzidos em suas oficinas sempre estão em eventos de cinema. Inclusive, esse professor já deu cursos na SME para formação de outros professores sobre cinema na escola, conforme ele me informou informalmente durante a pesquisa de campo. Além disso, ao pesquisar sobre vídeo nas escolas públicas da rede municipal, encontrei algumas matérias que falavam sobre o trabalho desse professor.

O primeiro contato que tive com ele ocorreu durante a pesquisa Mídia-Edu, quando acompanhei professores que desenvolviam, naquela ocasião, atividades com mídias nas escolas da rede municipal do Rio de Janeiro - conforme apresentei anteriormente. Aproveito os materiais que produzi naquela pesquisa e a entrevista que realizei com o professor naquele momento para apresentar sua a história com as aulas de vídeo e a proposta de sua oficina.

O professor é ator, licenciado em artes cênicas e entrou na rede municipal do Rio de Janeiro em 1999 para dar aulas de teatro. Em 2000, foi convidado para trabalhar em um programa de TV da Multirio e nos debates que ele fazia nas escolas municipais para os programas que gravava começou a:

[...] perceber que o vídeo tinha bastante poder de alcance, muito maior, talvez, do que o teatro. Eu fazia peça na escola e a gente apresentava pra poucos alunos, num espaço que não era apropriado. Então eu resolvi fazer uma experiência de tentar reproduzir na escola o programa que eu fazia na televisão. Assim eu peguei uma câmera emprestada e gravei um programa de debate com os alunos, [...] na escola [...]. A gente tinha um carrinho com uma TV que podia ir a todas as salas da escola, e aí eu vi que a coisa funcionava bem. E aí eu comecei a gostar da ideia e comecei a fazer isso mais vezes. (Entrevista concedida à pesquisadora, 2016).

O professor contou que passou dois anos fazendo essa experiência com vídeos, que ele considera bem simples, pois não fazia edição e tinha poucos equipamentos. Em 2003, aprimorou seu trabalho, pois conseguiu que um amigo que trabalhava em uma produtora de vídeo o ajudasse a editar o material. Assim, aprendeu a trabalhar com edição e com outros equipamentos relacionados à técnica, elaborando também roteiros com os alunos. Paralelo a 
isso, pesquisava como produzir materiais audiovisuais, trazendo sua prática na TV para sala de aula. Desde então, não parou mais com esse trabalho e investiu na produção de vídeos melhores, comprando um computador e uma câmera.

Nesse mesmo ano, fez outro concurso para a rede e assumiu uma segunda matrícula, parou de dar aulas de teatro e se dedicou às oficinas de vídeos em todas as escolas onde atua, criando filmes com os alunos e participando de festivais. Ele conta que já ganhou vários prêmios em festivais e que uma das escolas onde atuava montou uma ilha de edição e já ganhou outros equipamentos por conta dos filmes que os alunos produziram. Informou, ainda, que nesses quase 15 anos que trabalhou com produção de vídeos nas escolas municipais já produziu mais de 50 curtas-metragens com seus alunos.

Além disso, participou de congressos sobre mídia-educação, apresentando seu trabalho e numa dessas oportunidades foi indicado para levar seu filme para - Festival de Cinema do Rio. Assim, passou a pesquisar sobre essa possibilidade de enviar os filmes dos alunos para diversos festivais e, desde 2005, inscreve pelo menos um filme por ano em festivais; a média tem sido de 5 a 6 festivais nacionais por ano, como informou. O professor também já inscreveu filmes em festivais internacionais.

A oficina ministrada por ele integra a grade extracurricular da escola. No início do ano letivo, os alunos do $7^{\circ}$ ao $9^{\circ}$ anos, interessados em participar, inscrevem-se na seleção e, conforme a demanda e os tempos disponibilizados pelo professor, ele monta as turmas, dividindo-as por ano de estudo. As oficinas ocorrem no contraturno das aulas dos alunos, portanto, quem estuda pela manhã deve ter disponibilidade de estar na escola à tarde no dia e horário predeterminado pelo professor. Em 2017, as oficinas foram ofertadas às terçasfeiras pela manhã e às quartas-feiras à tarde. Além dessa escola, o professor dá esta mesma oficina em outra escola municipal da Zona Oeste e em uma renomada escola particular do Rio de Janeiro. Segundo informou, ministra a mesma oficina em todas essas escolas, sem distinção de metodologia. 


\section{6 \\ Oficinas}

As oficinas observadas tinham duração de uma hora e meia, mas muitas vezes eram intercaladas pelo recreio e os alunos saíam para lanchar - o que demandava pelo menos meia hora do tempo estabelecido de aula.

No período da tarde, as turmas que observei tinham atividades de $13 \mathrm{~h}-15 \mathrm{~h}$ e de 15h-17h; pela manhã, as oficinas ocorrriam de $8 \mathrm{~h}-10 \mathrm{~h}$ e de $10 \mathrm{~h}-12 \mathrm{~h}$. A turma observada a partir do segundo semestre, com qual fiquei até o término do trabalho de campo, acabou mudando seu horário de aula para aproveitar mais tempo e adiantar o que fosse possível. Assim, o professor solicitou que eles chegassem às $9 \mathrm{~h}$ e o término ficou combinado para $12 \mathrm{~h}$, com intervalo na hora do recreio.

Nos dias em que as oficinas ocorriam em sala de aula, gravei em áudio as aulas, usando, inicialmente, o gravador de longo alcance, e passando, após alguns dias, a usar o celular, pois percebi que os alunos ficaram pouco à vontade com o gravador e que o celular captava bem o áudio do contexto a ser analisado.

Nos diários, inseri as observações realizadas dentro e fora da sala de aula e registrei minhas impressões sobre o campo, as relações, os problemas, enfim, aquilo que me chamou a atenção sobre o ambiente e seus sujeitos, explicitando o que parecia ser relevante para a pesquisa. No segundo semestre, iniciada a gravação do filme pelos alunos, a dinâmica da oficina passou para fora da sala de aula (rua, pátio, entrada da escola, por exemplo) e não foi mais possível gravar os áudios como antes; nesses dias, os registros das atividades externas foram feitos apenas no diário de campo ou com auxílio do protocolo de observação.

\section{7}

\section{Atuação no campo}

A imprevisibilidade foi uma constante nesse campo de pesquisa, sendo difícil lidar com ela, pois a todo o tempo havia a impressão de que não seria possível fazer o número adequado de observações das oficinas ou de registro 
de protocolos. Em meio às decepções, deparei-me com a seguinte frase de Pierre Bourdieu, em um artigo de Perrelli et al. (2013, p. 275):

O homo academicus gosta do acabado. Como os pintores acadêmicos, ele faz desaparecer dos seus trabalhos os vestígios da pincelada, os toques e os retoques [...]. Muitas vezes estragam obras julgando dar-lhes os últimos retoques, exigidos pela moral do trabalho bem feito, bem acabado, de que a estética acadêmica era a expressão.

Quando me deparei com essa citação, encontrei uma análise daquilo que há tempos me atordoava em relação à produção de dados nesta pesquisa. Ao ler o texto onde encontrei esta epígrafe, encontrei um suporte teórico para minhas escolhas metodológicas e as situações de contato com o campo e seus sujeitos, pois as autoras afirmam, ainda com base no próprio Bourdieu, que a academia forma os pesquisadores para uma "ciência normal":

Assim formados, publicam os resultados de suas investigações somente após um trabalho de depuração que as expurga dos erros cometidos e as isenta de interrogações que possam colocar em xeque a sua respeitabilidade como cientistas e, ademais, a da própria ciência. Essa prática deixa de prestar uma grande contribuição à ciência, pois, ao se abster do exercício da vigilância epistemológica, o pesquisador deixa de produzir conhecimento reflexivo da própria atividade de pesquisar, e é justamente esta a condição necessária para que a ciência se coloque em discussão e caminhe no sentido da superação dos seus próprios obstáculos. (Perrelli et al., 2013, p. 276-277).

A partir dessa leitura, compreendi que descrever o percurso de pesquisa vai além de apresentar sujeitos, campo e situações observadas. Como pesquisadores, precisamos deixar claros também os problemas, escolhas e desafios, esclarecendo a maneira encontrada para vencer cada obstáculo e lograr... Não, essa escolha não combina com êxito sempre. Muitas pesquisas não são exitosas, mas antes de essas falhas serem publicadas, objetivos são modificados e as perguntas iniciais transformam-se em outras. Isso também aconteceu com a minha pesquisa. Ao perceber que não dispunha de elementos empíricos sólidos para atender aos objetivos iniciais, estes tiveram que ser modificados, levando em conta os dados produzidos no trabalho de campo. Weber (2009, p. 159-160) afirma que o diário de pesquisa, aquele em que o pesquisador anota suas divagações e dúvidas sobre seu campo e suas teorias:

[...] está destinado a permanecer em parte secreto: não nos livramos facilmente das especulações teóricas e conceituais, das hipóteses inúteis ou abandonadas, onde a ingenuidade ou os enganos registrados, se tornados públicos, teriam impacto na imagem do pesquisador, uma imagem que é construída pacientemente, ao longo dos textos publicados pelo etnógrafo-intelectual.

Assim, percebi que a academia tem regras que fazem com que a disseminação do conhecimento, realizada por meio da publicação das 
pesquisas, pareça algo que sempre logra êxito. No fim de tudo, a tese (ou o relatório final) geralmente apresenta a parte positiva do percurso percorrido, seus resultados e como a pesquisa vem contribuir para o campo do conhecimento em que se insere.

Essa reflexão não tem por fim condenar tais ações, mas indo na mesma direção que Perrelli et al. (2013), acredito que estarei contribuindo para minha própria formação e para a pesquisa em educação se trouxer para o texto também os insucessos e as experiências vividas no campo, assim como as novas questões que emergiram no período em que estive imersa naquele universo. 


\title{
4
}

\section{Olhar acadêmico sobre a produção audiovisual na escola}

\begin{abstract}
Para analisar as pesquisas acadêmicas que tratam de produção audiovisual na escola, realizei um levantamento nos bancos de teses da Biblioteca Digital Brasileira de Teses e Dissertações (BDTD) e da Coordenação de Aperfeiçoamento de Nível Superior (Capes). Também busquei artigos no portal de periódicos da Capes e nos anais das Reuniões Anuais da Anped. Para tanto, combinei descritores em português e inglês, considerados principais produção audiovisual, produção de filmes, produção de vídeos, produção de cinema - a alguns termos variáveis - educação, escola, sala de aula, alunos, estudantes. O recorte de tempo para busca focou entre as produções de 2010 até 2017 , a fim de obter um panorama mais recente do que foi produzido sobre esse tema pela academia.

Considerei para a análise, trabalhos que tratam de produções audiovisuais por crianças e jovens em espaços formais e não formais de educação. Assim, após a descrição dos conteúdos das teses, seguida de um quadro que sintetiza objetivos e resultados de pesquisas em nível de mestrado, apresento os resultados da pesquisa em periódicos indexados em bases de dados nacionais e internacionais, além de trabalhos divulgados na Anped que tratam do tema desta pesquisa.
\end{abstract}

\section{1 Teses e dissertações sobre produção audiovisual em contextos educacionais}

A busca por teses e dissertações no portal da Capes resultou em apenas uma tese que trata do tema, a qual apareceu também na busca realizada na BDTD, que apresentou 4 teses e 19 dissertações. Os estudos que tinham por tema a produção audiovisual, mas tratam de formação de professores e formação profissional dos alunos, não foram considerados neste levantamento. Neste capítulo, apresento três teses resultantes desta pesquisa, pois uma delas (Garbin, 2011) será abordada em momento posterior, quando apresento os artigos que tratam desse tema. As dissertações que foram consideradas como importantes para a discussão levantada aqui são apresentadas no final desta seção. 
Pimentel (2013) realizou uma pesquisa em uma escola de ensino médio, localizada na região administrativa do Cruzeiro, no Distrito Federal, que consistiu na realização da oficina "Cine Com Ciência", por meio da qual foram apresentados elementos de linguagem cinematográfica para os alunos, seguidos da montagem do vídeo "100\% Completamente Bem Resolvida". A produção teve por base a metodologia de videoprocesso, concebida pelo espanhol Joan Ferrés, e contou com a participação de nove alunos. Como resultados, o pesquisador destaca que:

[...] mesmo atualmente é preciso estudar a história da construção da linguagem cinematográfica para apreendê-la em sua extensão e complexidade, e que a estratégia de montar vídeos com os alunos abre possibilidades para o diálogo, gerando aprendizagem sobre a linguagem cinematográfica, além de permitir o debate de assuntos relativos ao universo juvenil, incluindo os estudados nas disciplinas das escolas. (Pimentel, 2013, p. 7).

$\mathrm{Na}$ conclusão de sua pesquisa, o autor considera a produção de vídeo na escola como um processo ainda embrionário, mas de grande potência para a escola, sendo o videoprocesso muito mais que entretenimento, pois:

Reforça a aprendizagem, na medida em que estimula o debate, promovendo a criticidade, a autonomia, a pesquisa, o senso de organização e a responsabilidade dos alunos. Nas palavras de Ferrés (1996, p. 22-23): "o videoprocesso equivale a falar de participação, de criatividade, de compromisso, de dinamismo. É uma modalidade na qual os alunos se sentem protagonistas." (Pimentel, 2013, p. 214).

Outro resultado encontrado em pesquisas sobre o uso do audiovisual na escola é o estímulo ao protagonismo dos jovens como importante viés de motivação na sua participação escolar, conforme mencionado na pesquisa de Pires (2014), que analisa produções audiovisuais feitas por jovens de uma escola pública de segundo segmento do ensino fundamental. A pesquisadora apresenta o curso no qual os jovens produziram seus vídeos, que tinha como objetivo:

[...] investigar o processo de produção audiovisual e as contribuições da linguagem e produção imagética para formação dos sujeitos, visando fundamentar a práxis pedagógica, a partir da autonomia dos educandos como Sujeitos que fazem escolhas e projetam coletivamente ações/produtos que ressignificam seus valores e identidade comunitária. (Pires, 2014, p. 8).

A pesquisa teve como campo uma escola pública e um curso de iniciação audiovisual, entendido como espaço educativo não formal na pesquisa. A autora afirma que a investigação permitiu "constatar alguns impactos na relação dos alunos com a produção imagética e com as representações deles como sujeitos" (p. 8). Ela destaca que o comportamento dos alunos da escola em que trabalhava como professora se modificava quando eles estavam participando de 
atividades com produção audiovisual, algo bem difundido pelas pesquisas que tratam desse tema:

Percebemos no decorrer de todos esses anos trabalhando com produção audiovisual que muitos desses meninos e meninas, que eram considerados indisciplinados, durante o trabalho de produção, quando estávamos nas locações escolhidas para as cenas, eles se mantinham concentrados e se apresentavam como crianças e jovens responsáveis, cientes de seus papéis e prontos a ajudar no que fosse necessário. Representava dessa forma uma incoerência com o comportamento que tinham dentro da escola, suas regras e tempos estanques. (Pires, 2014, p. 109).

Esse relato confirma o papel motivador e promotor de colaboração que pode ter o audiovisual na escola, seja na visualização e/ou na produção de filmes. A postura diferente que os jovens demonstram em relação às oficinas de produção de vídeos, por exemplo, pode ser justificada pelo tipo de linguagem usada nesse processo, uma vez que, como Pires (2014) afirma, as produções de vídeos desses alunos "falam a língua" deles, tornando o processo de ensinoaprendizagem mais significativo. Assim, a pesquisadora constatou que os impactos da relação dos alunos com a produção imagética estão no "espaço de fala", apresentando os jovens como sujeitos desse processo, vendo nos vídeos produzidos pelos alunos "um território que tem a função social histórica de desvelar os saberes que são tecidos nas suas comunidades, bem como, ressignificar os saberes que são apreendidos na escola." (Pires, 2014, p. 142).

A última tese encontrada nessa primeira busca, trata de uma pesquisa realizada com estudantes de ensino médio de uma escola particular de Campinas, que teve por objetivo "avaliar aspectos da percepção dos alunos acerca do próprio aprendizado a partir da descrição dos procedimentos realizados em sala de aula e dos seus resultados." (Miranda, 2015, p. 7). A pesquisadora compreende $\mathrm{o}$ aprimoramento de processos da linguagem audiovisual como relevante para a implantação de novas práticas de ensino que funcionem na desconstrução do que chama de "estratégias pedagógicas antigas".

Miranda optou pelo método fenomenológico e fez entrevistas com os estudantes para "discutir as experiências com produção de vídeo do ponto de vista dos sujeitos envolvidos no processo de ensino-aprendizagem e, assim, poder ampliar perspectivas de trabalho com ensino de audiovisual na escola a partir da reflexão crítica sobre a prática pedagógica." (Miranda, 2015, p. 7). A partir da experiência de quatro anos em que ministrou o curso de "Cinema e produção de vídeo" como disciplina regular do currículo de Artes para alunos do 
$1^{\circ}$ ano, a partir de 2009, ela faz uma vasta análise sobre o tipo de espectador formado atualmente para a internet, que também passou a ser produtor de imagens e compartilha suas produções na rede sem, como ela afirma, ter uma formação para tanto. Miranda (2015) realizou entrevistas com os alunos e concluiu que:

[...] os estudantes passaram a atentar para detalhes antes ignorados (por serem desconhecidos) e que a percepção dos muitos sentidos das imagens e dos sons em conjunção ficou mais aguçada depois das propostas de trabalho realizadas durante o curso. Muitas das transformações mencionadas pelos alunos (e presentes nos produtos produzidos por eles) puderam ser vivenciadas, também, pela professora e, pode-se dizer que a experiência do projeto teve efeito intenso sobre ambos os envolvidos no processo de ensino-aprendizagem. (p. 65-66).

Sabendo que os portais da Capes ou da BDTD nem sempre estão atualizados com as últimas pesquisas defendidas, realizei uma busca em sites de programas de pós-graduação por teses que tratassem do assunto. Além disso, em contato com outros pesquisadores, tomei conhecimento de pesquisas atuais sobre o tema e de estudos internacionais, chegando a outros trabalhos importantes para a discussão aqui levantada.

Husbye (2013) estrutura sua tese sobre os conceitos de múltiplas modalidades e tecnologias ligadas à literacia na educação; ele promove cursos de produção de filmes, no período de férias, para alunos de ensino fundamental. O trabalho busca, entre outras coisas, compreender como os participantes se utilizam dos espaços escolares durante essas atividades e de que maneira crianças e adolescentes se colocam como produtores criativos nessa experiência. A proposta é uma pesquisa-ação, em que o próprio pesquisador promove atividades de produção e registra os acontecimentos para posterior análise.

Essa pesquisa é relevante para esta tese, pois apresenta metodologias e aprendizagens envolvidas na feitura de um filme por estudantes. Além disso, será tomada como fonte de interlocução na análise dos dados que produzi em minha investigação.

Labrunie (2017) desenvolve um estudo exploratório sobre a produção de vídeos na escola. A autora analisa vídeos de alunos do ensino fundamental e médio do Colégio Pedro II, a fim de compreender "as concepções e processos envolvidos na prática de criação de vídeos na escola." (p. 59). Para tanto, entrevistou professores e alunos dessa escola e suas análises apontam para as crenças que os professores têm em relação aos alunos como "prontos" para filmar, uma vez que têm acesso a diversos conteúdos audiovisuais, além de 
perceberem a produção de vídeos na escola como uma atividade relevante para aprendizagem de conteúdos e desenvolvimento de outras habilidades:

Os docentes destacam a organização e planejamento necessários à confecção do vídeo, a divisão de tarefas do trabalho em grupo, a criatividade, a superação da timidez, a diversão, a autoexpressão. [...] Um dos alunos também menciona a questão do planejamento, olhando da perspectiva de quem tem que produzir o vídeo, e reconhece que é necessária uma organização rigorosa, em concordância com a professora [...]. (p. 150).

Alguns dos alunos entrevistados se revelaram insatisfeitos com a produção dos vídeos quando solicitados como atividades de avaliação, preferindo, nesse caso, os testes. Os professores avaliam essa experiência como positiva, entendendo que eles mesmos aprendem com isso:

Os docentes, por sua vez, também avaliam os vídeos positivamente. Em particular, apreciam a criatividade dos alunos: em suas falas, usaram vocábulos e expressões como "desenvoltura dos alunos", "autonomia", "criatividade", "fiquei apaixonado", "capacidade dos alunos", etc. para designar suas impressões. As opiniões negativas foram no sentido de que alguns vídeos eram "ruins" em conteúdo, "arrastados" e com técnica ruim. [...] Alguns acreditam que eles próprios também aprenderam bastante com a atividade, Nina, por exemplo, disse que "aprendeu mais do que eles". (Labrunie, 2017, p. 162).

Assim, a tese de Labrunie é relevante no sentido de apresentar uma experiência de produção de vídeos na escola bastante atual e traz elementos importantes para a discussão sobre as impressões que alunos e professores possuem a respeito desse tipo de atividade.

Outra pesquisa relevante para esta tese foi desenvolvida por Pacheco (2015) e analisa projetos de cinema e educação desenvolvidos em Portugal e no Brasil, a fim de conhecer suas metodologias e pedagogias. Fundamentada nos pressupostos da mídia-educação, a investigação procura:

[...] conhecer diferentes projetos de cinema e educação, suas metodologias, pedagogias, com que frequência eles são implementados, as políticas públicas existentes na área e tentar perceber o que adultos - normalmente no papel de coordenadores e educadores - e jovens - normalmente no papel de educandos pensam sobre os projetos em que participam, o que é desenvolvido e o que de facto resulta da sua implementação. (p. 145).

A autora baseia-se no cinema enquanto uma das fontes da educação audiovisual que pode contribuir para a literacia midiática. Essa pesquisa abre caminhos para a presente tese, uma vez que aborda metodologias do cinema/audiovisual em contextos educativos, problematizando sua contribuição para a escola e analisando a própria constituição desse campo. Pacheco indica, entre outros achados, como na prática a maioria dos projetos não consegue atender aos objetivos delineados em suas propostas: 
Estes projetos, que em suas raízes teóricas possuem grandes e interessantes objetivos, na prática, na maioria das vezes, o máximo que conseguem atingir é permitir aos educandos saberem que existe esta forma de arte, ou de se fazer cinema, que é bastante diferente da que eles estão habituados a assistir, seja na televisão, seja através do DVD, nos sites da internet ou no próprio cinema. (Pacheco, 2015, p. 116).

Essa avaliação dos projetos que a autora realiza foi relevante para minha análise da metodologia utilizada pelo professor observado no trabalho de campo. Além disso, os relatos dos jovens sobre os projetos que ela observou foram tomados como fonte para analisar a percepção dos alunos que participaram desta pesquisa acerca da experiência na oficina de vídeo.

Tanto a pesquisa de Pacheco (2015) como a de Labrunie (2017) foram realizadas por pesquisadoras que não promoveram a prática observada na investigação. Embora isso não desmereça em nada as demais pesquisas, é importante destacar que a maior parte dos estudos encontrados neste levantamento trazem relatos de atividades desenvolvidas pelo próprio pesquisador, de duas formas: ele é professor e realiza atividades de produção de vídeos com seus alunos ou é um pesquisador que propõe oficinas de produção fílmica para crianças e jovens para desenvolver sua pesquisa. Algumas poucas pesquisas iniciam com a proposta de observar e analisar oficinas, mas os pesquisadores acabam oferecendo alguma consultoria ou dão aulas no campo de pesquisa, como ocorreu com Berti (2016).

A tese de Berti (2016) apresenta a produção de filmes por jovens por meio de criação de Minutos Lumière ${ }^{19}$ em dois projetos observados, um brasileiro (Cinead) e outro espanhol (Cinema en Curs), que realizam cinema dentro e fora da escola. De acordo com a autora:

A pertinência dessa metodologia se deve ao fato de, ao filmar um plano fixo, com duração de um minuto, temos a oportunidade de rememorarmos a infância do cinema, conectando-nos com o primeiro ato cinematográfico; revelando as condições temporais, espaciais e técnicos enfrentados pelos irmãos franceses àquela época, pois "rodar um plano é colocar-se no coração do ato cinematográfico, descobrir que toda potência do cinema está no ato bruto de captar um minuto do mundo" (BERGALA, 2008, p. 210). Essa experiência de fazer cinema é autoral, dado que só um estudante é responsável por eleger, dispor e capturar os elementos presentes no mundo e assumir, diante de todos, a sua escolha política e estética. (p. 85).

${ }^{19}$ Exercício criado por Alain Bergala e Nathalie Bourgeois, inspirados por sua vez nos irmãos Lumière. A proposta consiste em filmar uma cena de até um minuto com câmera fixa. De acordo com Berti (2016, p. 85): "A pertinência dessa metodologia se deve ao fato de, ao filmar um plano fixo, com duração de um minuto, temos a oportunidade de rememorarmos a infância do cinema, conectando-nos com o primeiro ato cinematográfico; revelando as condições temporais, espaciais e técnicas enfrentadas pelos irmãos franceses àquela época. [...] A produção do Minuto Lumière assume um caráter 'original' e, ao mesmo tempo introdutório do cinema, ao passo que os estudantes podem rememorar a experiência primeira do ato de filmar, ao colocarem-se diante de uma câmera fixa e filmar um plano de um minuto pela 'primeira vez'." 
Em sua pesquisa, a autora busca compreender: "quais gestos pedagógicos a experiência com o Minuto Lumière revela? Que relação educativa, que forma de estar no mundo, essa experiência promove?" (Berti, 2016, p. 9), a partir da observação das oficinas e análise das produções realizadas pelos estudantes. Como resultado da análise, a pesquisadora aponta que a presença do cinema na escola, com a produção dos Minutos Lumière, estimula os alunos ao "gesto pedagógico de prestar atenção ao mundo". Em filmes que revelam o olhar para atividades corriqueiras de seu cotidiano, os jovens que produzem os Minutos Lumière experimentam diversos gestos pedagógicos, que vão desde pesquisar, avaliar e selecionar - "No Minuto Lumière os alunos precisam prever um complexo de especificidades para eleger o plano, a fixação da câmera, a disposição dos elementos cinematográficos e a melhor hora de atacar." (p. 77) até oferecer alguma materialidade do mundo, prestar atenção ao mundo e amor ao mundo:

[...] quando convertidos em exercícios escolares, os Minutos liberam o mundo, ou pelo menos a maneira funcionalista predominante de entendê-lo (como lugar de aplicabilidade, com um dado a priori). O exercício com o Minuto solicita gestos ininterruptos de estudo quando, por exemplo, alguma coisa do mundo convoca a atenção do estudante, solicitando um olhar para fora de si mesmo - o que desestabiliza inicialmente, pois o que está fora de alcance, apresenta-se como desconhecido. Mas, por isso mesmo, pode ser tão fascinante. (p. 169).

Outras teses que têm por base a realização de Minutos Lumière para a produção de filmes são as de Domingues (2016) e Olmeczuck (2016). A primeira tem como foco a exploração de sons a partir de exercícios com análise de filmes. A pesquisa teve por sujeitos alunos do Instituto Nacional de Surdos (Ines), do Instituto Benjamin Constant (IBC) e do CIEP José Lins do Rêgo - São João de Meriti, e, entre as atividades observadas, analisou a produção de vídeo dos jovens que participaram da pesquisa e as relações criadas por eles entre sons e imagens nessa experiência. Olmeczuck (2016), por sua vez, apresenta dois projetos de cinema para crianças em hospitais. A autora promoveu oficinas para crianças internadas em um hospital de tratamento oncológico em Cuba e em um hospital universitário no Brasil, que tinham como proposta metodológica: produção de Minutos Lumière; descobrir onde está a câmera; produzir 5 fotos diferentes de um mesmo objeto; produzir uma história a partir de 5 fotos; exibição do curta feito pelas crianças no hospital; entre outros.

Os nove trabalhos aqui descritos, cujo foco de pesquisa recai sobre a produção audiovisual em contextos educativos, ajudam a compreender o lugar e a importância dessa discussão na atualidade, sobretudo no que diz respeito a 
metodologias utilizadas nas pesquisas e aos percursos teóricos que embasam os estudos nesse campo.

Para ampliar o olhar sobre pesquisas específicas que tratam de produção audiovisual na escola, apresento um quadro com as dissertações selecionadas no levantamento realizado na página da Capes e na BDTD e em sites de programas de pós-graduação em educação, além de outras citadas em revisões de literatura das teses aqui apresentadas.

Ao todo, foram encontradas 23 dissertações, defendidas a partir do ano 2010, com pesquisas desenvolvidas com crianças e jovens, alunos da educação básica, em atividades formais e não formais de educação e que tratam especificamente de produção audiovisual na escola. 


\begin{tabular}{|c|c|c|}
\hline Ano & Autor & Título \\
\hline 2010 & Garcia & $\begin{array}{l}\text { Reflexões sobre currículo e linguagem a partir de uma } \\
\text { experiência da Escola de Cinema no CAp/UFRJ }\end{array}$ \\
\hline \multirow{4}{*}{2011} & Faria & $\begin{array}{l}\text { A linguagem cinematográfica na escola: o processo de } \\
\text { produção de filmes na sala de aula como prática pedagógica }\end{array}$ \\
\hline & Costa Oliveira & $\begin{array}{l}\text { Audiovideografia e cultura audiovisual: um estudo de caso com } \\
\text { alunos do 9o ano do ensino básico em Educação Visual, no } \\
\text { âmbito do projecto curricular de turma }\end{array}$ \\
\hline & Oliveira & $\begin{array}{l}\text { Fazendo vídeo na escola, o audiovisual como instrumento de } \\
\text { mediação pedagógica }\end{array}$ \\
\hline & Pedrosa & $\begin{array}{l}\text { Nas mãos dos jovens: modalidades de uso do celular para } \\
\text { produção de vídeos no contexto de uma escola pública }\end{array}$ \\
\hline \multirow{3}{*}{2012} & Marinovic & $\begin{array}{l}\text { Produção de vídeos caseiros pelos próprios alunos como } \\
\text { estratégia para melhorar a aprendizagem dos conceitos } \\
\text { abordados nas aulas regulares de física do ensino médio... }\end{array}$ \\
\hline & Paz & $\begin{array}{l}\text { Saracuruna News: produção audiovisual como dispositivo de } \\
\text { subjetivação entre jovens da periferia de Duque de Caxias }\end{array}$ \\
\hline & Silva & Arte, mídia e cinema na escola \\
\hline \multirow[t]{2}{*}{2013} & Prandini & $\begin{array}{l}\text { A cor na voz: linguagem e identidade negra em histórias de } \\
\text { vida digitalizadas contadas por meio de práticas } \\
\text { educomunicativas }\end{array}$ \\
\hline & Lima & $\begin{array}{l}\text { Atenção gravando! Produção de vídeos por alunos do ensino } \\
\text { médio - a língua como objeto de reflexão }\end{array}$ \\
\hline \multirow{4}{*}{2014} & Costa & $\begin{array}{l}\text { Pedagogia da imagem: a autoria na relação } \\
\text { educador/educando durante o processo de produção de vídeos } \\
\text { na escola }\end{array}$ \\
\hline & Luna & $\begin{array}{l}\text { Luz, câmera, ação: os vídeos na educação em ciências e } \\
\text { produção de saberes }\end{array}$ \\
\hline & Nogueira & $\begin{array}{l}\text { Letramento(s) digital(is) e jovens de periferia: o transitar por } \\
\text { (multi)letramento(s) digital(is) durante o processo de produção } \\
\text { de vídeos de bolso }\end{array}$ \\
\hline & Norton & O cinema e o rural em uma escola no campo \\
\hline \multirow{6}{*}{2015} & Celestino & Crianças e suas narrativas audiovisuais \\
\hline & Sato & $\begin{array}{l}\text { Tecnologias digitais da informação e comunicação: } \\
\text { explorando as possibilidades pedagógicas da produção de } \\
\text { vídeos }\end{array}$ \\
\hline & Silva & $\begin{array}{l}\text { Luz, câmera, assimetria na inter-ação: funções do professor } \\
\text { assumidas por alunos }\end{array}$ \\
\hline & Dall'Agnol & $\begin{array}{l}\text { Produção audiovisual como recurso didático-pedagógico no } \\
\text { ensino de história: "como me veem?", "como eu vejo?" }\end{array}$ \\
\hline & Lima & $\begin{array}{l}\text { Literacinese ou da escrita [literária] com imagens... Em } \\
\text { movimento }\end{array}$ \\
\hline & Oliveira & $\begin{array}{l}\text { Uma metodologia para a produção de audiovisual: o uso de } \\
\text { tecnologias } \\
\text { emergentes com os jovens }\end{array}$ \\
\hline 2016 & Saldanha & $\begin{array}{l}\text { Oficina educomunicativa de produção de vídeos: construção de } \\
\text { significados sobre problemas socioambientais }\end{array}$ \\
\hline 2017 & Silva & Uma experiência de cinema expandido no espaço escolar \\
\hline 2018 & D'Andrea & $\begin{array}{l}\text { Contato: um abecedário audiovisual por estudantes de uma } \\
\text { escola de cinema }\end{array}$ \\
\hline
\end{tabular}

Quadro 2 - Dissertações sobre produção audiovisual realizada por crianças e jovens da educação básica ${ }^{20}$

Fonte: Elaboração própria.

${ }^{20}$ No Apêndice $\mathrm{D}$ desta tese, apresento um quadro com objetivos e resultados dessas pesquisas, entre outras informações. 
Ao analisar os resultados dos pesquisadores sobre a contribuição da produção de vídeos em contextos educativos, fica claro que as percepções sobre esse tipo de atividade são bastante variadas, conforme apresento na figura a seguir:

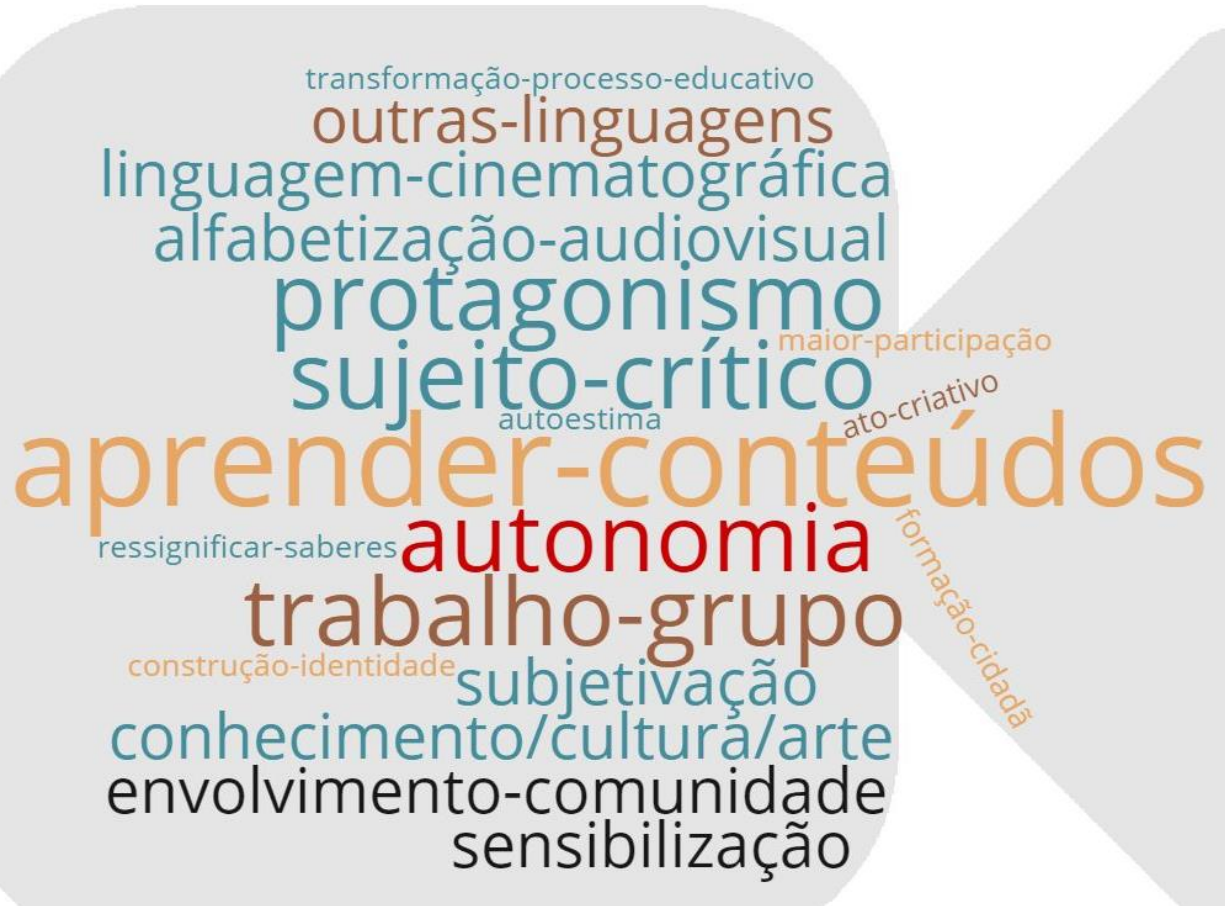

Figura 15 - Nuvem de palavras sobre percepção da produção audiovisual nas dissertações

Fonte: Elaboração própria.

Essa imagem revela como "aprender conteúdos" ainda é o maior objetivo dos projetos de produção de vídeos na escola, enquanto "ato criativo", ou seja, uma forma de experiência artística, ainda é algo menos citado nas pesquisas. Isso mostra que o cinema na escola continua sendo mais usado como instrumento por meio do qual se aprende algo do que como uma arte em si, conforme compreendem alguns teóricos de cinema e educação (Bergala, 2008; Fresquet, 2013). Os pesquisadores percebem a forte influência desse tipo de atividade para promover o protagonismo dos participantes e entendem que processos como esse são capazes de formar sujeitos críticos, autônomos e protagonistas de sua própria aprendizagem. Ao promover o contato com a linguagem cinematográfica, a escola oportuniza a alfabetização audiovisual de crianças e jovens, colocando-o em contato com outras linguagens além da escrita. As pesquisas consideram, ainda, que projetos de produção de vídeo permitem que os jovens se envolvam com sua comunidade (onde moram ou 
escolar). Entre os resultados das pesquisas aqui descritas, aparecem menos, porém é relevante destacar, uma vez que são achados recorrentes em pesquisas sobre o tema: formação cidadã, maior participação dos estudantes, construção de identidades e melhoria da autoestima, ressignificação de saberes e transformação do processo educativo. A abordagem que tem a produção de vídeos na escola está intimamente ligada aos pressupostos teóricos que os professores/pesquisadores seguem e as crenças que carregam sobre a potência ou a subserviência do audiovisual no processo de ensino-aprendizagem.

Em sua pesquisa de doutorado, Labrunie (2017) faz um estudo exploratório sobre as pesquisas que tratam da produção de vídeos na escola e apresenta em sua análise alguns dos trabalhos arrolados na presente pesquisa. A autora organiza as pesquisas encontradas em dois grupos: aquelas que tratam da produção de vídeo em disciplinas específicas (conduzidas em sala de aula ou como dever de casa) e aquelas cuja produção de vídeo ocorre em oficinas fora de sala de aula (no contraturno, com grupos específicos, idades diferentes). Especificando ainda mais sua análise, Labrunie (2017) destaca, nesses dois grupos, as propostas de produção que levam em conta: conteúdos curriculares ou extracurriculares. Por fim, dentro de cada uma dessas duas últimas categorias, a pesquisadora apresenta as teses e dissertações cujo foco recai nos seguintes aspectos: análise do vídeo, análise do processo, ponto de vista do docente, e ponto de vista do aluno. Com um recorte temporal a partir de 2004, muitos dos trabalhos analisados por essa autora foram também arrolados por mim neste capítulo.

O recorte que apresento a seguir se refere ao foco teórico-metodológico das teses e dissertações indicadas em meu levantamento. Aqui, retomo a discussão iniciada na introdução deste trabalho, quando apresentei o que chamei de duas vertentes que tratam do cinema/audiovisual na escola, nomeadas por mim de: mídia-educação e cinema-educação.

As teses de Berti (2016), Domingues (2016) e Olmeczuck (2016), entre outras pesquisas (Garcia, 2010; Norton, 2014; Silva, 2017), seguem o mesmo pressuposto base teórico-metodológico. Como indica Olmeczuck (2016, p. 36), tais projetos são orientados pela proposta formulada no âmbito do grupo de pesquisa Cinead:

[...] uma abordagem do cinema pelo avesso, num exercício mágico e curioso de desvendar a fantasia, a imaginação e o sonho da criação cinematográfica. $O$ grupo de pesquisa como um todo aposta na hipótese de que existe uma pedagogia da própria imagem, expressa no modo como o cinema, pelas escolhas 
dos cineastas, nos faz ver o mundo por um determinado enquadramento, na disposição da cena com tais objetos, com aquelas e não outras cores e nuances, em um ritmo e intensidade, acrescido de tais texturas, silêncios ou sons. Trata-se, portanto, de pensar o cinema desde a sua dimensão criadora compartilhando modos de ver o mundo, sofrer o mundo e criar o real.

Essa vertente teórica que pensa o cinema na escola, nomeada aqui de cinema-educação, está embasada, como já indiquei, na perspectiva defendida por Alain Bergala (2008) que, de acordo com Olmeczuck (2016, p. 36):

[...] distingue o ensino de arte e a educação artística, defende o cinema como arte em contraponto ao cinema como mídia ou comunicação, opta por uma leitura criativa do cinema ao invés da perspectiva da linguagem, sugere exercícios de criação cinematográfica que enfocam o desenvolvimento de uma sensibilidade estética, apresenta a curadoria de alguns filmes que compuseram um acervo especial de obras disponibilizadas nas escolas e provoca em meio a tudo isso, a função social da pedagogia, da escola, do professor.

As pesquisas produzidas por integrantes do Cinead e por outros grupos de pesquisa que se ancoram nas ideias de Bergala (2008) levaram-me a levantar um questionamento sobre o campo em que se insere minha pesquisa: quais abordagens teóricas embasam atualmente a produção audiovisual na escola? Há diferenças conceituais e metodológicas a serem consideradas nas pedagogias utilizadas nessas propostas? Em que medida os professores tomam como referência metodologias previamente determinadas e reinventam a produção audiovisual com seus alunos, criando uma pedagogia própria? O processo de produção audiovisual na escola pode ser considerado um gesto de criação, conforme indicam Fresquet $(2011,2013)$ e Migliorin $(2010,2014)$, ou é uma atividade voltada para a literacia midiática, como entendem pesquisadores da mídia-educação (Fantin, 2014; Pacheco, 2015; Pereira, 2000)? Essas questões foram desenvolvidas no próximo capítulo.

\section{2}

\section{Artigos sobre produção audiovisual na escola}

Para ampliar a revisão de literatura, pesquisei também por artigos em periódicos indexados na SciELO e em outras bases de dados nacionais e internacionais. A busca contou com a mesma combinação entre termos principais e variáveis que utilizei com as teses e dissertações e o mesmo recorte de período: 2010-2017. Entre os 16 resultados, selecionei apenas aqueles relacionados à produção audiovisual em contexto escolar: 


\begin{tabular}{|c|c|c|}
\hline Autores & Título & Periódico \\
\hline $\begin{array}{l}\text { Marcus Vinicius } \\
\text { Pereira; Susana de } \\
\text { Souza Barros }\end{array}$ & $\begin{array}{l}\text { Análise da produção de vídeos por } \\
\text { estudantes como uma estratégia } \\
\text { alternativa de laboratório de física no } \\
\text { ensino médio }\end{array}$ & $\begin{array}{l}\text { Rev. Bras. Ensino } \\
\text { Fís. v. 32, n. 4, São } \\
\text { Paulo, out./dez. } 2010\end{array}$ \\
\hline Michel Clarembeaux & Film education: memory and heritage & $\begin{array}{l}\text { Comunicar, v. 18, n. } \\
35, \text { p. 25-27, jan. } \\
2010\end{array}$ \\
\hline Amparo Porta & $\begin{array}{l}\text { The musical offers of children's } \\
\text { programming on as its hearing } \\
\text { universe }\end{array}$ & $\begin{array}{l}\text { Comunicar, v. 19, n. } \\
\text { 37, p.177-179, mar. } \\
2011\end{array}$ \\
\hline Monica Cristina Garbin & $\begin{array}{l}\text { Uma análise da } \\
\text { produção audiovisual colaborativa: } \\
\text { uma experiência inovadora em uma } \\
\text { escola de ensino fundamental }\end{array}$ & $\begin{array}{l}\text { ETD: Educação } \\
\text { Temática Digital, v. } \\
12 \text { (esp.), p.227-251, } \\
2011\end{array}$ \\
\hline $\begin{array}{l}\text { Bruce R. Fehn e James } \\
\text { E. Schul }\end{array}$ & $\begin{array}{l}\text { Teaching and learning competent } \\
\text { historical documentary making: } \\
\text { lessons from national history day } \\
\text { winners }\end{array}$ & $\begin{array}{l}\text { History Teacher, v. } \\
45, \text { n. 1, p. 25-43, } \\
2011\end{array}$ \\
\hline $\begin{array}{l}\text { Matthew Kearney, } \\
\text { Glynis Jones e Lynn } \\
\text { Roberts }\end{array}$ & $\begin{array}{l}\text { An emerging learning design for } \\
\text { student-generated "ivideos" }\end{array}$ & $\begin{array}{l}\text { Teaching English } \\
\text { with Technology, v. } \\
12, \mathrm{n} .2, \text { p.103-121, } \\
2012 \\
\end{array}$ \\
\hline $\begin{array}{l}\text { Inês A. M. M. George; } \\
\text { Maria F. B. Martins }\end{array}$ & $\begin{array}{l}\text { Performances: desenho, literatura, } \\
\text { teatro e produção audiovisual }\end{array}$ & $\begin{array}{l}\text { Revista Matéria- } \\
\text { Prima, v.2, n. 4, p. } \\
109-114,2014\end{array}$ \\
\hline Olga Ivashkevich & $\begin{array}{l}\text { Engaging a prosumer: preservice } \\
\text { teachers interrogate popular toys } \\
\text { through stop-motion animation }\end{array}$ & $\begin{array}{l}\text { Art Education, v. } 68 \\
\text { n. } 2 \text {, p. } 42-47,2015\end{array}$ \\
\hline Walter O'Brien & Making molecular movies & $\begin{array}{l}\text { Science Teacher, v. } \\
82 \text {, n. } 4 \text {, p. 29-34, } \\
2015\end{array}$ \\
\hline $\begin{array}{l}\text { Dorotea Frank Kersch; } \\
\text { Renata Garcia Marques }\end{array}$ & $\begin{array}{l}\text { Saímos do cinema de alma lavada: } \\
\text { multiletramentos e trabalho } \\
\text { interdisciplinar na produção de curtas }\end{array}$ & $\begin{array}{l}\text { Trab. Ling. Aplic., } \\
\text { Campinas, n. 55.1, p. } \\
\text { 77-99, jan./abr. } 2016\end{array}$ \\
\hline
\end{tabular}

Destaco aqui dois artigos que se mostraram mais relevantes para dialogar com esta pesquisa (Garbin, 2011; Pereira \& Barros, 2010) e, em seguida, apresento outros oriundos de buscas mais livres em periódicos que tratam do tema.

O artigo de Pereira \& Barros (2010) apresenta um projeto de produção de vídeos de curta duração feitos por estudantes, em três turmas de uma escola do Rio de Janeiro, como estratégia alternativa para aprendizagem de física. Questionando o laboratório de física como único potencializador no processo de ensino de conceitos dessa disciplina, os pesquisadores apontam a produção de vídeos com os estudantes como alternativa para o processo experimental necessário no estudo de ciências. A proposta era de que grupos de quatro alunos produzissem um vídeo que apresentassem atividades simples sobre um 
assunto já estudado pela turma, mostrando grandezas físicas envolvidas, obtenção de dados qualitativos e/ou quantitativos e uma explanação. Foram produzidos 14 vídeos com experimentos realizados pelos alunos.

Como resultados, os autores perceberam que os alunos ficaram mais motivados a explorar o trabalho prático-experimental nas suas diversas etapas, trabalhando conceitos físicos nas observações e explanações sobre as situações que estavam gravando em vídeo. Em suas conclusões, Pereira \& Barros (2010, p. 4408) entendem que:

[...] a diferença entre o papel do trabalho experimental quando realizado pelo aluno na aula tradicional de laboratório que, via de regra, é um processo linearorientado e na produção de um vídeo, estratégia vantajosa em relação a anterior não somente pelo caráter conjuntural e motivacional, mas principalmente pelos aspectos recursivo-reflexivo e experimental-tecnológico que favorecem a cognição.

Essa proposta entende a produção audiovisual como recurso para aprender um conteúdo específico; a diferença desse tipo de tarefa para aquela atividade realizada no laboratório de física está na gravação dos processos pelos alunos. Os vídeos foram analisados pelos pesquisadores com base em referenciais utilizados na área de física para o trabalho experimental e para os aspectos da representação epistemológica dos estudantes. Nesse caso, os pesquisadores lançaram mão de uma proposta diferente para estimular os alunos, pois além do experimento, eles deveriam filmar os processos, o que demandava outras atividades que não estavam dentro de sua prática no laboratório. Esse recurso geralmente tem êxito até certo ponto, enquanto ainda é uma novidade entre os estudantes, como salienta Labrunie (2017), ao comentar que os alunos muitas vezes preferem fazer testes ao invés de produzir vídeos em atividades "valendo nota".

Em seu artigo, Garbin (2011) analisa a colaboração entre alunos e professores na realização de um vídeo educativo em uma escola pública de Campinas, com alunos do II ciclo do ensino fundamental e do ensino médio. A autora discute a influência das tecnologias na aprendizagem, considerando que estas promovem certas mudanças referentes às interações e colaborações interpessoais, tão importantes para o homem que se desenvolvem por meio das relações estabelecidas com o meio ambiente e com os outros. A autora se baseia nos conceitos de cooperação, colaboração, interação e mediação para tratar da aprendizagem colaborativa por meio do uso de tecnologias, mais precisamente do audiovisual, naquilo que chama de "pedagogia comunicacional interativa": 
[...] que coloca o professor como autor de seu conteúdo, sem que tenha que submeter-se a profissionais de outras áreas para produzir seu material. O professor tem a autonomia da produção, desenvolvendo-a de acordo com sua necessidade, criando conteúdos com seus alunos de forma colaborativa. (Garbin, 2011, p. 240).

O artigo relata como se deu o processo de construção de um vídeo educativo feito em parceria com alunos e professores, cujo objetivo era "contextualizar a história da escola e do local onde está inserida, traduzindo a visão que seus novos e antigos moradores têm sobre sua constituição e seu desenvolvimento." (Garbin, 2011, p. 241).

$O$ foco da pesquisadora foi o processo colaborativo entre as partes envolvidas nessa produção, durante os encontros presenciais. Ela indica como as trocas entre alunos e professores e entre alunos e alunos se configuraram como práticas que envolviam: colaboração (reuniões para organização do projeto e uso das tecnologias para a construção do vídeo, entre outros) e cooperação (trabalhos desenvolvidos em grupos), sendo ambos perpassados pela mediação e interação entre os envolvidos. Garbin (2011) destaca o professor como importante mediador na relação dos alunos com as tecnologias e com as informações disponíveis nas diversas mídias.

Maheirie et al. (2014, p. 85) abordam a produção de um material audiovisual, por crianças, em oficinas de vídeo. Tendo como ponto de partida a ideia de que "processos psicológicos complexos participam da criação de qualquer ordem e, no caso aqui analisado, apontam-se a percepção, cognição, memória e imaginação." (p. 85), os autores destacam que no processo de produção do vídeo houve mudança de percepção das meninas que participaram da edição de imagens, em oficinas realizadas anteriormente. Os vídeos foram produzidos em oficinas de arte e educação promovidos por uma ONG na cidade de Florianópolis. Os pesquisadores destacam que a participação nessas atividades viabilizou outras possibilidades de ser para as crianças, uma vez que a desconstrução de sentidos na relação com as imagens se constituiu em um processo estético; as meninas se dedicaram de forma mais efetiva às criações artísticas vinculadas a vivências pessoais. Por fim, Maheirie et al. (2014, p. 90) concluem que:

As experiências de aprendizado das técnicas artísticas, de criação musical e produção do espetáculo e do vídeo servem de base para a criação em uma ampla variedade de aspectos na vida dessas crianças, pois retiraram das experiências a lição de que aprender não é fácil. A satisfação experimentada ao ver e apresentar o produto desses aprendizados deve servir como ponto mediador para que se empenhem em novos aprendizados, sejam eles artísticos, científicos ou cotidianos. Foram inúmeras as "alegrias" vividas após o esforço de aprendizado e 
criação, tais como apresentar-se na comunidade para suas famílias e para novas pessoas, bem como conhecer outros espaços e fazer amigos.

Essa reflexão a respeito de passar pelas preocupações que permeiam cada etapa das oficinas até o alívio de finalizar as tarefas para as quais foram desafiados durante todo o ano é relevante para a discussão sobre a importância da finalização do filme nos processos de produção audiovisual na escola, tema que será discutido neste trabalho.

Ao ampliar o levantamento de artigos sobre experiências de produção audiovisual desenvolvidas na escola, encontrei algumas pesquisas internacionais que atendiam ao foco desta revisão e destaco aquelas que considerei mais relevantes para este trabalho.

Sun, Wang \& Liu (2017) apresentam uma pesquisa-ação realizada em Taiwan com 247 alunos do $3^{\circ}$ ano do ensino fundamental, sem experiência anterior com esse tipo de atividade, que produziram vídeos usando a técnica stop motion. De acordo com os autores, no oriente apenas nos últimos anos se iniciaram as discussões sobre a importância de formação para as mídias dentro da escola. Na análise dos filmes produzidos pelos alunos, os autores consideram que além de aprender a técnica em si, houve uma melhora em suas habilidades midiáticas para representarem suas ideias e se comunicarem. Além disso, a pesquisa considera a produção de vídeos como um caminho promissor para o fomento da alfabetização digital de alunos da educação primária. Os autores analisam a maneira como os participantes se envolveram nas tarefas propostas, comparando as atitudes de meninas e meninos nesse aspecto.

O artigo de Hobbs \& Moore (2014) faz um levantamento histórico sobre a produção audiovisual nas escolas dos Estados Unidos durante o século XX. Ressaltando o recente interesse dos pesquisadores norte-americanos sobre 0 tema, os autores revelam como a produção audiovisual acontecia em diversos níveis de formação e destacam que desde a década de 1920 o movimento de educação cinematográfica está em ascensão, criando novas oportunidades para os educadores usarem o filme não apenas como meio de transmitir conteúdo, mas como uma ferramenta para expressão criativa e de comunicação. A partir de então, diversas foram as experimentações de ensino com auxílio da produção audiovisual por jovens e crianças, como documentários para experimentações antropológicas (1960) e o uso da televisão para produções educacionais locais (1960-70). Os autores indicam que, já na década de 1970, "os esforços começaram a se concentrar em possibilitar aos jovens experimentarem o cinema 
como meio de promover o engajamento pessoal e cívico, bem como a compreensão cultural, incluindo um exame do ambiente cultural criado pela mídia de massa." (Hobbs \& Moore, 2014, p. 24). Por fim, analisam a produção de dois filmes no projeto Cinekyd, desenvolvido por Robert J. Clark, com crianças e jovens de 9 a 17 anos, que funcionou de 1970 até 2005, cuja proposta era a criação de filmes por crianças e adolescentes depois das aulas ou durante as férias:

De 1970 a 1975, Robert J. Clark trabalhou como líder de um programa de enriquecimento acadêmico apoiado pelo Distrito Escolar de Upper Moreland (UMSD). Em 1976, ele desenvolveu o Cinekyd, um programa de mídia para jovens como um pequeno negócio, no qual os pais pagavam uma taxa para matricular seus filhos em um programa de produção de filmes pós-escolares ou de verão. $O$ último programa durou mais de 20 anos, atingindo milhares de crianças em toda a comunidade. Regionalmente, Clark foi amplamente reconhecido como líder em educação de mídia nos anos 90 , mas sua carreira terminou abruptamente no início dos anos 2000. ${ }^{21}$ (Hobbs \& Moore, 2014, p. 26).

Esse artigo é de grande importância para o debate acerca das diferentes metodologias aplicadas nesse tipo de curso, sobretudo porque indica e sistematiza dois modos distintos de pedagogia de produção de mídia em contextos educacionais. Além disso, o perfil do professor Clark, sua maneira de trabalhar com os jovens, o tempo investido por ele nesse projeto, os problemas enfrentados na produção dos filmes, entre outras coisas, têm muitas semelhanças com o que observei no contexto empírico desta pesquisa.

Embora esteja fora do recorte de tempo estabelecido para esta revisão de literatura, a pesquisa de Kearney \& Schuck (2005), da Faculdade de Educação da University of Technology de Sydney-Austrália, foi incluída por oferecer contribuição relevante para análise da produção audiovisual na escola. Os autores consideram que as pesquisas sobre o tema geralmente se restringem à descrição dos processos de produção de vídeos e não consideram o papel do professor, a percepção dos alunos, entre outros aspectos pedagógicos, como os resultados da aprendizagem alcançada nessa experiência. Eles escolheram cinco escolas (duas de ensino fundamental e três de ensino médio), conhecidas como implementadoras de práticas inovadoras e empolgantes de criação de vídeos digitais por alunos. Nas visitas às escolas, aplicaram um questionário aos

21 Tradução minha do original: "From 1970 to 1975, he worked as the leader of an academic enrichment program supported by the Upper Moreland School District (UMSD). In 1976, he developed Cinekyd, a youth media program as a small business, where parents paid a fee to enroll their children in an afterschool or summer film production program. The latter program lasted for more than 20 years, reaching thousands of children across the community. Regionally, Clark was widely recognized as a media education leader throughout the 1990s but his career ended abruptly in the early 2000s." 
professores e diretores sobre infraestrutura e situação demográfica da escola; observaram e filmaram oficinas de produção de vídeos; entrevistaram alunos e professores, em grupos focais, sobre as experiências em curso e anteriores com a produção de vídeos na escola. Como resultados, os autores consideram que atividades de produção de vídeos bem projetadas estão alinhadas a princípios de aprendizado autêntico e independente, inclusive de conceitos curriculares. Segundo eles, os processos observados na pesquisa estão centrados nos alunos e são bem contextualizados, o que incentiva a participação ativa do grupo; as tarefas analisadas desenvolveram nos alunos atitudes de flexibilidade e escolha, criando um forte senso de propriedade, autorregulação e beneficiando a autoestima deles e interesse pessoal em determinados temas; os alunos projetaram suas personalidades de maneiras únicas e criativas, especialmente quando estavam cientes de seus pares como o público-alvo de suas produções.

Kearney \& Schuck (2005) indicam que a maioria dos professores participantes da pesquisa inicialmente começou a usar o vídeo digital para uso próprio e, durante esse processo, tomou conhecimento do valor da ferramenta para seus alunos. Eles lançavam mão dessa ferramenta em suas aulas a partir de interesse pessoal por vídeos digitais. A pesquisa constatou que havia uma forte crença dos professores de que o trabalho com vídeos poderia levar a um aprendizado de grupo ativo e independente, promover a criatividade do aluno e uma abordagem experimental para o aprendizado. Eles percebiam o vídeo como uma maneira de seduzir as turmas e o potencial de envolvimento dos estudantes nas próprias produções, especificamente os alunos mais problemáticos. Os professores indicaram, ainda, estar cientes em relação às novas habilidades de alfabetização digital aprendidas através do trabalho com vídeos. Em geral, essas expectativas estavam fortemente alinhadas com os resultados de aprendizagem dos alunos de suas disciplinas, pois os professores também mencionaram o valor que essa atividade tinha em gerar uma compreensão conceitual mais profunda dos tópicos do currículo. Esse último aspecto, conforme os autores, não foi observado com tanta intensidade nos resultados de aprendizado que emergiram dessas atividades. Essa pesquisa dialoga com a presente tese, pois indica uma série de habilidades desenvolvidas no processo de produção audiovisual e será relevante na construção teórico-analítica das habilidades que os estudantes da oficina demonstraram durante as observações do trabalho de campo. 
Por fim, empreendi uma busca nos sites das reuniões da Associação Nacional de Pós-Graduação e Pesquisa em Educação (Anped) sobre trabalhos encomendados ou apresentados nos grupos de trabalho (GT) de Educação e Comunicação (16) e no de Artes (24). Inicialmente considerei os textos apresentados na $33^{\underline{a}}$ até a $37^{a}$ reunião, no período de 2010-2015 e não encontrei nenhum artigo que tratasse de produção audiovisual na escola. Há trabalhos apresentados em reuniões ocorridas nos anos de 2004 a 2008, época em que o GT 16 - Educação e Comunicação discutiu a inserção do cinema na escola com olhar voltado para questões como mídia-educação em contextos formativos (Fantin, 2004, 2006; Leite, 2006), pesquisa com crianças (Honorato et al., 2006), cinema e psicanálise (Roure, 2007) e propostas de cinema na escola na França e em Barcelona (Fresquet, 2008).

Com base na descrição dos trabalhos encontrados, concluo que a quantidade de pesquisas e publicações sobre produção audiovisual na escola demonstra que o tema está na pauta de grupos de pesquisas ${ }^{22}$ e de instituições educativas, como o British Film Institute, o Centre de liaison de l'enseignement et des médias d'information (Clemi), o Centro di Ricerca sull'Educazione ai Media all'Innovazione e alla Tecnologia (Cremit), e o Nordicom Information Centre for Media and Communication Research (Nordicom) ${ }^{23}$ por exemplo, que se ocupam em recolher estudos sobre o tema e promover discussões sobre os ganhos e avanços dessa prática integrada ao currículo escolar para o desenvolvimento dos envolvidos, tanto alunos como professores.

22 Sobre os grupos de pesquisa brasileiros, destaco o Cinead: cinema para aprender e desaprender (2006), coordenado por Adriana Fresquet (UFRJ); Cinestésico: cinema e educação (2008), coordenado por Virgínia de Oliveira Silva (UFPB) e Marília Campos (UFRRJ). Além disso, listo os nomes de "alguns professores que estudam e pesquisam sobre cinema e educação há certo tempo, além de outros temas: Milene de Cássia Silveira Gusmão (Universidade Estadual do Sudoeste da Bahia), Virgínia de Oliveira Silva (Universidade Federal da Paraíba), Inês Assunção de Castro Teixeira (Universidade Federal de Minas Gerais), Maria Teresa de Assunção Freitas (Universidade Federal de Juiz de Fora), Monica Fantin (Universidade Federal de Santa Catarina), Nilda Guimarães Alves e $\mathrm{M}^{\underline{a}}$ da Conceição Silva Soares (Universidade do Estado do Rio de Janeiro), Valeska Fortes de Oliveira (Universidade Federal de Santa Maria), Ma Carla Corrochano (Ufscar), Rosa $M^{\underline{a}}$ Bueno Fisher e $\mathrm{M}^{\mathrm{a}}$ Carmen Silveira Barbosa (Universidade Federal do Rio Grande do Sul), Solange Straube Stecz (Universidade Estadual do Paraná), Carlos Eduardo de Albuquerque Miranda e Wenceslao Machado de Oliveira Jr. (Unicamp), Aristóteles Berino (Universidade Federal Rural do Rio de Janeiro), César Donizetti Pereira Leite (Unesp), Pedro Garcia e Antonio Flávio (UCP-RJ), Antonio Carlos Amâncio e Cezar Migliorin (Universidade Federal Fluminense), entre outros." (Fonseca, 2016, p. 47, 52).

${ }^{23}$ Clemi é uma agência ligada ao Ministério da Educação da França, responsável pela educação para a mídia em todo âmbito nacional (https://www.clemi.fr/). Cremit é um centro de pesquisas italiano ligado à Università Cattolica del Sacro Cuore, de Milão, que promove cursos e apoia escolas em relação à formação para a mídia (http://www.cremit.it). Nordicom é uma organização sem fins lucrativos, criada na década de 1970, e ligada à Universidade de Gutemburgo. Apoiada pelo Ministério da Cultura da Suécia, engloba todos os países nórdicos da Europa e tem por fim pesquisar e publicar sobre o uso de mídias nesses países (http://www.nordicom.gu.se/). Acesso em: 10 jan. 2019. 
Outro destaque sobre as pesquisas aqui apresentadas é que muitas delas são desenvolvidas pelas próprias pessoas que promovem as práticas (pesquisaintervenção ou pesquisa-ação), o que demonstra a necessidade de ampliar as investigações que observam tais atividades "de fora", sem o envolvimento com a prática em si, com vistas à ampliação e diversificação do conhecimento produzido nesse campo. Das seis teses aqui apresentadas, apenas Pacheco (2015) e Labrunie (2017) empreenderam investigações sobre produções audiovisuais na escola, sem estarem diretamente envolvidas no processo pesquisado. Esse dado indica que a pesquisa sobre esse tema está sendo realizada principalmente por aqueles que dirigem o processo de produção de vídeos em contextos educativos.

A literatura revisada indica que as pesquisas sobre produção audiovisual geralmente partem da crença na potência do audiovisual para a discussão de temas específicos e envolvimento dos alunos nas atividades, pois os realizadores acreditam que os alunos se interessam mais por esse tipo de proposta. Essas pesquisas e outras que tratam desse tema (Menezes, Adrião e Rios, 2017; Sulzbach, 2014) parecem indicar que a produção audiovisual é mais frequentemente utilizada como "instrumento de sedução" dos estudantes para tratar de temas curriculares ou transversais do que para a literacia audiovisual ou formação estética, funcionando como um "atrativo" para trazer os jovens para a oficina que, por sua vez, aborda pouco as especificidades da linguagem audiovisual em si. 


\title{
Pedagogia audiovisual e habilidades sociocognitivas
}

\author{
Toda pedagogia deve ser adaptada às crianças e \\ aos jovens que ela visa, mas nunca em detrimento \\ do seu objeto. Se ela não respeita seu objeto, se \\ ela o simplifica ou o caricatura em demasia, \\ mesmo com as melhores intenções pedagógicas \\ do mundo, ela faz um trabalho ruim. Sobretudo no \\ caso do cinema, em que as crianças não \\ esperaram que se Ihes ensinassem, como se diz, \\ a "ler" os filmes para serem espectadores que se \\ vivenciam como totalmente competentes e \\ satisfeitos, antes mesmo de qualquer \\ aprendizagem. (Bergala, 2008, p. 25).
}

Em nossa cultura, somos permanentemente atravessados pelas mídias audiovisuais. Mas repetir que vivemos em um mundo mediatizado não nos serve de muita coisa, como alerta Martín-Barbero (2000, p. 53), se essa reflexão não servir para pensarmos no quanto o domínio da tecnologia está a serviço de poderes que se articulam contra sistemas democráticos, aumentando ainda mais as diferenças sociais nos países subalternizados, como o Brasil:

[...] o ponto de partida para se pensar as relações da educação com a comunicação está aqui: na centralidade que o conhecimento e a informação têm ainda em países como o nosso, nos quais existem outras necessidades estruturais, que consideramos básicas, como as da moradia e saúde para as maiorias. Essa é a trágica peculiaridade desses países, que são atravessados pelas transformações da comunicação e da informação enquanto a divisão social cresce e a precária classe média sofre uma forte crise, tudo isso afetando seu sistema.

Trazer essa discussão para a escola, a fim de formarmos espectadorescidadãos parece urgente nesses tempos em que brasileiros questionam a veracidade de um vídeo sobre o nazismo, publicado pela Embaixada da Alemanha no Brasil, por exemplo ${ }^{24}$. Norton (2013, p. 21) considera que: "A ampliação do número de espectadores que compreendem a linguagem audiovisual é um fator importante para a difusão e a democratização desse meio." E questiona: "Como introduzir uma leitura diferenciada do audiovisual quando os alunos já se consideram espectadores plenos?" Nos dias atuais,

24 Publicado em: https://www.facebook.com/EmbaixadaAlemanha/videos/1658739200897794/. O caso foi abordado em diversos meios de comunicação brasileiros e internacionais: https://congressoemfoco.uol.com.br/direitos-humanos/brasileiros-contestam-video-da-embaixadaalema-sobre-o-nazismo/; https://brasil.elpais.com/brasil/2018/09/13/politica/1536853605_958656.html; https://www.washingtonpost.com/world/2018/09/21/divisive-brazilian-election-even-nazis-are-updebate/?noredirect=on\&utm_term=.cdfabac7f7a5; https://www.bbc.com/mundo/noticias-americalatina-45583090. Acesso em: 8 jan. 2019. 
algumas crianças têm contato desde bebês com narrativas audiovisuais e com a internet, por meio de tablets e smartphones, usados como "babás eletrônicas" (Sobral, 2018). Desde muito pequenas, elas são vistas pelos pais como "superinteligentes" em relação ao manuseio de dispositivos digitais, sendo consideradas mais desenvoltas, com aplicativos e jogos em geral, do que os adultos. Essa "certeza" tornou-se senso comum, embora pesquisas - como a de Pereira et al. (2018) e de Livingstone (2011) - concluam falta de literacidade ${ }^{25}$ em relação ao uso da internet por adolescentes europeus, por exemplo. A ideia de "espectadores plenos" (Norton, 2013) e de "espectadores que se vivenciam como totalmente competentes e satisfeitos, antes mesmo de qualquer aprendizagem" (Bergala, 2008, p. 25) está baseada na experiência de crianças e jovens com os filmes, pois, desde muito cedo, são leitores dessas narrativas. Conforme afirma García-Canclini (2009, p. 216):

Os jovens atuais são a primeira geração que cresceu com a televisão em cores e o vídeo, o controle remoto, o zapping e - uma minoria - com o computador pessoal e a internet. Entre as décadas de 1970 e 1980, a pergunta era o que significava ser a primeira geração na qual a televisão era um componente habitual da vida familiar. Agora se trata de entender como a espetaculalização permanente à distância nos modifica, ou, dito de outro modo: esta estranha combinação de midiatização e interconectividade. A midiatização afasta, esfria, e, ao mesmo tempo, a interconectividade proporciona sensações de proximidade e simultaneidade. ${ }^{26}$

Talvez por se considerarem (e serem considerados pelos adultos) como "espectadores plenos" esteja tão impregnada em nossa cultura a máxima de que, na escola, quando a professora "passa filme", não dá aula. Afinal, como considerar relevante algo que não demanda do aluno nada que ele não saiba ou

25 Para Livingstone (2011, p. 21), "literacidade" envolve uma série de habilidades em um dado domínio para exploração das formas comunicativas (impresso, audiovisual, interpessoal e digital), aprendizagem e controle do que este domínio oferece e está relacionada à individualidade de cada um sobre tais habilidades que estão relacionadas a práticas sociais "possibilitadas (ou impedidas) por recursos (ou capitais) econômicos, culturais e sociais (distribuídos desigualmente)." Pacheco (2015) apresenta uma relevante discussão sobre os diversos termos usados atualmente para designar a educação e a aquisição de habilidades em relação às mídias digitais e ao relacionamento com outras pessoas por meio da internet. Nesta tese, utilizo o termo "literacia midiática" no sentido de ter competências para lidar com os equipamentos, o acesso à rede e de se relacionar com outras pessoas em ambientes virtuais.

${ }^{26}$ Em estudo realizado pela Fundação Getúlio Vargas (2018), sobre uso de equipamentos usados em maio de 2018, no Brasil, a cada 6 habitantes, 5 possuem computadores - considerando desktop, notebook e tablets; a são 174 milhões de computadores em uso no país. Em relação aos smartphones, a pesquisa aponta um total de 20 milhões no país, correspondendo a 1 por habitante. Os números de aparelhos portáteis (notebook, tablets e smartphones) é de 306 milhões de dispositivos: 1,5 por habitante. Como o Brasil é um país de grandes diferenças sociais, é preciso ter atenção ao olhar esses números e não nos enganarmos em relação à democratização do acesso aos aparelhos e à internet. Na rede municipal de ensino do Rio de Janeiro, por exemplo, considerada a maior rede da América Latina, $72,70 \%$ dos diretores consideram o acesso à internet na escola regular, ruim ou péssimo (Duarte et al., 2016). Essa realidade mostra que a escola pública brasileira ainda precisa superar problemas de infraestrutura básicos para uma educação de qualidade atividades que abordem a educação midiática na escola. 
domine? Como entender o que há de relevante em uma atividade que ele realiza em sua casa, inclusive sozinho? Ver (e muitas vezes fazer) vídeos é algo que muitas crianças de sociedades fortemente audiovisualizadas como a nossa já sabem e já fazem em sua vida diária. Assim, se tomados somente como narrativas que passam mensagens ou ilustram temas e conteúdos escolares, os filmes contribuem muito pouco com a educação:

Filmes não são decalques ou ilustrações para "acoplarmos" aos textos escritos nem, muito menos, um recurso que utilizamos quando não podemos ou não queremos dar aula. Narrativas fílmicas falam, descrevem, formam e informam. Para fazer uso delas é preciso saber como elas fazem isso. (Duarte, 2009, p. 76).

O que altera o modo como os filmes ou vídeos entram na escola é a existência de objetivos bem definidos e de uma pedagogia que oriente o trabalho a ser realizado com eles. Essa percepção tem levado pesquisadores e professores a desenvolverem o que vem sendo definido como "pedagogia audiovisual". Construída a partir de determinadas perspectivas teóricas, trata-se de metodologias que orientam a escolha dos filmes a serem exibidos em sala de aula, e de que forma fazer isso, além de atividades e objetivos que norteiam a produção audiovisual com estudantes.

Entre as possibilidades de trabalho com filmes na escola, Franco (2014, p. 87) considera que qualquer filme pode ser educativo, porém adverte que, para isso, é necessário que sejam dadas as condições para que a relação com o filme venha a modificar, de alguma forma, seu espectador:

Porque educativo não é o filme, mas é a relação que se estabelece entre o filme e o espectador que é pessoal e intransferível e também incontrolável do ponto de vista de como pode influenciar cada pessoa. Pode provocar um grande impacto modificador, que eu poderia chamar de uma "modificação educativa" para o bem e para o mal, o que corrobora com a minha concepção de que qualquer filme pode vir a ser educativo, mesmo aquele qualificado como ruim. Em função disso, entendo que no ambiente das comunicações audiovisuais nada é apenas entretenimento. Tudo corre o risco de ser educativo, entendida a educação como uma ação de modificação afetivo-cognitiva que pode ser boa ou não.

Sendo assim, ao se transformarem em objetos/instrumentos/experiências da escola, os filmes perdem seu status de entretenimento e são tomados como objeto/mídia/atividade/experiência pedagógico(a), seguindo o que mencionei anteriormente: tudo o que entra na escola passa a fazer parte dela e a estar sujeito às suas necessidades e propostas. O mesmo ocorre com a produção audiovisual. "Precisamos levar em consideração que o cinema já faz parte da educação. Talvez fosse mais exato se disséssemos que filmes fazem parte da escola." (Migliorin, 2015, p. 33). 
A partir da questão colocada por Norton (2013) sobre considerar os alunos de hoje como "espectadores plenos", pretendo apresentar o que parece constituir uma pedagogia audiovisual que efetivamente contribua para formação de jovens espectadores, direcionando meu olhar para a produção de filmes na escola. Embora crianças e jovens de hoje não possam ser considerados "produtores plenos" - pois para isso é preciso ter competências/habilidades bastante elaboradas em relação ao manejo com imagens e sons - parto da premissa de que os estudantes fazem parte de uma geração que, além de assistir, também produz imagens e vídeos, devido ao acesso facilitado a câmeras e aplicativos que demandam a publicação, principalmente na internet, de fotos, vídeos e montagens cada vez mais curtas (snapchat) e com mensagens bem diretas (memes). Estamos diante de uma crescente produção audiovisual de jovens veiculada na internet em redes sociais, como o YouTube (Area, 2012; Pires, 2010) e, como já sinalizei, houve um aumento significativo de cursos e projetos voltados para o ensino do audiovisual em espaços educativos $^{27}$.

Pensar a recepção e produção de imagens nas redes faz parte dos objetivos de uma escola de qualidade que, de acordo com Belloni (1998, p. 149), deve ensinar para as mídias "sem perder de vista os ideais humanistas da modernidade [...], mostrando-se capaz de colocar as tecnologias a serviço do sujeito da educação - o cidadão livre - e não a educação a serviço das exigências técnicas do mercado de trabalho." Livingstone (2011) ressalta a importância de a escola não ser a única responsável por essa tarefa, tendo em vista a necessária e urgente regulação da indústria midiática sobre os conteúdos por ela produzidos e veiculados e uma preocupação maior do Estado com a formação da literacidade midiática dos estudantes, pois os recursos das políticas públicas estão mais voltados ao acesso e domínio de noções básicas do que à avaliação crítica ou criação de conteúdos pelos usuários.

Para alguns estudiosos do campo de cinema e educação, o audiovisual na escola é uma questão de educação midiática (Fantin, 2014; Ferrés, 2007; Pires, 2010), enquanto para outros, trata-se de uma experiência criativa e sensível com o mundo através de filmes ou da câmera (Bergala, 2008; Fresquet, 2013, Norton,

\footnotetext{
${ }^{27}$ Leite e Alegria (2005, p. 1) informam que essa produção já se mostrava expressiva em 2004: "Durante as sessões do Panorama Mundial da $4^{a}$ Cúpula Mundial de Mídia para Crianças e Adolescentes, realizada no Rio de Janeiro, em abril de 2004, a maior parte das cerca de 80 comunicações apresentadas referiam-se a projetos de realização de mídia - principalmente audiovisuais -, 'com' e 'por' crianças e adolescentes e, muitas outras delas, tratando da produção 'para' crianças e adolescentes, relatavam tê-los incluído em algum momento do processo de realização."
} 
2013). A abordagem que faço aqui apresenta como cada uma dessas vertentes orienta sua pedagogia audiovisual, a fim de contribuir para a discussão no campo sobre as metodologias e fins dessa prática na escola, sem intenção de avaliar ou comparar tais abordagens teóricas, mas tendo em vista sistematizar algumas de suas propostas, argumentando como elas podem se complementar no processo de ensino do audiovisual na escola. Para isso, apresento inicialmente um breve panorama histórico dessa pedagogia e defendo porque esta pode ser uma tarefa também da escola.

Pretendo também discutir sobre a ideia de que o processo de ensinoaprendizagem do audiovisual, além de oferecer instrumentos para construção de um olhar crítico para as mídias e ampliação da sensibilidade estética, pode favorecer o desenvolvimento de habilidades sociocognitivas, na medida em que exige trabalho em equipe, planejamento e organização a médio prazo, capacidade de escuta, gerenciamento de projetos, capacidade de apresentação e associação de ideias, capacidade de transcodificação de linguagens (da oral para a escrita, da escrita para a imagética, do sonora para a visual, etc.) entre outras habilidades necessárias à vida social e à participação cidadã na sociedade atual. Tratarei desse tema mais à frente, neste capítulo, sintetizando uma parte dos estudos sobre o desenvolvimento dessas habilidades.

\section{1 Pedagogia audiovisual \\ * Um pouco de história}

Na obra "Pédagogie audio-visuelle: histoire e actualité", Claude ThollonPommerol (1983) questiona a paternidade do ensino com imagens, atribuída geralmente Comenius (1592-1670), por ter escrito sobre a possibilidade de usar imagens/modelos/desenhos para o ensino, pois antes disso São Tomás de Aquino (1225-1274) havia atribuído o uso das imagens para: instruir o ignorante. Tais referências ao uso de imagens no ensino podem servir para a reflexão sobre o quão antiga é a discussão a respeito dessa questão e, embora não esteja voltada diretamente ao audiovisual, esses podem ser considerados os primeiros olhares para o tema. 
Thollon-Pommerol (1983) apresenta a história da pedagogia audiovisual a partir do uso do microscópio solar (séc. XVIII) e da lanterna mágica ${ }^{28}$ (séc. XVII$X X)$. O microscópio solar é um instrumento de projeção de imagens que foi usado pedagogicamente por Abbé J. Nollet, para auxiliar no ensino de Dauphin e de Henriette-Anne, filhos do rei Louis XV e do duque de Berry, que se tornou rei Louis XVI. O professor registrou cerca de 20 experimentos com esse instrumento para fins de ensino.

Inicialmente, o uso da lanterna mágica foi condenado pelos pedagogos jesuítas por ter caráter ilusório ${ }^{29}$, tendo sido difundida como instrumento de ensino pelo padre jesuíta alemão Athanasius Kircher (séc. XVII) ${ }^{30}$ e o Conde Du Paroy (séc. XVIII) para instrução e recreação dos estudantes. Thollon-Pommerol (1983) apresenta diversos cursos promovidos entre os séculos XVIII e XIX, que contavam com dezenas de milhares de projeções de lanterna mágica em cidades europeias e nos Estados Unidos. Essa época é vista como o apogeu das projeções científicas antes da difusão do cinema.

Sobre os usos da lanterna mágica, o autor destaca a participação de S. Meunier em um congresso pedagógico no ano de 1880, com a conferência intitulada: "Les projections lumineuses et l'enseignement primaire", na qual apresentou as diversas possibilidades desse meio de ensino, desenvolvidas junto com A. Molteni. No início do séc. XX, algumas iniciativas governamentais na França, Suíça e Austrália disponibilizaram gratuitamente às escolas materiais necessários para o ensino com uso de projeções luminosas. Embora parecesse uma boa tecnologia para aprendizagem, conforme defendiam seus criadores, Thollon-Pommerol (1983) relata que a adoção dela demorou a se estabelecer nas escolas, pois com os poucos recursos disponíveis, era necessário contar com a boa vontade e esforço dos professores que precisavam usar de

28 A lanterna mágica (ou epidascópio) foi inventada no século XVII. "Era constituída por uma câmara escura e um jogo de lentes. A luz de uma lâmpada de azeite incorporada, por meio de um condensador, atravessava uma placa de vidro pintada com desenhos que eram projetados num lenço. Era possível criar a ilusão de movimento movendo os vidros." (Wikipédia, 2019). No filme Lanterne magique (1903), de George Méliès, os personagens criam uma lanterna mágica gigante de ondem saem diversos personagens (reais), demonstrando como o cinema registra sua própria história. Disponível em: https://www.youtube.com/watch?v=EtXfFyBHKJw. Outras informações sobre a lanterna mágica estão disponíveis neste blog: http://diaprojection.unblog.fr/search/lanterne+magique. Acesso dos links em: 11 jan. 2019.

29 Antes dos filmes serem inventados, os jogos óticos eram bastante populares. Sobre isso, é importante mencionar o trabalho do Cinead, intitulado "As origens do cinema: jogos ópticos" (Fresquet, s/d). Trata-se de um material didático, que apresenta a história de alguns instrumentos que antecederam o cinematógrafo (câmara escura, fenaquistoscópio, flipbook, folioscópio, taumatrópio, teatro de sombras e zootrópio), com instruções de como fabricá-los.

30 De acordo com Thollon-Pommerol (1983), há quem indique que a tecnologia da lanterna de projeção foi usada no culto de Isis, no Egito Antigo. Em uma de suas obras, Kircher questiona se o poder do rei Salomão em projetar sua imagem nas montanhas não estaria relacionado à utilização de algum tipo de lanterna de projeção. 
engenhosidade e intuição para um proveito ainda mais eficaz das imagens disponibilizadas. Isso demonstra que, possivelmente, não havia uma formação dos professores para o uso dessa tecnologia nas escolas. Uma nota jornalística de M. Thibeaud, datada de 1914, indica que apenas 5\% das escolas suíças usavam essa tecnologia, embora a maioria contasse com equipamentos disponibilizados gratuitamente pelo governo.

O ensino através das imagens chegou a ser considerado um meio de popularização da ciência, quando foi proposta. No início do séc. $X X$, foi criada uma enciclopédia específica para esse tipo de instrução que, conforme acreditava seu criador, F. David, faria as massas assimilarem rapidamente diversas ideias.

Com o surgimento do cinematógrafo houve, no início, pouco interesse dos pedagogos em relação a essa evolução tecnológica que mudaria completamente a história do cinema. Thollon-Pommerol (1983) atribui esse descaso dos professores à falta de registro do termo que nomeava a invenção no dicionário pedagógico de Ferdinand Buisson, publicado em 1911. Segundo o autor, embora desde 1913 houvesse um bom número de propostas pontuais de ensino com filmes, apenas em 1926 ocorreu o $1^{\text {er }}$ Congrès International du Cinéma Educatif, no qual foram discutidas metodologias de ensino.

Jaquinot-Delaunay foi uma das precursoras do uso do audiovisual na escola, quando ainda na década de 1960 produziu programas a serem difundidos pela Televisão Escolar (TVS - ligada ao Ministério da Educação Nacional) em toda a França. Em seguida, ela passou a levar os filmes da TVS para a escola, a fim de analisar como se dava a recepção dos conteúdos pelos alunos. Esta pesquisa resultou em um artigo apresentado no $3^{\text {ème }}$ Congrès de l'Union Européenne de Radio-Diffusion, em 1967, no qual ela aborda a questão da motivação e participação dos alunos por meio de emissões polivalentes, analisando o "processo de concepção-realização-difusão-recepção de um documento audiovisual elaborado para fins didáticos." (Jacquinot-Delaunay, 2007, p. 74). Para a autora:

[...] os elementos, sonoros ou visuais, que intervêm no plano do conteúdo das imagens e dos sons ou no plano da formatação, que se situam no nível retórico global ou no pontual de uma imagem ou de um som... Todos esses elementos são vetores de informações dadas ao espectador-aluno que deve organizar sua 
percepção e elaborar o conhecimento de acordo com uma abordagem e uma rota que são suas. (Jacquinot-Delaunay, 1977 apud Thollon-Pommerol, 1983, p. 48). ${ }^{31}$

Com base nessa citação, é possível constatar de que maneira o audiovisual era percebido no ensino, e que, provavelmente, era seguida por seus colegas à época, pois como indica a autora, todos os estímulos - sonoros e visuais, os conteúdos e a maneira de organização das mensagens - eram apresentados pelo filme aos "espectadores-alunos" que o interpretariam cada qual à sua maneira. Nesse tipo de pedagogia ainda não estavam claras as competências necessárias para alcançar os objetivos propostos, uma vez que nem todos os alunos apresentam as mesmas capacidades e, portanto, não chegariam à mesma interpretação do filme, ao final da atividade - tendo em vista que este seria o resultado esperado pelos professores. Desde essa época, havia uma preocupação dos pedagogos em não saber lidar teoricamente com as imagens, com certo receio sobre a desproporção entre a riqueza técnica disponível e o quanto se sabia e se teorizava a respeito disso em relação ao seu uso na educação, como salienta Leandro (2001, p. 31):

Já na introdução de seu livro, Jacquinot alertava quanto a uma "inquietante desproporção" entre a riqueza técnica das soluções de produção, estocagem e difusão de mensagens audiovisuais da época e a pobreza de nosso saber sobre o que são essas mensagens e como elas funcionam. Hoje essa desproporção persiste e é de se esperar que a inquietude dos educadores aumente. Com o desenvolvimento da tecnologia do vídeo, a imagem tem sido cada vez mais amplamente assimilada pela educação, sem a contrapartida de uma reflexão teórica mais aprofundada e de uma práxis mais consequente dessa mesma imagem.

Em 1974, André Malraux acreditava ser possível substituir quase integralmente o livro pela televisão, já prevendo o uso do computador para a aprendizagem dos jovens que se mostravam entediados pela leitura e apaixonados por essas novas tecnologias. Desde as primeiras experiências aqui relatadas sobre o uso do cinema na escola (desde mesmo o uso de imagens em movimento da lanterna mágica), as atividades com filmes eram (e ainda continuam, como destaquei na revisão de literatura) vistas como algo motivador, carregando a incumbência de atrair a atenção de crianças e jovens à escola e à própria aprendizagem.

31 Tradução minha do original: "[...] les éléments, qu'ils soient sonores ou visuels, qu'ils interviennent au plan du contenu des images et des sons ou au plan de la mise en forme, qu'ils se situent au niveau rhétorique global ou au niveau ponctuel d'une image ou d'un son... tous ces éléments sont des vecteurs d'information offerts au spectateur-élève qui doit organiser sa perception et élaborer la connaissance selon une démarche et un itinéraire qui lui sont propres." 
Hobbs \& Moore (2014, p. 23) apresentam o caminho da produção audiovisual na educação dos Estados Unidos ao longo do séc. $X X^{32}$, considerando que "os educadores têm um jogo e aprendizado equilibrados, fazendo uso do cinema e do vídeo como objetos de estudo e como ferramentas de expressão e comunicação." 33 Porém, destacam a dificuldade de conseguir esse equilíbrio, pois o interesse de estudiosos em registrar a história do ensino sobre cinema e mídia no país é recente, enquanto as práticas se iniciaram na década de 1940, conforme sintetizo no quadro a seguir:

\footnotetext{
32 Embora seja uma realidade distante da brasileira, entendo que conhecer os diversos caminhos que a produção audiovisual percorre em outros lugares pode ser relevante na compreensão do nosso próprio percurso. Trago a explanação da história nos Estados Unidos apenas para uma visualização de seus interesses e práticas, sem esquecer que há outras histórias relevantes de países mais próximos, como a Argentina e o Chile, por exemplo. Essa escolha se deu mais por uma questão prática, pois os autores surgiram entre os textos de levantamento bibliográfico, do que especificamente por uma maior relevância na história da pedagogia audiovisual em relação a outras pedagogias mundo afora.

33 Tradução minha do original: "[...] educators have balanced play and learning in making use of film and video both as objects of study and as tools of expression and communication."
} 


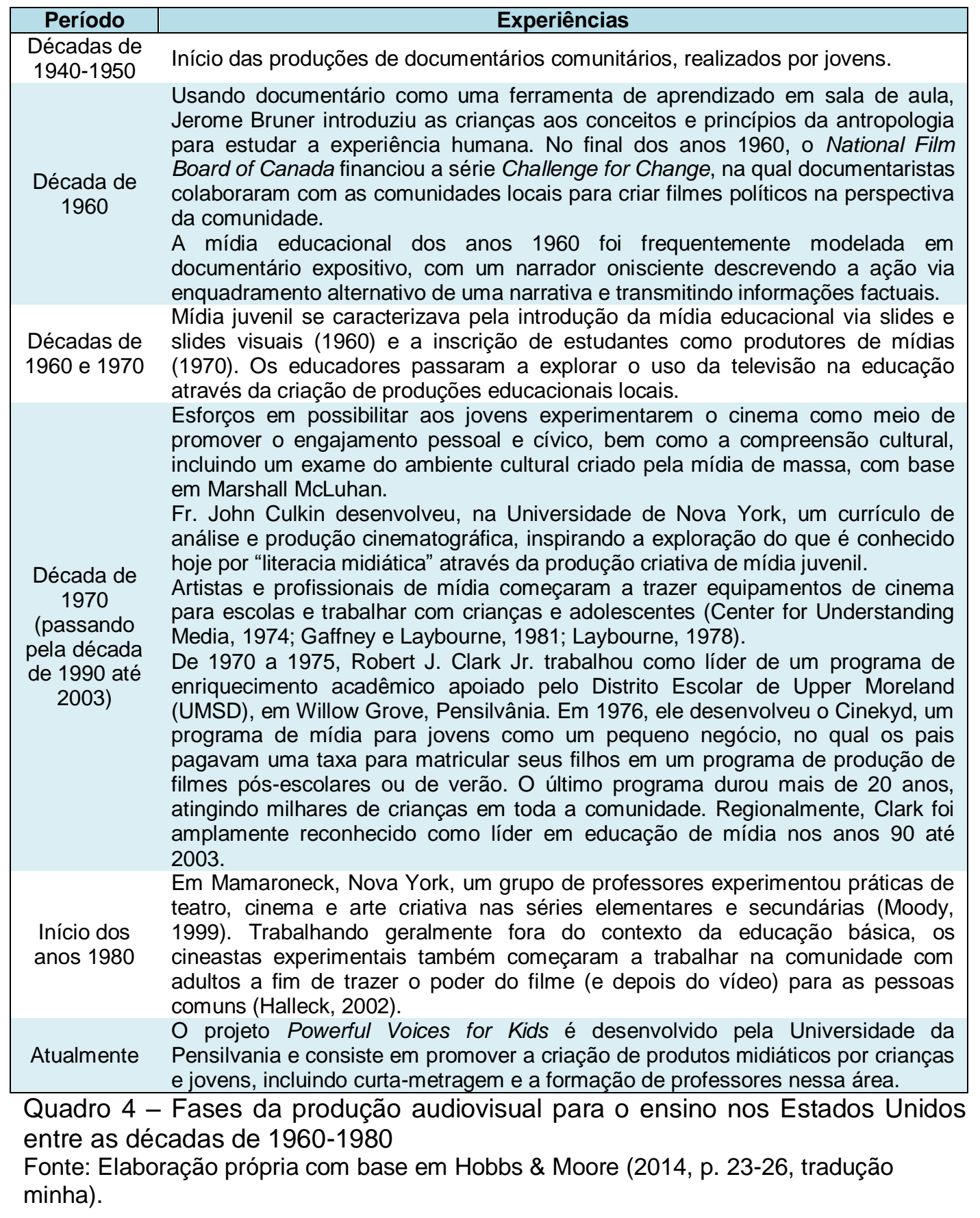

Os autores consideram que a ascensão do movimento de educação cinematográfica criou novas oportunidades para os educadores não apenas usarem o filme como meio de transmitir conteúdo, mas também como uma ferramenta para expressão criativa e comunicação. 
No contexto brasileiro, os registros sobre o uso do cinema com viés educativo datam de 1910, cujo percurso teve as seguintes ações e objetivos ${ }^{34}$, entre outros:

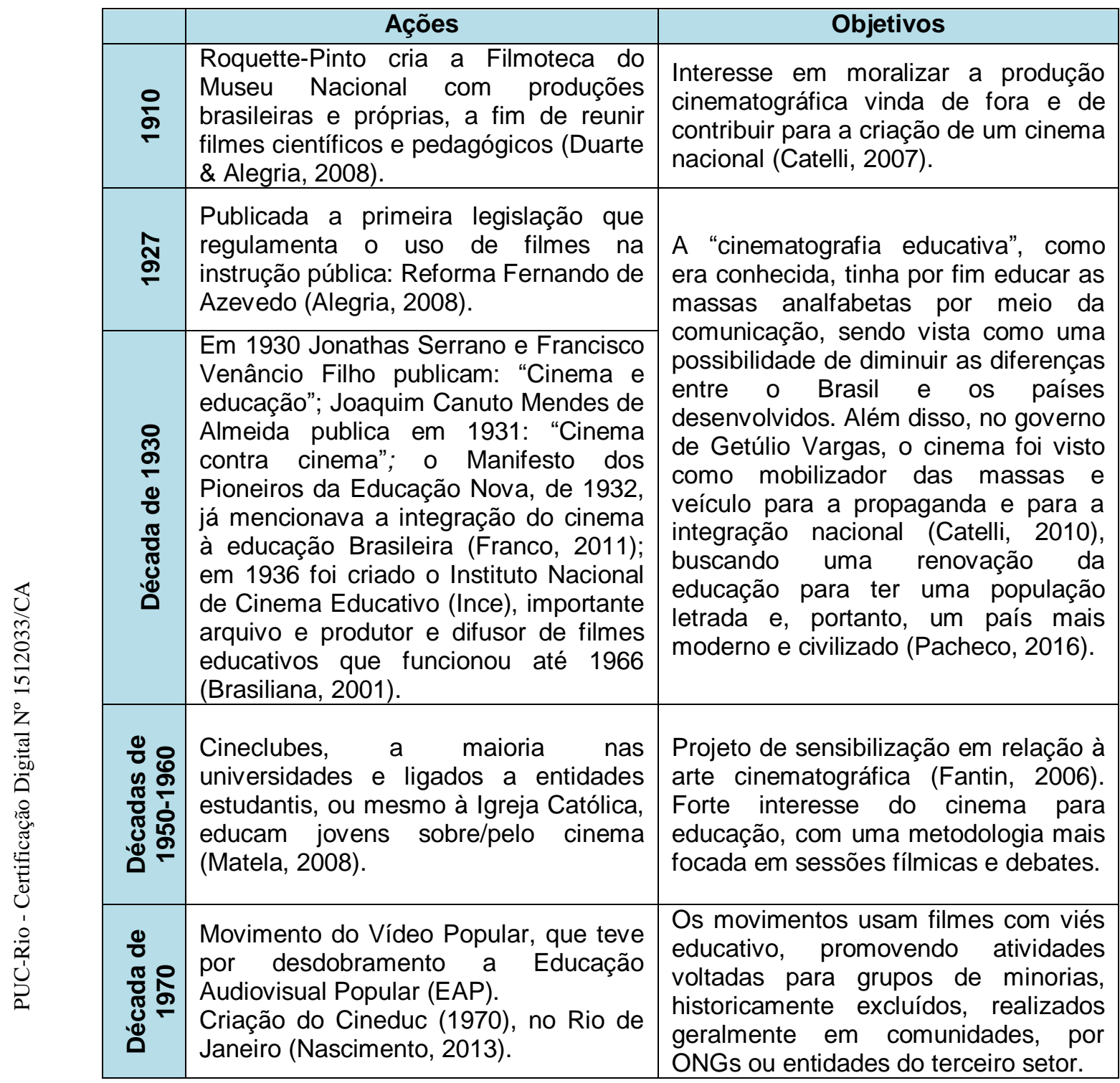

\footnotetext{
${ }^{34}$ Abordo os fatos aqui elencados em um levantamento histórico do cinema educativo no Brasil, publicado no artigo: "Cinema na escola pra quê?" (Fonseca, 2016).
} 


\begin{tabular}{|c|c|c|}
\hline 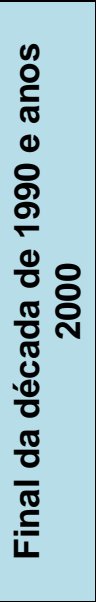 & $\begin{array}{l}\text { O cinema brasileiro ganha maior } \\
\text { notabilidade nacional } \\
\text { internacionalmente com os filmes } \\
\text { Cidade de Deus, Carandiru e Central do } \\
\text { Brasil. O governo Lula passa a investir } \\
\text { na indústria cinematográfica, o que } \\
\text { acarreta maior difusão do cinema nas } \\
\text { escolas por projetos desenvolvidos } \\
\text { pelas secretarias municipais ou } \\
\text { estaduais de educação, com } \\
\text { apoio/assessoria de empresas ligadas } \\
\text { ao audiovisual, chegando mais } \\
\text { recentemente a projetos de âmbito } \\
\text { federal, com apoio de universidades } \\
\text { (Fonseca, 2016). }\end{array}$ & $\begin{array}{l}\text { Forte presença de atividades } \\
\text { baseadas na exibição de filmes na } \\
\text { escola com diversos objetivos: abordar } \\
\text { temáticas e datas comemorativas, } \\
\text { ilustrar conteúdos e promover debates } \\
\text { sobre diversos temas, curriculares ou } \\
\text { não. Em seguida, houve um } \\
\text { movimento de criação de cineclubes } \\
\text { nas escolas e início de projetos (pouco } \\
\text { frequentes, mas presentes) de } \\
\text { produções audiovisuais de alunos. }\end{array}$ \\
\hline 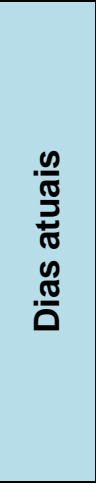 & $\begin{array}{l}\text { A exibição de filmes continua como } \\
\text { prática mais forte (Duarte et al., 2016) e } \\
\text { assim como a produção de filmes em } \\
\text { espaços educativos toma maior } \\
\text { proporção, as pesquisas sobre esses } \\
\text { processos também aumentam. Tal } \\
\text { mudança se deve, em parte, à } \\
\text { divulgação desses filmes em mostras } \\
\text { de cinema e a investimentos públicos } \\
\text { nessas atividades com criação de } \\
\text { projetos de cineclubes nas escolas, } \\
\text { entre outros (Fonseca, 2016). }\end{array}$ & $\begin{array}{l}\text { Divulgar as atividades e projetos } \\
\text { escolares, inserir os filmes nas } \\
\text { atividades ligadas ao currículo de } \\
\text { artes, promover oficinas no } \\
\text { contraturno, participar de festivais, } \\
\text { ganhar equipamentos para a escola, } \\
\text { atender demandas voltadas ao uso de } \\
\text { mídias das secretarias de educação, } \\
\text { entre outros. }\end{array}$ \\
\hline
\end{tabular}

Quadro 5 - Breve panorama histórico das ações com cinema nas escolas brasileiras e seus objetivos

Fonte: Elaboração própria.

No Brasil, a partir dos anos 2000, a popularização dos aparelhos e filmes de DVD nas escolas facilitou a exibição de filmes, além de baratear os custos, pois já era possível copiar os filmes com auxílio do computador - prática comum até hoje. O uso de filmes para ilustrar conteúdos é criticado por alguns estudiosos do campo e aceito por outros. Leandro (2001, p. 29) considera tal uso das imagens um equívoco, referindo-se àquele feito na década de 1960, através do que era conhecido como "pedagogia do transporte":

Um equívoco leva a outro: por ser abordada como ilustração, como mera referência a um discurso que a precede, o discurso pedagógico, a imagem acaba tendo uma participação secundária na maioria dos processos educativos que a utilizam. Prevalece ainda hoje aquela "pedagogia do transporte", da "mensagem a ser transmitida", permitindo que essa imagem continue sendo absorvida pela educação sem maiores exigências formais. $O$ desinteresse pela ontologia desse novo objeto do qual a educação se apropria tem levado a uma espécie de democratismo visual onde todas as imagens se equivalem, desde que a intenção pedagógica seja assegurada.

Duarte (2009) compara o ato de ver filmes à leitura de obras literárias e filosóficas, entre outros saberes, a partir do ponto de vista cultural e educacional, questionando: "Até quando ignoraremos o fato de que cinema é conhecimento?" 
Essa questão foi respondida por Livingstone (2011), ao denominar - baseada em Gunther Kress - essa falta de atenção às imagens de "cegueira cultural para as imagens" cuja causa estaria no domínio do impresso em nossa cultura. Ao pensarmos na importância que as imagens (audiovisuais ou não) têm em nosso tempo, podemos considerar que a maior parte das políticas educacionais ainda estão baseadas nessa cegueira.

O interesse da pedagogia audiovisual estava inicialmente na visualização/análise/recepção de filmes a partir de uma ampliação da "competência para ver" (Duarte, 2009), modificada a partir dos filmes assistidos na escola. Ampliando essa proposta para a produção audiovisual, passou-se a buscar a modificação do olhar através da câmera (Norton, 2013; Fresquet, 2013) a partir das potências pedagógicas da criação cinematográfica (Aidelman \& Colell, 2011) na experiência com o ponto de vista e com os planos, entre outras, conforme a proposta de Alain Bergala. Paralelamente, o campo da mídiaeducação privilegiou a análise crítica dos discursos audiovisuais e dos interesses por trás das mensagens construídas, dentro da perspectiva das multiliteracies:

\begin{abstract}
O desafio é trabalhar a alfabetização, o letramento e/ou a linguagem audiovisual no contexto das multiliteracies como uma condição para um trabalho significativo com o cinema e audiovisual na escola. Para isso enfatizamos, mais uma vez, que é fundamental apropriar-se dos códigos audiovisuais e produzir sentidos a partir da narrativa fílmica; identificar e reconhecer os elementos da esfera visiva (luz, cor, campo, planos; movimento dos personagens e das máquinas; cenografia; efeitos especiais; escrita; montagem) e da esfera auditiva (sons, falas, diálogos; ruídos, música) como competências necessárias para entender e se expressar audiovisualmente ao lado das demais linguagens. (Fantin, 2014, p. 62-63).
\end{abstract}

Para a mídia-educação, tais competências podem ser construídas pela escola, tendo em vista a urgência em capacitar jovens e crianças para lidarem com as tecnologias digitais de forma crítica, sendo esta mais uma função da escola.

A partir do percurso aqui apresentado, é possível considerar que até o final do século $X X$, a pedagogia audiovisual estava mais voltada aos processos de recepção de filmes analisados em sala de aula, ou cujo conteúdo servia de suporte para ilustrar temas tratados nas disciplinas, com exceção da experiência com a produção nos Estados Unidos, iniciada na década de 1970.

Nos dias de hoje, o interesse da escola em relação ao audiovisual tem se baseado principalmente na massificação da comunicação via redes sociais, por meio das quais compartilhamos materiais audiovisuais, por conta da popularização dos meios de captação de imagens em dispositivos móveis. Professores buscam estratégias para motivar os estudantes a aprenderem 
matérias escolares com o uso das mídias, ou para educá-los para as mídias, tendo em vista a hiperconectividade de crianças e jovens e o grande interesse deles (e de todos nós) pela comunicação on-line, via redes sociais, vídeos e jogos na internet. De acordo com Pereira (2000, p. 2), a educação para as mídias relaciona-se à necessidade e à importância:

[...] do sistema educativo promover a formação de consumidores críticos que não se deixem "empanturrar de" ou "afogar na" informação. É fundamental saber o que fazer com tanta informação, aprender a controlá-la, saber filtrá-la e usá-la. E aqui a questão que se coloca é a de saber se as crianças estão a aprender sobre estas matérias; se as instituições educativas, formais e informais, estão a dar a devida importância a este fenómeno; se têm procurado ajudar as crianças, mesmo as que ainda não têm permissão para atravessar a rua do bairro em que vivem, a atravessar, de forma crítica e autónoma, o planeta que os media lhes oferecem.

O quanto (e para quem) é relevante (ou não) uma educação voltada para a compreensão e interpretação das imagens como elas se apresentam na sociedade atual? Compreender as intenções por trás da montagem de imagens e sons, ou a recorrência de frases de efeito e focos repetitivos pode ajudar crianças e jovens em quê, na construção do conhecimento? A manipulação de notícias e a disseminação de fake news nas redes sociais, que deram o tom da disputa na eleição presidencial de 2018 no Brasil, por exemplo, poderiam nos ajudar a pensar em respostas para essas questões.

A produção audiovisual por jovens e crianças na escola foi ampliada significativamente, com a difusão de aparelhos móveis e o barateamento dos processos de edição e até divulgação das produções na internet, pelas redes sociais ou nos blogs das escolas ${ }^{35}$. Acompanhando esse crescimento, as pesquisas que tratam da produção de vídeos estudantis chegaram a maior proporção na última década (Araújo, 2008; Costa, 2014; Faria, 2011; Garcia, 2010; Labrunie, 2017; Leite, 2012; Lima, 2013; Saldanha, 2016; Santos, 2008; Silva, 2015; entre outros). Isso indica que compreender a contribuição que essa prática oferece à educação escolar, ainda que não seja uma questão nova, carece de estudos. Mas o que pauta uma pedagogia audiovisual? Que metodologias a constituem?

\footnotetext{
${ }^{35}$ A rede municipal de educação do Rio de Janeiro, por exemplo, organiza no portal Rio Educa (http://www.rioeduca.net/blog.php?bid=14) uma lista com vários blogs (hospedados, em sua maioria, no Blogspot) das CREs, das escolas e de educadores da rede, nos quais são divulgadas produções e projetos realizados nas escolas. Ao seguirmos a reflexão de Livingstone (2011), podemos atribuir a boa adesão dos professores à publicação de seus projetos nos blogs, conforme é possível verificar no site, a uma extensão da cultura do impresso. Esses blogs publicam textos breves com fotos dos eventos e, em menor proporção, vídeos, podendo ser considerados como o "cartão de visitas" da escola ou, ainda, um upgrade dos quadros dispostos nos pátios das escolas em que são divulgadas as atividades ali realizadas.
} 


\section{* Pedagogias distintas: mídia-educação e cinema educação}

Ao entender por pedagogia uma forma de ensinar, com metodologias próprias e perseguindo objetivos previamente delimitados, tendo em vista a construção de determinado conhecimento, é possível levantar pistas sobre o que constitui uma pedagogia audiovisual. Em pesquisa sobre a produção de animações por professoras das escolas públicas cariocas, Milliet (2014, p. 67) analisou a "pedagogia da animação" de cada docente, compreendendo haver "gestos pedagógicos nos modos de fazer cinema e que cada professora desenvolve uma pedagogia própria a partir das escolhas feitas durante 0 processo de criação dos filmes de animação com seus alunos." Norton (2013) entende que a pedagogia audiovisual deve orientar-se pelas imagens que estão sendo produzidas na escola e pelas relações que são estabelecidas com essa produção. Levando em consideração os gestos criativos envolvidos nesse processo, é possível apontar elementos que poderiam (ou deveriam) constituir a pedagogia audiovisual, com base no que advogam as pesquisas em cinemaeducação e em mídia-educação.

Autores da mídia-educação ressaltam a importância da "alfabetização audiovisual" ${ }^{36}$ através da análise e produção de filmes, definida por Brasil (2014, p. 317) da seguinte maneira:

[...] chega um ponto em que entender um filme passa a ser relacioná-lo com outros filmes: perceber que é a mesma história daquele desenho animado que eu vi há tantos anos, mas agora com personagens adultos, contada de outro ponto de vista, e com final invertido. Ou relacioná-lo com um fato que saiu no jornal, com alguma coisa que aconteceu com alguém que eu conheço, ou mesmo comigo. Entender por que filmes são feitos, entender como se faz. Descobrir que filmes, novelas, comerciais, telejornais são feitos de um mesmo material básico: imagens em movimento acompanhadas de som. Saber que sempre tem alguém por trás, juntando esses pedaços para contar uma história. Compreender que eu também posso, de alguma maneira, juntar esses pedaços. Escolher em que história eu quero acreditar. É disso que se trata alfabetização audiovisual: transformar o ato de entender um filme num processo qualitativo.

Martín-Barbero (2014, p. 51) propõe uma pluralização dos alfabetos e das leituras para o que ele denomina de "alfabetização em comunicação". Ele inclui a leitura audiovisual como parte da "segunda alfabetização", a qual "nos abre as

36 Area (2012) considera que a alfabetização audiovisual está entre as "novas alfabetizações", ressaltando que: "Cada tipo de alfabetismo centra su atención en un modo de representación, de acceso y uso de la información codificada simbólicamente. Aunque cada una de estas propuestas tiene su razón de ser y justificación, todas ellas representan una forma parcial de la complejidad de la comunicación en nuestra cultura actual. La alfabetización debe ser un aprendizaje múltiple, global e integrado de las distintas formas y lenguajes de representación y de comunicacióntextuales, sonoras, icónicas, audiovisuales, hipertextuales, tridimensionales - mediante el uso de las diferentes tecnologías - impresas, digitales o audiovisuales en distintos contextos y situaciones de interacción social-." (p. 24). 
múltiplas escrituras que hoje conformam o mundo audiovisual e do texto eletrônico." A "primeira alfabetização [...] abre o mundo da escrita fonética." Para o autor, a primeira deve lançar as bases para a segunda, em um processo que não deve ser encarado como substituição de um modo de ler para outro, mas como um permanente diálogo que permita complexa articulação e recíproca inserção de uns e outros entre textos escritos (livros, blogs, sites, wikis), audiovisuais (filmes, vídeos de diversas naturezas) e hipertextos. Essa proposta de alfabetização em comunicação, como entende Martín-Barbero (2014, p. 51), deve levar em consideração "tudo o que isso implica de continuidades e rupturas entre os muito canônicos modos de ler livros e os muito anárquicos modos de navegar textos." O autor acredita que o futuro da civilização ocidental e o "sentido social da vida e o porvir da democracia" dependem de um mínimo de continuidade e diálogo entre esses modos de ler, indicando ser uma tarefa da educação a formação dos indivíduos para isso.

Sem tirar o foco dos aspectos até aqui destacados, Norton (2013) sintetiza e analisa a pedagogia audiovisual pelo olhar do cinema-educação, que tem como principal objetivo favorecer o contato dos alunos com diferentes opções estéticas, que vão além daquela formatada e reproduzida pela indústria cultural, possibilitando ao aluno se colocar dos dois lados da câmera:

Ensinar o audiovisual possibilita gerar uma maior reflexão sobre as diversas formas técnicas e estéticas como essa comunicação pode se dar, o que permite a ampliação do campo de conhecimento do aluno e o rompimento das barreiras de uma estética padronizada. Não se trata apenas de querer introduzir uma visão crítica em relação às produções televisivas e aos filmes comerciais, mas principalmente de abrir ao aluno outros caminhos diferentes dos que são oferecidos pela indústria cultural. (p. 17).

A autora lembra que Walter Benjamin, na década de 1930, defendia que "todos deveriam ter o direito de ser filmado", numa alusão à função transformadora do cinema ao estar em frente a uma câmera, permitindo assim, que todos pudessem ser atores de si mesmos. Nessa mesma direção, Kiarostami considera a participação de pessoas comuns dos povoados onde rodava seus filmes, dando-lhes a oportunidade de "existirem" de outra maneira. Ishaghpour (2008, p. 100) reflete sobre as escolhas do cineasta:

[...] para Kiarostami, parece que todo mundo só tem um desejo: ser fotografado, ver-se num filme, aparecer na tela. A tal ponto que seria necessário transformar a fórmula de Descartes num novo "tenho uma imagem, logo existo" que, neste contexto, não diz respeito apenas aos problemas da imagem espetacular e do narcisismo. [...] Ter a própria imagem talvez permita escapar ao fluxo ininterrupto, ao magma anônimo do qual fazemos parte, ser escolhido, distinguido, diferente da massa dos sem-nome desta terra. Assim como cada coisa, ao que se diz, espera 
que um poeta a nomeie para que, enfim, exista realmente, é possível que espere, ela também, a sua própria imagem. $E$, se todos desejam ser fotografados a fim de ter a prova visível, ao menos para si mesmos, de que existem, qual existência superior, qual prestígio não lhes caberá caso se tornem visíveis a todos, aparecendo na tela, no cinema.

Para Pires (2010), ver-se no vídeo pode ser algo interessante para todos nós. Diferente da visão que temos no espelho, em que há simultaneidade de gestos em uma imagem invertida, pode haver uma confusão sobre o sujeito ali refletido. Porém, quando a imagem de alguém, projetada no vídeo, está situada fora e diante de si. Essa imagem, como explica a autora, é de outro e, dessa forma, é possível relacionar-se com sua própria dimensão alteritária. Isso é relevante no processo de aprendizagem das pessoas, pois:

Em uma experiência com as câmeras, o olhar das pessoas se expande, buscando novas formas de interlocução e de revelação. Observa-se que a sensação de estranhamento é relatada por quase todas as pessoas que viram a própria imagem reproduzida na tela. A experiência da mediação da imagem técnica proporciona outra visibilidade ao sujeito em relação a si mesmo, desencadeando, paradoxalmente, o sentimento de estranhamento daquilo que the é familiar: a sua própria imagem. Ele percebe que há algo não reconhecível em relação a si próprio, podendo, posteriormente, incorporar essa nova imagem, assumindo-a como familiar. Nesse momento, vivencia-se uma experiência de transformação da consciência de si. (Pires, 2010, p. 290).

A autora compreende a construção da consciência de si como imprescindível para compartilhar seu olhar com o olhar do outro, criando uma linguagem que possibilita a comunicação nas relações socioculturais (Pires, 2010). Tal perspectiva remete ao conceito de alteridade, presente na hipótesecinema de Alain Bergala, assim definido no Abecedário de Cinema ${ }^{37}$ :

O cinema é, sem dúvida, a forma de arte que, imediatamente, capturou a alteridade. [...] Em um filme pode haver elementos que são completamente heterogêneos e diferentes. [...] Então, é evidentemente muito importante também pelo cinema, quando a criança ou o adulto pode fazer a experiência direta da alteridade. Em um filme, por exemplo, um homem pode se identificar completamente com uma mulher, com o pensamento ou os problemas de uma mulher, enquanto que na vida real é muito mais difícil. O cinema permite que nos coloquemos - é Serge Daney quem dizia isso - [...] no interior do outro, o que na vida real é extremamente difícil. É por isso que o cinema é extremamente importante para as crianças. Porque as crianças vivem em um mundo pequeno (a casa, a família e a escola) e o cinema lhes dá acesso a experiências que elas não conhecem. [...] Isso significa que o cinema permite ter uma ideia muito mais ampla da alteridade do que do seu próprio lugar na vida, que é pequeno, enfim, no nível da experiência. [...] O cinema nos fala de nós, de coisas que nós não conhecemos ainda, mas que sabemos que são para nós e sabemos que são nossas. Há filmes que as crianças veem e compreendem, ainda que no momento sejam muito pequenas, elas compreendem que isso tem a ver com elas. Logo, é por isso que o cinema é extremamente formador, mas muito profundamente sobre a relação com o mundo que se pode ter.

${ }^{37}$ Filme realizado pelo Lecav/Cinead, disponível em: http://www.cinead.org/videos. Acesso em: 8 jan. 2019. 
Seja para conhecer a si próprio, para educar para as mídias, para a formação política e cultural, ou para projetar-se nas imagens e histórias criadas coletivamente, é importante entender o cinema/audiovisual como uma arte/mídia relevante para a formação de jovens e crianças, tendo em vista o contexto social em que vivemos (Fantin, 2014; Fresquet, 2013; Pires, 2010). Mais do que compreender o que um cineasta busca dizer com sua obra, qual ideia ele persegue em seus filmes, aprender como as narrativas audiovisuais são construídas altera o modo de compreensão dos filmes a que temos acesso e nos conduz a outra interpretação sobre nós mesmos, sobre as narrativas que nos são direcionadas e sobre nossa realidade. A alfabetização audiovisual nos permite, por exemplo, compreender que imagens de câmeras de vigilância não são filmes, apenas registros, e que para serem filmes precisariam ser editadas, construindo uma narrativa.

A visão da perspectiva do cinema-educação percebe inicialmente o cinema para ver, com uma experimentação a partir do estranhamento, formação de gosto, alteração de expectativas, numa relação bem próxima à proposta pela experiência com as artes, para chegar, através do fazer cinematográfico, à "invenção de mundos", conforme entende Migliorin (2015, p. 45). Para o autor, fazer filmes na escola possibilita uma "experiência intensificada de fruição estético/política". Ao pensar o cinema na escola como uma experiência e não como uma mera transmissão de imagens, essa pedagogia audiovisual busca a circulação da arte através do envolvimento de professores e alunos com ela através dos filmes e de sua criação, "na expectativa de que encontros formais, estéticos e discursivos possam funcionar como aberturas para que sujeitos se engajem em mundos desconhecidos, recolocando em marcha processos subjetivos" (Migliorin, 2015, p. 52). Tais processos são responsáveis, conforme o autor, pela "invenção do eu e da comunidade", fazendo com que os resultados dessa vivência extrapolem os muros da escola e alcancem a formação cidadã dos envolvidos.

$\mathrm{Na}$ esteira da experiência sensível com as imagens, a perspectiva da mídia-educação considera que o audiovisual na escola abrange diversas competências e, por sua capacidade afetiva, não trabalha simplesmente a racionalidade, pois mobiliza também a sensibilidade. Conforme compreende Toledo (2014, p. 150): "Contribuímos, dentro da escola, não apenas para que este ou aquele aluno torne-se poeta, artista ou cineasta, mas para que ele consiga lidar com certas questões de desenvolvimento pessoal e com as quais 
tem problemas em lidar." Essa dimensão afetiva da pedagogia audiovisual se estende às relações que suas atividades propiciam entre professores e alunos, e entre os próprios alunos.

Ao defender o audiovisual na escola, em detrimento de outras linguagens, Merlo (2014) destaca o caráter coletivo da produção audiovisual, e como os envolvidos percebem a importância do trabalho em grupo e das conexões que são capazes de estabelecer em prol de um objetivo em comum. Por ser um ato de produção coletiva, tal atividade: "nos conduz a uma importante e necessária tarefa educativa e humana: aprender a construir relações entre os pares em que a escuta, o posicionamento e a tomada de decisões sejam partilhadas e assumidas." (p. 295). Dessa forma, tal perspectiva se embasa na contribuição da escola para a formação humana, na qual a comunicação mediada pelas tecnologias assume caráter estrutural (Fantin, 2014).

Teoricamente, os estudos de cinema-educação consideram que a pedagogia audiovisual é construída ou pode estar alicerçada em outras pedagogias, como a pedagogia do cinema, a pedagogia dos cineastas e a pedagogia da criação. A pedagogia do cinema trata dessa arte como fundada no aprendizado sobre sua linguagem. Como toda pedagogia subentende a existência de pelo menos um pedagogo e um aprendiz, nesse caso, o aprendiz seria o espectador. Nos primeiros filmes montados, o público necessitava de explicadores que informavam, por exemplo, que o close no rosto de uma mulher indicava que ela estava olhando para o anel, mostrado, em seguida, em plano detalhe. A pedagogia do cinema pode ser encontrada em sua maneira de contar as histórias por meio da montagem, por exemplo:

No exemplo citado por Eisenstein de uma mulher chorando seguida de uma outra imagem com um caixão, a ideia da viuvez surge como uma nova ideia, um novo conceito a partir da união de duas representações. Aqui o diretor russo não atribui sentido apenas à junção dos planos, mas põe acento na noção de "caminho" a ser percorrido e compreendido pelo espectador. (Migliorin \& Barroso, 2016, p. 17).

Para Duarte e Tavares (2010, p. 51), o caráter pedagógico do cinema como arte, em geral, tem uma pedagogia "relacionada às escolhas técnicas e estéticas a partir das quais as obras cinematográficas são construídas." A pedagogia do cinema se desenvolve também para defender o cinema como uma arte com linguagem própria e não como uma montagem de outras expressões artísticas (teatro, dança, desenho, pintura, entre outras), como foi considerada 
em seus primórdios, por George Méliès. Migliorin e Barroso (2016, p. 21) consideram estar na montagem das imagens o caráter pedagógico do cinema:

O cinema, assim como a educação, funciona devolvendo algo do sujeito ao mundo, inventado um receptor para essa devolução. Uma devolução que não é da coisa em si, mas da coisa atravessada por uma mediação estético-política. É nessa mediação que a montagem torna-se uma pedagogia.

A pedagogia dos cineastas é uma expressão cunhada inicialmente por Serge Daney, na década de 1970, e analisa gestos próprios de cada cineasta na feitura de seus filmes. Com base nesse pressuposto, Leandro (2001) e Fresquet (2011) analisam a pedagogia godardiana, cujos filmes são considerados verdadeiros cursos de política ou de como fazer cinema. Assim, a maneira de fazer, os personagens escolhidos, a história contada, a forma de montar os planos dão corpo à pedagogia de cada cineasta ${ }^{38}$, que ensina através de seus filmes ${ }^{39}$.

A pedagogia da criação, proposta por Bergala (2008), entende o cinema como arte e esta, por sua vez, como "um elemento perturbador" dentro da escola. Por isso, o cinema na escola não é algo a ser ensinado, mas experimentado: "a arte não se ensina, mas se encontra, se experimenta, se transmite por outras vias além do discurso do saber, e às vezes mesmo sem qualquer discurso. O ensino se ocupa da regra, a arte deve ocupar um lugar de exceção." (p. 31). Dessa forma, conforme compreende o autor, o cinema deveria ser pensado não como objeto, como um produto, mas como a "marca de um gesto de criação" (p. 34).

Partindo da premissa de que muitas crianças só têm contato com o cinema como arte através da escola, Bergala (2008) propõe que a pedagogia para ver e fazer filmes no espaço escolar estimule crianças e jovens a "filmar simplesmente" (Fresquet, 2013, p. 94), pousando o olhar e a escuta sobre o mundo que os rodeia e as pessoas com quem convivem, parando para observar, com a ajuda da câmera, as imagens que o cercam. Dessa forma, a pedagogia da criação busca que alunos e professores aprendam juntos a tornarem-se espectadores que vivenciam as emoções da própria criação (Bergala, 2008, p.

\footnotetext{
38 Entre os cineastas cujas pedagogias estão sendo analisadas pelos estudiosos brasileiros de cinema e educação aqui citados, além de Godard, podemos citar: Kiarostami, Glauber Rocha, Rosselini, Eisenstein e Vertov.

${ }^{39}$ De acordo com Leandro (2001, p. 35): "A pedagogia godardiana consiste desde então [final dos anos 60] em substituir o cinema pela escola, a fruição passiva do espectador pelo trabalho ativo do aluno."
} 
35). A partir da análise de planos, pontos de vistas e de exercícios de produção de imagens, os envolvidos nessa experiência podem experimentar outros jeitos de olhar e, consequentemente, contar, tornando algo do dia a dia diferente e interessante. Essa perspectiva guia-se pela premissa de "aprender cinema vendo e fazendo", como entende Fresquet (2013, p. 26), pois:

A relação com o mundo atravessada pela câmera produz uma determinada vivência para o aprendente/espectador criador, que é fortemente transformadora. O tipo de vivência do cinema na educação revela uma potência da imagem cinematográfica, que supera a visão tradicional linguística, semiótica e semiológica, propiciando, no espaço educativo, uma experiência sensível e direta com as obras de arte.

A pedagogia da criação parte da "análise de criação", ao propor ver filmes e analisá-los para, em seguida, passar ao ato de filmar. A proposta dessa análise é pensar o filme, voltando ao momento em que as decisões foram tomadas para que aquele resultado fosse apresentado:

Trata-se de fazer um esforço de lógica e de imaginação para retroceder no processo de criação até o momento em que o cineasta tomou suas decisões, em que as escolhas ainda estavam abertas. É uma postura que exige treinamento quando se quer entrar no processo criativo para tentar compreender, não como a escolha realizada funciona no filme, mas como se apresentou em meio a muitos outros possíveis. (Bergala, 2008, p. 130).

Como ações de filmagens orientadas pela pedagogia da criação ${ }^{40}$, Bergala propõe a aproximação do objeto a ser filmado em um jogo de três operações mentais fundamentais: escolher, dispor e atacar. Fresquet (2013, p. 56) define essas ações:

\begin{abstract}
"Escolher" é tomar decisões entre as diversas possibilidades de seleção (atores, cenografias, cores, ritmos, planos, utilização dos sons, etc.). "Dispor" os elementos significa colocá-los em relação uns com os outros na filmagem, na montagem e na mixagem de sons com as imagens. [...] Finalmente, "atacar" refere-se a agir, atuar, determinar e posicionar o ângulo ou ponto de ataque sobre as coisas escolhidas $e$ dispostas para filmar e fazê-lo.
\end{abstract}

No vídeo "Abecedário de cinema" (Fresquet \& Nanchery, 2012), Alain Bergala explica que esses gestos de criação não acontecem separadamente. Ele entende que essas três atitudes (escolher, dispor e atacar) ocorrem em processos simultâneos nos diversos momentos de fabricação do filme - roteiro, filmagem, montagem e mixagem.

\footnotetext{
${ }^{40}$ Em relação a ver filmes, Bergala (2008) apresenta como proposta de uma pedagogia do cinema na escola o contato com filmes de diversos autores e origens pelas crianças desde a infância para o desenvolvimento do gosto. Ele sugere algumas ações que podem ajudar a tocar as crianças através dos filmes e não obrigá-las a aprender com eles, como: propiciar o encontro dos alunos com os filmes, ensiná-los a frequentar filmes e a tecer laços entre eles. Para isso, o autor considera como tarefas da escola: a organização de uma coleção de bons filmes e disponibilização desta aos alunos e professores, além de levar os alunos a salas de cinema.
} 
Com base na proposta de Bergala, pesquisadores de cinema-educação desenvolveram atividades para experimentar o cinema na escola com crianças. Essa (que podemos chamar de) "pedagogia audiovisual do cinema-educação" é composta por exercícios "propostos em uma relação concomitante aos assuntos que são abordados nas aulas e à exibição de trechos de filmes [...]" (Norton, 2013, p. 153) e inclui atividades como:

- criar cartas filmadas;

- explorar relações entre sons e imagens;

- encontrar objetos com uma luneta de papel;

- fotografar um objeto por diferentes ângulos;

- construir câmera escura e brinquedos ópticos;

- ocultar algo no início do filme e revelá-lo no final;

- pensar um filme em uma determinada quantidade de planos;

- filmar ou fotografar um mesmo objeto de ângulos diferentes;

- escolher o som de um plano e só em seguida criar a parte visual;

- filmar uma cena de um minuto com câmera fixa (Minuto Lumière);

- definir regras/limites para filmar: cor, sentimento, tipo de plano, tempo de filmagem;

- escolher um plano de um filme e escrever um texto, simulando um diálogo entre o diretor e o montador durante a edição.

Algumas obras sistematizam diferentes exercícios com base nessa pedagogia, entre as quais cito:

- "Oficina de cinema para crianças" - professora chilena Alicia Vega (2012);

- "Princípios e propostas para uma introdução ao cinema com professores e estudantes: a experiência do Cinead/UFRJ" - Fresquet (2014);

- "Cinema: uma janela mágica" - Cineduc (Bullara \& Monteiro, 2015);

- "Cadernos do Inventar: cinema, educação e direitos humanos" Projeto Inventar com a Diferença (Migliorin et al., 2016).

- "Currículo de cinema para escolas de educação básica" (Fresquet, s/d).

Vale citar um programa que segue essa pedagogia: Cinéma, cent ans de jeunesse/Cinema, cem anos de juventude (CCAJ) ${ }^{41}$, desenvolvido pela Cinemateca Francesa. Trata-se de um programa internacional de educação em

\footnotetext{
41 Disponível em: http://www.cinematheque.fr/cinema100ansdejeunesse/. Acesso em: 10 jan. 2019.
} 
cinema que promove atividades em espaços educativos (escolas, ONGs, etc.) de diversas regiões da França e outros países, como Japão, Alemanha, Bélgica, Bulgária, Portugal, Espanha, Finlândia, Argentina, México, entre outros, incluindo o Brasil, com projetos atualmente no Rio de Janeiro e em São Paulo. Os projetos vinculados ao CCAJ seguem a proposta de Alain Bergala, sendo ele, inclusive, conselheiro artístico do programa.

As oficinas propõem uma metodologia em que filmes, cenas ou planos que são vistos pelos participantes funcionem como disparadores para a criação de suas próprias imagens que, por sua vez, serão, em seguida, vistas e comentadas. Essa experiência é mediada por um passeur, um professor e/ou um cineasta que, junto com os alunos, vivenciará as atividades propostas ${ }^{42}$.

\section{* Interseções entre as vertentes}

A pedagogia (audiovisual) do cinema-educação ${ }^{43}$ considera o professor como um mediador da experiência do cinema e os alunos. Além disso, de acordo com Bergala (2008), essa proposta não estabelece que o professor tenha uma formação específica em arte ou cinema, mas que seu gosto por filmes seja genuíno. A pedagogia da criação, por exemplo, busca a horizontalidade nas relações entre professor e alunos:

No caso do cinema na escola, é pela experiência que o professor pode sair do lugar daquele que ensina para experimentar com os alunos - um deslocamento que se faz essencial para uma dinâmica mais horizontal da produção de conhecimento. Até mesmo o gesto de ver um filme, com todos - professores e alunos - virados para o mesmo lado, já traduz a horizontalidade da experiência do cinema. (Migliorin, 2015, p. 51).

Esse talvez seja um ponto de interseção interessante das propostas de pedagogia audiovisual nas duas vertentes aqui analisadas, pois autores da mídia-educação (Fantin, 2014; Toledo, 2014) também consideram relevante essa horizontalidade das relações promovidas pelo cinema/audiovisual na escola:

\footnotetext{
42 Bergala (2008, p. 57) entende o passeur (passador, em português) como: "Alguém que dá muito de si, que acompanha, num barco ou na montanha, aqueles que ele deve conduzir e 'fazer passar', correndo os mesmos riscos que as pessoas pelas quais se torna provisoriamente responsável." Essa proposta tem sido comparada por autores do cinema-educação (Fresquet, 2013; Migliorin, 2014) às reflexões de Rancière (2013, p. 34) sobre a pedagogia do mestre ignorante, que questiona: "Como poderá o mestre sábio aceitar que é capaz de ensinar tão bem aquilo que ignora quanto o sabe?" Essas abordagens conversam com o pensamento de Paulo Freire (1996).

${ }^{43}$ Embora Bergala (2008) distinga o uso das expressões cinema e audiovisual, peço licença para o uso dessa expressão, pois se faz necessário inserir o termo audiovisual, uma vez que é sobre essa pedagogia que estou tratando aqui.
} 
A ideia parte de transformar o aluno em parceiro do professor na inclusão do audiovisual no cotidiano escolar. $O$ professor traz a linguagem, o estudante a técnica. O professor não necessariamente precisa conhecer a técnica. Se quiser, há muitos caminhos para aprendê-la, é acessível. E certamente é mais fácil aprender a técnica do que aprender a lidar com o aspecto pessoal, as relações humanas em uma equipe de filmagem, e essa é outra característica que caracteriza os aprendizados dos jovens que se envolvem em tais processos. (Toledo, 2014, p. 148).

Sobre esse "não saber" ensinar com o cinema/audiovisual, encarados pelos professores que "se arriscam" na pedagogia audiovisual, trago duas respostas possíveis, das vertentes do cinema-educação e da mídia-educação, respectivamente:

Ensinar com o cinema passa, justamente, por um "não saber" das partes que se preparam para o acontecimento, ou seja, para a invenção intempestiva consigo e com o outro, com as imagens, mundos e conexões que o cinema nos permite, nos autoriza. (Migliorin, 2010, p. 133).

Nesse percurso, a dificuldade que aparece é quase sempre a mesma: "Os professores não são preparados e não têm formação específica para tal." Mas nem sempre isso é problema, pois com uma formação adequada eles podem aprender, assim como aprendem a respeito de muitas outras questões que fazem parte do processo ensino-aprendizagem. (Fantin, 2014, p. 47).

Em ambas as perspectivas aqui apresentadas há uma confiança no professor e nas suas competências, caso esteja disposto a conhecer o cinema pelos filmes e a produzi-los com seus alunos. Qualquer que seja a vertente teórico-metodológica que embase a prática docente, é relevante que haja apoio de seus pares, que a escola abrace sua proposta e que haja tempo para o desenvolvimento de atividades realmente instigantes e modificadoras para que, assim, o cinema/audiovisual possa, por fim, ensinar algo ou ser propiciadora de uma experiência relevante para todos os envolvidos.

O importante é que o professor que queira aprender possa fazer a experiência, e uma das condições para tal, é que ele não esteja sozinho, que possa trocar e ir construindo suas competências com as ferramentas necessárias, e, nesse caso, a troca de experiências atua como um dispositivo. (Fantin, 2014, p. 47).

Grande parte dos estudos acerca das produções audiovisuais na escola (Husbye, 2013; Miranda, 2015; Pimentel, 2013) menciona que, desde o início do processo, as escolhas são tomadas em grupo e a ideia inicial do filme é de um, mas em pouco tempo passa a ser de todos; a divisão de tarefas, a escolha dos alunos que irão "atuar", a escrita do roteiro, o ensaio e as gravações são processos eminentemente coletivos, mobilizando fortemente gestos de sociabilidade entre os envolvidos: 
[...] o filme é coletivo: o tempo inteiro decisões são tomadas, críticas acontecem e conflitos se estabelecem. A mediação dos embates que emergem promove um enorme amadurecimento dos envolvidos. Do ponto de vista das inteligências pessoais, portanto, uma oficina é uma experiência extremamente rica. (Toledo, 2014, p. 151).

O que chamo de "pedagogia audiovisual da mídia-educação" está bem próxima, inclusive, da metodologia adotada pelo British Film Institute, junto às escolas, no Reino Unido, que leva em conta uma abordagem da construção do filme a partir do modelo de produção adotado pela indústria audiovisual. As atividades propostas para a criação de filmes na escola frequentemente seguem um conjunto de passos mais ou menos pré-definidos, sintetizados por Fantin (2014) como:

1) contextualização dos pressupostos e objetivos da mídia-educação;

2) escrita do roteiro e definição do tema a ser filmado;

3) escolha do gênero narrativo e estudo da linguagem audiovisual;

4) estudo e preparo sobre o conteúdo a ser tratado;

5) pré-produção com planejamento da gravação;

6) filmagem propriamente dita;

7) pós-produção com edição e acabamento do vídeo;

8) exibição e avaliação do produto final com os autores e a comunidade.

A fim de sintetizar objetivos e características das pedagogias audiovisuais aqui descritas, elaborei uma imagem que não tem por proposta comparar, mas propor um diálogo entre essas pedagogias. Por isso, escolhi como fundo um espiral de cores que se misturam. Cada tópico indicado ao lado da respectiva vertente "corresponde", no meu entender, ao tópico oposto da outra. A imagem não traz todas as possibilidades de diálogo apresentadas até aqui e, certamente, exclui outras que não abordei, mas pode funcionar como uma síntese das pedagogias audiovisuais: 


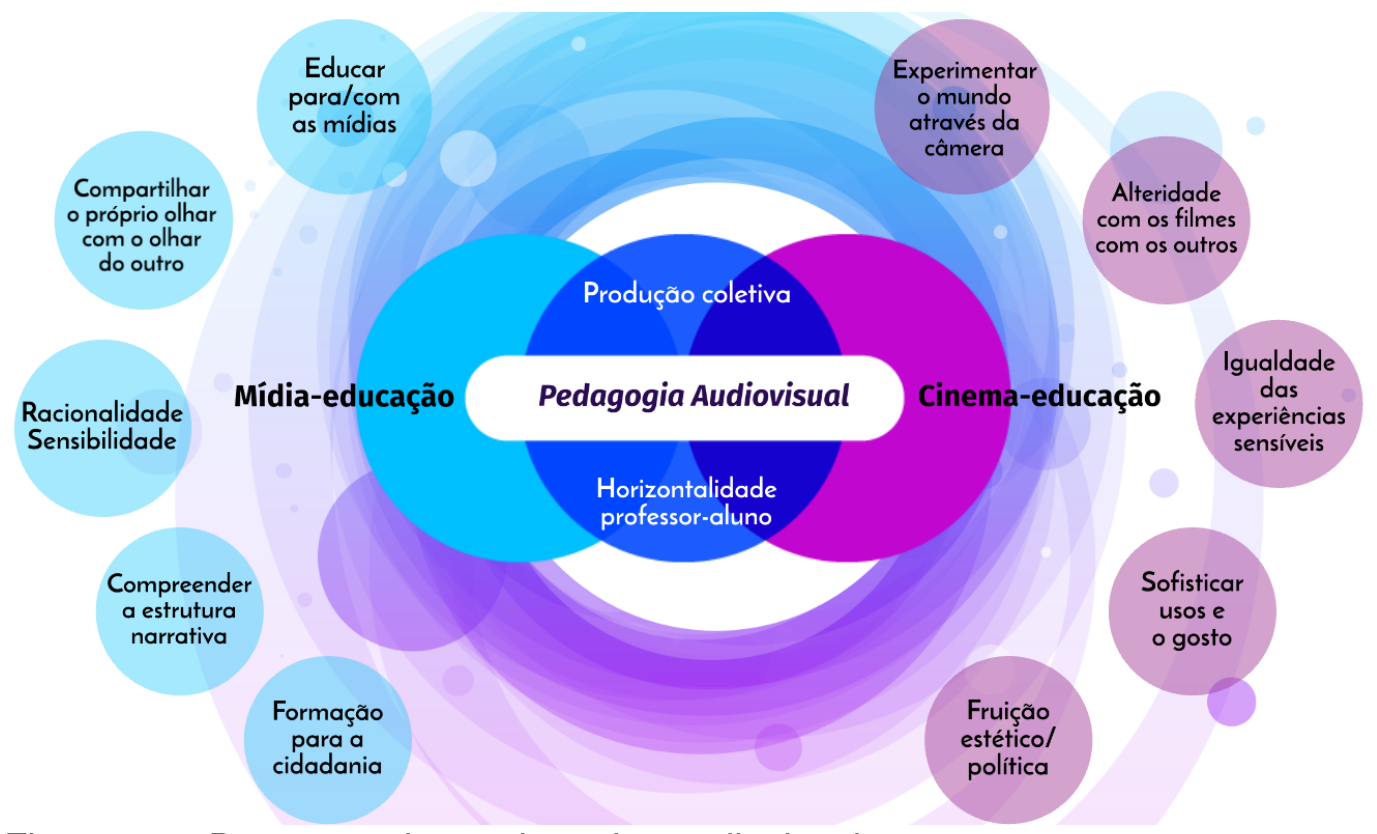

Figura 16 - Propostas das pedagogias audiovisuais Fonte: Elaboração própria.

Destaco como interseção das propostas o trabalho coletivo que, na vertente do cinema-educação parte do individual para o coletivo (Bergala, 2008), sendo essa premissa válida tanto para o professor que se pretende iniciador de seus alunos no cinema, como para os alunos que se "arriscarão" junto com ele nessa experiência. Esta interseção puxa a seguinte, da horizontalidade na relação professor-aluno, aqui já analisada.

Há, sem dúvida, outras pedagogias audiovisuais, com outras influências e vertentes, que não foram abordadas neste capítulo, pois a prática é sempre mais dinâmica e ágil que sua sistematização em teorias, assim como novas teorias influenciam novas práticas. Professores e pesquisadores estão cada vez mais se debruçando sobre atividades que motivem crianças e jovens, buscando tornar a escola mais atrativa para eles, e as tecnologias mediadoras da comunicação frequentemente estão entre essas atividades.

A discussão sobre as pedagogias especificamente voltadas à produção de filmes na escola algumas vezes aparece desvinculada de teorias que reflitam especificamente sobre esse tema, como já ressaltei anteriormente. Analisar as bases em que se estabelecem os objetivos dos projetos de produção audiovisual na escola pode nos auxiliar a caminhar com mais segurança nesse campo, usando metodologias e teorias que nos ajudem a responder perguntas ainda abertas sobre a contribuição do cinema/audiovisual para a educação. 


\section{2 \\ Habilidades sociocognitivas}

Partimos do princípio de que toda ação pedagógica, empreendida no espaço escolar, deve visar o desenvolvimento de competências e/ou habilidades necessárias às aprendizagens que ali ocorrem, razão pela qual precisam ter objetivos e procedimentos bem definidos. E isso certamente se aplica ao ensino/aprendizagem da produção audiovisual que, segundo alguns estudos (Fantin, 2014; Labrunie, 2017; Menezes, Adrão \& Rios, 2017; Toledo, 2014) contribuiria para o desenvolvimento de habilidades sociocognitivas, tais como capacidade de planejamento, organização de tarefas, tomada de decisões, atuação em equipe, antecipação de resultados, entre outras.

Conforme apresentei na revisão de literatura desta tese, o cinema na escola ainda figura, na maioria dos projetos, de maneira instrumental, ou seja, como um suporte para ajudar na aprendizagem de determinado conteúdo, ou como uma mídia (esta nomenclatura consegue chamar ainda mais atenção de crianças e jovens que buscam por formas de aprender mais significativas). Fazer/ver um filme na escola também vem atender aos professores que se mostram interessados em renovar suas práticas ou buscar estímulos para ensinar (Costa Oliveira, 2011). Assim chegamos aos novos modos de ensinar e aprender, tão presentes nas discussões sobre mídias na escola.

Com base em Mellouki \& Gauthier (2004, p. 538), entendo a escola como uma instituição que tem as culturas como matéria-prima. Esta define os utensílios, como conhecimentos e linguagens, por exemplo, e também os modelos de atuação social: como é ser um bom cidadão, um cientista ético, um professor implicado com seu ofício, além de exemplos ruins, obviamente. Dessa forma, a cultura permite - assim como advogam Bergala (2008) e outros (Fresquet, 2013; Norton, 2013) sobre a importância do cinema na escola "definir, elaborar ou modificar a relação consigo mesmo, com os outros e com o mundo" (Mellouki \& Gauthier, 2004, p. 538), sendo tarefa dos professores, escolher e interpretar, crítica e contextualmente, os "referentes culturais em benefício da formação intelectual dos alunos" (p. 542).

A partir dessa relação, "a cultura fornece visões, ou mesmo versões, sempre construídas, que precisamos compreender, interpretar, adaptar, aceitar ou rejeitar." (Mellouki \& Gauthier, 2004, p. 538), e é nesse contexto que os professores (entendidos como intelectuais críticos e intérpretes/tradutores) 
atuam como mediadores entre a cultura e seus alunos, o que torna sua atuação imprescindível dentro do funcionamento social. Portanto, a escola pode favorecer a criação de uma comunidade, que deveria ter por objetivo, como sugerem os autores:

Aclimatar os jovens à obra cultural humana, conscientizá-los com relação às dimensões ocultas da cultura (preconceitos, estereótipos, identidades nacionais, tribais, religiosas, sexuais) e aos fenômenos de inclusão e de exclusão por elas desencadeados, suscitando o interesse deles pelo contexto histórico das produções culturais e ajudando-os a desenvolver seu senso crítico e sua responsabilidade como seres culturais [...]. (p. 561).

A "assunção da tecnicidade midiática como dimensão estratégica da cultura", como entende Martín-Barbero (2014, p. 44), demanda da escola e dos professores, por extensão, a inserção de "novas figuras e campos de experiência em que se processam os intercâmbios entre escrituras tipográficas, audiovisuais e digitais, entre identidades e fluxos, assim como entre movimentos cidadãos e comunidades virtuais." Essa nova relação com o mundo, exige da instituição escolar - que perdeu seu status de instância de socialização detentora do saber - promover, como entende Bauman (2009), uma "educação (contínua, ilimitada e) permanente" 44 aos cidadãos.

O sociólogo afirma que na sociedade de hoje estamos impregnados pela alegria de livrar-nos das coisas, portanto, eliminar e descartar seriam as "paixões do nosso mundo". Essa concepção, que inicialmente estaria voltada aos objetos, estende-se às relações entre as pessoas. Em um mundo cujos objetos e relações duram apenas enquanto são necessários, pois rapidamente são substituídos por outros, que finalidades e contornos têm a educação? De acordo com o autor, a escola precisa, então, reinventar seus modos de ensinar a partir dessas novas demandas, buscando elaborar conhecimentos prontos para utilização imediata e imediata eliminação:

Os praticantes de uma vida fatiada em episódios [como nas séries audiovisuais], cada um dos quais com um novo início e um fim brusco, não têm necessidade de uma educação que busque lhes fornecer os instrumentos idôneos para um mundo invariável (ou para um mundo que se move a uma velocidade inferior em relação àquela do conhecimento ao qual deveria estar ligada). (Bauman, 2009, p. 669, inserção minha).

Os estudantes, por sua vez, precisam desenvolver rápida capacidade de aprendizagem, pois as informações obtidas envelhecem rapidamente e são prontamente ignoradas, considerando o conhecimento adquirido como

\footnotetext{
44 Para diferenciar da "educação permanente", concebida pelas organizações empresariais, amplio o termo com duas palavras indicadas pelo próprio autor no decorrer do texto para sua concepção de educação permanente para "outorga dos poderes" aos cidadãos.
} 
eminentemente eliminável. Esse "novo conhecimento", de acordo com Bauman (2009), serve de combustível para produzir em larga escala a ignorância humana e suas formas de manutenção. O próprio autor apresenta a educação (contínua, ilimitada e) permanente para escapar dessa "nova" relação com o conhecimento. Bauman (2009) explica que a "educação permanente"45 surge no mundo do trabalho, com base na formação por competências para suprir as demandas sempre mutáveis, tendo por base a eficácia e a competitividade dos indivíduos. Esse tipo de educação promove o desenvolvimento de capacidades e habilidades focadas no indivíduo, deslocado de sua coletividade ${ }^{46}$.

Bauman (2009) reinscreve o conceito de educação permanente para pensar o lugar da educação dentro dessa nova ordem social, com base no documento Making a European área of life long learning a reality, publicado pela Comissão Europeia, em 2001. Ele toma a educação permanente para "outorga de poderes", sendo esta uma autorização conquistada pelos cidadãos quando:

[...] adquirem a capacidade de controlar, ou ao menos de influir sobre as forças individuais, políticas, econômicas e sociais que poderiam incidir no curso de suas vidas. Para dizer francamente, uma "autorização" autêntica requer não apenas a aquisição das capacidades que consentiriam em fazer parte do jogo criado por outros, mas também a aquisição de poderes tais que permitam influenciar os objetivos, os lugares e as regras do jogo. (Bauman, 2009, p. 679).

O autor deixa bastante claro que essas capacidades não são apenas individuais, mas também sociais. Para o renascimento da esfera pública - um desafio dessa educação contínua, ilimitada e permanente - Bauman (2009) considera a capacidade de interação com os outros (diálogo, negociação,

\footnotetext{
${ }^{45}$ Bauman (2009, p. 671) comenta o seguinte sobre a construção da expressão: "Desde que os antigos sábios gregos inventaram a noção de Paideia foi preciso mais de dois mil anos para transformar a ideia de 'educação permanente', de oxímoro (contradição dos termos) em pleonasmo (do tipo 'manteiga amanteigada', 'ferro metálico'...). Entretanto, a atestação dessa notável transformação ocorreu recentemente - nos últimos dez anos - sob o impacto da mudança acelerada do ambiente social no qual os protagonistas principais da educação (tanto professores como educandos) deviam agir."

${ }^{46}$ Aqui é preciso fazer uma breve consideração sobre a abordagem das competências e habilidades no sistema educacional brasileiro, que surgem no início do século XX, quando o Sistema de Avaliação da Educação Básica (Saeb) passou a utilizar a teoria de resposta ao item (TRI) e levar em conta a periodicidade em suas avaliações de larga escala. As competências e habilidades passaram a ser indicadas também nos Parâmetros Curriculares Nacionais e nas Diretrizes Curriculares Nacionais, que orientavam a organização curricular. As primeiras discussões sobre a Base Nacional Curricular Comum (BNCC) haviam deixado de lado a aprendizagem por competências, pautando-se nos conceitos de direito de aprendizagem, porém, na $3^{\text {a }}$ revisão, voltou a tratar de habilidades. O problema dessa abordagem por habilidades, é que a aprendizagem não acontece de forma linear e individualizada, se considerarmos que a cognição é distribuída e, portanto, um processo coletivo que pode ocorrer de formas heterogêneas de acordo com os indivíduos, os grupos, os contextos em que se inserem e as abordagens de ensino. Dessa forma, as habilidades/competências são tratadas como fim, para cumprir processos avaliativos que visam responder demandas externas e de mercado, e não como relevantes contributos dos processos de aprendizagem, deslocando sua importância para o resultado e não para a construção social.
} 
gestão, redução de conflitos) como a mais importante e necessária a ser desenvolvida pela escola.

Uma tarefa que, como a educação, deveria ser para o bem dos homens e mulheres líquido-modernos, capazes de procurar alcançar os próprios objetivos com ao menos um pouco de independência, segurança de si mesmos e esperança de sucesso. Mas há outro motivo que, apesar de menos discutido, é mais eficaz: trata-se de não adaptar as capacidades humanas ao ritmo desenfreado das mudanças do mundo, e sobretudo de tornar o mundo, em contínua e rápida mudança, mais hospitaleiro para a humanidade. Essa tarefa requer uma educação contínua e permanente. [...] Não é preciso atualizar só as capacidades técnicas, não é só a educação voltada para o trabalho que precisa ser permanente. $\mathrm{O}$ mesmo vale, com uma urgência ainda maior, para a educação para a cidadania. (Bauman, 2009, p. 680-681).

Segundo Ferrés (2007), as competências audiovisuais, como parte das competências midiáticas, devem ser levadas em consideração nos processos de ensino e aprendizagem, embora esta não seja uma realidade e ainda existam poucas tentativas para se definir uma pessoa competente em comunicação audiovisual. Tal fato pode estar relacionado à falta de sistematização do que vem sendo produzido pelas pesquisas sobre o tema, devido aos diversos âmbitos em que essas competências se inserem (comunicação, educação, psicologia, sociologia), com propostas, indicadores e terminologias distintas (Amor Pérez \& Delgado, 2012). As competências audiovisuais que observamos foram desenvolvidas em uma oficina de vídeo, a partir de um processo coletivo. Pereira et al. (2018) analisam a produção midiática individual e coletiva de jovens em diferentes contextos e destacam que é preciso considerar a diferença entre as habilidades desenvolvidas em atividades coletivas:

A principal diferença está nas habilidades que eles desenvolvem ao longo do processo. Quando realizam produções em grupo, adquirem outras habilidades associadas à gestão social, como a capacidade de coordenar ou liderar, por exemplo. Deve-se notar que, na maioria dos casos, as produções coletivas são feitas dentro do grupo de pares. ${ }^{47}$ (Pereira et al., 2018, p. 106).

É possível considerar, então, que a oficina de vídeo propicia o desenvolvimento de habilidades e aprendizagens a partir das interações dos envolvidos, sendo, portanto, um momento de interação social em que ocorre o desenvolvimento sociocognitivo dos estudantes.

\footnotetext{
47 Tradução minha do original: "The main difference is in the skills they develop through the process. When they carry out group productions, they acquire other skills associated with social management, such as the ability to coordinate or lead, for example. It should be noted that in most cases collective productions are made within the peer group."
} 


\section{* Interação/cognição social e sua relevância para aprendizagem escolar}

Para chegarmos à natureza social da cognição é importante destacarmos do que trata esse conceito, abordado por diversas teorias, de diferentes áreas, inclusive a educação e, mais especificamente, a educação para as mídias. Dentro desse enorme campo em que a cognição se insere, Mondada (2002) destaca duas grandes tendências que emergiram sobre tal conceito. A primeira delas considera que o indivíduo possui capacidades ancoradas em seu espírito ou em seu cérebro, a partir das quais ele é capaz de raciocinar e perceber o mundo; a outra toma a cognição como um conjunto de práticas sociais publicamente mobilizadas em ações e contextos para os/pelos participantes. Esta última concepção se difere da primeira, ao entender que a cognição não reside unicamente nos indivíduos, mas sobretudo nos coletivos, distribuída nos artefatos, estando fortemente personificada em suas condutas corporais. Essa segunda vertente é conhecida como cognição situada e distribuída ${ }^{48}$.

"Cognição social", por sua vez, é um conceito em disputa, usado pela linguística cognitiva e, de acordo com Leite (2003, p. 220), pode ser definido a partir de duas teorias-padrão: a primeira trata-a como um processo mental de concepções sobre o mundo, em que o "social" faz referência apenas aos "objetos da cognição e a preocupação com os mecanismos psicológicos usados pelos sujeitos para perceberem a si mesmos e aos outros." Conhecida como concepção mentalista da cognição social, essa teoria se utiliza de pesquisas de laboratório e questionários que analisam respostas verbais dos sujeitos relacionadas a processos mentais internos. A outra teoria "se ocupa da natureza social dos sujeitos da percepção e da construção do nosso conhecimento sobre o mundo." (Leite, 2003, p. 220). Portanto, o foco dessa proposta recai sobre como se dá a percepção e descrição do mundo social pelos sujeitos de um determinado grupo de pessoas, com uma cultura particular, no curso da interação. Ainda de acordo com Leite (2003, p. 221), há um enfoque alternativo sobre a cognição social que:

[...] se alinha com o estudo do que ocorre externamente ao indivíduo e se recusa a reconhecer uma cisão entre processos internos e externos. A cognição social, nesta perspectiva, é distribuída entre as pessoas, e seu estudo não se interessa pelo processamento individual como tal. Assim, se torna parte do domínio público e é ligada às ações nas quais as pessoas atuam em conjunto.

48 De acordo com Mondada (2002), esse conceito teve grande influência da etnometodologia e da análise conversacional. 
A cognição social, dessa forma, parte da interação social, definida por Moreno e Ison (2013) como a relação entre duas ou mais pessoas por um período prolongado de tempo. Tal conceito passou a ser foco de estudos mais recentes ligados à educação, a partir da maior visibilidade das interações sociais entre alunos, mais especificamente ao tratarem sobre bullying. A escola é um forte ambiente de interação social, a qual ocorre, na maioria das vezes, em atividades coletivas, nas quais se aceitam um ou mais líderes em uma cadeia hierárquica envolvendo a comunidade educativa. Nessa interação, algumas habilidades, definidas pelo campo de estudos como "sociocognitivas", são utilizadas para resolver diversos tipos de situações, favorecendo as soluções adequadas em conflitos interpessoais que podem influenciar negativamente no desempenho social dos alunos (Moreno \& Ison, 2013). De acordo com essas autoras, o comportamento social é constituído por aspectos positivos e adaptativos (competência social e habilidades sociais) e negativos (comportamentos disruptivos externalizantes: agressões, brigas etc.; e problemas internalizantes: ansiedade, isolamento etc.). O melhor desempenho de estudantes na codificação de sinais sociais se vincula a níveis mais elevados de competência social. Portanto:

\begin{abstract}
A maior ou menor eficácia na utilização de recursos cognitivos, afetivos e de conduta que uma criança emprega para resolver situações cotidianas de intervenção social dependerá da percepção de suas próprias habilidades para gerar alternativas de solução frente a um problema, para regular suas emoções, para pensar nas consequências de cada ação e, finalmente, para tomar a melhor decisão. ${ }^{49}$ (Moreno \& Ison, 2013, p. 67).
\end{abstract}

Enquanto algumas correntes atuais da psicologia embasam seus estudos sobre a cognição social para tratar do relacionamento dos indivíduos entre si, com o meio e com a cultura, conforme apresentado até aqui, autores como Cole \& Engeström (1998) - com base nos estudos de Luria, Leontiev e Vigotski, no âmbito da teoria sócio-histórico-cultural (TSHC) da cognição - compreendem a cognição como parte fundante da teoria cultural da mente e, portanto, adotam o pressuposto de que a cognição é social. Assim, assumem a tese de que os processos cognitivos não são individuais e não ocorrem somente no interior dos indivíduos, mas, ao contrário, são distribuídos entre indivíduo, pessoas e artefatos culturais. Apresento brevemente os pressupostos que fundamentam

49 Tradução minha do original: "La mayor o menor eficacia en la utilización de los recursos cognitivos, afectivos y conductuales que un niño emplee para resolver situaciones cotidianas de interacción social, dependerá de la percepción de sus propias habilidades para generar alternaticas de solución frente a un problema, para regular sus emociones, para pensar en las consecuencias de cada acción y, finalmente, para adoptar la mejor decisión." 
essa perspectiva teórica no intuito de discutir como as interações promovidas nas atividades de produção audiovisual podem contribuir para o desenvolvimento de habilidades sociocognitivas na escola.

A TSHC considera a interação social como: "a condição permanente de existência do sujeito, a qual se concretiza numa constante relação com os outros." (Pino, 1993, p. 57). Essa definição está baseada na natureza social do homem, entendido como resultado da sua atividade (denominada "trabalho" por alguns autores, como o próprio Pino) através da qual ele transforma simultaneamente o mundo/a natureza (para atender suas necessidades) e a si próprio. De acordo com Pino (1993), nessa atividade o homem desenvolve as funções mentais e habilidades técnicas, pois durante esse processo ele se apropria de instrumentos (materiais ou simbólicos) que permitem operações não incorporadas nele. Freitas (1994, p. 90) explica que:

Para Vygotsky, a possibilidade de transformar o mundo material, mediante o emprego de ferramentas, estabelecia as condições para a modificação da própria atividade reflexa sua transformação qualitativa em consequência. Este processo, porém, se completava mediado pela construção de uma classe especial de ferramentas: aquelas que permitissem realizar transformações nos outros, ou no mundo material através dos outros. Ele chamou essas ferramentas de signos e considerava que eram proporcionados essencialmente pela cultura, pelas pessoas do meio, enfim, pelos outros.

A atividade/trabalho produzida/o pelo homem resulta em objetos culturais (instrumentos ou ferramentas) e na modificação sociocultural do próprio homem, uma vez que o produto da invenção humana é considerado uma "ideia materializada que faz dele um objeto de conhecimento e que pode evocar nos outros um sentimento estético." (Pino, 1993, p. 52). O instrumento se constitui objeto cultural porque fala do seu autor e também fala ao outro. As produções humanas são, portanto, meios de transformar o mundo e o próprio homem.

A TSHC compreende que o homem se diferencia dos demais animais justamente pelo fato de conseguir inventar e empregar ferramentas que modificam sua condição de existência, ao mesmo tempo em que operam sobre o homem, modificando-o e desenvolvendo também sua condição psíquica (Cole \& Engeström, 1998). Portanto, a natureza do homem passa de biológica para social (Pino, 1993), o que equivale a dizer que somos "biologicamente" seres sociais. Isso oferece ao homem um mundo duplicado, uma vez que ele parte de um mundo dado diretamente (natural) para outro dado culturalmente (social) na linguagem. Esta, por sua vez, não funciona apenas como um meio de 
comunicação, pois é responsável pelas relações simbólicas necessárias para a compreensão do mundo e também da história que o antecede, por exemplo.

Para Cole \& Engeström (1998), é a linguagem que permite ao homem abordar "coisas" com as quais não teve contato direto ou que fizeram parte de gerações anteriores a ele. Quando alguém é convidado a experimentar o cinema através da criação do Minuto Lumière, ele, de certo modo, recria os movimentos e conceitos originários do próprio cinema, depois que the são explicitados (por meio da linguagem falada, das imagens e de outras ações) os modos de agir para chegar ao resultado esperado. Para lidar com as/os tecnologias/instrumentos criados pelas gerações anteriores e para agir sobre os instrumentos dados então aos aprendizes e, assim, criar objetos culturais, eles necessitam de um mediador, que compartilhe com eles os saberes e as operações mentais necessárias à execução daquelas atividades (este pode ser o professor, um técnico ou mesmo um colega mais experiente, considerado na TSHC como par mais capaz).

Vigotski acrescentou a essa teoria a lei geral do desenvolvimento cultural, ao entender que o homem faz parte de uma comunidade e que, ao relacionar-se com ela, segue regras, fazendo parte da divisão de trabalho, distribuição de tarefas e seguindo os poderes e responsabilidades nela instituídos (Cole \& Engeström, 1998).

Segundo esses autores, a antropologia, ao superar a concepção de que a cultura era uniforme, ofereceu contribuição relevante para que a psicologia formulasse a hipótese de que a cognição é socialmente distribuída. Cole \& Engeström (1998) explicam que Ted Schwartz (1978) foi preponderante ao conceber que a cultura era distribuída, devido à impossibilidade de duas pessoas compartilharem igualmente a totalidade da cultura do grupo a que pertencem. Essa concepção estava ancorada na maneira como a cognição se distribui entre as pessoas de um grupo, em virtude dos papéis sociais que elas desempenham, determinados filogenética e culturalmente. Dessa forma, conforme explicam os autores, parte do conhecimento cultural que alguém detém é equivalente aos conhecimentos e perspectivas cognitivas que os demais participantes de seu grupo podem compartilhar.

\section{* Cognição distribuída e oficinas de produção audiovisual na escola}

Para Cole \& Engeström (1998), a cognição distribuída ocorre dentro de um determinado contexto em que as ações cognitivas envolvidas nas tarefas/ações 
são distribuídas entre as pessoas envolvidas, os instrumentos/artefatos e as regras de conduta estabelecidas ou inconscientemente conhecidas pelo grupo. Analisando contextos em que ocorrem atividades de ensino/aprendizagem, à luz desses pressupostos, pode-se supor que práticas pedagógicas que favorecem as interações entre os aprendizes, a aprendizagem coletiva e a colaboração criam ambientes especialmente favoráveis aos processos cognitivos. É o caso, por exemplo, das práticas de produção audiovisual na escola, pois estas têm, por princípio, a exigência do trabalho coletivo e do compartilhamento de conhecimentos e habilidades. A figura a seguir ilustra essa ideia:

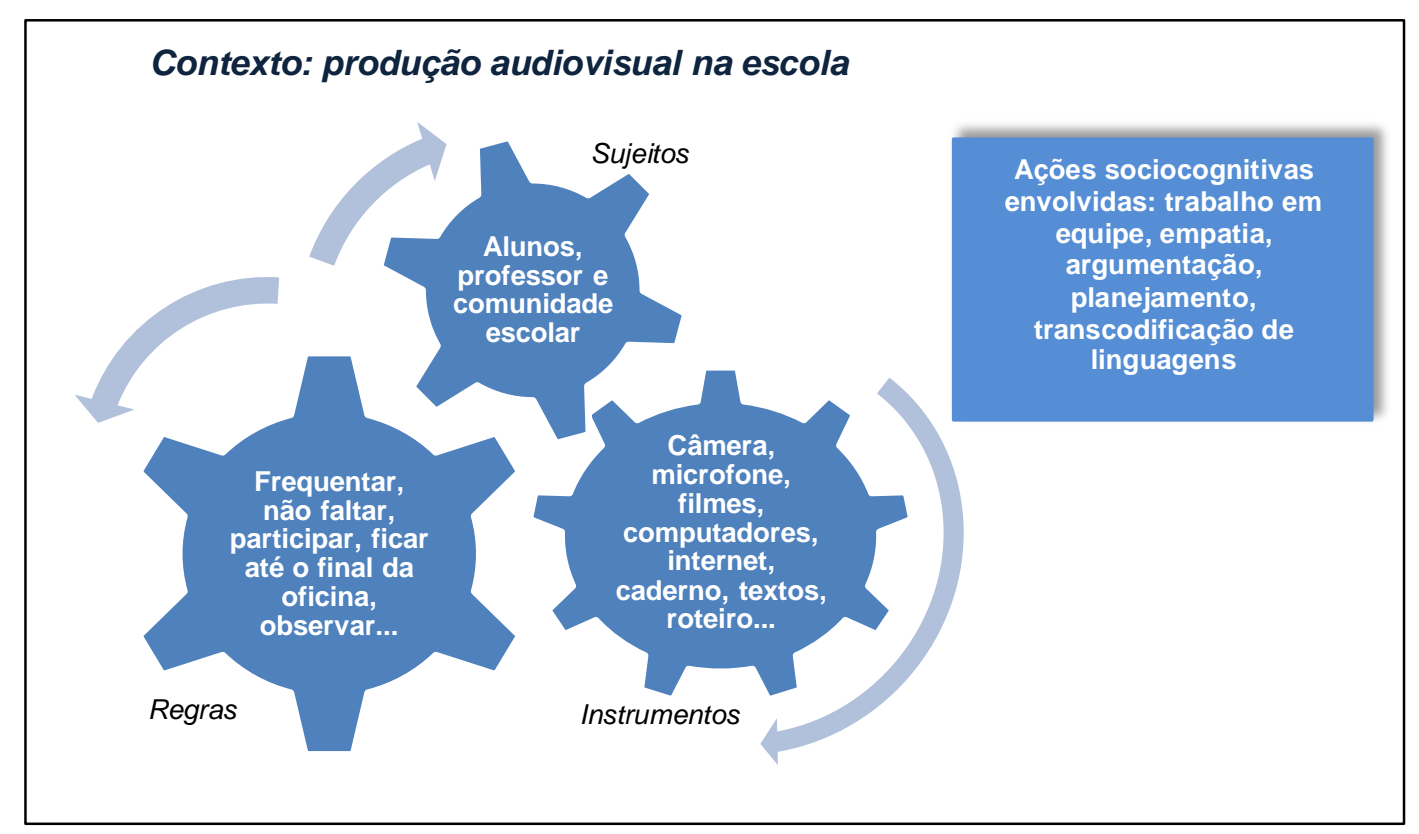

Figura 17 - Produção audiovisual na escola Fonte: Elaboração própria.

$\mathrm{Na}$ atualidade, muitos programas educativos têm se utilizado dos estudos que abordam a cognição social para resolver problemas de conflitos entre os alunos e auxiliar o processo de ensino-aprendizagem. Para os autores da TSHC, qualquer atividade pedagógica deve ter em vista que a cognição humana é distribuída em regras de determinado grupo, artefatos criados pelo homem e dados histórico-culturalmente produzidos, ou seja, de que todo o conhecimento é mediado culturalmente. Assim, cabe perguntar o quanto a pedagogia audiovisual leva em conta esses pressupostos em seus objetivos e se contribui, de forma relevante, para o desenvolvimento de habilidades específicas, ou seja, aquelas necessárias às ações e aprendizagens em equipe.

As oficinas promovidas em contextos educacionais são indicadas por pesquisas da área (Bentes, 2014; Fantin, 2014; Fresquet, 2013; Migliorin, 2014; 
Toledo, 2014) como um momento rico de interação entre os participantes, uma vez que se trata de uma atividade proposta para um grupo e, como todo grupo, é formado por sujeitos de personalidades diversas e com interesses e expectativas diferentes.

Além do aprendizado da linguagem audiovisual, grande parte das avaliações que professores e pesquisadores fazem de experiências de produção audiovisual na escola aponta para a melhoria de relacionamento interpessoal, mudança de postura e melhor relacionamento com a escola (Fantin, 2014; Labrunie, 2017; Toledo, 2014). As aprendizagens coletivas são acompanhadas pelo desenvolvimento individual de alguns alunos em relação à desinibição, à melhor desenvoltura em falar em público, envolvimento em trabalhos em grupo, postura de liderança, entre outros (Menezes, Adrão \& Rios, 2017; Orofino, 2005). Kearney \& Schuck (2005, p. 5) apresentam os seguintes resultados evidentes em casos de produção de vídeos digitais por alunos para aprendizagem de conteúdos escolares:

[...] desenvolvimento de habilidades de produção de filmes e desenvolvimento de linguagem relacionada, desenvolvimento de habilidades de alfabetização midiática, habilidades de comunicação e apresentação; habilidades metacognitivas e afetivas. Em sintonia com as crenças do professor, os alunos demonstraram níveis altamente impressionantes de comportamento autônomo, engajamento e motivação..$^{50}$

Labrunie (2017) descreve algumas das crenças dos professores, sujeitos de sua pesquisa, em relação às atividades com vídeo na escola. Do mesmo modo, o material produzido pelo coletivo Nossa Tela (2011), de São Paulo, traz impressões dos professores sobre seus projetos e os objetivos que os subsidiam. Os professores acreditam que o vídeo na escola pode auxiliar os alunos a:

- ter compromisso;

- vencer a timidez;

- ampliar a criatividade;

- aprender a cumprir prazos;

- ampliar repertório pessoal;

- promover a divisão de tarefas;

- estimular o trabalho em grupo;

50 Tradução minha do original: "[...] development of movie-making skills and related language development, development of media literacy skills, communication and presentation skills, metacognitive and affective skills. In tune with the teacher beliefs, students displayed highly impressive levels of autonomous behaviour, engagement and motivation." 
- aumentar o senso de coletividade;

- motivar alunos desinteressados pela escola;

- enxergar e valorizar os trabalhos uns dos outros;

- trabalhar determinados temas de forma mais interessante;

- apresentar trabalhos para os colegas de forma motivadora;

- tornar-se protagonista da construção dos seus conhecimentos;

- explicar de outra maneira a matéria, facilitando a aprendizagem;

- entrar em contato mais íntimo e de forma mais prazerosa com a matéria;

- vivenciar um aprendizado participativo e significativo para ampliar olhares.

Essas expectativas (e resultados esperados) vão ao encontro do que geralmente buscam os projetos que propõem atividades com audiovisual na escola. Algumas delas aprecem também na fala de professores, diretores, gestores públicos e agentes de projetos ao comentarem sobre os objetivos ou resultados do trabalho com filmes realizado com crianças e jovens.

\section{* Habilidades promovidas pela oficina de audiovisual na escola}

Entre os resultados esperados e obtidos com os processos de produção audiovisual na escola destaco: capacidade de trabalhar em grupo, de dividir tarefas e cumprir prazos; escuta do outro, argumentação em relação às próprias ideias e transcodificação de linguagens. Essas atitudes são mencionadas por muitos professores que ministram oficinas de audiovisual e também por aqueles que propõem atividades desse tipo aos alunos, nas diferentes disciplinam que ministram (Kearney \& Schuck, 2005; Labrunie, 2017), independente da pedagogia audiovisual que tenha sido adotada. Nesta tese, buscamos averiguar se efetivamente isso ocorre, ou seja, se oficinas de produção audiovisual realizadas em contexto escolar de fato contribuem para o desenvolvimento de habilidades necessárias à interação social, aqui denominadas como sociocognitivas, à luz da linguística cognitiva (Leite, 2003; Moreno \& Ison, 2013) e da TSHC (Pino, 1993; Cole \& Engeström, 1998), as quais destaco a seguir: 


\begin{tabular}{|c|c|}
\hline Habilidades & Atitudes \\
\hline $\begin{array}{l}\text { Trabalhar em } \\
\text { equipe e } \\
\text { realização de } \\
\text { tarefa conjunta }\end{array}$ & $\begin{array}{l}\text { Participar das atividades em grupo } \\
\text { Negociar opiniões dos participantes } \\
\text { Propor soluções para problemas futuros } \\
\text { Tomar parte das decisões } \\
\text { Manter os acordos } \\
\text { Demonstrar postura de liderança } \\
\text { Pedir opiniões dos colegas sobre alguma solução a tomar }\end{array}$ \\
\hline $\begin{array}{c}\text { Capacidade de } \\
\text { empatia }\end{array}$ & $\begin{array}{l}\text { Manter postura atenta em relação ao outro } \\
\text { Demonstrar que compreende o outro } \\
\text { Mediar um conflito entre os participantes }\end{array}$ \\
\hline $\begin{array}{l}\text { Capacidade de } \\
\text { planejamento de } \\
\text { atividades }\end{array}$ & $\begin{array}{l}\text { Organizar atividades atento aos prazos } \\
\text { Distribuir tarefas } \\
\text { Cumprir as tarefas no prazo }\end{array}$ \\
\hline $\begin{array}{l}\text { Capacidade de } \\
\text { organização de } \\
\text { tarefas em } \\
\text { diferentes } \\
\text { etapas }\end{array}$ & $\begin{array}{l}\text { Ordenar tarefas conforme sua importância para o trabalho final } \\
\text { Selecionar participantes conforme as habilidades de cada um para } \\
\text { a tarefa } \\
\text { Acompanhar atividades e seu cumprimento em suas diferentes } \\
\text { etapas } \\
\text { Mudar de planos em caso de não atendimento das tarefas } \\
\text { conforme planejado } \\
\text { Atribuir tarefas para todos } \\
\text { Expressar uma ideia com clareza para o outro } \\
\text { Defender uma proposta, utilizando argumentos que justifiquem seu } \\
\text { ponto de vista } \\
\text { Mudar o argumento em defesa de uma mesma ideia } \\
\text { Incorporar sugestões ao argumento original }\end{array}$ \\
\hline $\begin{array}{l}\text { Capacidade de } \\
\text { transcodificação } \\
\text { de linguagens }\end{array}$ & $\begin{array}{l}\text { Escrever uma cena a partir de um argumento } \\
\text { Indicar como encenar determinado texto escrito } \\
\text { Indicar como filmar o que será encenado } \\
\text { Indicar como editar o que foi filmado } \\
\text { Indicar como demonstrar passagem de tempo } \\
\text { Compreender a mudança de ordem entre o roteiro e o que está } \\
\text { sendo filmado } \\
\text { Indicar música/som e/ou iluminação para passar impressões } \\
\text { destacadas no roteiro }\end{array}$ \\
\hline
\end{tabular}

Quadro 6 - Habilidades sociocognitivas e atitudes envolvidas na produção audiovisual escolar

Fonte: Elaboração própria.

Uma oficina de produção audiovisual pressupõe trabalho em equipe, pois se trata de uma atividade eminentemente coletiva. Para Kearney \& Schuck (2005), antes de iniciar as atividades de gravação, os alunos precisam estar familiarizados e desenvolver as habilidades necessárias para o trabalho em equipe para se engajar nesses projetos de maneira eficaz e sem se distrair. Dependendo do modo como é proposto e executado, o trabalho em grupo pode favorecer o desenvolvimento das habilidades indicadas no quadro anterior, além de outras, tais como a construção de papéis sociais e a formação de lideranças.

Para assegurar a coesão do grupo, os alunos precisam aprender a negociar e a emitir e aceitar opiniões. Toledo (2014) destaca que os momentos 
em que isso ocorre são ricos para a compreensão, pelos participantes, de que o que está em jogo não é gostar ou não do outro, mas decidir sobre a melhor ideia, pois eles entendem que quando se critica a ideia do outro não é o colega que está sendo alvo da crítica, mas sim a ideia dele:

Quando os estudantes se desentendem, é fundamental pontuar que o que está em jogo não são eles, não é gostar um do outro, mas o não gostar daquilo que foi dito ou feito. [...] Um filme é coletivo: o tempo inteiro decisões são tomadas, críticas acontecem e conflitos se estabelecem. A mediação dos embates que emergem promove um enorme amadurecimento dos envolvidos. Do ponto de vista das inteligências interpessoais, portanto, a oficina é uma experiência extremamente rica. (Toledo, 2014, p. 151).

Se considerarmos que as oficinas nas escolas são promovidas com alunos em processo de formação, inclusive no que se refere à interação social, as propostas de atividades em grupo são muito relevantes para isso. Na esteira das atitudes que entendo fazer parte do trabalho em equipe, os alunos propõem soluções para problemas que podem surgir, quando já escolhem as histórias que pretendem filmar com base nas condições (infraestrutura, materiais, humanas) postas para eles, ao gravarem os filmes em espaço, tempos e condições que se enquadram na realidade escolar ou do projeto onde ocorre. Ao tomar parte das decisões o estudante pode expressar suas ideias, mostrando-se partícipe daquele grupo, e ao manter os acordos feitos pelo grupo, contribui para um bom andamento da oficina, seguindo aquilo que foi planejado coletivamente.

Dentro da capacidade de escuta está a empatia, pois na interação comunicativa, ao ouvir o outro recorremos a atitudes para demonstrar que o que está sendo comunicado foi entendido e teve relevância (ou não) naquele momento. Entre as atitudes que demonstram a capacidade de empatia, está a postura atenta em relação ao outro (ouvir as opiniões, mesmo que discordando), para demonstrar que se está disposto a compreender o que está sendo dito. Nas oficinas, a mediação de conflitos entre participantes geralmente fica a cargo do professor, mas por vezes os alunos com postura de liderança assumem esse papel, que demanda empatia para compreender a situação de cada lado e, assim, negociar opiniões para chegar a uma solução satisfatória para todos.

A capacidade de planejamento de tarefas observando os prazos é desenvolvida quando o grupo necessita organizar as atividades respeitando o tempo disponível, dividindo as etapas da oficina: quando precisam resolver em quanto tempo terminarão o roteiro para, em seguida iniciar as filmagens e depois a edição do filme, por exemplo. Para tanto, os alunos precisam distribuir as tarefas entre os participantes. O cumprimento dessas tarefas dentro do prazo 
depende de cada um para que o resultado final seja alcançado a contento e o trabalho em equipe tenha logrado êxito.

A capacidade de argumentação pode ser observada na oficina de produção audiovisual escolar, quando o estudante expressa uma ideia com clareza para o outro, defendendo uma proposta com bons argumentos. Essas atitudes geralmente ocorrem quando eles indicam que a cena ficará melhor se for feita por um ângulo específico, por exemplo. Caso uma ideia não seja compreendida, é preciso mudar o argumento anteriormente usado para explicála de maneira mais clara e até incorporar ideias dos outros para reelaborar o argumento inicial que não foi compreendido - essas argumentações ocorrem muitas vezes na defesa de ideias para os roteiros, quando os alunos elaboram ações dos personagens e é preciso defender seu ponto de vista.

Também é necessário ter capacidade de argumentação para defender suas opiniões e escolhas sobre aspectos relacionados à transposição de linguagens, por exemplo, ou seja, ao modo como uma ideia expressa em linguagem oral é transposta para o roteiro ou no modo como uma cena é gravada tendo como base o que está escrito no roteiro. Ao produzir audiovisual na escola, os alunos são convidados a transcodificar diferentes linguagens ao escrever um roteiro, que antes era apenas ideias narradas por coletivamente; pensar como a história será contada em imagens, pelas ações das personagens e os figurinos usados por elas, pela luz escolhida para as cenas, pelas músicas e sons usados para despertar diferentes emoções em quem assistirá ao filme. Essas constituem, a meu ver, habilidades estéticas, sintetizadas, no trabalho de campo, do seguinte modo:

\begin{tabular}{|c|c|}
\hline & Atitudes \\
\hline $\begin{array}{c}\text { Habilidades } \\
\text { estéticas na } \\
\text { produção } \\
\text { audiovisual }\end{array}$ & $\begin{array}{l}\text { Sugerir mudanças no cenário para melhorar o enquadramento da } \\
\text { cena } \\
\text { Sugerir posicionamento da câmera para melhorar enquadramento } \\
\text { Sugerir mudanças na iluminação } \\
\text { Indicar figurinos ou tipos de maquiagem para melhor retratar a cena } \\
\text { Sugerir melhor posicionamento de atores e figurantes para as cenas } \\
\text { Sugerir mudanças para melhorar o som da filmagem }\end{array}$ \\
\hline 7 & $\begin{array}{l}\text { habilidades sociocognitivas e atitudes envolvidas } \\
\text { scolar } \\
\text { a. }\end{array}$ \\
\hline
\end{tabular}

Elenquei essas habilidades e atitudes para esclarecer como elas podem ser mobilizadas no processo de produção audiovisual na escola, porém, essas ações não ocorrem de maneira linear e geralmente uma habilidade se articula a outras para ser desenvolvida. Este é, portanto, um processo cognitivo e, como 
tal, não segue um protocolo único nem predeterminado, tanto que algumas das habilidades indicadas a partir da base teórica não foram observadas na pesquisa de campo, conforme veremos no capítulo de análise.

O que é possível dizer sobre o desenvolvimento de habilidades sociocognitivas no processo de produção audiovisual na escola é que este ocorre por meio da interação dos sujeitos envolvidos entre si, com os equipamentos, com a linguagem (propriamente dita e cinematográfica), seguindo determinadas regras postas nas relações dos sujeitos dentro do ambiente educativo.

O olhar que proponho para capturar pistas ou indícios ou mesmo evidências mais sólidas de habilidades sociocognitivas cujo desenvolvimento possa ser favorecido nos processos que envolvem a produção de audiovisual com crianças, não tem a intenção de mensurar ou quantificar, mas de produzir um registro do aparecimento progressivo dessas habilidades, no decorrer das atividades realizadas na oficina de produção. Compreender quais habilidades estão envolvidas nesse processo pode ajudar os professores a planejar intencionalmente atividades que favoreçam o desenvolvimento delas, como parte de seus objetivos ao propor a realização de vídeos/filmes na escola, o que certamente contribuiria também para melhorar a aprendizagem dos conteúdos escolares. 


\title{
6 \\ Oficina de produção audiovisual: pedagogia do professor
}

Quem observa o faz de um certo ponto de vista, o que não situa o observador em erro. O erro na verdade não é ter um certo ponto de vista, mas absolutizá-lo e desconhecer que, mesmo do acerto de seu ponto de vista é possível que a razão ética nem sempre esteja com ele. (Paulo Freire, 1996, p. 14).

Nesse primeiro eixo de análise, apresento os pressupostos que dirigem as ações pedagógicas do professor em relação à oficina de vídeos que promove na escola, destacando: a) estratégias pedagógicas adotadas por ele; b) método de ensino; c) modos de agir em sala de aula; d) a maneira como mobiliza os alunos em suas propostas; como enuncia a atividade; como se dirige aos alunos; como motivou os alunos para a realização das atividades necessárias à produção do vídeo. A proposta desta análise não tem por fim avaliar/criticar o que o professor fez durante a oficina, mas discutir as atividades realizadas, à luz das pedagogias audiovisuais arroladas no capítulo teórico.

$\mathrm{Na}$ entrevista que realizei com o professor após a oficina, ele relatou o quanto achou importante minha presença durante aquele ano observando sua prática, vendo isso como uma oportunidade de compreender melhor como está funcionando seu trabalho:

\begin{abstract}
Eu sinto muito falta disso, assim, sabe, assim, eu não sou um cara muito acadêmico, eu não tenho uma vida muito... Eu sou muito da prática, tudo que faço eu aprendi muito na prática, essa parte toda, e de uma certa maneira eu sinto falta de observar outras possibilidades, ou entender melhor até... É o trabalho que eu faço e outros colegas fazem, entendeu? Porque a gente não tem muita coisa disso ainda, né, não tem muitos estudos, muita pesquisa sobre isso. Até pra que eu entenda mesmo até onde está funcionando, como é que é... Sabe? E é bom ter o olhar de fora que está ali, observando, dedicado a fazer isso, porque muitas vezes eu estou na aula, estou pensando em milhões de coisas e eu deixo escapar coisas que um olhar atento, como o seu, que está lá só pra isso consegue perceber e consegue de repente avaliar e pensar melhor e entender o processo. Entendeu? Então, eu acho bom, assim. Então, eu fico bem feliz de ter participado disso, de ter contribuído, espero que realmente contribua e ajude vocês. (Professor Jonas).
\end{abstract}

Com base nessa fala do professor, nesse momento me coloco não como uma avaliadora de uma oficina implementada por ele nessa escola há mais de 15 anos, mas uma pesquisadora a quem foi permitido observar seu trabalho e analisá-lo para, por fim, contribuir com algumas ideias, minhas e de outros pesquisadores, que embasam a criação de vídeos na escola. Busquei ao máximo não fazer uma análise que desmerecesse o trabalho, mas que 
retribuísse de alguma maneira a ele, aos alunos e à escola como um todo a maneira como fui recebida durante todo esse tempo.

Ainda durante a pesquisa Mídia-Edu, quando estive em algumas escolas da prefeitura do Rio de Janeiro, em 2016, realizei uma entrevista com esse professor, que mais tarde veio a ser sujeito desta pesquisa. Ao perguntar sobre seu objetivo com as oficinas de produção de vídeos, ele respondeu:

No início, uma das coisas que eu pensei muito era trabalhar com a possibilidade de dar voz a esses meninos. Quando eu comecei a fazer aulas de teatro, eu levava textos de autores conhecidos e a gente adaptava, muitas vezes, e representava, fazia as peças. Com o vídeo surgiu uma possibilidade diferente: eles produzirem o conteúdo todo, produzirem os vídeos, produzirem todas as coisas. Então a minha ideia era que eles pudessem ter voz, chegar e colocar ideias não só de filmes de ficção, mas documentários - a gente fez várias experiências -, então que a gente pudesse falar de assuntos que interessassem a eles. (Professor Jonas).

O professor vê nessa oficina uma maneira de dar visibilidade aos alunos por meio de algo feito por eles mesmos:

Então eu descobri que isso poderia ser uma possibilidade bacana, de produzir algo que realmente fosse a cara deles. Apesar de ter uma influência grande minha de orientar, as ideias surgem da cabeça deles. [...] O objetivo maior é esse: fazer com que eles possam colocar no ar, na rede, ou pra outras escolas, pra outros jovens, ou pra sua própria escola, exibir para seus amigos algo que tenha sido pensado totalmente por eles, assim, feito por eles e para eles. Essa é a ideia principal. (Professor Jonas).

A intenção de deixar os alunos falarem/se expressarem através dos filmes é um objetivo muito presente em atividades que envolvem o cinema na escola (Dall'Agnol, 2015; Hobbs \& Moore, 2014; Menezes, Adrião \& Rios, 2017). De acordo com Pires (2014), as oficinas de vídeo se apresentam como um espaço diferenciado onde os jovens podem falar e serem ouvidos na escola e na comunidade.

No início do trabalho de campo, perguntei ao professor se ele havia apresentado um projeto a alguma instância superior, ou mesmo às escolas em que atuava, para implementação das oficinas de vídeo. A resposta dele foi de que havia construído um projeto em 2008 e apresentado à $C R E^{51}$, que aprovou as atividades e, desde então, ele passou a ministrar essas oficinas. Ainda naquela oportunidade, solicitei ao professor uma cópia, mas ele não me enviou, pois o documento estava em um computador antigo que apresentou defeito.

${ }^{51}$ Coordenadoria Regional de Educação, órgão regional, vinculado à Secretaria Municipal de Educação, responsável pela gestão educacional em segunda instância. 
Para compreender o que estava estruturado como proposta para a oficina, tratei disso na entrevista (ao término da oficina) com ele e sua resposta sobre seus objetivos foi a seguinte:

Então, na verdade o objetivo da oficina, eu tento todo ano trabalhar em cima do mesmo objetivo, né? Principal, que é dar oportunidade deles vivenciarem o processo de criação de um produto audiovisual, mas também em determinados momentos eu procuro ter alguma outra especificidade, se tiver um tema específico, ou alguma coisa que a gente queira trabalhar naquele ano, alguma demanda da escola... No ano de 2017, a gente não teve isso, ficou simplesmente no objetivo principal, que era trabalhar essa possibilidade deles experimentarem e vivenciarem esse processo com uma ênfase grande na parte da escrita, na produção textual, que é aquele primeiro bimestre onde a gente trabalha mais focado nisso. (Professor Jonas).

O foco era, portanto, a criação de um produto com ênfase na parte escrita. Esse destaque é relevante para compreendermos como se desenrolaram as atividades da oficina e de que maneira a prática correspondeu a esses objetivos.

A análise do material empírico produzido no trabalho de campo permitiu identificar o que se mostra como uma pedagogia de produção audiovisual, consolidada por esse professor - digo "consolidada" porque o próprio professor apresentou essa metodologia como algo desenvolvido por ele ao longo de sua experiência com a criação de filmes na escola, sendo atualmente aplicada nas diferentes oficinas que ele promove, tanto na rede municipal carioca, como em uma escola particular da cidade ${ }^{52}$. Como informado pelo professor, ele ministra oficinas de vídeo na escola pesquisada desde 2003 e já participou de diversos eventos e festivais com os filmes produzidos pelos alunos, tendo alguns vídeos selecionados ou premiados ${ }^{53}$. Sua proposta metodológica consiste, principalmente em:

no primeiro bimestre, a gente trabalha com uma interação entre eles... depois trabalha mostrando alguns filmes que eles... que a escola já realizou em outros anos e de outras escolas em que eu trabalho... Tem esse primeiro contato com o audiovisual pra eles conhecerem, entenderem o método, um pouco, falo um pouco de como a gente vai trabalhar. E aí a gente cai já na parte de brainstorming, da elaboração das ideias, onde eles são solicitados a trazer ideias para os filmes, já peço que essas ideias venham em 5 linhas. Eu peço sempre que eles tragam uma sinopse rápida de 5 linhas, onde a gente consiga facilmente entender o que ele quer dizer com aquela história nesse primeiro momento. Depois, ainda no primeiro bimestre, a gente evolui para um argumento mais detalhado e depois disso a gente avança pro segundo bimestre, onde a gente parte pra escrita de fato do roteiro, e terceiro bimestre seriam as gravações, e o quarto bimestre, finalização das gravações e a edição. Seria essa a proposta inicial. (Professor Jonas).

\footnotetext{
52 O professor comentou diversas vezes que dava essa mesma oficina em uma escola na Barra da Tijuca, onde leciona há alguns anos e em outras duas escolas da rede municipal.

53 Alguns eventos que o professor indicou ter participado: 2을 Festival de Cinema Escolar de Alvorada-RS, Festival Internacional Pequeno Cineasta, Vídeo Fórum da Mostra Geração - Festival do Rio, Mostra Competitiva Nacional do $7^{\circ}$ Festcine Estudantil de Barra do Piraí, todos em 2016, e 1ํ Festival de Cinema Escolar de Alvorada-RS, em 2015.
} 
De acordo com essa proposta apresentada pelo professor, as atividades seriam divididas da seguinte forma:

\begin{tabular}{|c|l|}
\hline Bimestre & \multicolumn{1}{c|}{ Atividade } \\
\hline $1^{\circ}$ & - Visualização dos filmes produzidos nessa e em outras escolas \\
& - Brainstorming das ideias \\
& - Desenvolvimento do argumento \\
$2^{\circ}$ & - Escrita do roteiro \\
$3^{0}$ & - Gravações \\
$4^{\circ}$ & - Finalização das gravações e edição \\
\hline
\end{tabular}

Quadro 8 - Planejamento da oficina apresentado pelo professor

Fonte: Elaboração própria.

No quadro a seguir, apresento as atividades realizadas e o período em que foram desenvolvidas, conforme observei no trabalho de campo:

\begin{tabular}{|c|c|c|c|}
\hline Bimestre & Período & Atividade proposta & Momentos \\
\hline $1^{0}$ & março & $\begin{array}{l}\text { Exibição dos filmes realizados } \\
\text { por alunos da escola em } \\
\text { oficinas dos anos anteriores }\end{array}$ & $\begin{array}{l}\text { (Indicado que foi feito, porém, } \\
\text { não observado) }\end{array}$ \\
\hline $1^{0}-2^{0}$ & $\begin{array}{l}\text { 12/abr. a } \\
\text { 24/maio }\end{array}$ & Definição da história do filme & $\begin{array}{l}\text { Levantamento de ideias } \\
\text { Escolha da história } \\
\text { Composição das personagens }\end{array}$ \\
\hline $2^{\circ}$ & $\begin{array}{l}\text { 30/maio a } \\
4 / \text { jul. }\end{array}$ & Escrita do roteiro & $\begin{array}{l}\text { Aula explanatória sobre as } \\
\text { partes de um roteiro } \\
\text { Escrita propriamente dita }\end{array}$ \\
\hline $3^{0}$ & $\begin{array}{l}\text { dia 5/set. } \\
\text { 5/set. a } \\
\text { 12/set. }\end{array}$ & $\begin{array}{l}\text { Linguagem audiovisual } \\
\text { Divisão dos papéis e atividades } \\
\text { para a filmagem e ensaios }\end{array}$ & $\begin{array}{l}\text { Vídeo apresentando a sintaxe } \\
\text { da narrativa cinematográfica } \\
\text { Escolha dos atores e teste de } \\
\text { papéis }\end{array}$ \\
\hline $3^{\circ}-4^{o}$ & $\begin{array}{l}\text { 17/out. a } \\
\text { 5/dez. }\end{array}$ & Filmagens & Filmagens internas e externas \\
\hline
\end{tabular}

Quadro 9 - Atividades da oficina - momentos e períodos

Fonte: Elaboração própria.

Comparando o planejamento do professor (Quadro 7) e o que foi observado (Quadro 8), é possível perceber que os períodos estabelecidos para as atividades foram cumpridos dentro do planejado, porém, em minha estadia nas oficinas, como pesquisadora, não observei a exibição de filmes realizados em oficinas anteriores e nem a edição do filme produzido nessa oficina. Além disso, a veiculação do vídeo realizado na escola também não aparece no planejamento nem nas atividades observadas durante a oficina.

As atividades propostas pelo professor parecem se aproximar da metodologia proposta na pedagogia audiovisual da mídia-educação, que indica a organização do trabalho em etapas: definição da história a ser contada, escrita do roteiro, divisão da equipe, filmagens e edição (Fantin, 2014; Husbye, 2013; Miranda, 2015; Pimentel, 2013; Pires, 2014), com base na ideia de que é importante simular o processo de produção audiovisual profissional. De acordo com Hobbs \& Moore (2014, p. 25): 
Alguns jovens educadores de mídia têm a preocupação de que imitar os gêneros convencionais de Hollywood pode limitar a criatividade e a imaginação dos jovens e incentivá-los a se concentrar no domínio da competência técnica em composição de cenas, iluminação, som e edição, contribuindo para o que Masterman (1985, p. 23) chamou a armadilha tecnicista, um temor de que os educadores negligenciem a análise crítica textual de obras quando são altamente treinados nas artes da produção audiovisual e enfatizam os aspectos técnicos da produção de mídia. ${ }^{54}$

Embora se possa supor, pelas atividades realizadas, que essa perspectiva baseia a pedagogia adotada pelo professor, a sala onde ocorre a oficina tem no quadro a seguinte frase de Alain Bergala, autor referência do campo de cinemaeducação:

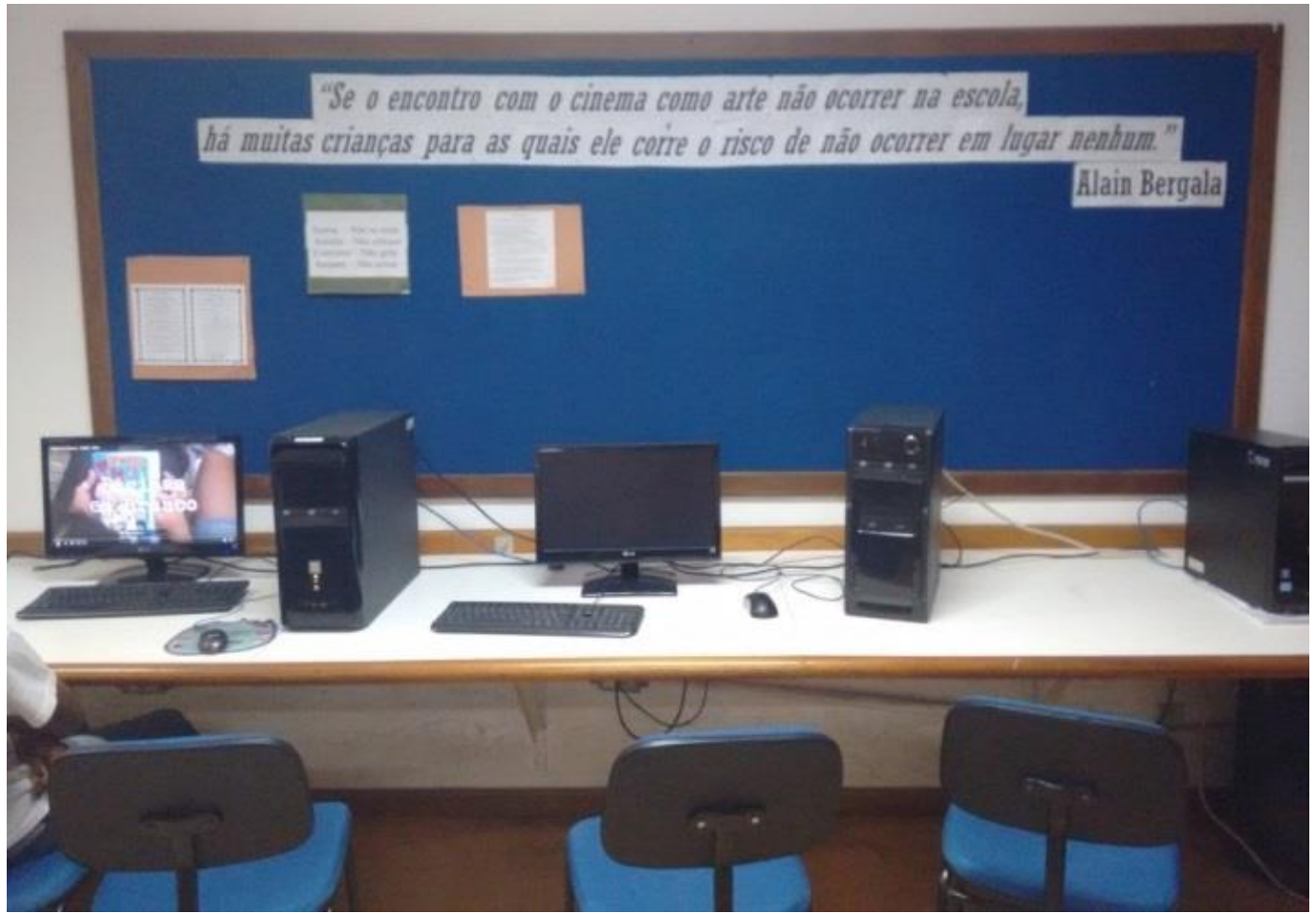

Figura 18 - Quadro na sala onde ocorre a oficina de vídeo na escola pesquisada Fonte: Arquivo da pesquisadora.

A perspectiva teórico-metodológica das atividades promovidas na oficina não estava ancorada na vertente de cinema-educação, conforme era esperado a partir da exposição dessa frase na sala. Apresento, a seguir, os momentos da pedagogia audiovisual do professor.

54 Tradução minha do original: "Some youth media educators have concerns that imitating conventional Hollywood genres may limit the creativity and imagination of young people and encourage them to focus on the mastery of technical competence in shot composition, lighting, sound, and editing, contributing to what Masterman (1985, p. 23) has called the technicist trap, a fear that educators neglect critical textual analysis of works when they are highly trained in the arts of audio visual production and emphasize the technical aspects of media production." 


\section{* Ver filmes}

Essa atividade, embora integre o planejamento do professor, não foi observada no trabalho de campo. Após minha primeira visita à escola, no dia 8 de março - quando não houve oficina porque o professor faltou - só retornei a campo no dia 12 de abril, pois o professor solicitou que eu não retornasse à escola até que ele pudesse organizar as turmas e fazer um primeiro contato com os alunos. Ele comentou que durante esse período, iniciou com as turmas já formadas a primeira parte da oficina, exibindo os filmes de alunos dessa e de outras escolas em que ele promove a oficina.

Logo que retornei à escola, em abril, alguns alunos comentaram que nessas aulas iniciais viram os filmes cujos cartazes estavam afixados na sala, mas outros disseram não ter participado dessas aulas, o que sugere que a exibição de filmes não chegou a ser uma atividade de que todos participaram provavelmente porque as turmas ainda estavam em processo de organização. Além disso, o professor passou apenas filmes feitos nas oficinas que ele ministrou nas escolas, com base em sua própria proposta, sem apresentar outras possibilidades de uso da linguagem audiovisual e de criação artística com imagens em movimento, indicadas como extremamente relevantes para o início desse processo, tanto por pesquisadores da mídia-educação (Fantin, 2014; Nakache, 2011; Toledo, 2014) quanto do cinema-educação (Fresquet, 2013; Norton, 2013). No decorrer da oficina, o material visto era mencionado pelo professor ou por alguns alunos com o argumento de que determinada ideia já havia sido tratada em vídeos feitos naquela escola. De acordo com Pires (2014, p. 168), passar os vídeos feitos nos próprios projetos é uma prática recorrente:

Exibe-se, em geral, curtas ou longas-metragens brasileiros, possivelmente até vídeos feitos em outras oficinas - do próprio projeto ou outros similares -, ou realização de uma atividade análoga, voltada para despertar a sensibilidade dos alunos.

Embora Jonas não tenha comentado isso comigo, acredito que o objetivo dessa abordagem de vídeos feitos naquela escola em anos anteriores seria o de estimular a turma a criar seu próprio filme, pois os estudantes viam materializado o resultado da proposta que o professor apresentava naquele momento para eles, com o sentido de mostrar o que eles poderiam fazer juntos naquela oficina. Outras pesquisas que apresentam projetos de produção de vídeos na escola também não mencionam atividades de assistir a filmes antes de partir para a produção, iniciando a proposta pela criação do roteiro, na mesma linha do 
professor observado (Husbye, 2013; Menezes, Adrião \& Rios, 2017). Kearney \& Schuck (2005) destacam que tarefas autênticas e contextualizadas corretamente, inclusive a apresentação de filmes realizados pelos professores em oficinas anteriores, podem "criar pontos pertinentes, estimular ideias para novos projetos e modelar linguagem apropriada"55 (p. 8) para a oficina que se inicia.

A pedagogia audiovisual do campo que aqui denominamos cinemaeducação entende a etapa de ver filmes como condição primordial para a passagem ao ato criativo (Bergala, 2008), propondo exercícios de visualização de planos, observações repetidas e atentas de cenas para compreender a visão que o diretor tem da cena antes de filmá-la, numa tentativa de imaginar cenários, movimentos, escolhas e as decisões que foram tomadas para que tais ações ocorressem daquela maneira, resultando no que compõe o filme. Para a o campo da mídia-educação, a análise de filmes tem por principal objetivo revelar os discursos e escolhas (ideológicos) dos cineastas, podendo ser um bom momento para debates em sala de aula (Fantin, 2014) sobre diversos temas que poderão ser tratados na produção audiovisual.

Como os tempos escolares nem sempre possibilitam a visualização de longas-metragens, propõe-se a exibição de curtas-metragens, de partes de filmes ou de planos. Após assistirem aos filmes, os alunos podem categorizá-lo em relação ao seu tipo (drama, comédia, suspense, documentário), abordar os temas tratados, discutir sobre como cada um foi afetado pela história, imaginar de que outras maneiras contariam aquela história e localizar aquele filme na história do cinema e na cinematografia de seu cineasta. Além disso, eles podem contar o que viram, sendo este um exercício de ver instigador para discussões sobre filmes na escola. Como propõe Adriana Fresquet, ao término do filme passado na escola, é mais válida a pergunta: "O que você viu?" do que: "O que você achou?". A primeira permite que o aluno conte, do seu ponto de vista, o que lhe chamou atenção no filme, enquanto a outra incita julgamentos (sobre o filme, os personagens, as escolhas do diretor, entre outras).

Há diversas maneiras de ver um filme na escola e de produzir também, porém, com base na proposta de Bergala (2008) e outros (Fresquet, 2013; Migliorin, 2015; Norton, 2013), a criação de filmes na escola não pode ficar aprisionada a narrativas e pedagogias que só podem ser acessadas pelo contato

55 Tradução minha do original: "[...] to make pertinent points, spark ideas for new projects and model appropriate language." 
com os filmes já realizados antes daqueles que nos propomos a produzir. Ver tem como principal objetivo "ensinar a criar". O cinema, como elemento de nossa cultura, instaura-se no mundo como uma janela luminosa através da qual conhecemos discursos, mundos, culturas, línguas e também aprendemos modos de expressar nossas ideias com imagens. Isso só é possível no contato com filmes de diferentes origens e que resultem de diferentes modos de composição de imagens.

Em sua hipótese-cinema, Bergala (2008, p. 34, 35) indica que é preciso "aprender a tornar-se um espectador que vivencia as emoções da própria criação", pois "Olhar um quadro colocando-se as questões do pintor, tentando compartilhar suas dúvidas e emoções de criador, não é a mesma coisa que olhar o quadro se limitando às emoções do espectador." Para isso, é preciso passar a um nível mais exigente do que "apenas" assistir ao filme como entretenimento e questionar o seu modo de construção. De receptor, passa-se a receptor atentoquestionador-criador. Para esse autor, essas etapas são necessárias para a construção do olhar e, portanto, dos modos de contar. Nenhuma delas é possível sem ver pelo menos um filme com ajuda de um mediador que encaminhe essa proposta.

Como já mencionei anteriormente, Bete Bullara (2018) considera que para produzir filmes melhores é preciso ver mais filmes, assim como é preciso ler mais para escrever melhor. A oficina de produção audiovisual na escola pode ser o único lugar em que os alunos tenham possibilidade de ver filmes com narrativas que se diferenciem daquelas que acessam na TV, na internet e no cinema. Essa é uma oportunidade de propiciar aos estudantes outro olhar para o cinema, mostrando as diversas maneiras (documentário, ficção científica, animação, etc.) e abordagens (ângulos, ritmos, sons) de falar sobre um mesmo assunto, por exemplo.

Um dos guias didáticos de cinema na escola, publicado pelo British Film Institute (s/d, p. 1), elenca dez mensagens-chaves sobre o tema, com base em resultados de projetos de cinema em contextos educativos. Algumas delas tratam da importância de ver filmes na escola:

1. Filme é sobre aprendizado ativo. A melhor educação cinematográfica inclui discussão, apresentação, pensamento crítico, trabalho em equipe e cinema, bem como assistir. [...] 5. O cinema é uma forma de arte. A educação cinematográfica leva os jovens além de Hollywood para o cinema mundial, o cinema independente britânico ou documentários - mas primeiro eles precisam ser apresentados a eles. 
Portanto, mesmo que os objetivos da exibição de filmes sejam diferentes para as vertentes que tratam do cinema na escola, é fato que estas reconhecem a relevância de ter um contato com filmes antes de se passar à produção deles.

A oficina iniciou-se em meio a muitas interrupções de aulas pelas paralisações no município e reuniões de professores durante a semana, o que poderia justificar a falta de tempo para as turmas verem filmes, porém, não houve comentários por parte do professor sobre a não exibição de filmes aos alunos, o que sugere que esse não era um foco dele.

\section{* Levantamento de ideias para o filme}

Quando iniciei a observação das oficinas, o professor já havia começado o processo de escolher, junto aos alunos, um mote/argumento para construção da história para o filme. Os alunos foram solicitados, na aula anterior, que pensassem em algum assunto e desenvolvessem uma breve história sobre ele. Essa proposta se dividiu em dois momentos que ocorreram em aulas diferentes.

$\mathrm{Na}$ primeira aula dessa proposta, Jonas pediu que os alunos apresentassem suas histórias. Alguns tinham mais de uma história escrita e outros escreveram ali mesmo ou contaram simplesmente, sem se guiar por nenhum texto escrito, inventando naquele momento. Enquanto contavam suas histórias, o professor perguntava como se desenrolariam os fatos e mostrava o que não estava bem construído ou as falhas nas histórias. Destacou impossibilidades de filmagem das histórias contadas, pela grandiosidade dos cenários, a falta de equipamentos necessários ou a grande quantidade de personagens e figurantes - como na proposta de um filme que se passava em um estádio de futebol, ou outra de uma corrida de carros. Quando as histórias eram interessantes, o professor elogiava e dizia como seria a filmagem das cenas.

Enquanto os alunos contavam suas ideias, o professor explanava sobre a importância de levarem em conta: um tema que se ambiente na escola, já que eles dispunham apenas desse espaço para filmar; personagens que permitissem a participação de todas as pessoas da oficina como atores ou figurantes; histórias que pudessem ser construídas com os recursos que eles dispunham de equipamentos, figurinos, etc., e contassem casos verossímeis, com início, meio e fim.

Ele ressaltou várias vezes a necessidade de "visualizarem" suas histórias, porém todo esse processo foi realizado sem uso de imagens. A visualização 
proposta deveria ocorrer através da imaginação e do discurso. Quando contavam os acontecimentos, o professor perguntava sobre determinado aspecto e o aluno respondia ali, na hora, resolvendo os problemas sem elaborar muito aquela situação, com respostas rápidas e a criação tomando corpo durante o processo discursivo:

Os alunos começam a ler suas histórias e os colegas passam a dar opiniões sobre estas. Taís sempre se coloca em relação às histórias dos outros, dando sua opinião, dizendo o que falta, como clímax, e dando ideias. Ela às vezes grita e interfere os outros com suas colocações; sempre entra em conversas paralelas, mas quando solicitada, demonstra que está entendendo tudo. Enquanto os alunos falam de suas histórias, o professor faz perguntas sobre suas histórias e como se resolvem certos aspectos. Há momentos em que parte da turma fica de fora da discussão, mas em outros, uma aluna da parte que não estava participando dá ideias para os outros que estavam conversando. As histórias deles giram em torno de temas como: bullying, namoro, riqueza e depressão. Quando alguém da parte mais envolvida da turma na atividade conta sua história, as colegas ajudam, dando ideias como se já fizessem parte da história contada. Uma garota do outro lado da mesa, de fora do grupo, pela segunda vez dá uma ideia para resolver a história que está sendo inventada pelas outras. (Diário de campo, visita 3.2).

Assim, conforme contavam as histórias, o professor, junto com a turma, levantava os problemas para desenharem melhor as ações pensadas, dentro da proposta de um filme. Não havia nenhum aluno responsável por anotar as ideias que surgiam naquela hora, nem o professor estava gravando em áudio essa conversa para retomarem depois.

A metodologia de geração de ideias para o filme seguiu essa dinâmica nas cinco turmas observadas no início do trabalho de campo. Como em toda proposta pedagógica, não há uma forma única para a realização desse tipo de atividade. Toledo (2014) indica que a partir de filmes vistos com os estudantes, pode-se propor a escrita de ideias parecidas com o que assistiram para a construção de um argumento e, assim, a turma pode escolher aquela que servirá de enredo para o vídeo. Em oficina sobre representações juvenis em filmes de grande bilheteria, Machado (2017) propôs aos alunos assistirem a filmes, discutir sobre eles e, a partir dos debates, surgiu o mote para a produção de um vídeo que, por escolha dos participantes da oficina, tratava de outro tema. Isso indica que a escolha do tema a ser abordado depende de vários fatores, entre os quais o objetivo da oficina. Em projetos que tratam de temas específicos (drogas, sexualidade, tráfico, violência), os estudantes ficam mais livres para criarem a história; em propostas de criação de vídeos sobre temas curriculares, há um maior direcionamento por parte do professor, mas mesmo assim os alunos precisam organizar as ideias de modo que a construção do vídeo atenda ao que foi solicitado. Em oficinas livres, como a observada nesta pesquisa, o tema é 
definido pelos alunos, após discussões e escolhas da turma sobre o que vão tratar.

O levantamento de ideias para a história coletiva pode ser um importante momento para conhecer a realidade dos alunos e suas opiniões sobre os temas que surgem nessas conversas:

Descobrimos que no momento em que as crianças produzem seus exercícios e filmes, elas trazem para dentro da escola seus mundos de uma maneira singular, estética e mediada. Enquanto por vezes o funk, a violência, a relação com a igreja e outras manifestações do universo das crianças são apenas desconsideradas ou proibidas, quando essas questões aparecem pelo cinema, esses mesmos elementos são deslocados da coisa em si para serem discutidos como representação, como aquilo que é parte da comunidade, permitindo e convocando o trabalho dos professores. Nesse sentido, debates sobre questões como bullying, drogas e violência se tornam mais eficazes e reveladoras quando aparecem através de uma narrativa, de uma ficcionalização ou pela voz dos estudantes. (Migliorin, 2015, p. 153).

$\mathrm{Na}$ oficina observada, os alunos apresentaram histórias sobre namoro, bullying, riqueza, depressão e suicídio. Um aluno do 9a ano contou uma história sobre tentativa de suicídio e automutilação. O professor lhe perguntou se essa história era inspirada em uma história real, e o aluno acabou confirmando que era sobre a vida dele, mas não entrou em detalhes. Percebi que o professor se aproximou desse aluno que sempre esteve presente nas aulas e trazia várias histórias, pois dizia gostar de ler e de escrever ${ }^{56}$. Essa situação mostra que, ao propor narrativas livres no ambiente escolar, é possível que os alunos tragam (também) para debate questões dolorosas de suas vidas pessoais, sendo necessário um olhar atento do professor sobre isso, em busca de auxiliar da melhor maneira possível os estudantes. Ao comentar como uma cineasta lidou com uma aluna que trouxe questões de saudade e sofrimento para a oficina de audiovisual, Pacheco (2015, p. 232) pondera que:

Os miúdos andam sedentos por poderem se expressar, expressar seus sentimentos, pensamentos, suas angústias, as angústias e sofrimentos de seus pais, de suas famílias, e da vida. Pois a vida contemporânea requer novas formas de agir, de lidar, de ensinar e aprender. Eles querem saber, conhecer, saber o porquê, compreender. Os educandos deste novo milénio não aceitam mais fazer por fazer, querem compreender para poderem cooperar.

Não soube se o professor levou o caso desse aluno ao conhecimento da coordenação ou orientação escolar para um acompanhamento mais próximo, como deve ser feito em situações desse tipo. Como fazia parte de uma turma desistente, logo nos primeiros meses não tive mais contato com ele.

\footnotetext{
${ }^{56}$ Soube pelo professor que esse aluno foi convidado a participar das aulas com outra turma que
} já havia feito oficina no ano anterior e estavam terminando um filme iniciado em 2016. 
Muitas ideias apresentadas pelos estudantes eram parecidas com aquelas já abordadas em filmes anteriores na escola ou em séries bastante conhecidas. Durante a apresentação das histórias, uma aluna contou o que se passa no filme D.U.F.F. ${ }^{57}$, como se a história fosse dela. Os alunos contaram histórias de filmes, como Moonlight e La la land ${ }^{58}$, como histórias bonitas e interessantes para abordarem em seus filmes. A meu ver, o professor poderia ter aproveitado esse momento para apresentar trechos desses filmes e propor outras formas de abordagem dos mesmos temas, além de exibir trechos de outros filmes, com temas e formatos diferentes, para estimular os estudantes a pensarem um tema original ou forma original de abordar assuntos já tratados.

\section{* Escolha da história}

Quando as histórias já estavam melhor organizadas, o professor propôs aos alunos que contassem suas histórias, mas dessa vez, isso foi filmado: cada aluno se posicionava frente à câmera e contava sua história. Em seguida, Jonas passou todos os vídeos para seu notebook e os alunos os assistiram. Conforme ouvia no vídeo o tema da história, o professor anotava uma frase que sintetizava cada uma das histórias apresentadas, indicando aos alunos como se dá a criação de um "argumento": "Menino rico que vai estudar na escola pública", "Garoto que sofre gordofobia", "Duas meninas que se apaixonam" etc. Enumerou no quadro os temas e solicitou que os alunos votassem em três histórias, cada um. Percebi, em todas as turmas que observei, que a votação geralmente era feita abertamente: todos falavam qual a história e o professor anotava no quadro a quantidade de votos. Porém, houve uma turma que não quis proceder dessa forma e o professor optou por voto secreto.

Com o decorrer da discussão, os alunos ficaram muito dispersos, conversando entre si, sem dar atenção à proposta da aula. $O$ professor solicitava a opinião deles, principalmente daqueles que não estavam ligados na aula. Nesse momento, o professor iniciou uma discussão sobre a falta de participação do grupo na oficina, perguntando: qual o objetivo deles, por que estavam ali? Os alunos ficaram em silêncio. $O$ professor insistiu e perguntou a um aluno específico, que estava usando fones de ouvido e de cabeça baixa durante as atividades: "Por que você está aqui se não participa e não responde nada?" E assim foi perguntando a outros alunos, enquanto os demais apenas assistiam a discussão e o professor ressaltava que a aula não estava interessante sem a participação deles no processo, querendo entender qual o problema dessas turmas de mais de 60 pessoas que não estavam vindo e os que vinham estavam zoando a aula. Ele destacou a importância desse momento para a oficina, pois é relevante escolher

\footnotetext{
57 Ari Sandel, EUA, 2015.

58 Ambos de 2016 e dos EUA, o primeiro foi dirigido por Barry Jenkins e o segundo por Damien Chazelle, ambos concorreram ao Oscar de melhor filme.
} 
bem a história que será a base do roteiro. [...] Depois disso, pediu que os alunos votassem nas ideias. Como os alunos não queriam falar, ele resolveu pela votação em papel, e cada um deveria votar em 3 ideias. O professor vota também. Durante a votação, os alunos voltam a rir e a brincar. Em seguida, o professor conta os votos, anotando-os no quadro. (Diário de campo - visita no 6).

Após isso, os alunos foram divididos em grupos que deveriam desenvolver uma das histórias mais votadas, resumindo os acontecimentos que poderiam ocorrer na narrativa proposta por aquele título. Por fim, eles apresentaram o que produziram e escolheram a melhor história, com base na facilidade para filmar e na preferência da maioria.

Quando observei essa atividade, perguntei-me sobre qual objetivo teria o professor ao filmar os alunos contando suas histórias e, em seguida, convidá-los a assistir a esses vídeos. Em aulas seguintes, esses vídeos foram acessados pelo professor durante suas aulas para lembrar quais as histórias que aquela turma havia apresentado. Portanto, o recurso do vídeo é usado para registrar e guardar as histórias das turmas. Isso é relevante para a organização do professor em relação à grande quantidade de turmas que tinha no início do ano. Esse momento poderia ser usado para que os alunos experimentassem a câmera, explorando, inclusive, diversos ângulos, sob o pretexto de filmar um colega contando sua história. Outra proposta seria pedir que os alunos contassem suas histórias encenando algum personagem, para, assim, a turma conhecer seus talentos e adiantar a escolha dos "atores" para o filme. Em ambas as propostas, o professor teria, ao final das atividades, os vídeos com as ideias de cada turma, atendendo também seu objetivo.

Durante a escolha da história, percebi que Jonas buscava convencer os alunos a escolherem a história mais exequível, levantando argumentos sobre como seria mais prático ter que filmar um jogo de pingue-pongue, por exemplo, do que alguém cavando uma cova no quintal. O professor trabalhava com as possibilidades que tinha a sua disposição dentro daquela realidade e suas escolhas objetivavam fugir dos problemas que ele já conhecia ou sabia que poderiam acontecer.

Nas discussões durante o desenvolvimento da história, Jonas ressaltava o quanto era necessário ter atenção com o tema escolhido, para que o foco de uma questão, como uma bola perdida, por exemplo, não fosse mais importante do que a morte de uma colega:

[...] a ideia de filme dessa turma é sobre um grupo de alunos que deixa cair uma bolinha de pingue-pongue na casa do vizinho. Durante a aula, os alunos sugerem mudar a história para que um suspeito mate uma colega da escola e o professor 
destaca a mudança de foco que saiu da busca pela bolinha perdida para um assassinato. Diante disso, explica aos alunos que a morte de uma colega é mais relevante do que perder uma bolinha de pingue-pongue. Os alunos, porém, continuam argumentando sobre a inclusão da cena da morte da colega na história. O professor fica bem reticente com o caminho que a narrativa tomou. Ele explica, então, como a história muda, indo por esse caminho, e mostra elementos falhos, como o fato de haver uma colega morta e eles só pensarem em achar a bolinha perdida. (Diário de campo - visita 4.1).

Quando os alunos não aceitavam as mudanças propostas pelo professor, ele levantava argumentos na tentativa de fazê-los seguir sua orientação com explanações a respeito do que é certo, melhor e mais viável para um vídeo estudantil. Desse modo, o processo de escolha do argumento a ser filmado acabava tomando muitas aulas, pois os alunos apresentavam os temas, selecionavam as ideias possíveis, votavam nas que gostavam mais, escreviam argumentos para as mais votadas e, por fim, escolhiam uma para desenvolver o roteiro. Conforme indica Toledo $(2010,2014)$, esses processos demandam tempo e mediação atenta do professor para chegarem a uma decisão satisfatória para todos.

Menezes, Rios \& Adrião (2017) seguiram essa mesma lógica de levantamento de ideias para a escrita do roteiro do vídeo, mas destacam que ideias que surgem espontaneamente "dificilmente adquirem a estrutura de um vídeo bem elaborado, sendo insuficiente para construir um ponto de vista." ( $p$. 63). Os autores indicam ser mais produtivo partir de uma discussão com o grupo sobre o tema para o desenvolvimento de um bom roteiro que, na perspectiva defendida por eles, deve seguir a seguinte metodologia:

Após a reflexão sobre o tema, o grupo deve fazer uma coleção de ideias. Todos nós, ao longo da vidam passamos por situações ou conhecemos histórias que podem ser úteis para discutir os temas propostos. Cada jovem do grupo deve apresentar alguma história ou situação, que podem ser reais ou imaginadas, e é dessa coleção de histórias que o grupo deve estruturar a ideia do vídeo, ou seja, o roteiro. (Menezes, Rios \& Adrião, 2017, p.63).

Em atividades cujo objetivo é tratar de tópicos das disciplinas escolares também é possível escolher temas cujos conteúdos passem a fazer parte da história que será contada:

Na $3^{\text {a }}$ série do EM da escola onde trabalho, pedi que eles fizessem um trabalho em grupo sobre o tópico "bullying". Este tema havia sido trabalhado em aulas anteriores, nas quais ensinei diversos itens lexicais e de estrutura gramatical da língua inglesa partindo do assunto. Além disso, como forma de introduzir o tema, nós o havíamos discutido, inclusive em nível pessoal. A discussão foi fértil, o interesse pelo assunto cresceu e, no momento da avaliação, o formato do trabalho foi deixado livre. Demandei apenas que eles usassem o vocabulário e estruturas aprendidos. O resultado foi variado e rico: peças de teatro, apresentações em Power Point, pesquisas em comunidades na Internet de pessoas que sofreram 
bullying, vídeos de animação, fotonovelas e vídeos onde os atores eram os alunos. Um destes vídeos chamou a atenção pela qualidade da narrativa e pelo uso de uma linguagem de cinema que os alunos demonstraram entender: uso de flashback, cortes precisos para a construção da história, cenas em preto e branco para criar climas diferentes. Pela primeira vez, constatei que a confecção do vídeo na escola podia propiciar um caminho de aprendizagem complexo e precioso para o processo cognitivo dos alunos. (Labrunie, 2017, p. 12).

Os autores aqui citados destacam a relevância de discussões aprofundadas sobre os temas que serão tratados nos filmes. $\mathrm{Na}$ oficina observada, esses temas eram discutidos conforme a história estava sendo pensada pelos alunos. Por vezes, havia discussões mais aprofundadas sobre temas do interesse da turma:

Um dos alunos traz uma história sobre ele mesmo que sofre gordofobia na escola e arma um plano de vingança contra os outros. O professor problematiza sobre as ações do personagem principal, que poderia agir de maneira diferente de como o aluno reagiria em determinadas situações. Ele pede que o aluno explique melhor sua história, pois acha muito simples; pede que conte mais sobre como é esse personagem, como ele é tratado na escola, e como planeja a vingança. O grupo todo participa da maior parte das discussões sobre homofobia e racismo que surgiram em algumas histórias. A maior parte da aula foi uma discussão sobre relacionamentos homossexuais e o preconceito que ronda esse universo, levantando questões sobre: quem sofre mais preconceito - homem com homem ou mulher com mulher? Os alunos vinham trazendo suas impressões sobre o assunto e respondiam as questões do professor, ao mesmo tempo em que surgiam outras questões, como machismo e preconceito dos próprios alunos. A maneira como eles veem o relacionamento (beijo, abraço, mãos dadas) entre pessoas do mesmo sexo. Os alunos insistem que querem fazer um filme sobre preconceito e homofobia. O professor levanta uma discussão com base nos comportamentos dos próprios alunos e dentro da escola. Por fim, o professor levanta uma pergunta: será que estamos prontos para tratar certas questões que não estão resolvidas entre vocês? (Diário de campo - visita 5.2).

A partir daquela discussão, o professor percebeu que os alunos não poderiam tratar de um assunto que não estava bem definido para eles individualmente e como grupo. Embora essa turma tenha sido a única que discutiu mais atentamente um tema específico, não chegou a finalizar a oficina, o que sugere que as discussões aprofundadas, nesse caso, talvez não fossem suficientes para levar a proposta de produção audiovisual adiante.

\section{Composição das personagens}

No momento seguinte da oficina, após escolhida a história para o filme, o professor propôs que a turma falasse sobre como deveria ser cada um dos personagens, suas características, nomes, maneira de se vestir, entre outras marcas de sua personalidade. Nessa aula, ele apresentou para o grupo como é necessário haver diversas personalidades entre os personagens para construção 
de uma narrativa envolvente e bem construída. Deu exemplos de personagens de filmes ou novelas bastante conhecidos, para destacar como seria um personagem bobalhão, ingênuo, desenrolado, tímido, conquistador, entre outros. Todas essas explanações realizadas até aqui ocorreram em uma conversa com a turma: o professor trabalha com o esquema perguntas-respostas. Ele joga para a turma: "Como pode ser a personalidade da personagem principal, que sofre bullying na escola?" - e aguarda a resposta dos alunos que nem sempre participam. Em uma das turmas, os alunos pareciam não saber responder, então o professor resolveu pegar dicionários na sala de leitura para que eles buscassem características e descrevessem cada uma delas:

No grande grupo, o professor explica como eles devem pensar os personagens. Os alunos ficam atentos às instruções do professor e dão ideias aos poucos para seus personagens. As meninas não falam nada e parecem ter vergonha, pois riem e falam baixo, como se estivessem envergonhadas. O professor faz uma ponte entre os perfis dos alunos na escola e alguns personagens de comédia. Os meninos dão algumas ideias, mas ainda falam baixo, parecem não ter certeza do que dizem. Aos poucos, as meninas passam a falar mais. $O$ professor liga a história a possíveis perfis de personagens. Eles não sabem o que dizer quando o professor pergunta o que são as características de alguém, sendo difícil que falem quais adjetivos podem classificar alguém. Como os alunos não falam nada, o professor fica estressado. Aos poucos eles vão participando e o professor pega dicionários na biblioteca pra que eles procurem adjetivos e possam respondê-lo. $\mathrm{O}$ professor pede que eles procurem no dicionário o significado de: ingênuo, puro, inocente, entre outras. (Diário de campo - visita 11.1).

Em seguida, com base na comparação com as personalidades dos próprios alunos, o professor levantou perfis possíveis para um filme, dependendo do tipo de narrativa: comédia, drama, suspense. Talvez essa comparação tenha gerado confusão na compreensão, pois os alunos se ofereceram para fazer determinado tipo de personagem, comparando-se a ele:

O professor pede que eles escolham os nomes dos personagens que farão parte da história escolhida e escrevam a personalidade de cada um deles. Ele explica como são essas características e como elas podem ajudar na construção da história. Para isso, faz referência à personalidade dos alunos e diz que determinado personagem pode ser: esperto, medroso, engraçado, corajoso, aventureiro, etc. Dá os exemplos das características deles com situações possíveis dentro do roteiro que eles estão criando. Diz para eles pensarem agora, pois assim já podem usar na escrita. Ao que um aluno diz: "Eu posso ser o Paulo, corajoso!" - então, explica que não estão escolhendo quem fará os personagens agora, mas as características deles, pois as escolhas de quem fará o quê serão feitas depois: "Esqueçam quem vai fazer o quê agora, ninguém sabe quem vai fazer os personagens. A gente não está escrevendo o que vocês vão fazer. A gente está descrevendo os personagens." (Diário de campo - visita 8.1).

A proposta de caracterização dos personagens perdeu continuidade entre o início da escrita do roteiro e a escolha dos alunos para atuarem no filme. Muitos personagens foram criados durante a escrita do texto e não houve uma 
construção mais firme do perfil de cada um deles, pois essa parte do processo teve que ser suprimida pela urgência que demandava o início da escrita do roteiro. A atividade com os dicionários, abordando as definições de adjetivos para os personagens, não teve uma finalização. A discussão sobre as atitudes dos personagens com base em suas personalidades poderia ter ajudado para construção do roteiro, porém, conforme explicam Hobbs \& Moore (2014, p. 32), "quando o foco deve estar em um produto final, certas concessões podem reduzir as possibilidades dos alunos de explorar criatividade, espontaneidade, e experimentação em seu trabalho." 59

A falta de repertório sobre tipos de personagens e de vocabulário dos alunos pode ter contribuído para a dificuldade de compreensão do que o professor queria com essa atividade. Um diálogo com professores de língua portuguesa ou de sala de leitura para tratamento de tipos de personagens em suas aulas poderia ter contribuído com esse momento da oficina. O material didático do British Film Education (2010, p. 4) apresenta diversas maneiras de como um filme pode ser usado para tratar de assuntos de diversas disciplinas:

Você pode usar o filme para melhorar o aprendizado em todo o currículo, independentemente do seu nível de especialização. Ensinar em disciplinas de Inglês e Línguas Estrangeiras Modernas para Ciência e pode se beneficiar do uso de câmeras simples para gravação, anotações ou revisão, ou da exibição de clipes curtos para melhorar o entendimento das crianças sobre um tópico. ${ }^{60}$

Mais uma vez, a exibição de alguns trechos de filmes a que ele pudesse fazer referência nessas conversas fez falta, pois Jonas se referia a personagens bastante conhecidos da TV ou do cinema, e seus exemplos podiam não ser de conhecimento de todos os alunos.

\section{* Roteiro}

Antes de iniciar propriamente a escrita, o professor deu uma aula explanatória sobre as partes de um roteiro: cabeçalho (espaço e tempo), ação, personagem, diálogo, rubrica, transição, plano, dando exemplos no quadro mesmo. Em seguida, falou dos tipos de plano (aberto, detalhe, americano, entre outros), comentando cada um deles e desenhando na lousa, quando necessário.

\footnotetext{
59 Tradução minha do original: "[...] when the focus must be on na end product, certain concessions may reduce students' possibilities to explore creativity, spontaneity, and experimentation in their work."

60 Tradução minha do original: "You can use film to enhance learning across the curriculum, whatever your level of expertise. Teaching in subjects from English and Modern Foreign Languages to Science and PE can benefit from using simple cameras for recording, note-taking or reviewing, or from showing short clips to enhance children's understanding of a topic."
} 
Os alunos assistiram com bastante atenção e anotaram tudo o que estava escrito no quadro.

Depois, Jonas apresentou todas essas partes do roteiro no programa Celt ${ }^{61}$, em que os alunos deveriam digitar a história. Todas as aulas em que precisavam assistir a algum vídeo ou usar o programa, os alunos se sentavam ao redor de um computador com tela de 18'.

Em seguida, passaram à elaboração da escaleta do roteiro, dividindo as cenas e indicando em cada uma delas as situações, onde ocorriam, para assim saberem o tipo de locação, figurino, entre outras coisas. O professor começou a digitar essas informações no programa e os alunos logo aprenderam e passaram a digitar, incluindo número da cena, cabeçalho, espaço, tempo, entre outras. Enquanto eles resolviam o que colocar no texto, Jonas ficava em seu computador, mas sempre interferia, dando orientações para o roteiro:

Tudo tem que fazer sentido, tudo o que a gente escreve tem que se justificar de alguma maneira. A gente não pode escrever uma coisa que alguém depois vai assistir ao filme e vai falar: "Até parece que eles iam fazer isso! Não acredito." A gente tem que acreditar minimamente no que a gente está vendo. Senão, as pessoas não vão se identificar com o filme e não vão querer assistir se a gente não convencer que isso pode ser real. A gente tem que mostrar que isso pode ser uma situação real que poderia estar acontecendo com vocês de verdade. (Transcrição da aula - visita 8.1).

Por vezes, ele se aproximava do grupo frente ao computador e corrigia os erros de português no texto, ou ensinava "macetes" sobre como usar melhor o programa:

O professor "reclama" que os alunos não pensam na história como um todo, que eles estão no texto desde o início das aulas e não caminham no desenvolvimento do roteiro que ainda não tem falas. Os alunos começam a discutir, dizendo que um só fala e que os outros não ajudam. Fala que eles precisam se impor e colocar sua vontade nisso. Ele estranha que essa turma tenha sido a primeira a escolher a história que iria contar e até agora não tinha terminado de escrevê-la. Os alunos, então, passam a dar mais ideias para a escrita do texto no Celtx. Alguns acompanham os colegas, falando, mas bocejam com sono. O professor fala como eles poderiam desenvolver a cena final do filme, em que é descoberto que o homem não matou a colega deles e termina dizendo para os alunos escreverem: "Escrevam!" - e sai, deixando os alunos resolverem a história sozinhos. Os alunos conversam sobre as cenas que faltam escrever e reclamam que o computador está travando, com mouse com problemas desde o início da aula. (Diário de campo - visita 12.1).

61 Programa multiplataforma, com software livre, que pode ser usado para a pré-produção de projetos que podem ser: filmes ou programas de TV e séries, peças teatrais, quadrinhos e animações. As tarefas dividem-se em construção de roteiros, áudios, storyboards ou orçamentos de produções. Sua interface traz um processador de textos com layout dinâmico e diversas opções para a construção dos projetos. Como a produção é salva on-line, é possível compartilhar projetos com outros usuários do software. Disponível em: https://www.celtx.com. Acesso em: 9 abr. 2018. 
Jonas sempre mencionava nas aulas que queria terminar o roteiro antes das férias, para que os alunos voltassem às aulas no segundo semestre com suas falas decoradas e as filmagens ocorressem da melhor forma possível, mas isso não aconteceu. Embora conversasse com a turma e pressionasse os participantes para seguirem um cronograma, isso não ocorreu dessa maneira. $A$ escrita do roteiro demorou muito, sendo iniciada no final de maio e terminada apenas no início de julho, tomando dois meses. Em uma das aulas o professor comentou com o grupo que a oficina tinha por objetivo o trabalho de escrita, auxiliando na construção do pensamento, com intenção de simular uma experiência de construção de um filme. Portanto, desde o princípio deixou bem claro que o roteiro era uma parte importante da sua proposta.

A escrita do roteiro acontecia na hora em que os alunos sentavam para digitar o texto no programa. Embora o professor solicitasse que eles pensassem em casa sobre as falas e os acontecimentos do filme, a turma deixava para resolver tudo apenas na hora da aula. Com a demora na finalização da escrita, o professor demonstrava descontentamento com a falta de compromisso dos alunos com a oficina e sempre reclamava disso com eles no início das aulas, ao perceber que o roteiro não estava terminado. Cobrava dos alunos que entrassem no Celtx em casa, se cadastrassem e continuassem a escrever, sem aguardar o dia da oficina, mas isso não aconteceu.

Ao questioná-lo sobre seu embasamento teórico para a elaboração da oficina, tendo como principal base a escrita do roteiro, ele respondeu:

Então, durante um tempo, assim, eu procurei seguir, é... Não como... Seguir fielmente, né? Mas eu me baseei muito em roteiristas que têm livros publicados, enfim, eu pegava algumas ideias de desenvolvimento de roteiro de alguns roteiristas e usava, de repente, o livro como base. O Syd Field foi um que eu usei uma época... Então, assim, durante um bom tempo eu tentava, partindo das ideias que ele desenvolvia, trabalhar isso. Depois, eu fui conhecendo outros e fui pegando uma coisa de um, uma coisa de outro, e tentando transformar para a minha realidade, porque a grande maioria das vezes - principalmente dentro dessa parte de criação de roteiro, que era uma coisa que eu, por não ter formação na área, sentia mais dificuldade, assim, de me apropriar dessas informações... Era onde eu buscava mais informações. Então, assim, fui buscar A jornada do escritor lá... Buscar alguns livros que achava que eu poderia em determinado momento contribuir pra minha formação pra que eu pudesse repassar. Mas aí, depois de um tempo, eu fui introduzindo coisas que eu ia descobrindo e fui adaptando pras minhas descobertas. Então, assim, hoje eu não sigo nada especificamente teórico, uso um pouco de cada coisa, mas como são realidades muito diferentes e eu não consigo visualizar, assim, uma bibliografia ou uma... Sei lá, uma referência de um trabalho parecido com o que eu faço, com que eu possa me espelhar, assim, eu acabo não seguindo nada teórico. Então... Eu sinto falta, inclusive, disso, assim, de referências de outros trabalhos que sejam mais próximos da realidade que eu tenho, assim. Acho que isso é uma carência que a gente tem. (Professor Jonas). 
Ele reafirma nessa fala seu interesse por levar os alunos a produzir um roteiro bem construído, tanto que buscou estudar sobre essa parte específica do trabalho de produção audiovisual. Ao ser questionado sobre os resultados que ele esperava dessa oficina, afirmou que buscava:

[...] dar a oportunidade desse aluno se expressar de uma maneira artística, ou não, assim... Mas de se expressar com suas ideias, colocar suas ideias no papel para que ele possa estimular novas possibilidades que talvez ele não tenha no dia a dia, a não ser numa aula de português em que ele vai fazer uma redação. (Professor Jonas).

Essa fala deixa claro que o professor percebe a possibilidade de expressão dos estudantes por meio da escrita, ao indicar que a oficina Ihes daria oportunidade de se expressar, ao "colocar suas ideias no papel"62. Essa impressão é confirmada quando ele diz que as únicas possibilidades que os estudantes têm para se expressar na escola é através das redações feitas nas aulas de português.

Em uma das aulas em que a turma se mostrou desestimulada com a escrita do roteiro, o professor explicou porque estavam dando tanta atenção a essa parte do filme:

É um trabalho de construção coletiva, onde cada um vai contribuir de alguma maneira pra que a gente escreva o roteiro e depois transforme isso num filme. Essa é a ideia da oficina de cinema. Faz parte do projeto da oficina de cinema, escrever. Um dos objetivos dessa aula é estimular a escrita porque a reclamação de muitos professores é de que os alunos não escrevem bem porque leem pouco. Então, vamos estimular a escrita. Fazer com que você tire uma ideia na cabeça e coloque no papel é um exercício em que você vai trabalhar sua escrita, organizar seu pensamento. [...] Então, pra quem tá chegando agora e pra quem não sabe, o objetivo da aula é passar por um processo que simula - porque não é um processo real - que simula a produção de um filme. Pensando desde o roteiro, onde a gente escreve um roteiro, passando por todas as diversas etapas de gravação, direção, experimentando as diferentes funções [...]. (Diário de campo visita 6).

A falta de celeridade no processo de escrita dos roteiros de todas as turmas foi o elemento chave para muitas discussões em sala entre o professor e a turma: enquanto ele pedia maior participação de todos para a construção de uma parte primordial para o filme, conforme sua visão, os alunos faltavam, negligenciavam a escrita em casa, burlavam o combinado nas aulas, participavam pouco desses momentos, chegando a desistirem da oficina.

A proposta teórico-metodológica que ancora a oficina de vídeo dá o tom para a força de cada elemento trabalhado durante o processo. Há autores que consideram o roteiro uma parte importante da produção, porém, como apenas

${ }^{62}$ Ao término do trabalho de campo, vi no Facebook de Jonas que ele publicaria um livro sobre criação de roteiro em oficinas de vídeo na escola. 
mais uma etapa, ou seja, como algo que necessita ser feito para guiar os próximos passos a serem seguidos, sem que seja preciso ser tão rígido em relação à construção dessa escrita.

$O$ roteiro se mostra, assim, como um guia, um pano de fundo para o processo que se desenrola no decorrer das filmagens. Além disso, nem sempre é possível seguir exatamente o que foi proposto ali, pois as condições e ideias mudam no decorrer do processo. Na oficina observada, foi preciso descartar partes do texto por conta da falta dos alunos e pelo pouco tempo para finalizar as gravações. Pimentel (2013, p. 124) relata situação parecida, destacando como os usos do roteiro precisam estar a serviço das condições e intenções da produção de vídeos na escola:

$\mathrm{Na}$ finalização do vídeo, percebemos que o Roteiro Técnico foi um grande instrumento que nos deu a direção do que fazer, de como gravar. Mas, na prática, o percurso foi marcado por várias alterações de rota em todas as sequências, bem como nos diálogos, músicas, técnicas de enquadramentos e movimentações de câmera. No realizar do trabalho fomos refletindo sobre ele e, muitas vezes, achando outras maneiras de produzir a cena de forma mais simples, mais lógica e também mais emocionante. Nada praticamente, após a edição, ficou de total conformidade com o planejado no roteiro técnico.

Alguns pesquisadores relatam a dificuldade que encontram em criar um roteiro coletivamente nos projetos de cinema em contextos educativos, pois há muitas ideias e a disputa por elas pode gerar conflitos a serem mediados pelo professor. Nakache $(2011$, p. 74$)$ indica a dificuldade desse processo:

[...] o trabalho para a escrita de uma boa história original implica uma tarefa muito difícil por parte de crianças e jovens, o que se soma àquela de representar essa história à maneira do cinema. Portanto, diante da oportunidade de uma oficina de cinema semestral, escolhe-se priorizar a segunda, a fim de transformar toda a energia criativa em imaginar como contar essa história conhecida em uma tela. ${ }^{63}$

Pires (2014, p. 106) conta sua experiência com os jovens, buscando justificar a dificuldade em trabalhar com a escrita:

Constatamos que na escola tínhamos dificuldades na elaboração de roteiros por parte dos alunos, isso porque escrever para eles, por vezes, parecia um martírio. Por mais que tentássemos explicar a importância da escrita na vida moderna, da necessidade de saberem se expressar e dominar as normas ortográficas e as regras básicas para uma boa redação de texto, eles "se amarravam" e produziam o mínimo que podiam. Quando o trabalho proposto era para ser feito em grupo, o desempenho era melhor porque alguém do grupo assumia essa função e outros se envolviam na parte da criação, dando dicas para história, cenário, locações, figurino, o argumento do roteiro.

63 Tradução minha do original: "[...] el trabajo para la escritura de un buen relato original implica una labor muy difícil por parte de niños y jóvenes, que se suma a la de representar esa historia a la manera del cine. Por ello, ante la oportunidad de un taller semestral de cine, eligió priorizarse la segunda, de modo de volcar toda la energía creativa en imaginar cómo contar esa historia conocida en una pantalla." 
Essa observação da autora levanta a importância que a cultura do escrito tem nas propostas criativas dentro da escola. As crianças e jovens de hoje, considerados como "espectadores plenos" (Norton, 2013), comunicam-se e transitam em uma cultura amplamente imagética. Por que continuamos a pensar a produção audiovisual a partir da escrita e não de exercícios com imagens, como propõem Fresquet $(2013,2014)$, Migliorin et al. (2016), Olmeczuck (2016) e Berti (2016)? Experimentar imagens e sons além de ser mais atraente para os jovens que chegam às oficinas bastante interessados em manipular um equipamento ou um programa de edição do que em escrever, pode ser mais adequado à aprendizagem da linguagem audiovisual. No contexto observado, desde o início da oficina até a finalização do roteiro, não houve nenhuma atividade de experimentação de imagens.

Em algumas oficinas, a escrita do roteiro é simplificada pelo tipo de filme a criar, optando-se, por exemplo, pela realização de entrevistas jornalísticas (Costa, 2014; Costa Oliveira, 2011; Oliveira, 2015; Sato, 2015). Há experiências em que os professores/pesquisadores produzem o roteiro, a fim de aproveitar o tempo para que os alunos filmem e editem o vídeo (Faria, 2011; Hobbs \& Moore, 2014; Saldanha, 2016). Husbye (2013) relata a dificuldade que os alunos tiveram ao escrever o roteiro que foi finalizado por ele para darem início às gravações. Talvez esse processo seja mais difícil porque se trata de um novo gênero textual que os alunos ainda não dominam e, portanto, necessitaria de uma abordagem mais amiúde, o que nem sempre é possível pela falta de tempo, como relata Toledo (2014, p. 145):

O processo de ensino sobre como escrever roteiros é muito simplificado em uma oficina. Fala-se pouco de atos, pontos de virada ou outros aspectos avançados. Fala-se de personagem, de conflito, de temáticas e de formas de abordagem documental. Mais do que introduzir teorias, é nessa etapa que se busca auxiliar os estudantes a irem além dos formatos de novela, filmes norte-americanos ou do Globo Repórter. Quanto mais novas as formas de linguagem propostas e discutidas pelos professores, maiores as chances de que os estudantes consigam propor ideias em que temática e forma, o assunto e o meio de representá-lo, consigam integrar-se em obras audiovisuais completas e complexas.

$\mathrm{Na}$ oficina observada, houve uma aula sobre roteiro, abordando algumas partes que constituem esse texto. A aula foi explanatória e os alunos participaram copiando o que era anotado no quadro pelo professor. A meu ver, se o objetivo é trabalhar a escrita dos alunos a partir dessa atividade, seria importante adotar uma abordagem mais focada na construção textual, contando inclusive com escritas dirigidas e avaliadas em grupo para aprendizagem e domínio da escrita, antes de passarem para a construção da história que seria 
filmada. Pimentel (2013, p. 116-117) relata que isso pode ser feito de forma abreviada, em busca de uma definição mais elaborada daquilo que os alunos querem contar:

[...] os alunos se mostraram motivados ao planejamento do nosso próprio vídeo, mas abreviaram as etapas e, ao final, havíamos produzido quatro peças de descrição da história: storyline, sinopse, fragmentos de um roteiro e, finalmente, o Roteiro Técnico. No diálogo de fomento sobre o que escrever, vários aspectos foram debatidos: De que trataria o vídeo? Quem e como seriam as personagens? Nosso vídeo teria um protagonista e antagonista? Haveria um vilão ou vilã? Como e quando seria a catarse da história? Que mensagens gostaríamos que o vídeo deixasse para os jovens? Qual o nome do vídeo? Assim, começamos a construir a trama.

O roteiro final da turma que concluiu a oficina conta a história de uma garota que desconfia que seu namorado a está traindo com uma colega de turma, mas na verdade ele está organizando uma festa de aniversário surpresa para ela junto com seus colegas. Essa história lembra alguns enredos repetidamente abordados em séries juvenis, como Malhação, por exemplo. Trata-se de um tema próximo da idade dos alunos, em que começam a namorar e a experimentar questões como ciúme, conforme abordam no roteiro.

\section{* Abordagem da linguagem audiovisual}

O aprendizado com imagens exige também revoluções formais. Não chegaremos, por exemplo, a produzir filmes e vídeos de aprendizagem que mereçam este nome se não nos inserirmos na própria história das imagens em movimento, procurando no cinema, que veio bem antes do vídeo, lições de imagem e de som. (Leandro, 2001, p. 32).

Com o roteiro pronto, o professor deu uma aula sobre sintaxe da narrativa cinematográfica, com um vídeo editado por ele mesmo, contendo cenas dele e do vídeo "Por trás da cena", da Multirio64. De acordo com Kearney \& Schuck (2005), antes de passar às filmagens, é preciso que os alunos desenvolvam algumas habilidades de criação de filmes e um entendimento básico da

\footnotetext{
64 "Empresa Municipal de Multimeios, vinculada à Secretaria Municipal de Educação da Prefeitura da cidade do Rio de Janeiro [que] utiliza-se de uma plataforma digital na qual as diferentes mídias - TV (canal 26 da NET), redes sociais (Facebook, Youtube, Twitter e Instagram), Web Rádio, Portal, pen card e impressa - interagem, diversificando as possibilidades de acesso aos seus produtos e oferecendo à escola pública da cidade do Rio e à população em geral, em tempo real, o que há de mais atual em produções e interfaces educativas." (Disponível em: http://www.multirio.rj.gov.br/index.php/multirio/a-multirio. Acesso em: 24 jan. 2019).
} 
linguagem da mídia em questão para que a tecnologia seja perfeitamente integrada ao processo de aprendizagem.

O ensino-aprendizagem da linguagem cinematográfica, contraditoriamente, não parece ser um tema recorrente nas oficinas de cinema relatadas em pesquisas sobre cinema na escola. Muitas vezes, os alunos já partem para a filmagem sem nenhum contato com os elementos da linguagem audiovisual. Quando abordam tais questões, alguns projetos resumem-se a uma aula sobre gêneros narrativos possíveis (documentário, ficção, animação, etc.), com maior foco naqueles que vão abordar na oficina (Menezes, Adrião \& Rios, 2017; Oliveira, 2011; Saldanha, 2016); dificilmente promovem exercícios de posicionamento e movimentação de câmera, escolha de ângulos, captação de som para que os estudantes possam não apenas manusear os equipamentos, mas experimentar formas de contar usando imagem e som. A maior parte dos projetos de produção audiovisual na escola apresenta aulas expositivas para abordar a linguagem audiovisual (Faria, 2011; Costa Oliveira, 2011). Porém, muitas dessas abordagens ocorrem durante a visualização de filmes, antes do início das filmagens. Algumas oficinas tratam desse tema no desenrolar da produção, como relata Toledo (2010, p. 174):

\begin{abstract}
Apesar do grande fascínio que a câmera exerce sobre os alunos, essa aula em geral não ocorre nos primeiros dias de oficina, mas, muitas vezes, em um momento no qual as equipes, já definidas, estão começando a preparar seus vídeos. Sendo assim, não é incomum que tais atividades acabem sendo ministradas apenas para alunos realmente interessados em exercitar tais funções durante a gravação - 0 que se por um lado afasta o restante da equipe dos reais desafios envolvidos no trabalho da equipe técnica, por outro, permite um maior aprofundamento para os que participam da atividade.
\end{abstract}

$\mathrm{Na}$ oficina observada neste estudo, essa aula aconteceu em um dia do mês de setembro, quando as turmas já estavam definidas, e foi apresentada para todos os envolvidos. Nesse período, a oficina contava com apenas uma turma de nove alunos que permaneceram até o final do ano. Concordo com Toledo (2010) que nem todos os alunos se interessem pelo tema, mas se levarmos em conta a importância da alfabetização audiovisual de jovens e crianças, esta se mostra uma boa oportunidade de apresentar a eles como se constroem narrativas desse tipo. Durante essa aula, apenas um dos alunos, Leo, participou e respondeu com bastante entusiasmo as perguntas do professor, trazendo conceitos que estruturam essa linguagem para aulas posteriores, o que indica que ele aproveitou bastante a explanação feita pelo professor. 
Embora estivessem assistindo à explicação, os alunos não participaram da aula, e, portanto, é impossível saber o que estavam aprendendo com o vídeo e com a conversa que o professor estabeleceu com Leo. O maior interesse desse aluno nessa aula especificamente pode estar relacionado ao curso de edição de vídeo que ele faz fora da escola. Trata-se de um tema que ele parece ter certo domínio, pois os termos não são novos para ele e a aula se desenvolveu como um momento em que ele aproveitou para tirar dúvidas sobre alguns conceitos ou para demonstrar com exemplos de que sabia do que o professor estava falando.

Pode-se supor que o fato de a maioria dos projetos de produção audiovisual na escola não abordar diretamente o estudo e o domínio da linguagem audiovisual em suas atividades se deve à falta de conhecimento dos professores sobre o assunto. De um modo geral, quem oferece essas oficinas nas escolas nem sempre tem formação nessa área e dificilmente pode contar com assessoria de um expert para abordar o tema de forma adequada e prefere não se arriscar a fazê-lo. Por isso, grande parte das propostas de produção de vídeos na escola se restringe à criação de "documentários" com entrevistas ou a narrativas com câmera fixa (Costa, 2014; Costa Oliveira, 2011; Oliveira, 2015; Sato, 2015), acarretando menos "trabalho" para a edição das imagens em momento posterior. Os vídeos produzidos na escola observada ousaram pouco em posicionamento de câmera; as filmagens feitas durante a oficina observada foram com câmera na mão ou no tripé, bem próximas aos personagens, priorizando planos abertos na rua, em sala, ou no pátio. As vezes em que foram usados movimentos de câmera ocorreram nas cenas em que os personagens andavam na rua, com a câmera sempre à frente de quem estava caminhando.
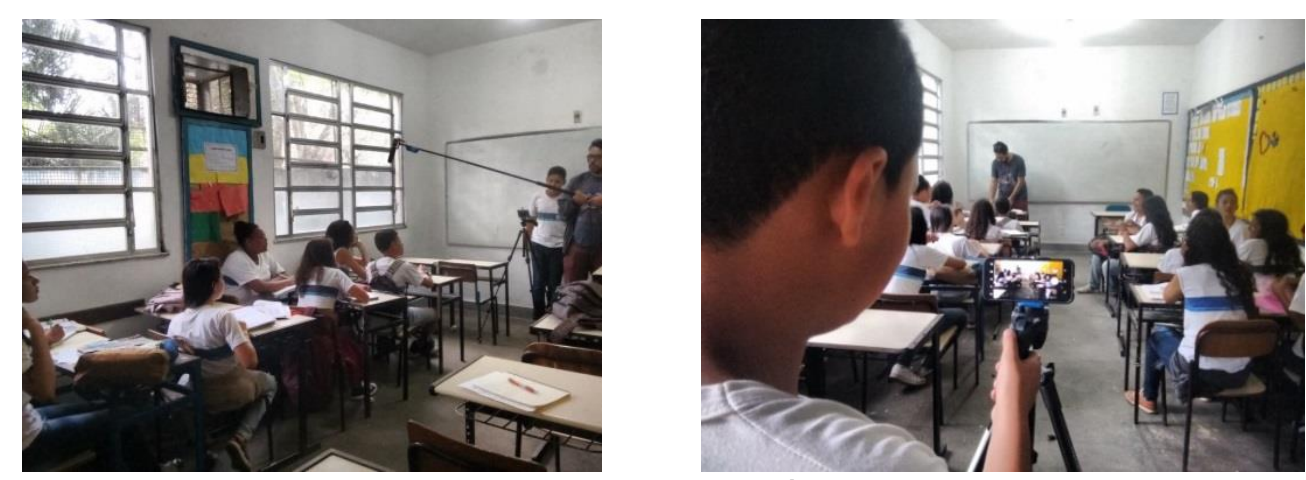

Figura 19 - Montagem com disposições da câmera durante as filmagens Fonte: Arquivos da pesquisa.

A proposta teórico-prática da vertente de cinema-educação tem uma abordagem mais abrangente da linguagem cinematográfica, uma vez que essa perspectiva propõe olhar o mundo em uma relação mediada pela câmera. 
Fresquet (2014, p. 73) indica dez critérios entendidos como "gestos fundadores no trabalho de iniciação com o cinema", considerados pela autora como "gestos cinematográficos de escolha, disposição e ataque", a partir da proposta de Bergala:

1ํ. Enquadrar; $2^{\circ}$ Fazer de conta e tomar decisões; $3^{\circ}$ Ensaiar modos de ver: construir pontos de vista; $4^{\circ}$ Ensaiar modos de ouvir: construir pontos de escuta; 5o Ocultar/revelar; 6을 Colocar em relação; $7^{\circ}$ Crer/duvidar; 8 "Descronologizar" e intensificar o tempo; 9을 Inventar; $10^{\circ}$ Criar sentidos.

Trata-se, assim, de uma proposta de realização de diversas experimentações com imagens e sons, mediadas pela câmera e pelos filmes que são vistos em paralelo às criações de imagens que, por sua vez, são vistas e comentadas após as filmagens. Ao tratar do ensaio de "modos de ver", por exemplo, a autora aborda a construção do ponto de vista:

Consiste em identificar que construímos um ponto de vista em boa parte pela intencionalidade do filme e de todos os elementos psicológicos, estéticos, históricos e de linguagem que foram escolhidos para configurar um determinado modo de ver do espectador. [...] a construção do ponto de vista se constitui entre o nosso modo de ver, que recorta a percepção a partir de necessidades, de desejos, de memórias, de afetos, de condição sociopolítica, etc., e o filme como produto das intenções concebidas na sua criação, impressas na combinação de diferentes possibilidades da linguagem. (Fresquet, 2014, p. 75).

Essa pedagogia audiovisual propõe que se fuja do que está pronto e de modelos determinados. Ao apresentar aos estudantes cenas e pontos de vista clássicos do cinema, por exemplo, instiga-os a construir seus próprios pontos de vista através de experimentações de ângulos, sons e modos de mostrar/ocultar/revelar no cinema ${ }^{65}$.

\section{* Divisão de papéis}

O momento seguinte da oficina foi a divisão das tarefas de cada um nas gravações, incluindo quem faria os personagens do filme. Com o roteiro pronto, já se sabia que a história tinha dois personagens principais (um casal), quatro personagens secundários (amigos do casal e professor) e figurantes. A turma entrou em consenso sobre os papéis principais, mas resolveram fazer testes para o papel da melhor amiga da personagem principal, pois havia quatro meninas para ele. Mais uma vez a oficina simulou a criação de um filme, pois mesmo havendo poucas pessoas para fazer a personagem, eles pensaram em um teste, como ocorre na indústria audiovisual. Para Hobbs \& Moore (2014, p.

\footnotetext{
65 Fresquet (2014) apresenta uma lista de 20 exercícios dessa pedagogia.
} 
31), simular a produção de um filme e, portanto, a divisão de tarefas não é um problema, uma vez que os jovens se apropriam dessa cultura, tão difundida pela mídia:

Assim como os estudantes imitam a mídia que lhes é mais familiar particularmente as narrativas cinematográficas e televisivas de ficção -, os profissionais e os educadores artísticos podem estimular a imitação da estrutura hierárquica dos papéis de produção. ${ }^{66}$

O professor resolveu filmar o teste organizado pelos alunos, que escolheram uma cena para as candidatas ensaiarem e gravarem. Cada teste foi filmado para depois eles assistirem e escolherem juntos quem faria esse papel. Nesse dia, eles filmaram com uma câmera profissional e microfone de vara, já ensaiando como seriam as gravações oficiais do filme. Leo estava à frente do ensaio, atuando como diretor.

Nessa atividade, o professor ficou atrás da câmera, ensinando os garotos a manusearem o gravador de som, o microfone e a câmera. Enquanto isso, as alunas ensaiavam as cenas. O professor ensinou Leo a dirigir a cena, a anunciála após conferir som e câmera, e a simular o som da claquete com as mãos. Ele chegou a mostrar um aplicativo em seu celular que serve de claquete, mas não o usou nas filmagens com a turma. Rapidamente, os alunos sabiam o que dizer e fazer antes de gravarem. Essa aula serviu como um grande ensaio de como seriam as filmagens valendo, pois além da escolha das personagens, os alunos experimentaram os equipamentos necessários para as gravações.

Ainda nesse mesmo encontro, o professor deu uma aula sobre o uso e cuidado necessário com os equipamentos, ressaltando que estes são muito caros e o manuseio errado pode causar grandes prejuízos. Para ilustrar isso, contou experiências anteriores em que outros alunos quebraram tripés e câmeras e ele precisou gastar muito dinheiro para recuperá-los ou comprar outros. Apresentou cada um dos equipamentos para os alunos, dizendo como devem usar o gravador, a câmera e de que maneira as ordens do diretor devem ser seguidas para o início e término da gravação de cada cena. Durante essa explicação, havia apenas alguns alunos por perto, observando o que Jonas estava explicando, enquanto outros garotos e as garotas da turma ensaiavam para o teste. Portanto, essa explicação não foi dada para toda a turma. Após os

66 Tradução minha do original: "Just as students imitate media that is most familiar to them particularly the narrative tropes of fiction film and television - professionals and artisteducators may encourage imitation of the hierarchical structure of production roles." 
testes, os alunos assistiram aos vídeos no computador do professor e escolheram coletivamente quem faria a personagem.

A divisão de tarefas para a filmagem (direção, personagens, câmera, som, etc.) também aconteceu durante esse teste, mas não foi indicado exatamente quem faria o quê, a não ser a direção, que seria feita por Leo. Durante as gravações, dois alunos se revezaram no manuseio do microfone e na gravação de som, mas no decorrer das gravações, esses postos precisavam ser ocupados por outros alunos, pois eles faltavam. Por fim, o professor passou a filmar, gravar áudio e até segurar o microfone, pois "precisava terminar o filme", como mencionou, posteriormente, na entrevista. Por não terem sido distribuídas as tarefas de cada um, designando suas atribuições, nunca se sabia ao certo quem faria o quê em cada dia de filmagem; isso era agravado pela turma ter que contar com quem estava presente. A escolha dos alunos que fariam os personagens do filme foi a única atividade de organização da oficina de que todos participaram.

Em dado momento, o professor passa a câmera para Marcio que até então estava
à parte das atividades. Ele se interessa e participa, envolvendo-se com a tarefa.
Às 10 h30 chega Leo, diretor do filme, dizendo ter esquecido que a oficina havia
sido marcada para 9 h. No início, ele fica um pouco deslocado sobre o que estão
fazendo. Depois, pega o roteiro e se inteira da cena que estão filmando. [...] Em
seguida, eles filmam 3 tomadas abertas e 2 fechadas da cena de entrada no pátio
da escola. Os demais alunos se revezam na tarefa de segurar o microfone de
vara. Nessas primeiras filmagens, Tobias está com o captador de som e os fones,
Marcio filma no celular com o professor, Igor segura o microfone de vara e os
demais são atores. [...] Os alunos saem para gravar a cena no pátio da frente da
escola. Nessa cena, mudam de posições na filmagem: Leandra fica com o
microfone, Carla com o gravador de som e Leo filma com orientação do professor.
Os outros alunos presentes participam da cena: Tobias, Igor, João e Vanir. (Diário
de campo - visita 18).

Depois eles filmam a mesma cena mais uma vez, agora em plano aberto. Nessa tomada, Leo faz a câmera, pois o professor está participando da cena como professor da turma. Eles fazem uma tomada. (Diário de campo - visita 19).

Essa mudança de papéis durante as filmagens ocorria também com os alunos que atuavam no filme, pois houve a saída de uma aluna da escola durante as filmagens e eles precisaram modificar o roteiro e refilmar as cenas de que ela participava.

Hoje, Carla, que faria a amiga da personagem principal, substituindo Leandra, que saiu da escola, faltou. Sendo assim, eles mudaram toda a cena para conseguirem mudar os personagens e gravar com quem estava presente. Depois de resolverem isso, saem pra gravar. [...] $O$ professor reclama da falta de continuidade e de pessoas na equipe, o que atrapalha as filmagens e vai atrapalhar na edição. (Diário de campo - visita 22). 
A falta de organização dos papéis na produção do filme pode ser justificada por haver poucos alunos participando e pelo fato deles faltarem muito.

O professor lembra aos alunos como era essa cena, explicando como gravaram antes. Eles repassam o texto com a Vanir, que faz a personagem principal, lendo o roteiro e explicando aos demais como foi gravado. Sueli faz as falas da personagem Amanda. Nesse momento, o Vítor chama atenção de Sueli por ela falar muito baixo. O professor explica que ela precisa falar alto e insiste que é preciso. O professor manda Vítor sentar e fazer parte da cena, ficando ele próprio controlando câmera e microfone lá da frente. Então, refilmam a cena de vários ângulos. [...] Em outro momento, quem filma é Leo, direcionado pelo professor que também orienta Marcio com o microfone; Tobias fica com o gravador. Durante todas as filmagens, o microfone e o gravador ficam sob a responsabilidade de várias pessoas diferentes. (Diário de campo - visita 18).

Em outras pesquisas que analisam a produção audiovisual na escola, a divisão de tarefas, relacionadas às diversas fases do processo, é registrada como algo que ocorre de forma "orgânica", seguindo as características pessoais dos envolvidos. Para isso, é necessário que o grupo seja compreendido em suas características individuais, como indicam Hobbs \& Moore (2014, p. 31):

[...] o design do ambiente de aprendizagem envolve necessariamente a atribuição de papéis como uma característica estrutural fundamental da pedagogia. Os indivíduos são atribuídos a papéis e contribuem para a produção em relação às suas atribuições. Alguns são escritores; alguns são operadores de câmera; alguns são talentos, etc. Essa abordagem exige habilidades de criatividade e gerenciamento de tempo para garantir que os alunos sejam mantidos envolvidos no processo de pré-produção, produção e pós-produção. ${ }^{67}$

Direcionando a capacidade do cinema quanto à sua dimensão afetiva, Toledo (2014) considera que diversas competências entram em jogo nas atividades que envolvem várias pessoas em uma só produção:

Uma oficina também possibilita incluir e estimular diferentes tipos de inteligência. Em uma equipe de cinema tem-se o roteirista, o fotógrafo, o câmera, o ator, o músico, tem de um tudo. [...] há espaço para diferentes perfis psicológicos. O tímido e que tem grande inteligência de linguagem, poderá escrever o roteiro, ajudar a pensar o filme. $O$ aluno expansivo ou que gosta de planilhas poderá ser o produtor; o outro expansivo, que fala bastante, que demonstra capacidade para perceber variados pontos de vista, poderá ser o diretor. $O$ aluno que é mais visual ou tem facilidade com matemática, com ciências, pode de aproximar da fotografia ou da cenografia. Quem gosta de música, poderá fazer o som ou a trilha sonora. Quem é corporal, aquele aluno que só joga futebol, que não gosta de nada, pode adorar segurar o boom, ser o câmera, fazer o "corre", ser o platô, ou seja, fazer toda essa parte mais dinâmica do filme. (p. 151-152).

\footnotetext{
67 Tradução minha do original: "[...] the design of the learning environment necessarily involves the assignment of roles as a key structural feature of the pedagogy. Individuals are assigned to roles and contribute to the production in relation to their assignments. Some are writers; some are câmera operators; some are talent, etc. This approach requires creativity and time management skills to ensure that learners are kept engaged across the pre-production, production, and postproduction process."
} 
A possibilidade de criação coletiva é o que mais chama atenção em projetos desse tipo, pois oportuniza aos alunos a interação social e criação de um vídeo desde sua concepção. Fresquet (2013) enxerga nesse momento uma possibilidade de colocar em jogo aspectos individuais e coletivos, porém, instiganos a ir além da obviedade de alunos desinibidos atuarem na frente das câmeras, enquanto os tímidos se responsabilizam pela filmagem, por exemplo:

A descoberta de novos interesses e capacidades pode contribuir para uma reconfiguração da autoestima de alguns estudantes, o modo como eles são vistos pelos professores e colegas e, inclusive, pelas próprias famílias. Desconstruir "papéis favoritos" que respondam ás características de personalidade já conhecidas pelo grupo pode significar perder a chance de um estudante tímido se revelar um grande ator ou diretor, por exemplo, assim como um líder nato, de ter que assumir para si o lugar de silêncio e da espera obrigada na vez do outro. ( $p$. $61)$.

A autora coloca em questão clichês presentes na prática de fazer cinema na escola. É muito mais fácil pensar que não será preciso preparar alunos para os personagens principais, pois o grupinho de alunos extrovertidos já está pronto para isso. Ousar outras possibilidades de fazer cinema na escola dá trabalho e necessita de tempo e observação por parte dos professores para compreender a turma, seus dilemas e aquilo que pode ser transformador para o grupo. Para essa experimentação de papéis, Fresquet (2013) propõe uma rotatividade dos estudantes nas diferentes funções nas fases de pré/per/pós-produção do filme, ressaltando que:

[...] a criação cinematográfica no contexto escolar teria seu potencial pedagógico comprometido se o líder da turma se tornasse sempre o diretor, a aluna considerada mais linda atuasse como protagonista, e os tímidos evitassem toda exposição. O deslocamento dos sujeitos é algo central na proposta de Bergala, perpassando o desafio indivisual e coletivo no fazer cinema. (p. 61).

Alguns alunos da oficina observada mudavam suas funções no decorrer das gravações pela necessidade de alguém ficar responsável por determinada tarefa, uma vez que os alunos sempre faltavam. Mas os alunos escolhidos para direção e para atuação dos personagens principais eram sempre os mesmos. Não parecia haver uma preocupação especial, por parte do professor, em acompanhar de perto a evolução de cada aluno nas tarefas pelas quais estavam responsáveis. As atenções de todos estavam voltadas à finalização das gravações. Não houve a indicação de alunos que ficassem responsáveis pela produção, figurino, maquiagem e cenário, sendo tudo isso resolvido coletivamente, seguindo as indicações do professor sobre as decisões a serem tomadas. Duas alunas atuaram como figurantes em toda a gravação e pouco se 
envolveram com questões técnicas. No final da oficina, uma delas comentou comigo que gostaria de ter feito alguma personagem:

Keyla e Sueli continuaram observando as filmagens de longe, onde eu estava. Keyla comentou comigo que era ruim ela não ter papel no filme, que só tinha pra duas meninas que já estavam filmando. Eu comentei que ela deveria ter se oferecido e ela respondeu que foram os meninos que escolheram quem faria os personagens e não a escolheram. (Diário de campo - visita 23).

Keyla chegou a fazer testes para o papel da amiga da personagem principal, mas, como disse, não foi escolhida. Ela é uma aluna um tanto fora dos padrões estéticos estabelecidos socialmente, é mais alta que os demais e "gordinha" e, talvez isso tenha interferido para que não fosse a opção mais interessante, na visão da turma, para o papel. É interessante notar que ela estava sempre se escondendo da câmera, não gostava que eu tirasse fotos suas para a pesquisa, mas no final da oficina demonstrou estar chateada por não ter sido uma personagem do vídeo. A aluna escolhida para fazer essa personagem faltava sempre às aulas e o professor chegou a colocar Sueli no lugar dela, porém, não ficou satisfeito com a atuação dela, porque falava muito baixo. Em nenhum momento foi cogitada a possibilidade de colocar Keyla no papel da amiga, o que poderia resolver a demora nas filmagens, pois ela nunca faltava $e$ estava sempre disposta a ajudar. Esse talvez fosse um momento importante para discutir estereótipos nos modos de representação adotados pelas produções audiovisuais.

Por que a personagem principal tem que ser magra e bonita? Por que o diretor tem que ser o que se comunica melhor? Machado (2017) relata como foi desafiador o papel de diretor para um aluno tímido na produção de vídeo de sua pesquisa; esse aluno atuou como diretor junto de um colega mais extrovertido que, no início, funcionou como um mediador entre ele e a turma. Depois de alguns dias de filmagem, o aluno tímido passou a ter outra postura e a se colocar mais perante a turma. Um outro olhar pode ser exercitado também no momento de dividir tarefas na criação do filme na escola, como indica Fresquet (2013). Como se trata de uma "simulação" do processo de criação de um filme, não é preciso seguir um modelo fechado para ter sucesso no produto final.

\section{* Filmagens}

As filmagens começaram somente no dia 17 de outubro e foram realizadas em cinco encontros, sendo o último no dia 5 de dezembro. O grupo deveria ter oito encontros para essa parte do processo, mas em alguns dias, os alunos que 
faziam os papéis principais, sem os quais não era possível filmar, pois estavam em todas as cenas, faltavam aula e a oficina era cancelada. Sempre que os alunos eram liberados pela falta dos colegas, o professor conversava com os presentes sobre a importância da frequência de todos, do compromisso e de como era preciso que eles investissem nesse projeto. $O$ tom da fala denotava tensão e os alunos ficavam sempre em silêncio.

Desses cinco dias de filmagens, quatro ocorreram na escola (dentro da sala de aula, no pátio e nas ruas do entorno) e um na casa de uma das alunas. Percebi que os alunos atuaram com maior motivação apenas no primeiro e no último dia de gravações. O primeiro dia havia muitas novidades em relação aos equipamentos e à situação de aula, pois as gravações foram realizadas na rua, em frente à escola. Naquele momento, após 6 meses do início da oficina, os alunos estavam experimentando pela primeira vez a filmagem do que haviam planejado, portanto, era de se esperar maior envolvimento e ânimo de todos os participantes. No último dia de gravações, as tarefas foram melhor divididas. $\mathrm{Na}$ aula antes desse encontro, os alunos decidiram o que cada um traria para a festa que seria filmada e encerraria a oficina. Nesse dia, eles se dividiram em equipe de filmagem e equipe de produção. Enquanto o professor finalizava as filmagens com uma parte da turma, os demais organizaram as comidas na mesa da festa e o local onde seria filmada a cena final. Esse foi um trabalho em grupo sem o comando do professor, confirmando o que indicam Kearney \& Schuck (2005) sobre a forte motivação dos alunos em tarefas de própria autoria, nas quais estão mais livres do que aquelas designadas pelos professores.

Embora tenha faltado a alguns encontros, por conta de viagens e de trabalhos em outro local, no decorrer da oficina, o professor esteve presente na maior parte dos encontros. Os alunos, por sua vez, revezavam-se e ajudavam no que era necessário, atendendo às solicitações do professor. Para as gravações, o professor trouxe seus equipamentos de casa: filmadora, gravador, tripé, microfone de vara, fones de ouvido e notebook. Descrevo o primeiro dia de filmagem para apresentar essa etapa importante da metodologia do professor.

No primeiro dia de gravação, enquanto o professor imprimia os roteiros, alguns alunos ensaiavam as cenas que tinham sido escolhidas para filmarem. Eles saíram e filmaram na rua de frente à escola:

O professor orienta como será a gravação da cena 3. Eles vão para fora da escola para a primeira filmagem e se posicionam na rua da frente. Lá, o professor pede opiniões de onde os personagens poderiam vir, de que lado da rua para entrar na escola, lembrando, qual o lado mais bonito da rua, onde tem menos informações 
que não queriam mostrar e como ficará a luminosidade da cena e a posição do vento em relação ao microfone. Os alunos ficam atentos às suas explicações sobre esses aspectos. [...] Antes de começar, eles ensaiam a cena. Em seguida, fazem 3 tomadas da mesma cena e depois repetem a cena, porém, filmam em plano aberto. (Diário de campo - visita 18).

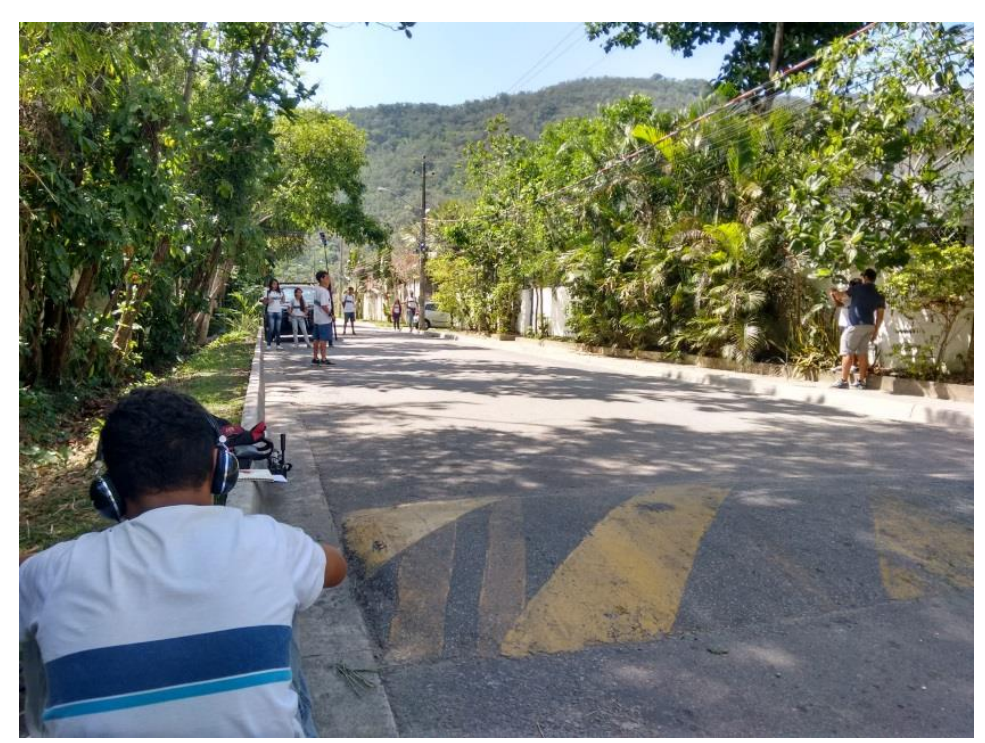

Figura 20 - Primeiro dia de filmagens

Fonte: Arquivo da pesquisadora.

Fizeram várias tomadas de uma mesma cena. Em seguida, entraram no pátio de entrada da escola e gravaram a continuidade dessa cena. Também fizeram várias tomadas, de diversos ângulos, da mesma cena. Depois de certo tempo, por conta do calor, os alunos que atuavam se mostraram cansados, pois tinham que repetir tudo. O professor avisou ao grupo que é assim mesmo, pois é preciso ter várias cenas, caso alguma não sirva, e eles contribuíram, demonstrando interesse e participando de todo o processo com atenção e entusiasmo.

Entre uma cena e outra filmada, o professor colocava os arquivos no seu computador para assistirem o que filmaram. Ele percebia as falhas de continuidade nos movimentos dos alunos, falava que os "atores" precisavam estar atentos e concentrados nas filmagens, pois a cada cena ruim, teriam que fazer tudo de novo, e isso era cansativo e desnecessário.

O grupo retomou as filmagens, agora já dentro da escola, em uma sala vazia, onde o professor montou o equipamento com auxílio de alguns garotos e o restante da turma organizou a sala. Eles filmaram várias tomadas da cena e repetiram pelo menos quatro vezes cada uma, sempre com um ensaio antes. Por fim, gravaram uma terceira cena, agora no pátio, onde estava ocorrendo 
uma aula de educação física, mas isso não foi problema, pois todos os alunos que estavam nesse ambiente se organizaram dentro daquela situação, como algo natural para todos. Da mesma maneira que antes, o professor explicou como seria a cena (agora também para os alunos da turma de educação física), eles ensaiaram e depois filmaram algumas vezes - os alunos que não eram da oficina atuaram como figurantes.

As orientações do professor foram simples e os alunos as seguiam e atuavam sem maiores dificuldades. Os que não estavam envolvidos diretamente nas cenas, seja atuando ou por trás das câmeras, ficaram por perto e assistiram a tudo, quando não atuavam como figurantes. Houve um movimento em torno daquela atividade e todos se envolveram no processo, dando palpites sobre como a aluna deveria atuar ou o que alguém precisava fazer em determinado momento, mas quem confirmava e indicava se poderia ou não ser assim era o professor.

Durante as demais filmagens, as aulas seguiam este esquema: o professor perguntava sobre o roteiro; depois, queria saber sobre as cenas que faltavam filmar; sentava com a turma e avaliava as cenas para escolher o que seria melhor fazer, dependendo do tempo e das salas disponíveis; avisava os alunos o que fariam e passava a montar os equipamentos junto com os alunos, enquanto outros se preparavam para filmar.

Nas primeiras gravações, ele pedia aos alunos opiniões sobre o melhor lugar para filmar, de onde a personagem deveria chegar, observando como ficaria mais bonito e melhor para edição. Com o passar dos dias, isso foi esquecido, e o professor, após avaliar a cena, já resolvia como seria tudo, apenas indicando aos alunos o que eles deveriam fazer e como. Assim, ele decidia quantas vezes iriam filmar uma cena, em quais ângulos e quantas tomadas, sem necessariamente pedir a opinião da turma e a partir do que conseguia realizar naquele momento. Nos últimos dias, conforme o fim do ano se aproximava e não havia mais tempo necessário para trabalhar melhor as cenas, ele filmava mais de uma vez cada cena para depois aproveitar o que fosse possível, como mencionou para mim em entrevista posterior.

No início, o aluno escolhido para ser o diretor do filme (Leo) participava mais ativamente, porém, passou a chegar atrasado e até faltou alguns encontros. Nas primeiras filmagens, o professor sempre perguntava quem seria responsável pela câmera, pelo som e pelo microfone, reportando-se aos meninos para essas tarefas. Com o passar do tempo e pela falta dos alunos, o 
professor passou a filmar, dizendo que se ele não fizesse dessa forma, poderia atrasar ainda mais a finalização da oficina. Assim, é o professor quem orienta como os alunos devem fazer as cenas, mas ele delega à turma tarefas, como: conseguir salas para filmar e chamar alunos para figuração. Em algumas filmagens, as meninas ficaram responsáveis pelo microfone ou pelo gravador, mas elas tomaram a iniciativa de pegar os equipamentos, pois não foram convidadas para isso.

Com os problemas que iam surgindo, o professor se chateava porque eles precisariam filmar novamente cenas já finalizadas. Uma aluna precisou sair da escola e foi preciso refilmar suas cenas. Depois, com a falta da aluna substituta, o professor resolveu regravar essas mesmas cenas com outra aluna fazendo o papel. Isso atrasou ainda mais o término do vídeo. Problemas como esse pareciam desestimular não apenas o professor, mas o grupo como um todo que já não participava das filmagens com grande entusiasmo como no primeiro dia. Mesmo assim, embora faltando, chegando atrasados e, em alguns encontros, aparentemente desinteressados e dispersos, os participantes da oficina realizaram as filmagens do vídeo.

Ter que terminar as etapas propostas da oficina para conseguir finalizá-la transformou-se em uma demanda que acompanhou as atividades durante o ano inteiro e percebi que, a partir de certo ponto, não se tratava de uma coisa leve e fluida, tanto para os alunos quanto para o professor, pelo contrário, parecia ser algo cansativo e desgastante. Isso pôde ser percebido pelas faltas dos alunos e também do professor por diversos motivos, o pouco interesse que aparentavam ter durante os encontros e as diversas aulas em que o professor precisava parar as atividades pensadas para o dia, porque iniciava uma conversa com a turma sobre a necessidade de maior interesse deles para o sucesso do projeto. As aulas canceladas por conta de reuniões, eventos, paralisações e greves também contribuíram para uma oficina com evidente falta de continuidade.

Por muitas vezes, imaginei que os alunos e o professor só estavam continuando $a$ ir à oficina por minha causa, pois sabiam que eu vinha de longe $e$ estaria lá para observá-los. Depois de alguns meses, esse fato passou a ser um dos argumentos do professor junto à turma para convencê-los a não faltarem a oficina ou para reclamar com os que haviam faltado e inviabilizado o encontro. Ele dizia: "Olha, a Pesquisadora vem de muito longe, vê se vocês não faltam, senão ela dá viagem perdida." E dei. Houve muitas visitas em que não fiz observação para preenchimento do protocolo porque não houve filmagens, pois 
algum aluno importante para a cena havia faltado. Assim, o professor acabava liberando os alunos e eu ia embora.

Embora um dos objetivos da oficina seja proporcionar um trabalho coletivo, o contexto e as dificuldades levaram o professor a comandar as atividades e as tomadas de decisão para acelerar as gravações, tomando para si as decisões que poderiam ter sido divididas com a turma.

Nesse tipo de projeto, o sucesso das filmagens está diretamente ligado à organização do grupo para que cada um contribua com suas competências e habilidades dentro da tarefa que lhe deve ser atribuída a partir de suas características ou não, numa tentativa de fazer experienciar outras possibilidades de produção, conforme já abordei no item sobre a divisão de tarefas. Ao explicar o projeto espanhol Cinema en curs, Berti (2016, p. 129) explicita a importância da experimentação de posições e lugares para o exercício do protagonismo de crianças e jovens nesse processo:

Os estudantes fazem tudo, do roteiro à montagem. Passam por todas as funções. Esse é um caráter importante, pois permite que todos experimentem posições e lugares. Isto é, os alunos são protagonistas em todo o processo. O roteiro é desenvolvido com a participação de todo o grupo, mas durante a filmagem, as posições ocupadas dentro das equipes de trabalho se alternam, para que todos possam desenvolver diferentes tarefas (cineasta, câmera, ajudantes, roteiristas) e no processo de montagem alternam-se em pequenos grupos dentro da aula.

A intenção do professor parecia ser esta, ao questionar quem faria o quê durante a filmagem do dia. Isso, porém, não teve continuidade no decorrer da oficina. No dia de testes do elenco, o professor usou uma filmadora profissional da escola. No primeiro dia de gravações, quando já estavam na rua a postos para começar tudo, a filmadora estava sem bateria, pois os demais alunos da escola haviam utilizado e não se lembraram de recarregar. A partir desse dia, o professor resolveu fazer as filmagens com seu próprio celular que tinha uma excelente definição para captação de vídeos. Acredito que seu maior interesse em manusear o celular nas filmagens também estava ligado ao cuidado com o aparelho, pois tratava-se de um produto muito caro. O aluno-diretor, Leo, orientava os ensaios e algumas cenas. Na maior parte das gravações, quem indicava o que deveria ser feito era o professor. Isso dependia muito do dia e do clima da turma com relação às filmagens:

Eles filmam 5 tomadas da cena. Todos participam da gravação e cumprem os combinados e repetem as ações nas repetições. Depois, o professor faz a cena de novo, mas faz 2 tomadas com foco na ação das personagens conversando. Leo fica um pouco à parte da gravação, mas o professor chama a atenção dele e ele passa a participar mais. O professor resolve fazer um plano geral da sala e para isso precisam de mais alunos na cena. Leo e Carla saem para conseguir alguns 
alunos para figuração. Eles trazem colegas que, inclusive, participaram das turmas que desistiram da oficina este ano. Depois que estão sentados, Leo explica a eles o que vai ocorrer e o que eles precisam fazer. (Diário de campo - visita 19).

A cena foi filmada no pátio, pouco antes do recreio. Eles ensaiaram algumas vezes antes de filmar. Vítor fica responsável pelo microfone e o professor pela câmera no celular. O professor orienta a movimentação dos alunos na cena e diz também o que devem falar. Igor e João parecem não saber nada do texto. (Diário de campo - visita 22).

As escolhas do que será filmado e de como isso será feito são essenciais na criação de um filme e, em projetos dessa natureza, geralmente o diretor do filme também se responsabiliza pela câmera. Portanto, quem está com a câmera (orientado ou não por um diretor) é responsável por: enquadrar, tomar decisões, ocultar/revelar, criar - para citar atos envolvidos na produção de filmes na escola, indicados por Fresquet (2014). Esses (e outros) verbos constroem o ato criativo do cinema na escola. Pires (2014, p. 126) conta uma experiência vivenciada em um projeto com jovens, que a fez perceber a importância de trabalhar a questão do olhar nessas atividades:

Mesmo já tendo incentivado e delegado poderes aos alunos em alguns vídeos e incentivá-los a dirigir todo o processo de produção audiovisual, como foi efetuado no vídeo Aristides em Ação, percebíamos que a ação poderia e deveria ser mais autoral, e o olhar fazia parte desse processo. Quem vai conduzir a câmera? Quem vai selecionar o que é importante ser filmado? Eram perguntas que sempre repetíamos para colocar em suas mãos a direção do vídeo. [...] O "virar de pernas para o ar" foi provocado por um aluno específico: o Jf. Não podemos esquecê-lo e guardamos na memória com carinho, porque, de aluno um tanto difícil de lidar, passou a ser o provocador de um marco, um rompimento radical na relação que estabelecíamos com os alunos na produção audiovisual, pois, nos fez perceber que o Olhar daquele que domina a câmera representa a subjetividade, dimensão fundamental que nós nunca havíamos considerado. Esse deslocamento de posição: da passividade, já que nos entregavam a direção e toda a organização das cenas até se transformarem nos autores da ação.

Para que isso ocorra, é importante não apenas entregar a câmera nas mãos dos alunos para que eles filmem também, acionando o play quando necessário, mas permitindo a eles mostrar aquilo que eles querem, dando-lhes poder de decisão sobre o que será mostrado. Algumas vezes, essa vontade de filmar parte dos próprios alunos:

Os alunos estavam sentados, e mantinhamo-nos de pé com a filmadora na mão registrando todo o debate e ao mesmo tempo levantando alguns questionamentos para provocar as discussões e aprofundar o tema tratado. Num certo momento, um aluno tomou a câmera da minha mão, com tanta propriedade, e disse: - Agora sou eu que filmo, Pró. Foram alguns segundos de impasse. Em nenhum trabalho havíamos vivido aquela situação. Todos sempre aceitaram passivamente a nossa tarefa como cinegrafista. Aquela simples atitude marcou uma nova forma de pensar o trabalho de produção audiovisual. Representou uma mudança de paradigma. Uma mudança de OLHAR. (Pires, 2014, p. 125, grifo no original). 
Embora os equipamentos sejam caros, é necessário acreditar que os alunos cumprem aquela atividade com seriedade, determinados a fazer o seu melhor. Os resultados podem ser reveladores:

Com a apropriação da filmadora, Jf representou um movimento simbólico que eles, os alunos, os jovens que participavam do processo de produção audiovisual tinham de ser os Sujeitos do OLHAR. O trabalho de direção da produção audiovisual exige alguns elementos subjetivos que até então considerávamos que poderíamos capturar, pois tínhamos sensibilidade e ouvíamos as colocações, anseios, sugestões que nos eram indicadas nos momentos de filmagem. Considerávamos que poderíamos abarcar a diversidade presente nos olhares dos jovens que participavam do processo de produção daqueles trabalhos. (Pires, 2014, p. 126).

Oportunizar a relação com a câmera pode ser importante também para que os alunos percebam como se sentem naquele papel. Mesmo que não seja com o intuito de fazê-los contar uma história, no sentido de elaborar cenas previamente pensadas, a simples relação com um equipamento de filmagem é relevante:

Perguntamos posteriormente a Jf pelo Facebook, o que o fez tomar aquela atitude, já que nunca dávamos liberdade aos alunos de manusear a filmadora: "Tipo eu queria ser um câmera-man, aprender a usar, saber manusear. Acho que poderia fazer melhor, pois sou aluno, a minha mente está mais evoluída para as tecnologias e a senhora tem de dar oportunidade aos alunos, pois eles vão acabar surpreendendo." (Jf, ex-aluno do Colégio, atualmente dançarino na Turquia). O desejo de ter a subjetividade valorizada fez Jf tomar uma atitude e nos destronar do papel de detentoras do olhar. (Pires, 2014, p. 125).

O professor comentou diversas vezes comigo sua preocupação com o risco de não conseguirem terminar o filme. Quando estávamos chegando perto do final do ano, questionei se ele já havia pensado em como seria feita a edição do material e ele respondeu que se conseguisse terminar as gravações, já estaria satisfeito. Demonstrou descontentamento com a turma desde quando os alunos começaram a faltar e suas faltas comprometiam todo o trabalho. Os alunos também estavam bastante desestimulados e, muitas vezes, as filmagens ocorriam só para terminar, como o professor comentou posteriormente. A falta de motivação de todos a partir de certo ponto da oficina vai de encontro ao que a maior parte das pesquisas sobre produção audiovisual na escola aponta, ao avaliarem esse momento como de grande interesse por parte dos envolvidos, como salientam Nakache (2011) e Garbin (2011).

O último dia de filmagens foi bastante tumultuado, pois as gravações seriam na casa de uma aluna e nesse dia seriam publicados os resultados finais das avaliações, quando os estudantes saberiam que havia passado ou não de ano. Eles gravaram a cena final, em que a garota que pensava estar sendo 
traída chegava à casa da amiga e era surpreendida com uma festa surpresa feita pelos colegas. A turma organizou uma festa de verdade para festejar o fim da oficina. Jonas e os alunos levaram pipoca, biscoitos, bolo e refrigerantes, montaram uma mesa de aniversário e no final das filmagens festejaram também por todos terem passado de ano. Esse dia trouxe evidências de como os alunos conseguem se organizar mediante demandas apresentadas pelo professor. Toda a festa foi elaborada por eles e a cena foi filmada a contento por todos. Embora tenha sido uma oficina repleta de percalços, os estudantes e o professor chegaram contentes ao fim.

\section{* Edição e veiculação}

Desde o início das observações, o professor havia comentado comigo que ele mesmo ficava responsável pela edição dos filmes, assim como acontece em muitas oficinas de cinema na escola (Husbye, 2013; Machado, 2017; Pimentel, 2013). Até a finalização da escrita desta tese, não há informações se esse vídeo foi ou não finalizado. Em entrevista pós-oficina, Jonas disse que terminaria o filme quando tivesse um tempo livre. Sem material editado, não há veiculação do vídeo.

Entre os momentos importantes para uma oficina de produção audiovisual, Fantin (2014) cita a pós-produção - quando são feitas edição e acabamento do vídeo produzido - e a veiculação, momento em que o produto final é apresentado para os autores e o grupo, a fim de socializar a experiência. De um modo geral, os projetos de produção de vídeo na escola não conseguem realizar coletivamente a edição por falta de organização do tempo - não se prevê no planejamento do processo o tempo a ser dedicado à edição - e por falta de equipamentos adequados, como computadores com boa configuração para processamento de imagem, além de um programa de edição de qualidade, com os recursos necessários. Muitas vezes, a edição fica a cargo do professor ou de outras pessoas com tempo e formação necessários para executá-la. As pesquisas que constatam que os alunos conseguiram realizar a edição dos vídeos sozinhos, geralmente analisam atividades realizadas com estudantes do ensino médio ou mais experientes (Berti, 2016; Labrunie, 2017; Miranda, 2015; Nogueira, 2014). Nos projetos em que foi possível realizar a edição com a participação dos alunos, estes geralmente participam como espectadores da edição, dando algumas ideias, mas para isso é necessário ter organizado previamente esse momento, como conta Diniz (2014, p. 276): 
Convido para que se aproximem, formando uma meia-lua em volta do editor. [...] Os planos que deram certo são separados, os que possuem algum problema são descartados, não sem antes ser motivos de riso e deboches. Aos poucos, eles vão entendendo a dinâmica da montagem. O objetivo não é aprender a técnica e os comandos do programa de edição (seria muito difícil em poucas horas), mas sim compreender que a associação entre dois planos produz uma ideia, e dependendo de nossas escolhas o filme vai para um lado ou para o outro.

Muitas vezes a edição do vídeo é feita à parte, fora da escola e sem a participação dos alunos porque se trata de uma atividade demorada e de interesse de poucos. O próprio Diniz (2014, p. 276), que tinha uma metodologia organizada para esse momento da oficina, relata isso:

Parece divertido no início, quando eles começam a ver a pista de imagem e de áudio combinando e dando a ver um filme. Mas nem todos se interessam. Há uma procura incessante pelo banheiro. É realmente uma aula mais parada. Os alunos ficam mais passivos diante do equipamento, e, mesmo sendo provocados a toda hora por mim para que elejam os melhores planos para as sequências a serem montadas, ele ficam impacientes. No final do dia, são três ou quatro mais interessados colados no editor. Os demais estão no fundo da sala em conversas paralelas.

É impossível manter o interesse de todos os alunos durante todos os processos envolvidos em uma oficina de produção audiovisual e talvez esse seja o maior desafio de professores em relação a uma metodologia que promova uma experiência de sucesso na escola. A oficina não pode ter em vista apenas a exibição do filme, pois de acordo com Bergala (2008, p. 173):

Em situação escolar, o objetivo primeiro da realização não é o filme realizado como objeto-filme, como "produto", mas a experiência insubstituível de um ato, mesmo modesto, de criação. No gesto de fazer, há uma virtude de conhecimento que só passa por ele. O "sucesso" do objeto-filme, no sentido de seduzir um público de pais se alunos ou de colegas, não garante de modo algum o que é dito na célebre frase de Moonfleet: "o exercício foi proveitoso".

Quando a edição é uma tarefa cumprida pelos alunos, sob a orientação do professor, como apresentam Kearney e Schuck (2005), eles podem ser encorajados a adotarem uma abordagem lúdica também nas edições, por parte dos professores, pois a partir de atividades mais livres os alunos descobrem seus próprios erros e aprendem com eles:

O feedback imediato que os estudantes receberam quando revisaram seus filmes, bem como a capacidade de editar seus erros posteriormente, ajudou alunos e professores a se sentirem confortáveis com essa abordagem aberta ao aprendizado. ${ }^{68}$ (p. 6).

\footnotetext{
${ }^{68}$ Tradução minha do original: "Many teachers encouraged the students to take a playful approach to their filming and editing and set up very open-ended activities for them to discover their own mistakes and learn from them. The immediate feedback students received when they reviewed their films, as well as the ability to later edit their mistakes, helped students and teachers feel comfortable with this open-ended approach to learning."
} 
Conforme compreendem os autores citados, essa é uma abordagem mais aberta por parte do professor para lidar com um "estilo autônomo de aprendizagem, exigindo um grau significativo de flexibilidade do professor, pois os alunos criavam seus próprios caminhos de aprendizagem em seu próprio ritmo." ${ }^{69}$ (Kearney \& Schuck, 2005, p. 7).

No caso da oficina observada, desde o início das filmagens o professor comentava comigo que dificilmente conseguiriam terminar as gravações e, caso isso acontecesse, seria impossível editar o material que, de acordo com ele, estava muito ruim. Tendo em vista que ele já previa isso, talvez fosse interessante trabalhar as imagens produzidas na oficina de outra maneira. Realizar, por exemplo, a edição curta de uma seleção de cenas em que os "atores" erraram as falas, em meio a risos e brincadeiras, ou de outras em que os demais alunos da escola e professores aparecem nas cenas, ou ainda com os melhores momentos da oficina ofereceria a oportunidade a todos de compreender como é feito um processo de edição e de discutir a importância disso na estruturação da linha argumentativa do vídeo. Bergala (2008, p. 174) apresenta algumas sugestões: "Dentre as soluções possíveis, uma consiste em mostrar na mesma sessão tanto o processo (os exercícios que precederam a fase de realização, alguns copiões, várias montagens da mesma cena) quanto o resultado desse processo." Enfim, as possibilidades de mostrar o que foi realizado durante a oficina podem ser muitas, dependendo do objetivo que se tem em relação à oficina e ao que foi produzido e o momento de veiculação do produto final permite ao grupo ver finalizado o resultado de seu trabalho e compreender como o que foi realizado antes se transformou em vídeo.

A perspectiva mídia-educativa considera a edição como etapa fundamental da literacia midiática, pois possibilita a compreensão mais plena da estrutura da "gramática" da linguagem e o exercício da autoria criativa. Embora esse filme não tenha sido finalizado, os filmes produzidos com estudantes nas oficinas desse professor são frequentes em mostras e festivais abertos para o audiovisual escolar. Alguns deles foram selecionados, inclusive, em várias edições da Mostra Geração do Festival de Cinema do Rio, o que sugere que são valorizados e reconhecidos no contexto do audiovisual escolar.

A divulgação do vídeo é importante para a comunidade escolar, funcionando como uma "prestação de contas" do que foi feito durante o tempo

69 Tradução minha do original: "The autonomous style of learning supported by these open-ended tasks required a significant degree of flexibility from the teacher as students created their own learning pathways at their own pace." 
daquela oficina e, ao mesmo tempo, como uma avaliação final das atividades. Kearney \& Schuck (2005) consideram que os alunos precisam de uma oportunidade para "celebrar seu aprendizado" e a apresentação do projeto seria um estágio crucial para que eles articulem aprendizagens e discutam os conceitos subjacentes de seus filmes. Ver o que o grupo produziu pode ser um momento de aprendizagem da linguagem audiovisual (ao compreenderem o que foi produzido pelo grupo e indicarem mudanças para melhoria do vídeo) e uma oportunidade para compreender como o trabalho individual de cada um contribuiu para a criação coletiva. Nesse momento, é possível que os alunos tomem maior consciência sobre a importância de sua participação, compromisso, assiduidade, motivação, organização e planejamento para contribuir com o trabalho do grupo - sendo estas habilidades, entre outras, desenvolvidas durante todo o processo.

Além disso, os projetos geralmente apresentam os filmes nas escolas e esse momento estimula outros alunos a participarem das oficinas que porventura venham a ocorrer futuramente, como é o caso da escola desta pesquisa. Hobbs \& Moore $(2014$, p. 31) destacam outro relevante aspecto da veiculação dos vídeos criados nos projetos:

Como a documentação do processo de aprendizado é tão desigual e geralmente não é padronizada - e, portanto, muitas vezes pouco atraente para as secretarias de educação e outras instituições acadêmicas - o produto acabado pode ser o único resultado obviamente útil do processo de criação da mídia juvenil. Tais expectativas muitas vezes levam naturalmente a modelos de aprendizado nos quais um "professor mestre" é responsável por projetos concluídos, enquanto os estudantes participam em vários níveis (de "supervisor de roteiro" a "diretor"), dependendo de seus interesses, competências e habilidades. ${ }^{70}$

Muitas vezes, projetos com foco nas tarefas e nos prazos a cumprir acabam deixando de lado o processo criativo e a relação com a linguagem, momentos considerados mais importantes do que a finalização de algo a ser apresentado à comunidade. A aposta em oficinas voltadas para a inscrição do vídeo em mostras estudantis pode, em muitos casos, contribuir pouco para aprendizagem e o desenvolvimento dos estudantes nessa atividade.

A veiculação pressupõe edição do material filmado, ou um mínimo tratamento do que foi construído ao longo da oficina para apresentação ao

\footnotetext{
70 Tradução minha do original: "Because the documentation of the learning process is so uneven and is usually not standardized - and thus often unattractive to school districts and other academic institutions - the finished product may be the only obviously useful outcome of the youth media creation process. Such expectations often lead naturally to apprenticeship models in which a "master teacher" is responsible for a completed projects, while students participate at various levels (from "script supervisor" to "director") depending on their interests, competences, and abilities."
} 
grupo. Para alguns estudantes, o processo pelo qual passaram só passa a fazer sentido quando eles assistem ao vídeo, conforme explica Pires (2014, p. 132):

Na semana seguinte, já com a matriz do vídeo produzido em formato de DVD, exibimos o vídeo para os alunos e só assim puderam perceber como deveriam conduzir a filmagem, os pontos que necessitavam melhorar na parte técnica, pois muitas imagens ficaram perdidas devido ao manuseio inadequado da filmadora. Constataram também a relevância de construir um roteiro para as entrevistas, mesmo que fizessem alterações no local caso fosse necessário.

Durante toda a oficina observada, os estudantes conviveram com os cartazes dos filmes de oficinas anteriores realizadas na escola, reportando-se a eles quando necessário e comentando aqueles que haviam assistido. Acredito que a turma esperava ver o filme que estavam produzindo pronto e apresenta-lo a seus pares, o que não aconteceu. Kearney \& Schuck (2005) relatam que os estudantes se mostram muito mais motivados nas atividades de produção audiovisual quando têm consciência de um público-alvo real para apresentar suas produções. Os autores indicam que os melhores resultados das pesquisas estão relacionados a este momento:

Talvez os dados mais importantes nesta parte do estudo tenham sido os estágios finais do projeto de vídeos digitais: "celebrar" e compartilhar os produtos finais dos alunos e conduzir discussões sobre esses artefatos. Essas apresentações proporcionaram oportunidades significativas para discussões significativas centradas nos resultados pretendidos de aprendizagem dos projetos. (p. 8).

Nesse momento, conforme entendem Kearney \& Schuck (2005, p. 8), é imprescindível a mediação do professor nessas discussões. Além disso, a disseminação e a publicação de produtos de estudantes precisam ser levadas em consideração, entre os quais se incluem festivais de filmes escolares, conferências conduzidas por estudantes, competições externas de filmes, intercâmbios culturais internacionais e programas de TV, conforme Jonas costuma realizar com os filmes produzidos em suas oficinas.

Apenas no primeiro dia de filmagens o professor viu com a turma o material que estava sendo produzido, mas no restante do processo não foi possível ter contato com as cenas gravadas. Quando questionado sobre o que fará com as cenas, ele explicou que pretende editá-las no próximo ano, caso esses alunos se inscrevam na oficina novamente:

O filme está todo dentro do computador. A minha ideia era tentar montar um esqueleto e ir. Não... Eu não queria nem fechar o filme nas férias, porque eu queria ver se os alunos que estavam o ano passado vão continuar. E aí, se eles se inscreverem, a ideia é que a gente pudesse meio que terminar o filme juntos. [...] ele já tá meio que organizado, já tá separado por cenas, tá todo pronto ali. $\mathrm{E}$ eu já até descartei cenas que não ficaram boas, já sincronizei o áudio, então ele tá agora nesse momento. Só que aí eu não sei como é que vai ser, se a oficina não 
acontecer, aí eu vou finalizar o filme e ele vai ficar pronto do jeito que está. (Professor Jonas).

\section{Com a palavra: o professor da oficina}

Ao questionar o professor sobre seus objetivos com a oficina, em entrevista realizada após a finalização do processo, ele respondeu que a produção de um filme era algo relevante:

O segundo objetivo que eu espero, o resultado que eu almejo, é que a gente consiga produzir pelo menos um filme... Tenha um trabalho concluído pra que a gente possa validar o processo inteiro, né, de passar por todas as etapas. [...] Mas surgem outro resultados, com o tempo, e que eu já prevejo que eles podem acontecer, mas não são resultados que eu dependo deles, por exemplo, sei lá, o filme ir pra um festival, e aí sim ele poder expandir, uma troca com outras escolas, ter um intercâmbio com outros alunos, com outros jovens de outros lugares que estão produzindo também esse conteúdo audiovisual, isso seria um resultado que eu prevejo, mas que eu não conto com ele. Ele é uma coisa que pode acontecer ou não. (Professor Jonas).

Essa fala mostra que ele também previa a finalização do filme para a veiculação dele na escola e fora dela. Fez uma autoavaliação ao ser questionado sobre como percebeu a oficina desse ano, dizendo que poderia ter finalizado melhor o processo, pois não houve uma avaliação final junto com a turma. Ele diz estar reorganizando a metodologia de trabalho:

[...] para o ano que vem eu já fiz um novo projeto de trabalhar de uma forma completamente diferente, eu vou trabalhar por bimestre, não vou trabalhar mais dessa forma de iniciar um roteiro. A minha ideia é que a cada bimestre a gente produza algum vídeo. Então, vai ser tudo muito mais rápido, não vai ser tudo tão profundo, mas a ideia é tentar segurá-los mais tempo no bimestre, e se no bimestre seguinte não tiver, eu tenho outra turma e a gente vai tentando mesclar e abrir novas vagas, enfim, vou mudar o sistema de vagas também. (Professor Jonas).

Kearney \& Schuck (2005, p. 8), recomendam procedimentos de avaliação formativa durante quase todas as etapas de produção audiovisual:

Estes incluem a avaliação pelos pares e encorajamento da discussão em grupo e partilha de perspectivas em todas as fases do processo, incluindo o uso de comunidades de filmagem on-line para este propósito. A observação do professor e o feedback também são cruciais, especialmente nos estágios iniciais importantes do processo.

Desde os últimos meses de observação da oficina, o professor já havia comentado comigo que estava pensando em outra proposta metodológica, tendo em vista o abandono das turmas desse ano. Sua fala indica que ele percebe a atividade do roteiro como algo profundo e que sua intenção, nas próximas oficinas, é abordar mais a produção. A ocupação das vagas da oficina também surge como algo a ser modificado. Sobre esse tema, é relevante pensar em 
como a oficina é ofertada na escola: no início do ano, o professor visita as salas, explica do que se trata e ali mesmo os alunos indicam seu interesse em participar. Pimentel (2013, p. 25) faz uma análise desse tipo de abordagem em sua pesquisa:

Para se inscrever, o aluno deveria comparecer à Direção da escola e preencher uma ficha de inscrição. Este procedimento foi importante visto exigir do aluno um deslocamento físico para manifestar seu interesse. Optamos por esse procedimento, pois consideramos que, se os alunos pudessem se inscrever na sala de aula, na hora em que passamos divulgando, provavelmente haveria um número muito maior de inscritos que, no calor do momento, se disponibilizariam em participar. No entanto, ao pensarem melhor, muitos tenderiam a desistir da oficina, ao perceberem que teriam que comparecer na escola duas tardes por semana, realizarem estudos/leituras além das que regularmente já tinham a obrigação de fazer, talvez abrirem mão de um estágio remunerado etc.

A oficina observada nesta pesquisa ocorria às terças-feiras pela manhã e os alunos deveriam passar esse dia inteiro na escola, pois suas aulas aconteciam à tarde. Esse pode ter sido um dos motivos que fez alguns alunos desistirem. Embora não seja comum, pesquisas registram a desistência de alunos das oficinas por diversos motivos, como priorizarem estágios remunerados (Pimentel, 2013) ou precisarem estudar para disciplinas em que tiveram notas baixas, como relata Pacheco (2015, p. 212), que também acompanhou oficinas em meio a greves de professores, indicando ser este um dos motivos que enfraqueceram a frequência das turmas:

Apesar de ter tido mais de 30 jovens inscritos, apenas seis educandos, dos 17 aos 20 anos, estavam a frequentá-la, e isso se deu em todas as oficinas que acompanhamos no Brasil. Se em Portugal um dos principais motivos da desistência dos jovens, nas oficinas optativas de cinema, e a necessidade de utilizar o horário para aulas de apoio e estudo, no Brasil o motivo foi a greve dos professores.

Em relação às desistências, Jonas considera ser preciso alguma mudança porque o modelo já está desgastado. Ele relata que em outra escola, onde começou há pouco tempo um trabalho semelhante, os alunos estão bastante interessados:

[...] também eu acho que tem um desgaste, é uma escola em que eu já estou há, sei lá, 17 anos... Já faço esse projeto desde 2003, então... Não é um projeto que é novidade, né, então, é mais difícil. Quando você chega numa outra escola, e ainda é novidade, é o terceiro ano que estou lá, ainda tem uma procura muito grande. Então... Não sei, não sei se é um cansaço - se é o cansaço, eu digo, dentro do processo... O processo tá cansado, talvez precise renovar realmente, precise dar novos ares pra ele funcionar melhor. (Professor Jonas).

Mesmo tendo avaliado como um processo que necessita de mudanças, o professor considera que algumas etapas funcionaram bem: 
Eu acho que a primeira etapa, o primeiro bimestre, a parte da escrita funcionou bem, e a parte da gravação, mesmo com alguns percalços, com a saída de uma aluna, essas trocas que a gente teve de fazer, no final deu certo. Acho que eu consegui que eles se apropriassem algumas vezes de fazer algumas coisas, de estar com a câmera na mão, de experimentar, de vivenciar mesmo, entender essas coisas... Eu acho que funcionou dentro do que estava previsto, eu acho que funcionou. Nesses dois momentos, talvez, no momento de escrever e o momento de gravação acho que funcionaram melhor. E acho que talvez o pior momento tenha sido da escrita do roteiro mais complexo e que a gente se estendeu muito. Poderia ter sido mais enxuto. (Professor Jonas).

Tendo em vista o objetivo do professor, de oportunizar um maior contato com a escrita através da construção do roteiro do filme, é possível dizer que a oficina cumpriu seu objetivo. Embora tenha sido diferente da realizada nos anos anteriores, conforme indica o professor, ele conseguiu chegar ao término das gravações e cumpriu a maior parte do que havia proposto para aquele ano. Ao avaliar o produto final das gravações, a partir do que ele disse ter organizado das cenas e dos áudios, o professor avalia o produto da seguinte forma:

Acho que no final, também, o resultado do filme, enquanto filme, eu acho que ele não é tão bom, em termos de filme, falando do produto "filme", ele não é tão bom quanto eu gostaria que fosse. Mas também isso faz parte, errar também faz parte. Acho até que a ideia que a gente tinha da outra turma anterior era mais interessante, do roteiro, do que essa. E aí, eu não sei. Eu não sei se o filme vai ter um bom resultado... Eles assistirem e gostarem, então, isso também é uma fase em que eu me preocupo, depois. Porque a ideia é que a gente tivesse conseguido terminar antes e ter exibido no final do ano. Como isso não foi possível... A turma já se perdeu, então a gente não vai poder sentar e assistir o filme juntos e avaliar e falar: "Ah, aconteceu isso, isso e isso", "Ah, aqui poderia ter sido melhor", ou não, enfim. Então, talvez a gente não consiga ter esse momento, vai depender do que eles vão querer, se eles vão continuar ou não, se vai ter oficina. (Professor Jonas).

Jonas demonstra saber da importância de ver o filme após a finalização pelo menos junto com a turma que o produziu para discutirem possíveis melhorias e tratarem do processo. Como não houve tempo para isso, essa possibilidade ficou suspensa, dependendo do que viesse a acontecer com a oficina e até mesmo se os alunos daquela turma iriam retornar no futuro. Por fim, avalia da seguinte maneira a oficina aqui descrita:

Eu faço a minha avaliação: eu acho que eu errei em algumas questões esse ano porque fui surpreendido por essas mudanças, por esses abandonos, e acho que errei porque eu não sabia como é que ia funcionar esse novo sistema de turmas da escola. Então, eu atribuo muito do que aconteceu a uma falha minha. Mas eu acho que mesmo com as falhas, mesmo com tudo isso, eu acho que de alguma maneira eu contribuí, pra que eles pudessem abrir uma nova possibilidade, sabe? Abrir um novo leque e que... Eu não sei se eles vão ter oportunidade de continuar ou vão querer continuar, mas eu acho que sempre é válido, eu sempre acredito que essa experiência por menor que seja, seja um mês que ele participou ou dois, eu sempre acredito que a gente abre possibilidades, sabe? Até de ele perceber que é capaz, enfim, principalmente pelo fato das histórias serem escritas por eles. Então, pra mim, o mais importante é que eles percebam que "Caramba, esse 
filme, fui eu que criei! Saiu da minha cabeça!". Então, "Pô, então, eu posso, eu sou capaz, eu consigo fazer alguma coisa bacana, alguma coisa legal!" (Professor Jonas, 2018).

O docente se refere às mudanças de turma porque a escola dividiu as turmas por turnos ( $6^{\circ}$ e $7^{\circ}$ anos com aulas à tarde e $8^{\circ}$ e $9^{\circ}$ anos pela manhã), o que mudou um pouco a organização da oficina, pois dessa maneira os alunos ficavam separados por série. Em sua fala, fica claro que ele concorda que é importante ter um filme pronto para que os estudantes vejam como foi relevante terem criado algo, mas isso não foi possível nesse contexto. Ele continua sua avaliação, indicando a necessidade de se reinventar "em alguns aspectos":

[...] atualizar, porque os anos vão passando e as coisas vão mudando... Hoje, a gente tem essa coisa de celular muito forte, que eu não tinha há quatro, cinco anos atrás, uma distração que o tempo inteiro tá ali... Então, eu também preciso me readaptar, mas é um exercício que eu gosto de fazer, sabe? (Professor Jonas).

\section{* Com a palavra: os alunos}

Em entrevista realizada ao término da oficina, no último dia de filmagem, os alunos responderam algumas questões em relação à oficina. Eles usaram cartões para representar suas opiniões, pois eu tinha receio de que não participassem ativamente da entrevista. A partir dessas contribuições, apresento a visão deles sobre o processo de trabalho que foi feito na oficina.

Sobre as expectativas em relação à oficina:

Pesquisadora - O que é que vocês achavam que iam fazer aqui?

Vanir - Eu achava que a gente ia aprender a editar, a gente ia aprender a mexer na câmera, tipo regular, essas coisas. Eu não imaginava muito que a gente ia...

Leo - Gravar um filme.

Vanir - Gravar um filme.

João - Eu também.

Carla - Eu também.

Pesquisadora - Vocês ainda não tinham ouvido falar o que acontecia de quem já tinha feito a oficina?

Vita - Ano passado... Eu vi uma cena gravando.

Vanir - Mais ou menos.

Carla - É que essa oficina no ano passado só teve do $7^{\circ}$ ano pra cima. Não tinha pra gente do $6^{\circ}$.

Leo - Eu vi algumas pessoas gravando, achei que fosse algum trabalho, não achei que fosse aula da oficina, pensei que fosse um trabalho de escola.

Sobre a construção do roteiro coletivamente, Leo reclamou de como a turma se comportou, dizendo não ter gostado: "no momento que a gente estava escrevendo as pessoas ficavam muito deslocadas, rindo, brincando, eu escrevi 
praticamente o roteiro inteiro porque as pessoas estavam todas conversando. Então, pra mim não foi tão legal." Keyla disse que foi vergonhoso o processo, justificando sua resposta: "Porque era assim, ele [Leo] saía do computador, aí passava pra outra pessoa e quando a outra pessoa ia coisar, aí ele pegava e ficava dando fora nas pessoas, falando que ele escreve mais rápido, essas coisas assim." No final dessa discussão, João disse ter gostado e quando perguntei o motivo, ele responde: "Ah, porque todo mundo gravando, deu tudo certo." Por fim, perguntei sobre um cartão com imagem de alguém atarefado que um deles havia colocado à mesa:

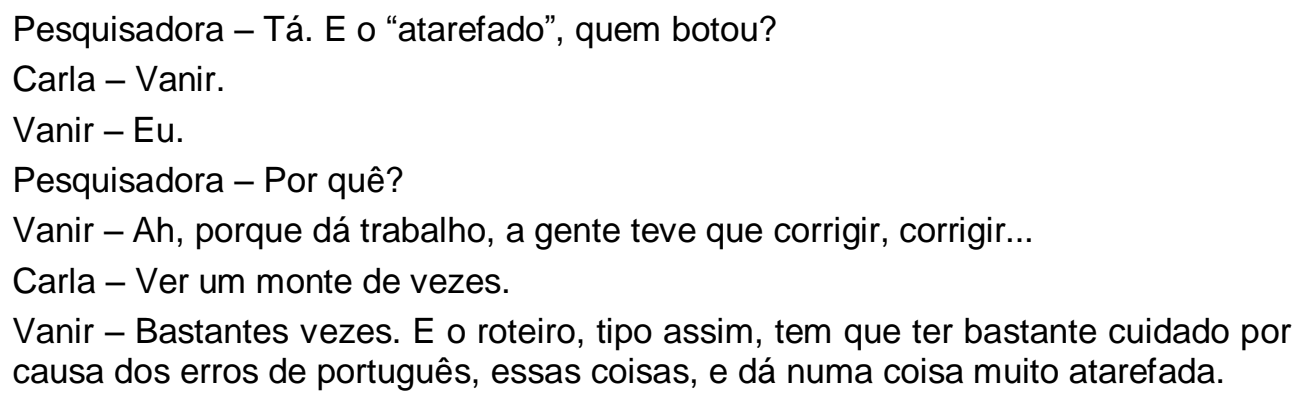

Pelas falas dos alunos, a escrita do roteiro foi um momento difícil da oficina, porque deu muito trabalho ou porque nem todos participaram de modo a construir juntos. Vanir e Carla deixaram claro que foi uma tarefa difícil e que ficar atenta a erros de escrita era algo que dava bastante trabalho. Isso indica que a atenção dos alunos parecia estar mais voltada para a questão da escrita correta do que para a criação de uma história bem construída, o que compromete, em parte, os objetivos traçados pelo professor: aperfeiçoar a escrita e expressar bem as ideias.

Sobre a divisão dos papéis, alguns participantes não conseguiram nomear suas funções durante as gravações:

Pesquisadora - E você fez o quê, no filme?

Keyla - Como assim?

Pesquisadora - Você participou do filme. Ela fez um personagem, ele fez um personagem, ela também. E você fez o quê?

Keyla - A única coisa que eu fiz do filme foi... Foi lá fora quando o Igor ficou com a Samara, que ele falou pra Vanir que ela foi sorteada.

Pesquisadora - Você fez figurante. (Keyla acena com a cabeça confirmando). E você? Também? (para João, que também confirma com a cabeça). Vítor, fez o quê?

Vítor - Trabalhei no microfone.

Pesquisadora - E você, Vita, você fez o quê?

Vita - Fez o quê...

Pesquisadora - Não, você fez o quê, no filme?

João - No filme. 
Igor - Nada.

Vita - Eu só entrei na sala, fiz a personagem da sala, andei na rua...

Pesquisadora - Então, você foi... Figurante. Você [para Leo]?

Leo - Eu ajudei a gravar várias cenas e também tive as ideias pro roteiro e pra história.

A falta de domínio sobre as funções desempenhadas na produção audiovisual demonstra que eles não estavam atentos à divisão de papéis ou não haviam aprendido isso durante a oficina. Como descrito na pedagogia do professor, ele apresentou uma vez os papéis possíveis para os estudantes, mas nesse dia, Vita não estava na aula, e talvez por isso ela não sabia dizer qual sua função no filme. Em outra parte da entrevista feita com o grupo, Igor deixou claro que o papel do diretor era indicar o que deveria ser feito nas cenas. Eles estavam avaliando como havia sido o trabalho em grupo na oficina:

Pesquisadora - Por que foi difícil?

Leo - Porque algumas pessoas não estavam tão comprometidas com o trabalho da gente.

Pesquisadora - E isso mostra o quê?

João - Você também teve um dia que faltou. (Referindo-se à Leo)

Pesquisadora - Quando as pessoas faltam, demonstram o quê?

Leo - Mas comprometimento não é só vir, não.

Vanir - É... Demonstra desinteresse. Não! Dependendo do motivo. Pode ser, um motivo, tipo assim: "Ah, eu vou faltar" - demonstra um pouco de desinteresse. Mas teve coisas que, na minha opinião, o Leo abriu mão, tipo assim, às vezes, algumas cenas que a gente ia fazer, ele não ficava presente pra falar assim: "Ah, tá bom", "tá errado", "tá certo"...

João - "Faz isso, faz aquilo..."

Pesquisadora - Mas por que ele tinha que fazer isso?

Igor - Porque ele é o diretor.

Vanir - Porque ele se colocou no lugar de ser diretor.

Pesquisadora - Ah, tá.

Leo - Mas eu fiz isso, hoje. Fiz todas as vezes.

João - Não!

Carla - Às vezes, não fez.

Leo - É, não fiz (disse isso em tom de ironia). Você não tava nem lá. Você tava conversando (falou para João).

As disputas nesse grupo durante toda a oficina eram constantes, ou porque alguém não estava ajudando e ficava conversando, ou por faltarem e isso era visto como desinteresse pelo grupo e pelo professor. Como eram bastante cobrados por faltar, alguns alunos acabavam desistindo da oficina. Esses problemas certamente atrapalharam o andamento das atividades. Os alunos mencionaram as dificuldades de trabalhar nesse grupo:

Carla - Porque, assim, pra gente fazer o filme, a gente precisou conhecer todo mundo, primeiro. 
Pesquisadora - E foi fácil?

Carla - Foi.

VÁRIAS VOZES - Mais ou menos.

Carla - Mais ou menos.

Keyla - Porque rolou briga...

Pesquisadora - E por que rola briga?

Keyla - Ah, porque...

Leo - Eu acho...

Vítor - Porque as pessoas não se colocam no lugar do outro.

ALGUÉM FALA - Porque não há muitos acordos.

Keyla - Porque um fica xingando o outro...

João - Um quer mandar no outro.

Keyla - Aí, o outro quer ficar batendo, aí o outro pega e xinga, aí sugere a briga.

Pesquisadora - Vítor, e você acha que esse "não se colocar no lugar do outro" é que atrapalha?

Vítor - É, eu acho que sim, né? Porque você tem que se colocar no lugar dele...

Vanir - Ah, porque pra o negócio poder sair bom, pra sair tudo direitinho, precisa ter um trabalho em grupo, precisa todo mundo ser unido, pra poder sair bem feito. [...] a gente precisa se colocar no lugar do outro, como a gente falou do Leo, tá entendendo?

\section{Ao serem questionados sobre o que eles aprenderam com a oficina:}

Vanir - E aprendi também a... Pra fazer amizade, a gente tem que compreender uns aos outros.

Leo - É... Eu acho que no final eu aprendi a ouvir mais as pessoas, por isso elas estão reclamando bastante disso... Só que eu sou muito "perficionalista", eu gosto muito de fazer as coisas o mais... O melhor possível que eu consigo fazer. Então... Eu fui um pouco chato, com essa... Com essa questão. Mas eu acho que eu aprendi a ouvir mais os outros, depois da oficina.

Pesquisadora - Houve alguma coisa que vocês fizeram nessa oficina que vocês aproveitaram nas aulas de vocês de matemática, geografia, português?

Vanir - Eu levei... Não foi muito pra dentro... Não foi certamente pra dentro da sala de aula, mas foi, tipo assim, assistindo uma televisão, porque eu falei, pensei, como quando eu tava indo filmar, ali o cara teve que se posicionar, mais ou menos assim pra poder filmar. Ou pode ser que ele fez não sei quantos cortes, assim, ele deu um close, fechou... Algumas coisas assim.

Leo - Eu acho que o meu praticamente foi a mesma coisa que a Vanir, porque eu aprendi também esses negócios do ângulo, close, essas coisas assim. Foi bem legal.

Pesquisadora - Aí observa nos filmes que assiste.

Vanir - Aqui, a gente vê a experiência de pessoas com raciocínio diferente, aqui a gente aprendeu a ouvir, aí a gente levou isso pra dentro de sala, pra conviver com os amigos e professores. Na maioria das vezes.

As falas deles sugerem que a maior parte da aprendizagem ocorrida nessa experiência parece ter sido relacionada a atividades em grupo e à capacidade de empatia, habilidades que serão abordadas no capítulo seguinte. 


\section{Habilidades desenvolvidas na oficina de produção audiovisual}

Neste eixo de análise, apresento os protocolos de observação de habilidades manifestadas pelos alunos na oficina, tais como tomada de decisões, ampliação da capacidade de empatia, capacidade para trabalhar em equipe, planejar/cumprir tarefas, argumentação e transcodificação de linguagens, indicando possíveis relações entre as atividades realizadas, a aprendizagem da linguagem audiovisual e o desenvolvimento dessas habilidades.

O British Film Institute (2010) ancora seus materiais didáticos em relatos de alunos e professores sobre as aprendizagens conquistadas com o uso e produção de filmes. Esses relatos indicam que as atividades com cinema na escola apresentam como resultados principais a integração social dos participantes e o desenvolvimento de diferentes habilidades. Para os professores que coordenam esses projetos:

[...] as atividades de educação cinematográfica encorajaram alunos isolados ou insatisfeitos a participarem das atividades, aumentando sua confiança. Também oferece oportunidades para os alunos desenvolverem habilidades no ambiente de trabalho, habilidades técnicas e as "habilidades sociais" de trabalho em grupo e discussão. O filme também pode contribuir para objetivos mais amplos na área local, por exemplo, reduzindo o comportamento antissocial e incentivando a compreensão. ${ }^{71}$ (BFI, 2010, p. 8).

As competências e/ou habilidades que a integração do cinema na vida escolar desenvolve parecem ser bastante amplas e abarcar distintos aspectos, em especial os ligados à melhora nos relacionamentos interpessoais, ampliação da qualidade da literacia midiática, melhora na capacidade de atenção e concentração, ampliação de repertório cultural, interesse na participação cidadã, aumento de autoestima, entre outros.

Entre as pesquisas consultadas, a maior parte evidencia, como resultado das oficinas, o melhor relacionamento dos estudantes com os colegas, com os professores e com a escola (Dall'Agnol, 2015; Garbin, 2011; Pedrosa, 2012; Pires, 2014; Silva, 2017) além de "alfabetização" do olhar e aprendizagem da linguagem cinematográfica ou da arte em geral (Costa, 2014; Faria, 2011;

\footnotetext{
71 Tradução minha do original: "Many teachers have reported that film education activities have encouraged isolated or disaffected pupils to participate and has increased their confidence. It also provides opportunities for pupils to develop workplace skills, technical skills and the 'soft skills' of groupwork and discussion. Film can also contribute to wider objectives in the local area, for example by reducing antisocial behaviour and encouraging cultural understanding."
} 
Maurício, 2010; Pimentel, 2013; Silva, 2017). Alguns estudos indicam também ganhos relacionados à aprendizagem de conteúdos escolares (Sá, 2016; Silva, 2001). Esses resultados constituem um importante indicador do papel que pode ser desempenhado pela presença, estruturada e planejada, do audiovisual na escola. Mas há ainda poucas pesquisas que se debruçam sobre a produção e análise de registros sistemáticos do que efetivamente é aprendido pelos estudantes nessas atividades, mesmo porque é difícil construir instrumentos adequados e confiáveis que possibilitem avaliar essa aprendizagem empiricamente como, via de regra, é complicado produzir instrumentos de avaliação de aprendizagens em quaisquer contextos onde estas ocorrem.

Muitos educadores de hoje estão começando a reconhecer o valor da aprendizagem conectada, um conceito que descreve a aprendizagem informal dos alunos em atividades de interesse ou de amizade que envolvem a mídia digital. Ao sair, brincar e se divertir com as atividades da mídia digital em bibliotecas, museus e programas de pós-escola, as crianças e os jovens ganham importantes habilidades de resolução de problemas e criatividade (Ito, 2012). Os educadores de artes, em particular, estão começando a explorar seu papel no apoio às competências de alfabetização digital dos alunos. Esta é uma área relativamente nova de exploração no contexto da formação de professores. (Hobbs \& Moore, 2014, p. 32).

De um modo geral, os que acompanham projetos desse tipo pelo lado de dentro, como diretores/as de escola e professores/as, afirmam perceber ganhos significativos no desenvolvimento dos alunos que participam das atividades. Nesta pesquisa, isso também ocorreu. Duas professoras do ensino fundamental I e a diretora da escola, em entrevista concedida a mim durante o período em que estava observando a oficina, a avaliaram como sendo uma experiência "excelente" para os alunos, em diferentes aspectos do comportamento deles, indicando que percebem "uma diferença gritante no antes e depois":

[...] a autoestima deles melhora. Até os que se achavam, assim, incapazes em determinadas coisas, até os especiais. Eu acompanhei vários especiais, não só dessa turma, já tiveram turmas anteriores que tinham alunos especiais. [...] Teve um aluno que me chamou muito a atenção [...] [antes] ele nem conseguia falar direito. E conseguiu fazer uma propaganda antitabagismo. Eu falei: "Professor, como é que você conseguiu que esse menino..." Sabe? "Falar do jeito que...". Participou de tudo, desde o começo da criação da campanha antitabagismo, enfim. Excelente! Eu acho muito bom! Eles têm interesse em fazer, os pequenos têm interesse, a partir do $6^{\circ}$ ano têm, e é ótimo. Melhora muito! Até a parte das outras disciplinas, o cognitivo deles melhora, porque eu acho que a concentração, união mesmo, deles, delegar função, enfim, eu acho que é excelente pra uma série de coisas! (Professora Joana).

A professora Lúcia acha que eles se tornam "mais responsáveis", talvez devido a "um certo ar de profissionalização na coisa". Ela afirma que eles começam mais animados, curiosos, interessados e que até podem perder um 
pouco de entusiasmo quando a atividade perde um pouco o "glamour", mas depois "vão entrando num ritmo muito legal [...] e eu começo a observar um diferencial deles em termos de comportamento, em termos de responsabilidade, é notório [...] parece que aquilo dá uma serenidade neles, essa responsabilidade." Ela se diz impressionada com a mudança que observa neles, "parece que dá uma maturidade emocional também" (Professora Lúcia). Nas palavras da diretora da escola, Professora Ester:

\footnotetext{
Eles têm um crescimento muito bom, verbalmente, eles começam a se colocar de forma melhor, a autoestima deles melhora absurdamente. $O$ desenvolvimento melhora muito depois que eles começam a participar nessas oficinas. [...] quando tem algum aluno que a gente sente que está com algum problema, de entrosamento, de ficar lá no canto dele, a gente pede para o professor da oficina convidar. $\mathrm{E}$ esses alunos convidados, também é muito legal ver o desenvolvimento deles!
}

Esses relatos, assim como os mencionados no material didático do $\mathrm{BFI}$, sugerem que efetivamente há ganhos sociocognitivos entre os alunos envolvidos na produção de filmes na escola, mas é necessário que as pesquisas produzam evidências mais consistentes do que as impressões (válidas, sem dúvida!) manifestadas pelos observadores externos e pelos professores de audiovisual na escola, pois estes ainda não desenvolveram instrumentos para registro e avaliação das aprendizagens promovidas nesse contexto.

A pesquisa de Kearney \& Schuck (2005) se destaca entre as demais, pois os autores analisam 60 projetos em que os estudantes produziam vídeos digitais, identificados por eles de três modos, conforme seu uso: modo 1 ferramenta para facilitar a comunicação dos alunos de uma mensagem, ideia ou informação (65\% dos casos); modo 2 - ferramenta para melhorar a observação e análise de desempenho ou fenômenos dos alunos (23\% dos projetos); modo 3 - ferramenta para apoiar a reflexão dos alunos sobre sua própria aprendizagem (12\% dos casos). Os projetos foram observados e analisados por pesquisadores que visitaram as escolas em diferentes momentos dos projetos e compararam suas observações. Outros resultados evidentes na maioria dos casos observados neste estudo foram: desenvolvimento de habilidades de produção de filmes e da linguagem relacionada a essa tarefa; desenvolvimento de habilidades de alfabetização midiática, habilidades de comunicação e apresentação; habilidades metacognitivas e afetivas.

Confirmando as crenças dos professores, o estudo indicou que os alunos demonstraram níveis impressionantes de comportamento autônomo, engajamento e motivação, e os dados sustentam a alegação de que os alunos 
estavam envolvidos e motivados durante a produção de seus vídeos. Kearney \& Schuck (2005) afirmam que os projetos estimulam a criatividade dos participantes, o que parece contrastar com muitas tarefas de aula tradicionais baseadas em papel (conforme relataram os alunos) e podem ajudar a explicar por que muitos estudantes relataram como esse tipo de trabalho se contrapõe às suas experiências em aulas comuns.

Com base na revisão de estudos empíricos, elaborei um protocolo de observação e registro de atitudes manifestadas pelos alunos participantes das oficinas, com foco especialmente em habilidades sociocognitivas, pois são estas as mais comumente relatadas por pesquisadores desse campo. Busquei registrar manifestações que indicassem, ou indiciassem, a aquisição ou ampliação da capacidade de trabalho em equipe, capacidade de empatia, de argumentação, de planejamento e organização de tarefas em prazos predeterminados e também de habilidades específicas relacionadas à aprendizagem da linguagem audiovisual, como de transcodificação de linguagens e de aplicação dos conceitos intrínsecos à gramática audiovisual.

Durante as observações da oficina, registrei as ocorrências dessas atitudes em alunos escolhidos, aleatoriamente, em cada turma. No protocolo, indiquei a frequência com que o(a) aluno(a) escolhido(a) demonstrava a atitude observada, e a intensidade em que esta ocorria, com base em uma escala Likert de 0 a 5: 0 - nada; 1 - muito pouco; 2 - pouco; 3 - dentro do esperado; 4 - um pouco mais que o esperado; 5 - superou as expectativas.

Foram preenchidos 54 protocolos de observação. Para o tratamento dos dados resultantes desse protocolo, estes foram inseridos no programa Atlas.ti, buscando identificar as recorrências e estabelecer correlações entre estas e as atividades realizadas no dia em que foram registradas. Considerei todos os protocolos preenchidos, levando em conta os registros realizados em todas as turmas, inclusive a de desistentes.

Para identificar a frequência de aparecimento dos indícios de cada habilidade, considerei as atitudes registradas no protocolo, sem levar em conta, no primeiro momento, a intensidade. Assim, mesmo considerando, por exemplo, que em determinado dia uma aluna demonstrou intensidade 5 de participação em atividades em grupos, para essa primeira análise considerei que a atitude foi registrada naquele dia para aquela aluna, contando apenas uma vez. Sendo assim, os totais indicam quantas vezes determinada habilidade foi registrada em todos os protocolos analisados. 
Atitudes relacionadas a: trabalhar em equipe, capacidade de empatia e capacidade de argumentação foram observadas tanto nas turmas desistentes como na turma final. As atitudes referentes à capacidade de planejamento, organização, transcodificação de linguagens e as habilidades estéticas tiveram pouca recorrência:

\begin{tabular}{|l|c|c|}
\hline \multicolumn{1}{|c|}{ Conjunto de habilidades } & Turma desistente & Turma final \\
\hline Trabalhar em equipe & 26 & 69 \\
Capacidade de empatia & 25 & 45 \\
Capacidade de planejamento & 0 & 1 \\
Capacidade de organização & 0 & 3 \\
Capacidade de argumentação & 24 & 27 \\
Transcodificação de linguagens & 1 & 3 \\
Habilidades estéticas & 0 & 4 \\
\hline
\end{tabular}

Quadro 10 - Habilidades elencadas por tipo de turmas Fonte: Elaboração própria.

Apresento nesse quadro as recorrências das turmas desistentes, para indicar que determinadas atitudes foram manifestadas desde o início da oficina, mas continuaram ocorrendo em maior frequência e adquiriram maior intensidade, em alguns casos, até o término do ano, mesmo com um número menor de alunos observados, se considerarmos que de 5 turmas iniciais, observei apenas uma a partir de agosto, pois as demais foram desistindo. Ao considerarmos que apenas uma turma chegou às gravações propriamente ditas do vídeo, seria de se esperar que essa turma tivesse demonstrado atitudes que indicassem 0 desenvolvimento de habilidades estéticas relacionadas à linguagem audiovisual, mas apenas um aluno manifestou atitudes que sugerem ganhos significativos nessa área, conforme abordarei mais à frente.

Para aprofundamento da análise, defini como códigos de análise no Atlas.ti as habilidades descritas no protocolo, gerando 24 códigos, o que mostra que das 36 atitudes observadas, 24 foram demonstradas pelos alunos pelo menos uma vez.

Vale lembrar que esta análise está baseada no conceito de cognição distribuída (Cole \& Engeström, 1998) e na teoria sócio-histórico-cultural de Vygotsky e, portanto, as habilidades manifestadas pelos estudantes na oficina de vídeo e o desenvolvimento destas devem ser consideradas como uma aprendizagem do grupo, uma vez que foi promovida na troca entre os participantes, mediada pelo professor. Dessa forma, é necessário olhar as recorrências das atitudes por aluno inicialmente para visualizarmos como cada atitude foi recorrente no grupo, indicando que houve ou não aprendizagem. 
No quadro a seguir, apresento a análise referente aos protocolos da turma que participou da oficina como um todo e, mais especificamente, dos estudantes que tiveram pelo menos 4 protocolos registrados, pois aqueles com número de protocolos inferior a 4 acabaram desistindo da oficina. Os totais indicados a seguir também mostram a frequência em que cada atitude ocorreu, tendo como base seu registro em todos os protocolos.

\begin{tabular}{|c|c|}
\hline Habilidades & \multirow{2}{*}{$\begin{array}{l}\text { Recorrências } \\
\text { (turma final) }\end{array}$} \\
\hline Trabalhar em equipe e realização/cumprimento/resolução de tarefa conjunta & \\
\hline Participou das atividades em grupo & 28 \\
\hline Negociou opiniões entre os participantes & 6 \\
\hline Propôs soluções para problemas que venham a surgir & 7 \\
\hline Tomou parte das decisões & 10 \\
\hline Manteve os acordos & 5 \\
\hline Demonstrou postura de liderança & 9 \\
\hline Pediu opiniões dos colegas sobre alguma solução a tomar & 2 \\
\hline \multicolumn{2}{|l|}{ Capacidade de empatia } \\
\hline Manteve postura atenta em relação ao outro & 31 \\
\hline Demonstrou que compreende o outro & 9 \\
\hline Mediou um conflito entre os participantes & 3 \\
\hline \multicolumn{2}{|l|}{ Capacidade de planejamento de atividades/tarefas - médio e longo prazos } \\
\hline Organizou atividades atento aos prazos & 1 \\
\hline Previu possíveis problemas e soluções para o que foi planejado & 0 \\
\hline Distribuiu tarefas & 0 \\
\hline Cumpriu as tarefas no prazo & 0 \\
\hline \multicolumn{2}{|l|}{ Capacidade de organização de tarefas em diferentes etapas } \\
\hline Ordenou tarefas conforme sua importância para o trabalho final & 0 \\
\hline Selecionou participantes conforme as habilidades de cada um para a tarefa & 1 \\
\hline Acompanhou as atividades e seu cumprimento em suas diferentes etapas & 0 \\
\hline Mudou de planos em caso de não atendimento das tarefas conforme planejado & 0 \\
\hline Atribuiu tarefas para todos & 1 \\
\hline \multicolumn{2}{|l|}{ Capacidade de argumentação } \\
\hline Expressou uma ideia com clareza para o outro & 18 \\
\hline Defendeu uma proposta com argumentos que justifiquem seu ponto de vista & 5 \\
\hline Mudou o argumento em defesa de uma mesma ideia & 1 \\
\hline Incorporou sugestões ao argumento original & 3 \\
\hline \multicolumn{2}{|l|}{ Capacidade de transcodificação de linguagens } \\
\hline Escreveu uma cena a partir de um argumento & 1 \\
\hline Indicou como encenar determinado texto escrito & 1 \\
\hline Indicou como filmar o que será encenado & 1 \\
\hline Indicou como editar o que foi filmado & 0 \\
\hline Indicou como demonstrar passagem de tempo & 0 \\
\hline Compreendeu a mudança de ordem entre o roteiro e o que está sendo filmado & 0 \\
\hline Indicou música/som e/ou iluminação para impressões destacadas no roteiro & 0 \\
\hline \multicolumn{2}{|l|}{ Habilidades estéticas na produção audiovisual } \\
\hline Sugeriu mudanças no cenário para melhorar o enquadramento da cena & 1 \\
\hline Sugeriu posicionamento da câmera para melhorar enquadramento & 1 \\
\hline Sugeriu mudanças na iluminação & 0 \\
\hline Indicou figurinos ou tipos de maquiagem para melhor retratar a cena & 1 \\
\hline Sugeriu melhor posicionamento de atores e figurantes para as cenas & 1 \\
\hline Sugeriu mudanças para melhorar o som da filmagem & 0 \\
\hline
\end{tabular}

Quadro 11 - Atitudes da turma final de alunos com pelo menos 4 protocolos registrados

Fonte: Elaboração própria. 
Com base na frequência de ocorrências das atitudes indicadas, produzi, no Atlas.ti, uma nuvem de palavras que registra, graficamente, o maior número de ocorrências:

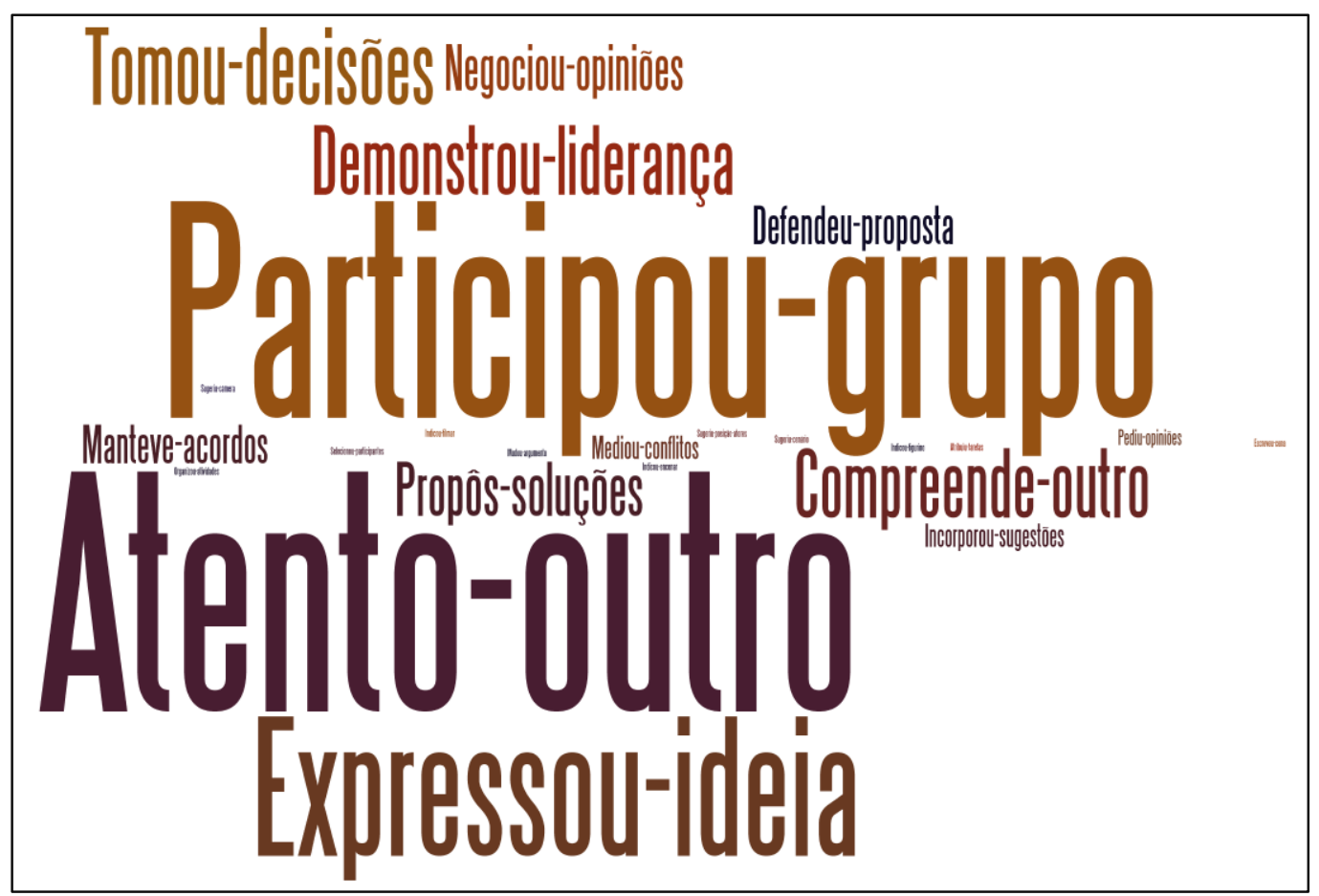

Figura 22 - Nuvem de atitudes observadas - todas as ocorrências Fonte: Elaboração própria.

Tais resultados confirmam o que as pesquisas na área apresentam sobre o quanto as oficinas de produção audiovisual em contextos educativos podem promover maior integração interpessoal entre os participantes por conta das atividades em grupo, estimulando a expressão de ideias e propiciando mais a prática coletiva e menos a formação de líderes.

Vale observar que as maiores recorrências são de atitudes relacionadas à participação em atividades em grupo e manutenção de postura atenta ao outro, as quais não necessariamente implicam postura mais ativa do aprendiz, mas indicam disponibilidade para a cooperação, o que é exigido em projetos desse tipo. Kearney \& Schuck (2005) indicam como resultado de pesquisa sobre alunos que produzem audiovisual, a evidente aprendizagem entre pares e em grupo em todos os casos observados, relacionando isso à própria natureza da produção cinematográfica.

A atitude de expressar uma ideia com clareza para o outro aparece em seguida em quantidade de ocorrências, e esta exige uma postura mais ativa do sujeito, que precisa elaborar um pensamento para expressá-lo de maneira que os demais possam compreendê-lo. Há também bom número de recorrências de 
tomou parte das decisões, cuja emergência talvez se deva ao caráter eminentemente coletivo das atividades relacionadas à produção audiovisual.

Com menor recorrência, mas ainda presentes, cito: demonstrou postura de liderança, demonstrou que compreende o outro e propôs soluções para problemas que venham a surgir. Talvez essas sejam habilidades a serem melhor trabalhadas nesses contextos, pois dizem respeito à capacidade de liderar, identificar um problema e encontrar soluções, algo em que a escola ainda investe pouco. As atitudes: negociou opiniões entre os participantes, defendeu uma proposta e manteve os acordos aparecem com menor intensidade nos resultados, o que sugere que a autonomia e a participação ativa precisam ser mais intensamente estimuladas, mesmo em contexto onde essas atitudes são tidas como pressupostas. As demais atitudes observadas têm pouquíssimas recorrências e serão consideradas a partir de outro ângulo de análise.

Considerando todos os protocolos, relacionei as atitudes observadas com as atividades promovidas pelo professor durante a oficina. Os resultados são:

\begin{tabular}{|c|c|c|c|c|c|c|}
\hline $\begin{array}{l}\text { Momentos } \\
\text { Habilidades }\end{array}$ & $\begin{array}{l}\text { Definição } \\
\text { da história }\end{array}$ & Roteiro & $\begin{array}{c}\text { Distribuiçã } \\
\text { o de } \\
\text { tarefas }\end{array}$ & $\begin{array}{l}\text { Linguagem } \\
\text { Audiovisual }\end{array}$ & Gravações & $\begin{array}{c}\text { Totai } \\
\boldsymbol{s}\end{array}$ \\
\hline $\begin{array}{c}\text { Trabalhar em } \\
\text { equipe }\end{array}$ & 0 & 20 & 11 & 10 & 31 & 72 \\
\hline Empatia & 0 & 12 & 5 & 4 & 20 & 41 \\
\hline Planejamento & 0 & 1 & 0 & 0 & 0 & 1 \\
\hline Organização & 0 & 1 & 1 & 1 & 1 & 4 \\
\hline Argumentação & 0 & 11 & 4 & 4 & 9 & 28 \\
\hline $\begin{array}{c}\text { Transcodificaç } \\
\text { ão de } \\
\text { linguagens }\end{array}$ & 0 & 1 & 0 & 0 & 2 & 3 \\
\hline $\begin{array}{c}\text { Habilidades } \\
\text { estéticas }\end{array}$ & 0 & 0 & 1 & 1 & 3 & 5 \\
\hline Totais & 0 & 46 & 22 & 20 & 66 & \\
\hline
\end{tabular}

Quadro 12 - Atitudes observadas relacionadas ao momento da oficina Fonte: Elaboração própria.

As correlações indicam que o maior número de atitudes registradas está relacionado à habilidade de trabalhar em equipe, seguida da capacidade de empatia e de argumentação. As demais tiveram poucas recorrências. Em relação ao momento da oficina em que essas habilidades se manifestam com mais intensidade, o período referente às gravações concentra o maior número de atitudes, seguido da escrita do roteiro. 
Vale destacar que no momento referente à definição da história, não há registro de ocorrência de nenhuma das atitudes observadas. Essa parte da oficina ocorreu logo no início do ano, entre abril e maio, e os protocolos registrados nesse período foram referentes a alunos que, posteriormente, vieram a desistir de participar da oficina. Isso pode ser um indicador de que a metodologia adotada pelo professor nessa primeira etapa da oficina pode não estar atendendo aos objetivos esperados e pode estar desestimulando a permanência dos alunos.

É importante destacar, ainda, que durante a construção do roteiro foram criadas várias oportunidades para que os alunos formulassem argumentos em defesa de suas ideias e propostas e para que houvesse discussões entre eles e com o professor sobre a maneira como as ações deveriam ocorrer no filme. Além disso, era necessário que houvesse entrosamento dos estudantes em um trabalho de equipe para que a escrita fosse concluída e que alguns deles atuassem como líderes para assegurar a finalização do texto do roteiro. Nesse momento, além de participação em atividades em grupo, foram também recorrentes atitudes que indicavam tomada de decisões. As exigências relacionadas à gravação de imagens, dentro e fora da sala onde ocorreu a oficina e o modo como essas foram conduzidas, parece ter favorecido o aparecimento de habilidades de propor soluções, manter acordos e demonstrar liderança, porém com menor recorrência do que o esperado ou o desejável, uma vez que o professor acabou tendo que conduzir grande parte das atividades. $\mathrm{O}$ quadro a seguir mostra as habilidades recorrentes em cada um dos momentos mencionados:

\begin{tabular}{|ccccccc|}
\hline $\begin{array}{c}\text { Momentos } \\
\text { Atitudes }\end{array}$ & Roteiro & $\begin{array}{c}\text { Distribuiçã } \\
\text { o de } \\
\text { tarefas }\end{array}$ & $\begin{array}{c}\text { Linguagem } \\
\text { Audiovisual }\end{array}$ & Gravações & $\begin{array}{c}\text { Totai } \\
\boldsymbol{S}\end{array}$ \\
Participou grupo & 8 & 3 & 2 & 14 & $\mathbf{2 7}$ \\
Negociou opiniões & 2 & 3 & 3 & 1 & $\mathbf{9}$ \\
Propôs soluções & 2 & 1 & 1 & 4 & $\mathbf{8}$ \\
Tomou decisões & 5 & 1 & 1 & 3 & $\mathbf{1 0}$ \\
Manteve acordos & 0 & 0 & 0 & 4 & $\mathbf{4}$ \\
Demonstrou liderança & 3 & 2 & 2 & 4 & $\mathbf{1 1}$ \\
Pediu opiniões & 0 & 1 & 1 & 1 & $\mathbf{3}$ \\
Totais & $\mathbf{2 0}$ & $\mathbf{1 1}$ & $\mathbf{1 0}$ & $\mathbf{3 1}$ & \\
\hline
\end{tabular}

Quadro 13 - Atitudes da habilidade trabalhar em equipe relacionadas ao momento da oficina

Fonte: Elaboração própria. 
As atitudes referentes à capacidade de empatia, segunda habilidade com maior número de registros, também foram mais presentes nas atividades relacionadas à escrita do roteiro (12 ocorrências) e durante as gravações (20 ocorrências), distribuídas da seguinte maneira:

\begin{tabular}{|cccccc|}
\hline $\begin{array}{c}\text { Momentos } \\
\text { Atitudes }\end{array}$ & Roteiro & $\begin{array}{c}\text { Distribuiçã } \\
\text { o de } \\
\text { tarefas }\end{array}$ & $\begin{array}{c}\text { Linguagem } \\
\text { Audiovisual }\end{array}$ & Gravações & $\begin{array}{c}\text { Totai } \\
\mathbf{s}\end{array}$ \\
$\begin{array}{c}\text { Manteve postura } \\
\text { atenta ao outro }\end{array}$ & 10 & 3 & 2 & 14 & $\mathbf{2 9}$ \\
$\begin{array}{c}\text { Demonstrou } \\
\text { compreender o outro }\end{array}$ & 1 & 1 & 1 & 5 & $\mathbf{8}$ \\
$\begin{array}{c}\text { Mediou conflito } \\
\text { Totais }\end{array}$ & 1 & 1 & 1 & 1 & $\mathbf{4}$ \\
\hline
\end{tabular}

Quadro 14 - Atitudes da capacidade de empatia relacionadas ao momento da oficina

Fonte: Elaboração própria.

A atitude mais registrada foi manter postura atenta em relação ao outro. Outra atitude observada, mas menos recorrente foi demonstrar que compreende o outro, mais presente durante as gravações. A mediação de conflitos entre os participantes esteve presente, porém com menor recorrência, mantendo-se assim em todos os momentos da oficina.

Contrariamente ao esperado, a habilidade com menor número de registros foi a de argumentação, cujas atitudes indiciárias também foram observadas durante a construção do roteiro (11 ocorrências) e a realização das gravações ( 9 ocorrências), especificado no quadro a seguir:

\begin{tabular}{|cccccc|}
\hline $\begin{array}{c}\text { Momentos } \\
\text { Atitudes }\end{array}$ & Roteiro & $\begin{array}{c}\text { Distribuiçã } \\
\text { o de } \\
\text { tarefas }\end{array}$ & $\begin{array}{c}\text { Linguagem } \\
\text { Audiovisual }\end{array}$ & Gravações & $\begin{array}{c}\text { Totai } \\
\boldsymbol{s}\end{array}$ \\
Expressou ideia & 8 & 2 & 2 & 6 & $\mathbf{1 8}$ \\
Defendeu proposta & 1 & 1 & 1 & 2 & $\mathbf{5}$ \\
Mudou argumento & 1 & 0 & 0 & 0 & $\mathbf{1}$ \\
Incorporou sugestões & 1 & 1 & 1 & 1 & $\mathbf{4}$ \\
Totais & $\mathbf{1 1}$ & $\mathbf{4}$ & $\mathbf{4}$ & $\mathbf{9}$ & \\
\hline
\end{tabular}

Quadro 15 - Atitudes da capacidade de argumentação relacionadas ao momento da oficina Fonte: Elaboração própria.

A análise dos registros indica que as atitudes desenvolvidas nesta oficina se concentraram com maior frequência durante a construção do roteiro e as gravações, momentos em que os alunos precisavam estar bastante conectados entre eles e concentrados nas tarefas propostas pelo professor. Talvez tenha 
faltado um maior estímulo à autonomia dos alunos, o que os obrigaria a defender suas ideias e propostas de soluções perante os colegas e a modificar suas ideias face aos argumentos do outro.

A partir desses resultados, apresento a seguir os registros das habilidades por aluno observado. Foram selecionados apenas os alunos que tiveram pelo menos 4 protocolos preenchidos, para que fosse possível perceber uma progressão/continuidade das habilidades apresentadas por eles do início ao fim da oficina. Como a observação individual era feita com base na intensidade das atitudes apresentadas naquele dia (0 - nada; 1 - muito pouco; 2 - pouco; 3 dentro do esperado; 4 - um pouco mais que o esperado; 5 - superou as expectativas), organizei esse registro por cores específicas para cada habilidade, aumentando a intensidade da cor, conforme a intensidade da atitude observada, como traz o quadro seguinte:

\begin{tabular}{|c|c|c|c|c|c|c|}
\hline $\begin{array}{l}\text { Trabalhar em equipe e } \\
\text { realização/cumprimento/resolução } \\
\text { de tarefa conjunta }\end{array}$ & 0 & 1 & 2 & 3 & 4 & 5 \\
\hline Capacidade de empatia & 0 & 1 & 2 & 3 & 4 & 5 \\
\hline $\begin{array}{l}\text { Capacidade de planejamento de } \\
\text { atividades/tarefas para médio e } \\
\text { longo prazos }\end{array}$ & 0 & 1 & 2 & 3 & 4 & 5 \\
\hline $\begin{array}{l}\text { Capacidade de organização de } \\
\text { tarefas em diferentes etapas }\end{array}$ & 0 & 1 & 2 & 3 & 4 & 5 \\
\hline Capacidade de argumentação & 0 & 1 & 2 & 3 & 4 & 5 \\
\hline $\begin{array}{l}\text { Capacidade de transcodificação } \\
\text { de linguagens }\end{array}$ & 0 & 1 & 2 & 3 & 4 & 5 \\
\hline $\begin{array}{l}\text { Habilidades estéticas na } \\
\text { produção audiovisual }\end{array}$ & 0 & 1 & 2 & 3 & 4 & 5 \\
\hline
\end{tabular}

Quadro 16 - Recorrência das habilidades coloridas por intensidade Fonte: Elaboração própria.

Foram analisados os protocolos de 7 alunos, com registros realizados em 4 ou 5 visitas. Cada protocolo foi colorido conforme a recorrência das atitudes tomadas pelos estudantes, desconsiderando aquelas que não foram observadas. Os quadros mostram mais claramente como as atitudes observadas na oficina de produção audiovisual se restringem às habilidades de trabalho em equipe, capacidade de empatia e capacidade de argumentação. As respectivas atitudes indicadas como "dentro do esperado" e "um pouco mais que o esperado" relacionadas a tais habilidades são: participou das atividades, manteve postura atenta em relação ao outro e expressou uma ideia com clareza para o outro. 
O último quadro apresenta as atitudes que indiciam habilidades do aluno Leo, líder do grupo. Como "ponto fora da curva", as atitudes demonstradas por esse aluno foram tomadas na análise conjunta dos demais alunos, não como elemento de comparação, mas como uma diferença que poderia iluminar a análise das recorrências. Esse tema será retomado a seguir, ainda nesse capítulo.

\begin{tabular}{|c|c|c|c|c|c|c|}
\hline \multirow{2}{*}{ Habilidades } & \multirow{2}{*}{ Atitudes } & \multicolumn{5}{|c|}{ Protocolo } \\
\hline & & 19 & $2^{\circ}$ & 3은 & $4^{\circ}$ & 5은 \\
\hline \multirow{5}{*}{$\begin{array}{l}\text { Trabalho em } \\
\text { equipe }\end{array}$} & Participou das atividades em grupo & & 2 & 2 & 4 & 1 \\
\hline & Tomou parte das decisões & & 1 & & & \\
\hline & Manteve os acordos & & & & 2 & \\
\hline & Demonstrou postura de liderança & & & & 1 & \\
\hline & $\begin{array}{l}\text { Pediu opiniões dos colegas sobre solução a } \\
\text { tomar }\end{array}$ & & 1 & & & \\
\hline \multirow[t]{2}{*}{ Empatia } & Manteve postura atenta em relação ao outro & 2 & 2 & 3 & 2 & 1 \\
\hline & Demonstrou que compreende o outro & & & 1 & & \\
\hline Argumentação & Expressou uma ideia com clareza para o outro & & 3 & & & \\
\hline
\end{tabular}

Quadro 17 - Habilidades registradas - Carla

Fonte: Elaboração própria.

\begin{tabular}{|c|c|c|c|c|c|}
\hline Habilidades & Atitudes & \multicolumn{4}{|c|}{ Protocolo } \\
\hline \multirow{4}{*}{$\begin{array}{c}\text { Trabalho em } \\
\text { equipe }\end{array}$} & Participou das atividades em grupo & 1 & 3 & 4 & 1 \\
\hline & Propôs soluções para problemas que venham a surgir & & 1 & & \\
\hline & Tomou parte das decisões & & & & 1 \\
\hline & Demonstrou postura de liderança & & & & 1 \\
\hline \multirow{2}{*}{ Empatia } & Manteve postura atenta em relação ao outro & 2 & 2 & 2 & 1 \\
\hline & Demonstrou que compreende o outro & & & 1 & \\
\hline Argumentação & Expressou uma ideia com clareza para o outro & 2 & 3 & & 2 \\
\hline
\end{tabular}

Quadro 18 - Habilidades registradas - Igor

Fonte: Elaboração própria.

\begin{tabular}{|c|c|c|c|c|c|c|}
\hline Habilidades & Atitudes & & & toc & & \\
\hline \multirow{3}{*}{$\begin{array}{l}\text { Trabalho em } \\
\text { equipe }\end{array}$} & Participou das atividades em grupo & 1 & $\begin{array}{c}2^{2} \\
1\end{array}$ & $\begin{array}{l}30 \\
2\end{array}$ & $\begin{array}{c}4^{-} \\
4\end{array}$ & 3 \\
\hline & $\begin{array}{l}\text { Propôs soluções para problemas que venham a } \\
\text { surgir }\end{array}$ & 1 & 1 & & & 1 \\
\hline & Manteve os acordos & & & & 2 & \\
\hline \multirow{2}{*}{ Empatia } & Manteve postura atenta em relação ao outro & 2 & 1 & 3 & 2 & 1 \\
\hline & Demonstrou que compreende o outro & & & 1 & & 1 \\
\hline Argumentação & Expressou uma ideia com clareza para o outro & 2 & 1 & & & 1 \\
\hline
\end{tabular}

Quadro 19 - Habilidades registradas - João

Fonte: Elaboração própria. 


\begin{tabular}{|c|c|c|c|c|c|c|}
\hline \multirow{2}{*}{ Habilidades } & \multirow[t]{2}{*}{ Atitudes } & \multicolumn{5}{|c|}{ Protocolo } \\
\hline & & 10 & $2^{\circ}$ & 3o & 4우 & 5우 \\
\hline \multirow{6}{*}{$\begin{array}{l}\text { Trabalho em } \\
\text { equipe }\end{array}$} & Participou das atividades em grupo & & 3 & 2 & 4 & 2 \\
\hline & $\begin{array}{l}\text { Fez negociações entre as opiniões dos } \\
\text { participantes }\end{array}$ & & & 1 & & \\
\hline & Tomou parte das decisões & & 2 & & & \\
\hline & Manteve os acordos & & & & 2 & \\
\hline & Demonstrou postura de liderança & & 1 & 1 & & \\
\hline & $\begin{array}{l}\text { Pediu opiniões dos colegas sobre solução a } \\
\text { tomar }\end{array}$ & & & 2 & & \\
\hline \multirow{2}{*}{$\begin{array}{c}\text { Empatia } \\
\text { Argumentação }\end{array}$} & Manteve postura atenta em relação ao outro & 2 & 2 & 3 & 2 & 1 \\
\hline & Expressou uma ideia com clareza para o outro & & 2 & 1 & & \\
\hline
\end{tabular}

Quadro 20 - Habilidades registradas - Keyla

Fonte: Elaboração própria.

\begin{tabular}{|c|c|c|c|c|c|}
\hline Habilidades & Atitudes & 10 & & :olo & 10 \\
\hline \multirow{2}{*}{$\begin{array}{l}\text { Trabalho em } \\
\text { equipe }\end{array}$} & Participou das atividades em grupo & & 1 & 4 & 3 \\
\hline & Demonstrou postura de liderança & 1 & & & \\
\hline \multirow{2}{*}{ Empatia } & Manteve postura atenta em relação ao outro & 1 & 1 & 3 & 1 \\
\hline & Demonstrou que compreende o outro & & & & 2 \\
\hline Argumentação & Expressou uma ideia com clareza para o outro & 1 & & & 1 \\
\hline \multicolumn{6}{|c|}{$\begin{array}{l}\text { Quadro } 21 \text { - Habilidades registradas - Sueli } \\
\text { Fonte: Elaboração própria. }\end{array}$} \\
\hline Habilidades & Atitudes & 10 & & Colo & 10 \\
\hline \multirow{4}{*}{$\begin{array}{l}\text { Trabalho em } \\
\text { equipe }\end{array}$} & Participou das atividades em grupo & 3 & 1 & 3 & 1 \\
\hline & Propôs soluções para problemas que venham a surgir & & & 1 & \\
\hline & Tomou parte das decisões & 2 & & & \\
\hline & Manteve os acordos & 1 & & & \\
\hline \multirow[t]{2}{*}{ Empatia } & Manteve postura atenta em relação ao outro & 2 & 1 & 1 & 1 \\
\hline & Demonstrou que compreende o outro & 2 & & 1 & \\
\hline \multirow{2}{*}{ Argumentação } & Expressou uma ideia com clareza para o outro & 3 & 2 & 1 & \\
\hline & Defendeu uma proposta & 1 & & & \\
\hline
\end{tabular}

Quadro 22 - Habilidades registradas - Vítor

Fonte: Elaboração própria. 


\begin{tabular}{|c|c|c|c|c|c|}
\hline \multirow{2}{*}{ Habilidades } & \multirow{2}{*}{ Atitudes } & \multicolumn{4}{|c|}{ Protocolo } \\
\hline & & 10 & $2^{\circ}$ & 3음 & $4^{\circ}$ \\
\hline \multirow{7}{*}{ Trabalho em equipe } & Participou das atividades em grupo & 3 & 3 & 4 & 1 \\
\hline & Fez negociações entre as opiniões dos participantes & 2 & 3 & & 1 \\
\hline & $\begin{array}{l}\text { Propôs soluções para problemas que venham a } \\
\text { surgir }\end{array}$ & 1 & 2 & 2 & 1 \\
\hline & Tomou parte das decisões & 3 & 3 & 3 & 2 \\
\hline & Manteve os acordos & & & 2 & \\
\hline & Demonstrou postura de liderança & 4 & 4 & 2 & 1 \\
\hline & $\begin{array}{l}\text { Pediu opiniões dos colegas sobre alguma solução a } \\
\text { tomar }\end{array}$ & & 3 & & 1 \\
\hline \multirow{3}{*}{ Empatia } & Manteve postura atenta em relação ao outro & 3 & 4 & 2 & 2 \\
\hline & Demonstrou que compreende o outro & 3 & 4 & & 1 \\
\hline & Mediou um conflito entre os participantes & 1 & 2 & & 1 \\
\hline \multirow{2}{*}{ Planejamento } & Organizou atividades atento aos prazos & 1 & & & \\
\hline & Previu possíveis problemas e soluções & & 1 & & \\
\hline \multirow{2}{*}{ Organização } & Selecionou part. por habilidades para a tarefa & & 1 & & \\
\hline & Atribuiu tarefas para todos & & & 2 & \\
\hline \multirow{4}{*}{ Argumentação } & Expressou uma ideia com clareza para o outro & 4 & 4 & 2 & 2 \\
\hline & Defendeu uma proposta & 3 & 3 & 1 & 1 \\
\hline & Mudou o argumento em defesa de uma ideia & 1 & & & \\
\hline & Incorporou sugestões ao argumento original & 3 & 3 & & 1 \\
\hline \multirow{3}{*}{$\begin{array}{l}\text { Transcodificação } \\
\text { de linguagens }\end{array}$} & Escreveu uma cena a partir de um argumento & 5 & & & \\
\hline & Indicou como encenar determinado texto escrito & & & 5 & 2 \\
\hline & Indicou como filmar o que será encenado & & & 1 & \\
\hline \multirow{4}{*}{$\begin{array}{l}\text { Habilidades } \\
\text { estéticas }\end{array}$} & Sugeriu mudanças no cenário & & & 1 & \\
\hline & Sugeriu posicionamento da câmera & & & 1 & \\
\hline & Indicou figurinos ou tipos de maquiagem & & 1 & & \\
\hline & $\begin{array}{l}\text { Sugeriu melhor posicionamento de atores e } \\
\text { figurantes }\end{array}$ & & & 2 & \\
\hline
\end{tabular}

Quadro 23 - Habilidades registradas - Leo

Fonte: Elaboração própria.

Ao retomar as informações apresentadas no Quadro 10 sobre atitudes observadas relacionadas ao momento da oficina, é possível verificar a pequena frequência de atitudes relacionadas às habilidades de planejamento de atividades, capacidade de organização, transcodificação de linguagens e habilidades estéticas envolvidas na produção audiovisual. Após observar os quadros de habilidades por alunos, fica claro que, dos estudantes com mais de 4 protocolos analisados, apenas Leo apresentou atitudes referentes a estas habilidades, indicadas como pouco recorrentes entre os demais. Para compreender esse caso, é preciso retomar algumas informações importantes sobre Leo, algumas mencionadas na apresentação dele.

Leo parecia ser um aluno diferenciado dos demais estudantes da escola onde foi realizada a pesquisa. Usava mochila, tênis e moletons mais novos e que pareciam ser mais caros do que os dos colegas. Tinha um bom smartphone e 
sempre era requisitado pelos colegas para rotear sua internet móvel, o que ele fazia sem problemas. Nenhuma vez o vi dirigir-se ao refeitório da escola para comer a merenda, o que indica que, provavelmente, ele preferia comer em casa. Algumas vezes o vi comprando lanche ou doce em uma banquinha na frente da escola. Percebi que ele não permanecia na escola para a aula da tarde, sem ir em casa, como os demais alunos da oficina, pois o pai sempre vinha pegá-lo ao meio-dia de carro e provavelmente o trazia de volta para sua aula à tarde. Pelo que conversei com ele e o que seus colegas comentavam, Leo e sua família haviam se mudado recentemente para o Rio de Janeiro por demanda profissional de seu pai e aquele era seu primeiro ano nessa escola. Embora fosse um aluno novato, Leo era um líder na escola pelo seu relacionamento com os colegas. Articulava muito bem as palavras, seu vocabulário era mais amplo que o dos demais e era bastante falante - as garotas da turma por vezes se mostravam entediadas com seu falatório.

A atuação mais participativa de Leo em relação aos demais alunos fez com que ele se destacasse, porém, algumas alunas que também demonstraram postura de liderança (Keyla e Carla) tinham embates frequentes com ele ou ficavam quietas demais nas aulas em que ele comandava as atividades, demonstrando, dessa forma, descontentamento. O professor logo percebeu o quanto algumas tarefas, como a escrita do roteiro, eram cumpridas apenas quando Leo estava na oficina e isso fez com que suas expectativas em relação à liderança da turma ficassem focadas nele, sem talvez se dar conta de que outros alunos poderiam também exercer esse papel. Leo sempre que estava presente participava da aula e foi ele quem mais contribuiu para a construção da história e escrita do roteiro. O diário de campo de uma das aulas de escrita do roteiro traz um resumo de como se dava a relação entre os participantes da oficina:

Durante a escrita, Leo medeia os conflitos entre os colegas sobre o texto. Leandra só levanta a cabeça quando algo errado acontece. Logo depois, ela volta a baixar a cabeça e a escrever no caderno. Mesmo calada, ela participa das atividades e escreve as características dos personagens em seu caderno.

Enquanto Leo escreve o roteiro no computador, os demais indicam coisas que ele deve mudar quanto à história ou à escrita do texto.

[...] Em um momento, Keyla se distrai com celular e Leo reclama que ela não está ajudando e fica jogando:

Leo: A gente tá no dia dois. De três dias, a gente já tá no dia dois.

Keyla: Caraca!

Leo: Enquanto você está jogando no seu telefone, a gente já tá aqui...

[...] Foi visível como a participação de Leo hoje adiantou a escrita do roteiro dessa turma. (Diário de campo - visita 8.2). 
A maneira como ele argumenta, defende sua opinião, lidera, chama para a participação, reclama da falta de atenção da colega, escuta, acolhe ou contesta a opinião e sugestão dos demais participantes indica o quanto estão desenvolvidas suas habilidades de trabalho em equipe, empatia, organização, planejamento e argumentação.

Quando percebi sua intensa participação na oficina, inclusive usando termos específicos da linguagem cinematográfica nas discussões com o professor, perguntei se ele já havia feito oficina de produção audiovisual antes, em outra escola; Leo respondeu que estava fazendo, naquele ano, um curso de edição de vídeo. Nesta aula, Leo respondeu várias perguntas feitas pelo professor durante a apresentação de um vídeo que tratava da sintaxe da narrativa audiovisual, mostrando tipos de enquadramento, planos, movimento e ângulos de câmera, movimento de lente e sensações psicológicas cineasta pode passar com o filme, entre outros aspectos, usando, por vezes, termos próprios dessa linguagem:

Professor Jonas: Qual esse plano?

Leo: Americano.

Jonas: Não precisa ser de frente, é um enquadramento mais aberto e o importante é pensar que ele vai da coxa pra cima.

Leo: Então pode ser um plano geral?

Jonas: Pode ser um plano geral, mas como tem alguém na frente e ele é o nosso personagem...

$[\ldots]$

O vídeo que apresenta alguns ângulos de câmera, fala do ângulo da câmera "plongé". O professor mostra com o celular dele essa posição. Leo comenta:

Leo: Tem o de baixo para cima também.

Jonas: [mostrando com seu celular] É. Esse é o plongé e esse aqui é o contraplongé: de baixo pra cima.

Quando eles falavam de movimentos de câmera a partir do vídeo:

Leo: Eu vi numa série, um plano geral que pra conseguir, tipo, se tinha uma fazenda enorme e queria saber como era, tipo fazer um mapa, aí você contratava um helicóptero e ele subia e fazia um mapeamento da área e tudo.

$[\ldots]$

Jonas: Os celulares têm a lente muito pequena e fazem o que a gente chama de zoom digital.

Leo: [fala junto com o professor] Digital. Mas agora tão tendo uns celulares que tem duas câmeras que tem o zoom óptico.

Jonas: Exatamente.

$[\ldots]$

Jonas: Mas é difícil fazer um plano sequência? Vocês acham? 
Carla: Eu acho que não.

Jonas: Ou é fácil?

Leo: Eu acho que é mais difícil.

Jonas: Por quê?

Leo: Porque você tem que ir seguindo a pessoa e você também tem que ir virando o ângulo pra conseguir virar melhor. Porque, olha, ele estava vindo atrás dela. Agora ele já tá vindo pro lado dela, pra conseguir... Porque se você tiver estivesse vindo reto, você não ia conseguir ver bem o que tinha naquela área ali. E é mais difícil porque você tem que ir seguindo a pessoa. (Diário de campo - visita 14).

A experiência do curso de edição talvez tenha contribuído para que ele demonstrasse atitudes que indicam habilidade de transcodificação de linguagens e habilidades estéticas relacionadas ao audiovisual. Estas últimas foram pouco recorrentes entre os demais, mas mesmo assim apareceram em algumas observações, o que demonstra que poderiam ter sido mais exploradas, caso houvesse maiores possibilidades para isso.

O quadro de habilidades de Leo se mostra como o resultado esperado para uma oficina de produção audiovisual na escola. Sabemos que há um conjunto de fatores associados ao desenvolvimento de habilidades especificamente relacionadas à aquisição da linguagem audiovisual, entre eles, o acesso regular a diferentes tipos de filmes. Os resultados evidenciados na análise do protocolo de observação de suas atitudes nesse contexto de aprendizagem parecem indicar que estas não foram desenvolvidas totalmente nessa oficina, mas talvez possam ter sido ampliadas ali, em razão do protagonismo que ele assumiu.

Não se trata de estabelecer comparações, mas de tomar o protocolo de observação das atitudes manifestadas por esse menino, ao longo desse processo, como possível fonte para o estabelecimento de objetivos que poderiam nortear oficinas desse tipo, com relação a todos os participantes. A análise dos protocolos relacionados às habilidades demonstradas pelos demais alunos, individualmente, apontam que a oficina não conseguiu promover o desenvolvimento de todas as habilidades factíveis de serem desenvolvidas nesses contextos de aprendizagem. Na oficina, Leo teve oportunidade de exercitar suas habilidades sociocognitivas, pois ele participava com mais desenvoltura que os demais, até porque era estimulado pelo professor para isso (algumas vezes o professor reclamou com Leo por ele ter faltado, comentando que sem ele a escrita do roteiro não andava).

As habilidades mais recorrentes entre os demais alunos (trabalho em equipe, empatia e argumentação) respondem diretamente ao objetivo do 
professor, de desenvolver a expressão dos alunos através da escrita, conforme abordei no capítulo de análise de sua pedagogia. Portanto, essa oficina cumpre os objetivos que ele estabeleceu para seu trabalho e promove o desenvolvimento dos alunos em relação a essas habilidades.

É possível supor que uma oficina de produção audiovisual com pressupostos teórico-metodológicos orientados também para o desenvolvimento de habilidades sociocognitivas, além da aquisição de habilidades especificamente relacionadas à linguagem audiovisual, pode contribuir para a formação dos alunos em questões relacionadas ao relacionamento interpessoal, à interação social, à literacia midiática, autonomia, cidadania, formação estética, entre outras.

Com esta modelagem analítica, abordei alguns aspectos importantes que envolvem a produção audiovisual na escola buscando ir além das crenças e percepções sobre essas práticas, que por sua ampliação e frequência nas escolas exigem cada vez mais um olhar mais aprofundado sobre seus pressupostos, objetivos e aprendizagens promovidas. Acredito que isso ajuda a fortalecer esse campo na área de educação, deixando de olhar o audiovisual/cinema como a "(eterna) maneira inovadora" de trabalhar determinados temas na escola ou como uma "isca" para chamar a atenção dos alunos. 


\section{8 \\ Considerações finais}

A pesquisa aqui apresentada teve o objetivo geral de descrever e analisar o processo de ensino-aprendizagem da linguagem audiovisual em uma escola pública da rede de ensino municipal do Rio de Janeiro, identificando quais conhecimentos e habilidades desenvolvidas pelos estudantes que participaram de uma oficina de produção audiovisual durante o ano de 2017. Para alcançar esse objetivo, foi necessário: identificar, descrever e analisar a pedagogia e procedimentos adotados pelo professor da oficina, em busca de compreender quais pressupostos teórico-metodológicos subsidiavam sua pedagogia audiovisual; e identificar a emergência, no grupo de estudantes, de habilidades sociocognitivas (como gestão de projeto, tomada de decisão, planejamento e organização de tarefas, trabalho em equipe, argumentação, empatia e transcodificação de linguagens, entre outras), mobilizadas no processo de criação de filmes. Esses objetivos nortearam a construção de argumentos para a defesa da tese de que a produção audiovisual na escola promove habilidades sociocognitivas.

Na revisão de literatura, abordei como o cinema na escola ainda figura, na maioria dos projetos, de maneira instrumental, ou seja, como um suporte para ajudar na aprendizagem de determinado conteúdo ou como uma mídia, algo que tem sua validade, dependendo dos objetivos e contextos em que se inserem essas propostas (Hobbs \& Moore, 2014; Kearney \& Schuck, 2005). As pesquisas consideram a produção audiovisual na escola como estimulante/motivadora, sendo um importante espaço para desenvolvimento da linguagem e contato com a arte, formação cidadã e desenvolvimento da capacidade crítica dos alunos. Além disso, ver/fazer filmes na escola também serve de apoio aos professores que se mostram interessados em renovar suas práticas ou buscar estímulos para ensinar.

A análise dessas pesquisas demonstrou que as práticas desenvolvidas em oficinas de vídeo na escola seguem linhas teóricas distintas, a partir das quais foi possível desenvolver o conceito de pedagogia audiovisual. Foi possível distinguir duas vertentes que orientam as pesquisas nesse tema e servem de base para a construção e promoção e oficinas de cinema na escola, a saber: cinemaeducação, que entende o cinema como arte e o fazer cinema como um gesto de criação (Bergala, 2008; Fresquet, 2013; Migliorin, 2011; Norton, 2013); e mídia- 
educação, a partir de estudos que buscam alfabetizar o olhar e formar para as mídias (Fantin, 2014; Kearney \& Schuck, 2005; Pires, 2010). Essas perspectivas compartilham visões muito próximas sobre os lugares e atuações dos participantes nas oficinas (horizontalidade na relação professor-aluno, trabalho em grupo, criação dos alunos, etc.), porém, suas propostas metodológicas se diferenciam um pouco, devido ao direcionamento teórico que perseguem.

As observações registradas no trabalho de campo me ajudaram a descrever e analisar a proposta da oficina ministrada para alunos do segundo segmento do ensino fundamental. Para isso, usei as lentes da revisão teórica e elenquei as diversas etapas da oficina, analisando a pedagogia audiovisual do professor Jonas. Assim, cheguei à conclusão de que a oficina cumpriu o objetivo traçado pelo professor, que era permitir que os alunos experimentassem e vivenciassem o processo de criação de um filme com ênfase na produção textual. Sua prática demonstrou grande preocupação com a produção do roteiro, que tomou a maior parte da oficina e, por isso, destoa do que indicam as pedagogias audiovisuais aqui analisadas, pois, na metodologia adotada por esse professor, ver filmes e desempenhar diferentes tarefas na realização do vídeo são atividades consideradas de menor importância. A edição e a divulgação do filme não ocorreram pela falta de tempo hábil para finalizar todas as etapas, entre outras ações entendidas nesta tese como relevantes para o desenvolvimento desse tipo de trabalho na escola. Essas diferenças em relação às vertentes norteadoras da pedagogia audiovisual podem ser justificadas pelo ano atípico de trabalho, como indicou o professor - que realiza essa oficina há muitos anos nesta escola e em outras -, que resultou no abandono de alunos da oficina e na desmotivação dos que continuavam a frequentar as aulas e, muitas vezes, do próprio professor.

No início da oficina, a escolha da história e a criação do roteiro proporcionaram aos alunos um ambiente favorável à argumentação em defesa de suas histórias e ideias. Por ter sido um processo demorado, os estudantes tiveram várias oportunidades de discutir a construção de suas narrativas e de desenvolverem seus personagens, o que não aconteceu como o professor pretendia, tendo sido priorizada a escrita do roteiro, devido à falta de tempo.

Com uma turma menor foi possível desenvolver um trabalho em equipe mais forte, pois os estudantes precisavam estar coesamente envolvidos, demonstrar disponibilidade e versatilidade para resolver problemas e cumprir tarefas que nem sempre eram suas, pois ao longo do processo, a constante falta 
de outros participantes demandava dos estudantes atender demandas que não haviam sido atribuídas ou planejadas para eles anteriormente.

As capacidades de interação social têm na oficina de produção audiovisual na escola um campo fértil de trabalho, aberto para o desenvolvimento de inúmeras capacidades e habilidades sociocognitivas, promovidas pelas tarefas e trocas coletivas durante os diversos exercícios elaborados para a criação audiovisual. Mesmo com um número pequeno de alunos ao término do ano (em relação àqueles que estavam inscritos no início), registrei em protocolo as atitudes manifestadas pelos estudantes nas oficinas, tendo em vista habilidades relacionadas a trabalho em grupo, empatia, capacidade de argumentação, planejamento e organização de tarefas, transcodificação de linguagens e capacidades estéticas. A análise desses protocolos indicou que as atividades observadas promoveram a habilidades relacionadas a trabalho em equipe, empatia e capacidade de argumentação para a maioria dos alunos, sendo mais recorrentes as seguintes atitudes:

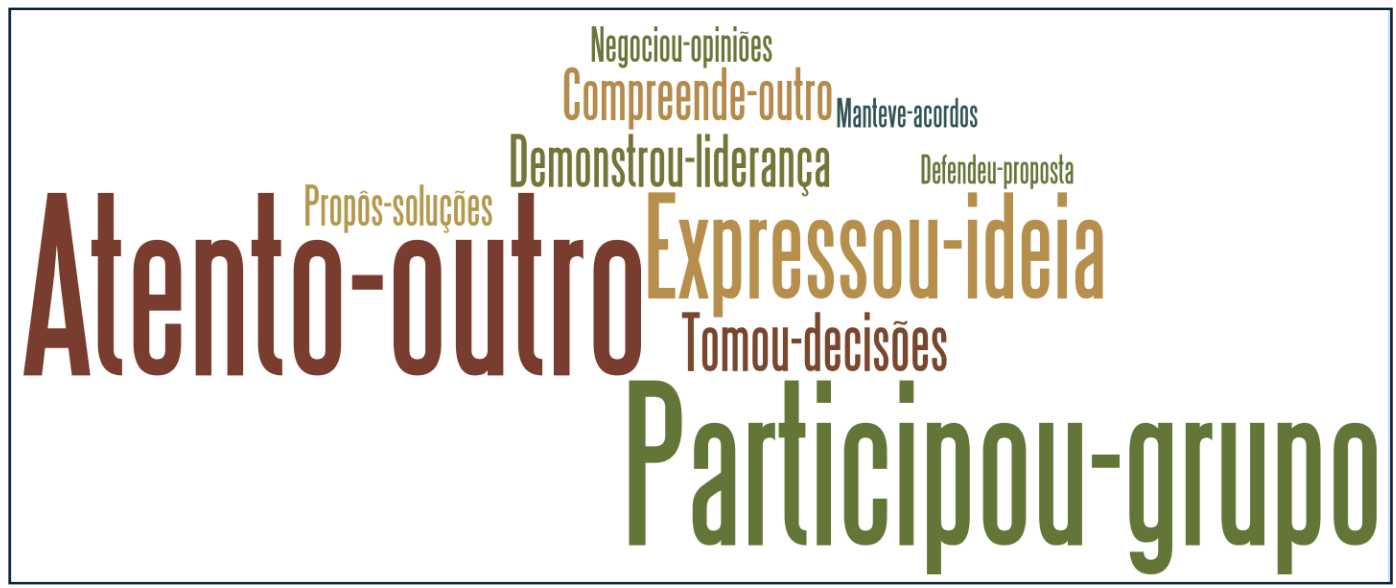

Figura 23 - Nuvem de atitudes com maiores recorrências Fonte: Elaboração própria.

O protocolo do aluno Leo, especificamente, destacou-se dos demais, apresentando recorrências relacionadas a: planejamento e organização de tarefas, transcodificação de linguagens e habilidades envolvidas na produção audiovisual, que não estiveram presentes nos protocolos dos demais alunos observados. Esses resultados podem estar relacionados a fatores externos à oficina, mas também a fatores internos, que propiciaram a este aluno exercer sua postura de liderança. Além disso, ele sempre se mostrou atento e interessado nas aulas, participando das tarefas.

A análise dos protocolos de registro de atitudes dos participantes, associada aos resultados alcançados por Leo, indica que é possível promover o 
desenvolvimento de atitudes relacionadas a habilidades sociocognitivas nas oficinas de cinema na escola. Para tanto, acredito ser necessário que se planejem atividades autênticas, promovidas em contextos interessantes e com objetivos e metodologias que estejam claras não apenas para o professor, mas para todos os envolvidos. Saber que o que será produzido será divulgado na escola ou em festivais pode ser estimulante para os estudantes e motivá-los a cumprir suas tarefas e finalizar o filme (Kearney \& Schuck, 2005). Outro ingrediente importante para manter o interesse dos envolvidos na produção é sustentar o caráter de entretenimento da atividade, pois isso é o que a diferencia das demais propostas escolares, promovendo um ambiente prazeroso e divertido ao aprender. Os jovens produzem filmes porque gostam e não por obrigação e isso pode ser extremamente importante na relação com os colegas, com o professor, com a escola e com a própria aprendizagem (Pereira et al., 2018).

Nesses processos de ensino-aprendizagem, o cinema/audiovisual torna-se "coisa da escola", sujeito a suas propostas, interesses e modos de agir. Escapa, portanto, de suas formas originais de ver e de ser visto, o que traz ganhos e perdas. Entre as perdas, destaco uma excessiva didatização e controle do processo criativo por parte de quem conduz a oficina e uma reprodução de práticas que estimulam pouco a autonomia e a resolução de problemas. Entre os ganhos identificados neste estudo, ressalto a promoção do desenvolvimento de habilidades de agir junto, de atuar em equipe, de colaborar, de dar opiniões consistentes e reformular argumentos para ser melhor compreendido e de ouvir e aceitar a opinião do outro. Isso não é pouco, sobretudo em um contexto político que tende a silenciar divergências em nome da defesa de um único ponto de vista. Porém, os dados produzidos indicam o quanto essas habilidades podem ser melhor desenvolvidas, caso sejam planejadas atividades com esses objetivos. 


\section{9 \\ Referências bibliográficas}

AIDELMAN, N.; COLLEL, L. De las potencias pedagogicas de la creación cinematográfica. In: FRESQUET, Adriana (Org.). Dossiê cinema e educação \#1: uma relação sobre a hipótese de alteridade de Alain Bergala. Rio de Janeiro: UFRJ, 2011.

ALEGRIA, João. O livro de imagens luminosas: Jonathas Serrano e a gênese da cinematografia educativa no Brasil (1889-1937). 2008. Tese (Doutorado em Educação) - Pontifícia Universidade Católica do Rio de Janeiro, Rio de Janeiro, 2008.

AMOR PÉREZ, M.; DELGADO, A. De la competencia digital y audiovisual a la competencia mediática: dimensiones e indicadores. Comunicar: Revista Científica de Educomunicación, v. 20, n. 39, p. 25-34, 2012.

ANDRÉ, Marli. O que é um estudo de caso qualitativo na educação? Revista da FAEEBA: Educação e Contemporaneidade, Salvador, v. 22, n .40, p. 95-103, jul./dez. 2013.

ARAÚJO, S. M. A produção de audiovisuais na escola: caminhos de apropriação da experiência mídia-educativa por crianças e jovens. 2008. Dissertação (Mestrado em Educação) - Pontifícia Universidade Católica do Rio de Janeiro, Rio de Janeiro, 2008.

AREA, M. M. La alfabetización en la sociedad digital. In: AREA, Manuel Moreira; GUTIÉRREZ MARTÍN, A.; VIDAL FERNÁNDEZ, F. (Org.). Alfabetización digital y competencias informacionales. Madrid: Fundación Telefónica y Editorial Ariel, 2012.

BARDIN, Laurence. Análise de conteúdo. São Paulo: Edições 70, 1989.

BARRA, Regina Ferreira. Cinema e educação: narrativas de experiências docentes em colégios de aplicação. 2015. 226f. Tese (Doutorado em Educação) - Universidade Federal do Rio de Janeiro, Rio de Janeiro, 2015.

BAUMAN, Zygmunt. Entrevista sobre a educação: desafios pedagógicos e modernidade líquida. Realizada por Alba Porcheddu. Cadernos de Pesquisa, v. 39, n. 137, p. 661-684, maio/ago. 2009.

BELLONI, Må. Luiza. Tecnologia e formação de professores: rumo a uma pedagogia pós-moderna? Educação e Sociedade, v. 19, n. 65, p. 143-162, 1998.

BENTES, Ivana. Imaginários periféricos e vidas-linguagens: formação audiovisual livre. In: BARBOSA, M. C. S.; SANTOS, M. A. dos. (Org.). Escritos de alfabetização audiovisual. Porto Alegre: Libretos, 2014. 
BERGALA, Alain. A hipótese-cinema: pequeno tratado de transmissão do cinema dentro e fora da escola. Tradução Mônica Costa Netto, Silvia Pimenta. Rio de Janeiro: Booklink/CINEAD-LISE-FE/UFRJ, 2008. (Coleção Cinema e Educação).

BERTI, A. O. Experiências com o cinema na escola: gestos pedagógicos em destaque. 2016. Tese (Doutorado em Educação) - Universidade Federal do Rio de Janeiro, Rio de Janeiro, 2016.

BRASIL, G. A. Juntando pedaços: a importância da alfabetização audiovisual. In: BARBOSA, M. C. S.; SANTOS, M. A. dos. (Org.). Escritos de alfabetização audiovisual. Porto Alegre: Libretos, 2014.

BRASILIANA. Instituto Nacional de Cinema Educativo. Verbete [on-line]. Rio de Janeiro: Museu da Vida/Fiocruz, 2001. Disponível em: http://www.fiocruz.br/brasiliana/cgi/cgilua.exe/sys/start.htm?infoid=418\&sid=3.

Acesso em: 11 ago. 2016.

BRITISH FILM INSTITUTE. Integrating film into education: advocacy report. s/d. Disponível em: https://www.bfi.org.uk/sites/bfi.org.uk/files/downloads/film-21stcentury-literacy-advocacy-report.pdf. Acesso em: 20 out. 2017.

BRITISH FILM INSTITUTE. Using film in schools: a pratical guide. Film: 21st century literacy - a strategy for film education across the UK. [S.I.], 2010. Disponível em: http://www.filmeducation.org/resources/secondary/teaching_with_film/film_in_the _classroom/. Acesso em: 12 ago. 2017.

BULLARA, Bete; MONTEIRO, Marialva. Cinema: uma janela mágica. 3. ed. atual. e ampl. Belo Horizonte: FAE/UFMG, 2015.

BULLARA, Bete. Entrevista ao programa \#Educa. Multirio, 26 jun. 2018. Disponível em: https://www.youtube.com/watch?v=JaMKV9aF9PU. Acesso em: 29 jun. 2018.

BUZATO, Marcelo El Khorui. Cultura digital e apropriação ascendente: apontamento para uma educação 2.0. Educação em Revista, v. 26, n. 3, p. 283304, dez. 2010.

CATELLI, Rosana Elisa. Dos "naturais" ao documentário: o cinema educativo e a educação do cinema entre os anos de 1920 e 1930. 2007. Tese (Doutorado em Multimeios) - Instituto de Artes, Universidade Estadual de Campinas, Campinas, 2007.

CATELLI, Rosana Elisa. Coleção de imagens: o cinema documentário na perspectiva da Escola Nova, entre os anos de 1920 e 1930. Educação e Sociedade, Campinas, v. 31, n. 111, p. 605-624, abr.-jun. 2010.

CELESTINO, R. G. Crianças e suas narrativas audiovisuais. 2015. Dissertação (Mestrado em Educação) - Universidade Federal do Estado do Rio de Janeiro, Rio de Janeiro, 2015. 
COLE, Michael; ENGESTRÖM, Yrjö. Enfoque histórico-cultural de la cognición. In: SALOMON, Gavriel (Comp.). Cogniciones distribuidas: consideraciones psicológicas y educativas. Buenos Aires : Amorrortu, 2001.

COHN, Greice. Pedagogias da videoarte: a experiência do encontro de estudantes do Colégio Pedro II com obras contemporâneas. 2016. Tese (Doutorado em Educação) - Universidade Federal do Rio de Janeiro, Rio de Janeiro, 2016.

CORDEIRO, Kelly Maia. Cinema e juventude: relações criadas pelos jovens dentro e fora da escola. 2013. Dissertação (Mestrado em Educação) Universidade Federal do Estado do Rio de Janeiro, Rio de Janeiro, 2013.

COSTA OLIVEIRA, A. D. Audiovideografia e cultura audiovisual: um estudo de caso com alunos do 9ำ ano do ensino básico, em Educação Visual, no âmbito do projecto curricular de turma. 2011. Dissertação (Mestrado em Ciências da Educação) - Universidade do Minho, Braga, Portugal, 2011. Disponível em: http://hdl.handle.net/1822/19666. Acesso em: 16 out. 2018.

COSTA, S. R. P. Pedagogia da imagem: a autoria na relação educador/educando durante o processo de produção de vídeos na escola. 2014. Dissertação (Mestrado em Educação) - Universidade Federal do Estado do Rio de Janeiro, Rio de Janeiro, 2014.

DA MATTA, Roberto. "O Ofício de Etnólogo, ou como ter Anthropological Blues". In: NUNES, Edson de Oliveira (Org.). A aventura sociológica: objetividade, paixão, improviso e método na pesquisa social. Rio de Janeiro: Zahar Editores, 1978. p. 23-35.

DALL'AGNOL, C. Produção audiovisual como recurso didático-pedagógico no ensino de história: "Como me veem?", "Como eu vejo?" - estudo de caso de adolescentes de uma comunidade em situação de vulnerabilidade social. 2015. Dissertação (Mestrado em História) - Universidade de Caxias do Sul, Caxias do Sul, 2015.

D'ANDREA, Daniella. Contato: um abecedário audiovisual por estudantes de uma escola de cinema. 2018. Dissertação (Mestrado em Educação) Universidade Federal do Rio de Janeiro, Rio de Janeiro, 2018.

DINIZ, Felipe. Notas sobre uma oficina de cinema. In: BARBOSA, M. C. S.; SANTOS, M. A. dos. (Org.). Escritos de alfabetização audiovisual. Porto Alegre: Libretos, 2014.

DOMINGUES, G. R. Abecedário sobre escutas no cinema: percursos de criação cinematográfica com estudantes de educação básica na perspectiva da diferença. 2016. Tese (Doutorado em Educação) - Universidade Federal do Rio de Janeiro, Rio de Janeiro, 2016.

DUARTE, Rosália M. Pesquisa qualitativa em educação: reflexões sobre o trabalho de campo. Cadernos de Pesquisa, São Paulo: Fundação Carlos Chagas, v. 115, n. 115, p. 139-154, 2002.

DUARTE, Rosália M. Entrevistas em pesquisas qualitativas. Educar, Curitiba, n. 24, p. 213-225, 2004. 
DUARTE, Rosália M.; ALEGRIA, João. Formação estética audiovisual: um outro olhar para o cinema a partir da educação. Educação e Realidade: Dossiê Cinema e Educação, Porto Alegre, v. 33, n. 1, p. 59-80, jan./jun. 2008.

DUARTE, Rosália M. Cinema e educação. 3. ed. Belo Horizonte: Autêntica, 2009.

DUARTE, Rosália M.; TAVARES, Marcus T. A dimensão político/educativa das opções estéticas nos manifestos fundadores do cinema como arte. Revista Contemporânea de Educação, v. 5, p. 24-38, 2010.

DUARTE, Rosália et al. Projetos de mídia-educação nas escolas da Rede Pública Municipal do Rio de Janeiro e aprendizagem escolar. Parceria entre a Gerência de Educação e Mídia da SME-RJ e o Instituto Desiderata. Rio de Janeiro, 2016. Disponível em: http://www.grupem.pro.br/2016/12/22/projetos-demidia-educacao-nas-escolas-da-rede-publica-municipal-do-rio-de-janeiro-eaprendizagem-escolar/. Acesso em: 12 out. 2017.

ESHET-ALKALAI, Y. Digital literacy: a conceptual framework for survival skills in the digital era. Jl. of Educational Multimedia and Hypermedia, v. 13, n. 1, p. 93106, 2004.

FANTIN, Monica. Fragmentos e imagens de crianças no cinema: a inversão do olhar. In: REUNIÃO ANUAL DA ANPED, 27., 2004, Caxambu-MG. Anais eletrônicos..., Caxambu: Anped, 2004. Disponível em: <http://27reuniao.anped.org.br/>. Acesso em: 12 fev. 2015.

FANTIN, Monica. Da mídia-educação aos olhares das crianças: pistas para pensar o cinema em contextos formativos. In: REUNIÃO ANUAL DA ANPED, 29., 2006, Caxambu-MG. Anais eletrônicos..., Caxambu: Anped, 2006. Disponível em: <http://29reuniao.anped.org.br/trabalhos/trabalho/GT16-1760-Int.pdf>. Acesso em: 12 ago. 2016.

FANTIN, Monica. Audiovisual na escola: abordagens e possibilidades. In: BARBOSA, M. C. S.; SANTOS, M. A. dos. (Org.). Escritos de alfabetização audiovisual. Porto Alegre: Libretos, 2014.

FARIA, N. V. F. A linguagem cinematográfica na escola: o processo de produção de filmes na sala de aula como prática pedagógica. 2011. Dissertação (Mestrado) - Universidade Estadual Paulista Júlio de Mesquita Filho, São Paulo, 2011.

FERRÉS, Joan. La competencia en comunicación audiovisual: dimensiones e indicadores. Comunicar: Revista Científica de Comunicación y Educación, v. 15, n. 29, p. 100-107, 2007.

FONSECA, Mirna Juliana S. A dimensão formativa de cineclubes universitários. 2014. Dissertação (Mestrado em Educação) - Universidade Federal do Estado do Rio de Janeiro, Rio de Janeiro, 2014. 
FONSECA, Mirna Juliana S. Cinema na escola pra quê? Educação e Cultura Contemporânea, v. 13, n. 31, p. 33-55, 2016. Disponível em: http://revistaadmmade.estacio.br/index.php/reeduc/article/viewArticle/1526.

Acesso em: 24 jun. 2017.

FRANCO, Marília. Hipótese-cinema: múltiplos diálogos. In: FRESQUET, Adriana (Org.). Dossiê cinema e educação \#1: uma relação sobre a hipótese de alteridade de Alain Bergala. Rio de Janeiro: UFRJ, 2011.

FRANCO, Marília. A educação e o cinema que corre nas veias. In: BARBOSA, M. C. S.; SANTOS, M. A. dos. (Org.). Escritos de alfabetização audiovisual. Porto Alegre: Libretos, 2014.

FREIRE, Paulo. Pedagogia da autonomia: saberes necessários à prática educativa. São Paulo: Paz e Terra, 1996. (Coleção Leitura).

FREITAS, M. T. A. Vygotsky e Bakhtin: psicologia e educação - um intertexto. São Paulo: Ática, 1994.

FREITAS, M. T. A. Tecnologias digitais: cognição e aprendizagem. In: REUNIÃO NACIONAL DA ANPED. 37, 2015. Anais eletrônicos... Florianópolis: Anped, 2015. Disponível em: <http://37reuniao.anped.org.br/wpcontent/uploads/2015/02/Trabalho-de-Maria-Teresa-de-

Assun\%C3\%A7\%C3\%A3o-Freitas-para-o-GT16.pdf>. Acesso em: 30 abr. 2015.

FRESQUET, Adriana M. Fazer cinema na escola: pesquisa sobre as experiências de Alain Bergala e Núria Aidelman Feldman. In: REUNIÃO NACIONAL DA ANPED. 31, 2008. Anais eletrônicos... Caxambu-MG: Anped, 2008. Disponível em: <http://31 reuniao.anped.org.br/1trabalho/GT16-4996-Int.pdf>. Acesso em: 12 ago. 2016.

FRESQUET, Adriana M. (Org.). Dossiê cinema e educação \#1 e \#2: uma relação sob a hipótese de alteridade de Alain Bergala. Rio de Janeiro: UFRJ, 2011.

FRESQUET, Adriana M.; NANCHERY, C. Abecedário de cinema com Alain Bergala. Rio de Janeiro: Lecav, 2012. Vídeo digital. color. Disponível em: http://www.cinead.org/videos. Acesso em: 10 jan. 2017.

FRESQUET, Adriana M. Cinema e educação: reflexões e experiências com professores e estudantes de educação básica, dentro e "fora" da escola. Belo Horizonte: Autêntica, 2013. (Coleção Alteridade e Criação, 2).

FRESQUET, Adriana M. Cinema e educação: a lei 13.006. Belo Horizonte: Universo Produção, 2015.

FRESQUET, Adriana (Org.). As origens do cinema: jogos ópticos. Rio de Janeiro: Lecav/Cinead, UFRJ, s/d. Disponível em: http://www.cinead.org/files/jogos_opticos.pdf. Acesso em: 2 jul. 2017.

FRESQUET, Adriana (Org.). Currículo de cinema para escolas de educação básica. Rio de Janeiro: Cinead, s/d. 
FUNDAÇÃO GETÚlIO VARGAS. 29a Pesquisa anual de uso de TI: 2018. Rio de Janeiro, 2018.

GALERA, Nieves; MATSUMOTO, Mitsuko; POVEDA, David. The place of digital devices in the home and family routines of young children (3-7) in Madrid. Media Education: Studi, Ricerche, Buone Pratiche, v. 7, n. 2, p. 303-319, 2016.

GARBIN, Monica Cristina. Uma análise da produção audiovisual colaborativa: uma experiência inovadora em uma escola de ensino fundamental. ETD: Educação Temática Digital, n. extra 12, p. 227-251, 2011.

GARCIA, Janaina Pires. Reflexões sobre currículo e linguagem a partir de uma experiência da Escola de Cinema no CAp/UFRJ. 2010. Dissertação (Mestrado em Educação) - Universidade Federal do Rio de Janeiro, Rio de Janeiro, 2010.

GARCÍA-CANCLINI, N. Diferentes, desiguais e desconectados. 3. ed. Rio de Janeiro: Ed. UFRJ, 2009.

GEERTZ, Cliford. A interpretação das culturas. 13. reimp. Rio de Janeiro: LTC, 2008.

GONÇALVES, Beatriz Moreira Porto. Cinema, educação e o cineclube nas escolas: uma experiência na rede pública do sistema municipal de ensino do Rio de Janeiro. 2013. Dissertação (Mestrado em Educação) - Pontifícia Universidade Católica do Rio de Janeiro, Rio de Janeiro, 2013.

HOBBS, Renee; MOORE, David Cooper. Cinekyd: Exploring the Origins of Youth Media Production. Journal of Media Literacy Education, v. 6, n. 2, p. 23-34, 2014.

Disponível em: <https://digitalcommons.uri.edu/jmle/vol6/iss2/3>. Acesso em: 12 jul. 2018.

HONORATO, Aurélia et al. A vídeo-gravação como registro, a devolutiva como procedimento: pensando sobre estratégias metodológicas na pesquisa com crianças. In: REUNIÃO ANUAL DA ANPED, 29., 2006, Caxambu-MG. Anais eletrônicos..., Caxambu: Anped, 2006. Disponível em: $<$ http://29reuniao.anped.org.br/trabalhos/trabalho/GT16-2172--Int.pdf>. Acesso em: 12 ago. 2016.

HUSBYE, Nicholas E. Of movies and multimodality: film design and modal complexity as literacy pratices in the elementary classroom. 2013. Tese (Doutorado em Filosofia) - Universidade de Indiana, Indiana-EUA, 2013.

ISHAGHPOUR, Youssef. O real, cara e coroa. In: KIAROSTAMI, Abbas. Abbas Kiarostami. Tradução Alvaro Machado, Eduardo Brandão, Samuel Titan Jr. São Paulo: Cosac Naify, 2008. (Coleção Mostra Internacional de Cinema).

JACQUINOT-DELAUNAY, Geneviève. A escola e o fenômeno midiático. Entrevista realizada por Rosa Mà. Cardoso Dalla Costa. Comunicação e Educação, ano 12, n. 3, set./dez. 2007. 
JUNQUEIRA FILHO, G. A.; BARBOSA, M. C. S. Cinema, infância e sala de aula: relato sobre uma disciplina e sua perspectiva de formação de professores na universidade. In: BARBOSA, M. C. S.; SANTOS, M. A. dos. (Org.). Escritos de alfabetização audiovisual. Porto Alegre: Libretos, 2014.

KEARNEY, M.; SCHUCK, S. Students in the director's seat: teaching and learning with student-generated video. In: KOMMERS P.; RICHARDS, G. (Eds.). Proceedings of ED-MEDIA 2005: World Conference on Educational Multimedia, Hypermedia \& Telecommunications. Montreal, Canada: Association for the Advancement of Computing in Education (AACE), 2005. Disponível em: <https://www.learntechlib.org/primary/p/20518/>. Acesso em: 10 jul. 2018.

L'EDEN CINEMA. Où est la maison de mon ami? Conception: Alain Bergala. Paris, 2001-2002. 2 DVDs.

LABRUNIE, Maria das Graças Lino. A produção de vídeos na escola: um estudo exploratório. 2017. Tese (Doutorado em Educação) - Universidade Estácio de Sá, Rio de Janeiro, 2017.

LEANDRO, Anita. Da imagem pedagógica à pedagogia da imagem. Comunicação e Educação, ano 7, n. 21, maio/ago. 2001.

LEANDRO, Anita. Posfácio: uma questão de ponto de vista. In: FRESQUET, Adriana (Org.). Dossiê cinema e educação \#2: uma relação sob a hipótese de alteridade de Alain Bergala. Rio de Janeiro: UFRJ, 2011.

LEITE, C.; ALEGRIA, J. Imaginário, linguagem audiovisual e identidade em vídeos realizados por jovens, 2005. Arquivo dos autores disponível em: https://goo.gl/fyDVQi. Acesso em: 10 nov. 2017.

LEITE, Camila. Nós na Fita: reflexões sobre uma TV de Rua feita por jovens. In: REUNIÃO ANUAL DA ANPED, 29., 2006, Caxambu-MG. Anais eletrônicos..., Caxambu: Anped, 2006. Disponível em: <http://29reuniao.anped.org.br/trabalhos/trabalho/GT16-2554--Int.pdf>. Acesso em: 12 ago. 2016.

LEITE, Gisela Pascale et al. Cinema, infância e escola: novos olhares pata a educação básica. In: FRESQUET, Adriana (Org.). Dossiê cinema e educação \#2: uma relação sob a hipótese de alteridade de Alain Bergala. Rio de Janeiro: UFRJ, 2011.

LEITE, Gisela Pascale de C. Linguagem cinematográfica no currículo da educação básica: uma experiência de introdução ao cinema na escola. 2012. Dissertação (Mestrado em Educação) - Universidade Federal do Rio de Janeiro, Rio de Janeiro, 2012.

LEITE, J. E. R. Natureza social da cognição. Veredas: Rev. Est . Ling., Juiz de Fora, v. 7, n. 1-2, p. 217-232, jan./dez. 2003.

LIMA, D. S. L. Atenção gravando!: produção de vídeos por alunos do ensino médio - a língua como objeto de reflexão. 2013. Dissertação (Mestrado em Letras) - Universidade Católica de Pelotas, Pelotas, 2013. 
LIMA, E. K. V. Literacinese ou da escrita [literária] com imagens... Em movimento. 2015. Dissertação (Mestrado) - Universidade Federal de Santa Maria, Santa Maria, 2015.

LIVINGSTONE, Sonia. Internet literacy: a negociação dos jovens com as novas oportunidades on-line. Matrizes, ano 4, n. 2, p. 11-42, jan./jun. 2011.

LUNA, C. J. C. Luz, câmera, ação: os vídeos na educação em ciências e produção de saberes. 2014. Dissertação (Mestrado Profissional em Ensino de Ciências e Matemática) - Universidade Federal de Pelotas, Pelotas, 2014.

MACHADO, Carla Silva. "Espelho, espelho meu?": narrativas audiovisuais acerca das sobre juventudes e representações juvenis. 2017. Tese (Doutorado em Educação) - Pontifícia Universidade Católica do Rio de Janeiro, Rio de Janeiro, 2017.

MAHEIRIE, K. et al. Subjetivação, criação e produção audiovisual: uma experiência em torno de um espetáculo musical. Psicologia \& Sociedade, 26 (n. spe. 2), p. 84-92, 2014.

MARINOVIC, J. A. Produção de vídeos caseiros pelos próprios alunos como estratégia para melhorar a aprendizagem dos conceitos abordados nas aulas regulares de física do ensino médio e com ênfase nos registros das atividades propostas. 2012. Dissertação (Mestrado em Ciências Exatas) - Universidade Federal de São Carlos, São Carlos, 2012.

MARTÍN-BARBERO, Jesús. Desafios culturais da comunicação à educação. Comunicação e Educação, São Paulo, n. 18, p. 51-61, maio/ago. 2000.

MARTÍN-BARBERO, Jesús. A comunicação na educação. São Paulo: Contexto, 2014.

MATELA, Rose Clair. Cineclubismo: memórias dos anos de chumbo. Rio de Janeiro: Luminária Academia, 2008.

MAURICIO, D. M. T. Invenção do possível: o uso e a produção de filmes nas aulas de história. 2010. Dissertação (Doutorado em Educação) - Universidade de São Paulo, São Paulo, 2010.

MCLOUGHLIN, C. What ICT-related skills and capabilities should be considered central to the definition of digital literacy? In: BASTIAENS, T.; EBNER, M. (Eds.). Proceedings of edmedia: World Conference on Educational Media and Technology. [S.:I.]: Association for the Advancement of Computing in Education (AACE), 2011. p. 471-475.

MELLOUKI, M'Hammed; GAUTHIER, Clermont. O professor e seu mandato de mediador: herdeiro, intérprete e crítico. Educação e Sociedade, v. 25, n. 87, p. 537-571, maio/ago. 2004.

MENEZES, Jaileila; ADRIÃO, Karla G.; RIOS, Luis F. Jovens, câmera, ação: reflexões sobre os usos dos dispositivos móveis de mídia em um projeto de mobilização social. Recife: Editora UFPE, 2017. 
MERLO, Andréia Todeschini. A experiência da construção da imagem na escola pública: impactos no currículo e desafios no cotidiano. In: BARBOSA, M. C. S.; SANTOS, Maria Angélica (Org.). Escritos de alfabetização audiovisual. Porto Alegre: Libretos, 2014.

MIGLIORIN, Cezar. Cinema e escola, sob o risco da democracia. In: FRESQUET, Adriana (Org.). Dossiê cinema e educação \#1: uma relação sobre a hipótese de alteridade de Alain Bergala. Rio de Janeiro: UFRJ, 2011.

MIGLIORIN, Cezar. O cinema, a escola, o estudante e a invenção de mundos. In: BARBOSA, M. C. S.; SANTOS, M. A. dos. (Org.). Escritos de alfabetização audiovisual. Porto Alegre: Libretos, 2014.

MIGLIORIN, Cezar. Inevitavelmente cinema: educação, política e mafuá. Rio de Janeiro: Beco do Azougue, 2015.

MIGLIORIN, Cezar et al. Cadernos do Inventar: cinema, educação e direitos humanos. Niterói: UFF/Secadi, 2016.

MIGLIORIN, Cezar; BARROSO, Eliana. Pedagogias do cinema: montagem. Significação: Revista De Cultura Audiovisual, v. 43, n. 46, p. 15-28, 2016.

MILLIET, Joana Sobral. Pedagogias da animação: professores criando filmes com seus alunos na escola. 2014. Dissertação (Mestrado em Educação) Universidade Federal do Estado do Rio de Janeiro, Rio de Janeiro, 2014.

MIRANDA, F. M. W. Produção de vídeo na escola: um estudo sobre processos de aprendizagem audiovisual. 2015. Tese (Doutorado em Artes) - Universidade de Campinas, Campinas, 2015.

MONDADA, Lorenza. Cognition et parole-en-interaction. Veredas: Revista de Estudos Linguísticos, v. 6, n. 1, p. 9-27, jan./jun. 2002.

MORENO, Cecilia Beatriz; ISON, Mirna Susana. Habilidade socio-cognitivas para resolver problemas junto a sus pares. Revista CES Psicologia, v.6, n. 1. jul./dec. 2013.

NAKACHE, Débora. Producir cine em escuelas de Buenos Aires: visitando esta experiencia com ojos de alteridade. In: FRESQUET, Adriana (Org.). Dossiê cinema e educação \#1: uma relação sob a hipótese de alteridade de Alain Bergala. Rio de Janeiro: UFRJ, 2011. p. 69-85.

NASCIMENTO, A. M. Percurso histórico do Cineduc: o "fazer-se" de seus protagonistas entre 1969 e a década de 1980. Dissertação (Mestrado em Educação) - Universidade Federal do Estado do Rio de Janeiro, Rio de Janeiro, 2013.

NOGUEIRA, M. G. Letramento(s) digital(is) e jovens de periferia: o transitar por (multi)letramento(s) digital(is) durante o processo de produção de vídeos de bolso. 2014. Dissertação (Mestrado em Educação Matemática e tecnologias) Universidade Federal de Pernambuco, Recife, 2014. 
NORTON, Maíra. Cinema oficina: técnica e criatividade no ensino de audiovisual. Niterói: Editora UFF, 2013.

NORTON, T. O cinema e o rural em uma escola no campo. 2014. Dissertação (Mestrado em Educação) - Universidade Federal do Rio de Janeiro, Rio de Janeiro, 2014.

NOSSA TELA. Vídeo nas escolas: dicas para a produção. São Paulo, 2011.

OLIVEIRA, E. Fazendo vídeo na escola: o audiovisual como instrumento de mediação pedagógica. 2011. Dissertação (Mestrado) - Universidade Federal da Paraíba, João Pessoa, 2011.

OLIVEIRA, P. J. Uma metodologia para a produção de audiovisual: o uso das tecnologias emergentes com os jovens. 2015. Dissertação (Mestrado em Artes Visuais) - Universidade Estadual de Campinas, Campinas, 2015.

OLMECZUCH, F. W. O que se aprende quando se aprende cinema no hospital? 2016. Tese (Doutorado em Educação) - Universidade Federal do Rio de Janeiro, Rio de Janeiro, 2016.

OROFINO, Ma. Isabel. Mídias e mediação escolar: pedagogia dos meios, participação e visibilidade. São Paulo: Cortez/Instituto Paulo Freire, 2005. (Guia da escola cidadã, 12).

PACHECO, Raquel. Cinema e educação: estudos de caso no Brasil e em Portugal. 2015. Tese (Doutorado em Ciências da Comunicação) - Universidade Nova Lisboa, Lisboa, 2015.

PACHECO, Raquel. Reflexões sobre o campo do cinema e educação. Revista Teias, v. 17, n. 47, p. 85-100, jan./mar. 2016. Cinema e Educação em Debate.

PAZ, K. R. A. Saracuruna News: produção audiovisual como dispositivo de subjetivação entre jovens da periferia de Duque de Caxias. 2012. Dissertação (Mestrado em Educação, Cultura e Comunicação) - Universidade do Estado do Rio de Janeiro, Rio de Janeiro, 2012.

PEDROSA, L. L. C. Nas mãos dos jovens: modalidades de uso do celular para produção de vídeos no contexto de uma escola pública. 2012. Dissertação (Mestrado) - Universidade de Brasília, Brasília, 2012.

PEREIRA, Marcus Vinicius; BARROS, Susana de Souza. Análise da produção de vídeos por estudantes como uma estratégia alternativa de laboratório de física no Ensino Médio. Rev. Bras. Ensino Fís., São Paulo, v. 32, n. 4, out./dez. 2010. 
PEREIRA, Sara. Educação para os media e cidadania. Braga, Portugal, jan. $2000 . \quad$ Disponível em: <https://repositorium.sdum.uminho.pt/bitstream/1822/4768/1/Cidadania\%20e\%20 Educa\%C3\%A7\%C3\%A30\%20para\%20os\%20Media.pdf>. Acesso em: 30 abr. 2018.

PEREIRA, Sara et al. Media uses and production practices: case study with teens from Portugal, Spain and Italy. Comunicación y Sociedad, n. 33, p. 89-114, sep./dec. 2018.

PERRELLI, Maria Aparecida de Souza et al. Percursos de um grupo de pesquisa-formação: tensões e (re)construções. Revista Brasileira de Estudos Pedagógicos, Brasília, v. 94, n. 236, p. 275-298, jan./abr. 2013.

PIMENTEL, Erizaldo Cavalcanti Borges. Cine com ciência: luz, câmera educação! 2013. Tese (Doutorado em Educação) - Universidade de Brasília, Brasília-DF, 2013.

PINO, Angel. A interação social: perspectiva sócio-histórica. Idéias, São Paulo, n.20, p. 49-58, 1993.

PIRES, C. L. Educação, corpo e imagem: desvelando caminhos para a educação emancipatória por meio da produção audiovisual. 2014. Tese (Doutorado em Educação) - Universidade Federal da Bahia, Salvador, 2014.

PIRES, Eloiza Gurgel. Experiência audiovisual nos espaços educativos: possíveis interseções entre educação e comunicação. Educação e Pesquisa, São Paulo, v. 36, n. 1, p. 281-295, jan./abr. 2010.

PRANDINI, P.D. A cor na voz: linguagem e identidade negra em histórias de vida digitalizadas contadas por meio de práticas educomunicativas. Dissertação (Mestrado). São Paulo: USP, 2013.

RANCIÈRE, Jacques. O mestre ignorante: cinco lições sobre a emancipação intelectual. 3. ed. 3. reimp. Belo Horizonte: Autêntica, 2013.

REIS JÚNIOR, Antônio. Cinema brasileiro na escola pública: reconhecimento na diferença. 2010. Tese (Doutorado em Educação) - Universidade Estadual de Campinas, Campinas, 2010.

ROURE, Glacy Q. de. Cinema, educação e psicanálise: uma questão de transmissão. In: REUNIÃO ANUAL DA ANPED, 30., 2007, Caxambu-MG. Anais eletrônicos..., Caxambu: Anped, 2006. Disponível em: $<$ http://30reuniao.anped.org.br/trabalhos/GT16-3724--Int.pdf>. Acesso em: 12 ago. 2016.

SÁ, Patrícia Teixeira. A construção do conhecimento histórico na sala de aula em uma escola da rede municipal de ensino do Rio de Janeiro. 2016. Tese (Doutorado em Educação) - Pontifícia Universidade Católica do Rio de Janeiro, Rio de Janeiro, 2016. 
SALDANHA, F. G. G. Oficina educomunicativa de produção de vídeos: construção de significados sobre problemas socioambientais. 2016. Dissertação (Mestrado) - Universidade Federal de Uberlândia, 2016.

SANTOS, M. A.; BARBOSA, M. C. S; LAZZARETI, A. À luz da lei. In: FRESQUET, Adriana. (Org.). Cinema e educação: a lei 13.006 - reflexões, perspectivas e propostas. Belo Horizonte: Universo Produções, 2015. Disponível em: $<\mathrm{http}: / /$ www.redekino.com.br/wpcontent/uploads/2015/07/Livreto_Educacao10CineOP_WEB.pdf>. Acesso em: 15 nov. 2015.

SANTOS, J. C. Fazendo vídeos no Colégio Ottília: tecnologia e arte como ação coletiva. 2008. Dissertação (Pós-Graduação em Tecnologia) - Universidade Tecnológica Federal do Paraná, Curitiba, 2008.

SANTOS, R. C. Um trajeto católico de educação pelo/para o cinema no Brasil: redes, práticas e memórias. 2016. Tese (Doutorado em Memória: Linguagem e Sociedade) - Universidade Estadual do Sudoeste da Bahia, Vitória da Conquista, 2016.

SATO, M. A. V. Tecnologias digitais da informação e comunicação: explorando as possibilidades pedagógicas da produção de vídeos. 2015. Dissertação (Mestrado em Educação) - Universidade Estadual Paulista, Bauru, 2015.

SILVA, A. C. S. Arte, mídia e cinema na escola: um ensinar que (me) ensina! 2012 Dissertação (Mestrado) - Universidade Federal de Santa Catarina, Florianópolis, 2012.

SILVA, D. G. Uma experiência de cinema expandido no espaço escolar. 2017. Dissertação (Mestrado em Educação) - Universidade Federal do Rio de Janeiro, Rio de Janeiro, 2017.

SILVA, J. U. Luz, câmera, assimetria na inter-ação: funções do professor assumidas por alunos. 2015. Dissertação (Mestrado em Educação) Universidade Federal de Juiz de Fora, Juiz de Fora, 2015.

SOBRAL, Jacqueline. Adultos, smartphones e crianças pequenas: um estudo sobre famílias midiatizadas. 2018. Tese (Doutorado em Educação) - Pontifícia Universidade Católica do Rio de Janeiro, Rio de Janeiro, 2018.

SOUSA, Anderson Luiz André. Entrevistar. In: FONSECA, Tania Mara Galli; NASCIMENTO; Maria Lívia; MARASCHIN, Cleci (Org.). Pesquisar na diferença: um abecedário. Porto Alegre: Sulina, 2012. p. 85-86.

SULZBACH, Liliana. O projeto cinema em quadra. In: BARBOSA, M. C. S.; SANTOS, M. A. dos. (Org.). Escritos de alfabetização audiovisual. Porto Alegre: Libretos, 2014.

SUN, Koun-Tem; WANG, Chun-Huang; LIU, Ming-Chi. Stop-motion para la alfabetización digital en Educación Primaria. Comunicar, v. 25, n. 51, p. 93-103. 2017. 
TAVARES, Marcus; DUARTE, Rosália; JORDÃO, Carolina. Prática mídiaeducativa de análise de produtos e conteúdos midiáticos nas escolas da Prefeitura do Rio de Janeiro. Revista Educação e Cultura Contemporânea, v. 13, n. 31, p. 323-349, ago. 2016.

THOLLON-POMMEROL, Claude. Pédagogie audio-visuelle: histoire et actualité. Genève: Université de Genève, Faculté de Psychologie et des Sciences de L'éducation, 1983.

TOLEDO, Moira. Educação popular audiovisual no Brasil: panorama, 1990-2009. Tese (Doutorado em Estudos dos Meios e da Produção Midiática) Universidade de São Paulo, São Paulo, 2010. v. 1.

TOLEDO, Moira. Audiovisual: uma revolução em potencial para a sua sala de aula. In: BARBOSA, M. C. S.; SANTOS, M. A. dos. (Org.). Escritos de alfabetização audiovisual. Porto Alegre: Libretos, 2014.

VALLADARES, Lícia. Os dez mandamentos da observação participante. Revista Brasileira de Ciências Sociais, v. 22, n. 63, p. 153-155, 2007.

VEGA, Alicia. Oficina de cinema para crianças. Chile: Ocho Libros Editores, 2012.

VIANNA, H. M. Pesquisa em educação: a observação. Brasília: Plano Editora, 2003.

VIGOTSKI, L. S. A construção do pensamento e da linguagem. Tradução Paulo Bezerra. 2. ed. São Paulo: Martins Fontes, 2009.

WEBER, Florence. A entrevista, a pesquisa e o íntimo, ou: por que censurar seu diário de campo? Horizontes Antropológicos, Porto Alegre, ano 15, n. 32, p. 157170, jul./dez. 2009.

WIKIPÉDIA. Lanterna mágica. Verbete. Disponível em: https://pt.wikipedia.org/wiki/Lanterna_m\%C3\%A1gica. Acesso em: 11 jan. 2019.

Tese revisada e formatada por Mirna Juliana.

(mirnarevisora@gmail.com) 
Apêndices

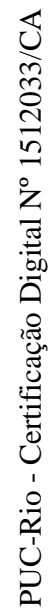




\section{Apêndice A \\ Protocolo de observação}

HABILIDADES DESENVOLVIDAS EM ATIVIDADES DE PRODUÇÃO AUDIOVISUAL

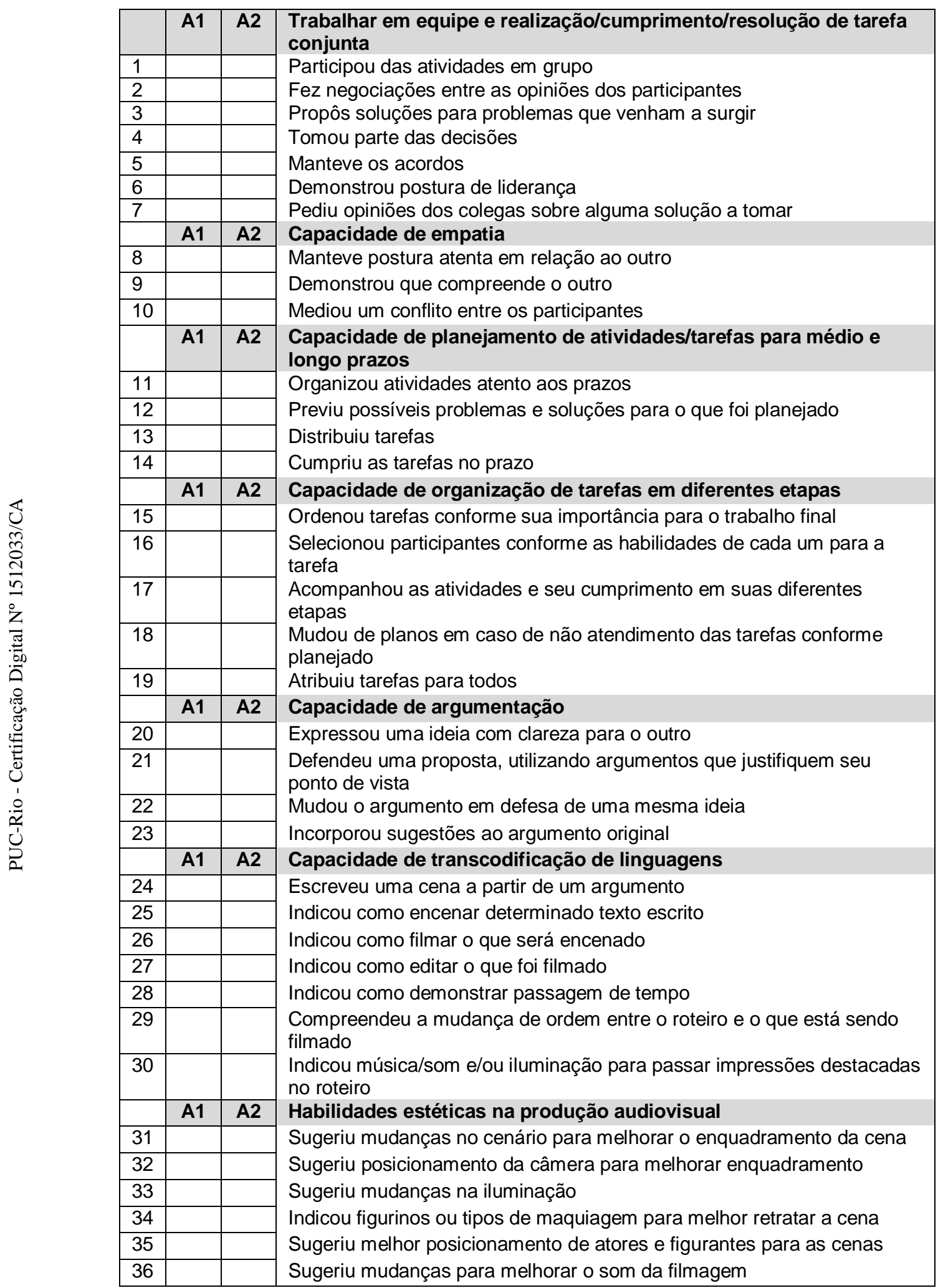

No protocolo devo indicar as atitudes observadas numa escala de 0 a 6 para demarcar a intensidade das ações: 0 - nada; 1 - muito pouco; 2 - pouco; 3 - médio; 4 - um pouco acima da média; 5 - acima da média; 6 - superou as expectativas. 


\section{Apêndice B \\ Roteiros de entrevistas realizadas na pesquisa}

\section{Professor/ Gestor/ Coordenador:}

1) Informações importantes: disciplina que leciona; séries que atende; desde quando atua nessa escola.

2) Você teve algum contato com os alunos que participam da oficina de vídeo?

3) Como você percebe o interesse dos alunos pela oficina de vídeo?

4) Os alunos comentam sobre a produção do filme em suas aulas? Tem algo que chame sua atenção em relação ao interesse deles pela oficina?

5) Você percebeu alguma mudança no comportamento dos alunos que participam da oficina em relação à escola, à $s$ aulas, à realização das tarefas escolares, à frequência e à participação depois que começaram a fazer parte da oficina?

6) Você lembra de algum caso de aluno em especial que tenha modificado seu comportamento após ter participado dessa oficina?

7) Você nota alguma mudança no desempenho ou na aprendizagem do conteúdo de sua disciplina nos alunos que passaram a frequentar a oficina?

\section{Alunos que tenham feito a oficina}

8) Informações importantes: em que série participou da oficina; fez a oficina mais de uma vez; qual filme fez.

9) Por que você escolheu fazer essa oficina?

10) O que vocês faziam durante a oficina?

11) Conta como foi essa experiência pra você?

12) Você lembra de ter aproveitado alguma coisa que aprendeu nas demais disciplinas para usar na oficina de vídeo?

13) Você lembra da oficina ter ajudado em alguma coisa das disciplinas escolares?

14) Quando lembra da oficina de vídeo, o que vem à sua mente, quais as suas lembranças em relação a esse período?

15) Você recomendaria essa oficina de vídeo para os alunos da escola ou alguém em especial? Por quê?

\section{Entrevista final com cartões: alunos que participaram da oficina}

16) Antes da oficina, o que vocês achavam que fariam aqui? (aberta)

17) Como foi a experiência de escreverem juntos o roteiro? (cartões)

18) Para escrever a história, vocês se colocaram no lugar dos personagens pra saber o que eles fariam, falariam ou como estavam se sentindo? (aberta)

19) Como é se colocar no lugar do personagem pra saber como ela está se sentindo? (cartão)

20) Como você contribuiu para a produção do filme? (cartões)

21) Como foi a experiência de trabalhar com esse grupo? (cartões)

22) O que você acha que aprendeu com essa experiência? (cartões)

23) Teve algo nessa oficina que você usou nas outras aulas ou em casa? (aberta)

24) O que você diria para alguém se fosse recomendar essa oficina? (aberta) 


\section{Apêndice C \\ Termos de Consentimento Livre e Esclarecido}

\section{TERMO DE CONSENTIMENTO LIVRE E ESCLARECIDO}

Prezado(a) Professor(a)/ Gestor(a),

PUC de doutorado intitulada "Aprendizagem da linguagem audiovisual e aprendizagem escolar: uma relação em construção" que tem por objetivo: descrever o processo de aprendizagem da linguagem audiovisual na escola e compreender a contribuição deste processo para a relação dos alunos com a escola e com os conteúdos escolares. Esse projeto é uma continuação da pesquisa "Projetos de mídia-educação nas escolas da Rede Pública Municipal de Ensino do Rio de Janeiro", realizada em 2015/2016 pelo Grupo de Pesquisa Educação e Mídia, da PUC-Rio, em parceria com a Gerência de Mídia e Educação da SME e com o Instituto Desiderata, que mapeou, descreveu e analisou a presença e o funcionamento de projetos de mídia e educação em escolas da rede pública municipal de ensino, no intuito de oferecer subsídios à SME para elaboração de políticas e realização de investimentos nessa área.

Você foi selecionado(a) por estar nesse momento em uma das escolas da rede. Sua participação não é obrigatória. A qualquer momento, você poderá desistir de participar e retirar seu consentimento. Sua recusa, desistência ou retirada de consentimento não acarretará prejuízo. A participação não é remunerada nem implicará em gastos para você.

Sua participação nesta pesquisa consistirá em conceder uma entrevista gravada em áudio sobre a "Oficina de Vídeo" que ocorre na sua escola. A intenção da pesquisa é analisar a repercussão da oficina para a aprendizagem dos alunos e não avaliar a oficina em si ou o professor dela.

Os dados obtidos por meio desta pesquisa serão confidenciais e não serão divulgados em nível individual, visando assegurar o sigilo de sua participação e a de sua escola. A pesquisadora responsável se compromete a tornar públicos nos meios acadêmicos e científicos os resultados obtidos de forma consolidada sem qualquer identificação de indivíduos participantes.

Caso você concorde em participar desta pesquisa, assine ao final deste documento, que possui duas vias, sendo uma delas sua, e a outra, da pesquisadora responsável pela pesquisa.

Seguem os contatos e o endereço institucional da pesquisadora responsável, onde você poderá tirar suas dúvidas sobre o projeto e sua participação nele, agora ou a qualquer momento.

Contatos da pesquisadora responsável: Mirna Juliana Santos Fonseca, doutoranda em Educação da PUC-Rio. E-mail: mirnajuliana@gmail.com; Telefone (21) 98183-5070.

Endereço postal: Faculdades Católicas, Departamento de Educação. Marquês de São Vicente, 225, Gávea, CEP 22451-900.

Declaro que entendi os objetivos, riscos e benefícios de minha participação na pesquisa, e que concordo em participar.

Rio de Janeiro, de de 2017.

Assinatura do(a) participante:

Assinatura da pesquisadora: 


\section{TERMO DE CONSENTIMENTO LIVRE E ESCLARECIDO}

\section{Prezado/a estudante,}

Você está sendo convidado(a) a participar, como voluntário(a), da pesquisa

PUC de doutorado intitulada "Aprendizagem da linguagem audiovisual e aprendizagem

escolar: uma relação em construção" que tem por objetivo: descrever o processo de aprendizagem da linguagem audiovisual na escola e compreender a contribuição deste processo para a relação dos alunos com a escola e com os conteúdos escolares. Esse projeto é uma continuação da pesquisa "Projetos de mídia-educação nas escolas da Rede Pública Municipal de Ensino do Rio de Janeiro", realizada em 2015/2016 pelo Grupo de Pesquisa Educação e Mídia, da PUC-Rio, em parceria com a Gerência de Mídia e Educação da SME e com o Instituto Desiderata, que mapeou, descreveu e analisou a presença e o funcionamento de projetos de mídia e educação em escolas da rede pública municipal de ensino, no intuito de oferecer subsídios à SME para elaboração de políticas e realização de investimentos nessa área.

Você foi selecionado/a por ser, neste momento, estudante de uma das escolas da rede. Sua participação não é obrigatória. A qualquer momento, você poderá desistir de participar e retirar seu consentimento. Sua recusa, desistência ou retirada de consentimento não acarretará prejuízo. A participação não é remunerada nem implicará em gastos para os participantes.

Sua participação nesta pesquisa consistirá em permitir que a pesquisadora observe as atividades realizadas no âmbito da oficina de vídeo, desenvolvida em sua escola e conceder uma entrevista gravada em áudio e vídeo sobre essa atividade. Solicitamos sua autorização para acompanhar e registrar, por escrito e, eventualmente, em vídeo e áudio, algumas das atividades desenvolvidas no projeto. Nossas observações não comprometerão o curso normal das atividades e serão agendadas previamente, vindo a ocorrer em dias e horários que o coordenador do projeto e seus demais integrantes julgarem mais convenientes.

Os dados obtidos por meio desta pesquisa serão confidenciais e não serão divulgados em nível individual, visando assegurar o sigilo de sua participação e a de sua escola. O pesquisador responsável se comprometeu a tornar públicos nos meios acadêmicos e científicos os resultados obtidos de forma consolidada sem qualquer identificação de indivíduos participantes.

Caso você concorde em participar desta pesquisa, assine ao final deste documento, que possui duas vias, sendo uma delas sua, e a outra, do pesquisador responsável / coordenador da pesquisa.

Seguem os telefones e o endereço institucional do pesquisador responsável e do Comitê de Ética em Pesquisa - CEP, onde você poderá tirar suas dúvidas sobre o projeto e sua participação nele, agora ou a qualquer momento.

Contatos do pesquisador responsável: Mirna Juliana Santos Fonseca, Estudante do Doutorado em Educação da PUC-Rio. E-mail: mirnajuliana@gmail.com; Telefone (21) 98183-5070.

Endereço postal: Faculdades Católicas, Departamento de Educação. Marquês de São Vicente, 225, Gávea, CEP 22451-900

Declaro que entendi os objetivos, riscos e benefícios de minha participação na pesquisa, e que concordo em participar.

Rio de Janeiro, de de

Nome do(a) estudante:

Assinatura do(a) responsável pelo estudante:

Assinatura do(a) pesquisador(a): 


\section{Apêndice D \\ Dissertações sobre produção audiovisual realizada por crianças e jovens da educação básica}

\begin{tabular}{|c|c|c|c|}
\hline $\begin{array}{l}\frac{1}{0} \\
\frac{0}{3} \\
\frac{1}{\mathbb{E}}\end{array}$ & Título & Objetivos & Resultados/ Conclusões \\
\hline 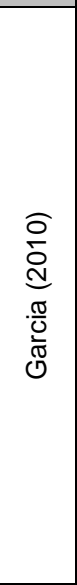 & $\begin{array}{l}\text { Reflexões sobre } \\
\text { currículo e } \\
\text { linguagem a } \\
\text { partir de uma } \\
\text { experiência da } \\
\text { Escola de } \\
\text { Cinema no } \\
\text { CAp/UFRJ }\end{array}$ & $\begin{array}{l}\text { Refletir sobre currículo e } \\
\text { linguagem cinematográfica } \\
\text { em diálogo constante com } \\
\text { as experimentações } \\
\text { desenvolvidas na escola de } \\
\text { cinema. }\end{array}$ & $\begin{array}{l}\text { Considerar a implementação } \\
\text { do cinema - como arte, } \\
\text { linguagem artística, cultura e } \\
\text { conhecimento - no currículo } \\
\text { das escolas constitui uma } \\
\text { possibilidade em apostar numa } \\
\text { educação de qualidade, que } \\
\text { introduz de forma consistente o } \\
\text { ato criativo e penetra mesmo } \\
\text { que timidamente o } \\
\text { conhecimento da arte e de sua } \\
\text { história, pois o cinema tem } \\
\text { ajudado a olhar com mais } \\
\text { atenção o nosso entorno e a } \\
\text { nós mesmos num mundo } \\
\text { disperso e acelerado. }\end{array}$ \\
\hline 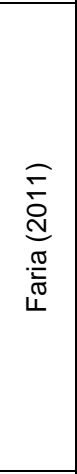 & $\begin{array}{l}\text { A linguagem } \\
\text { cinematográfica } \\
\text { na escola: o } \\
\text { processo de } \\
\text { produção de } \\
\text { filmes na sala } \\
\text { de aula como } \\
\text { prática } \\
\text { pedagógica }\end{array}$ & $\begin{array}{l}\text { Rediscutir a possibilidade de } \\
\text { utilizar o cinema em sala de } \\
\text { aula na perspectiva da } \\
\text { reflexão e da elaboração do } \\
\text { conhecimento a partir do } \\
\text { emprego da linguagem } \\
\text { cinematográfica nas várias } \\
\text { fases da produção de filmes } \\
\text { em curta-metragem. }\end{array}$ & $\begin{array}{l}\text { A aplicabilidade do cinema } \\
\text { como recurso pedagógico a } \\
\text { partir da produção de filmes } \\
\text { pelos alunos pode contribuir } \\
\text { para a alfabetização } \\
\text { audiovisual e para a formação } \\
\text { do sujeito crítico que percebe e } \\
\text { compreende o contexto e se } \\
\text { expressa por meios dos } \\
\text { códigos audiovisuais } \\
\text { proporcionando, assim, uma } \\
\text { aprendizagem significativa em } \\
\text { arte. }\end{array}$ \\
\hline 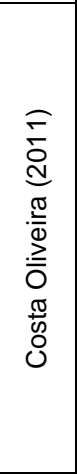 & $\begin{array}{l}\text { Audiovideografi } \\
\text { a e cultura } \\
\text { audiovisual: um } \\
\text { estudo de caso } \\
\text { com alunos do } \\
\text { 9o ano do } \\
\text { ensino básico } \\
\text { em Educação } \\
\text { Visual, no } \\
\text { âmbito do } \\
\text { projecto } \\
\text { curricular de } \\
\text { turma }\end{array}$ & $\begin{array}{l}\text { Tentando incrementar a } \\
\text { cultura audiovisual na } \\
\text { escola, objetivou-se que os } \\
\text { alunos: adquirissem } \\
\text { competências de uso das } \\
\text { tecnologias vídeo; } \\
\text { desenvolvessem um olhar } \\
\text { crítico e reflexivo sobre } \\
\text { factos e acontecimentos, } \\
\text { além da criatividade e da } \\
\text { capacidade comunicativa. }\end{array}$ & $\begin{array}{l}\text { Os jovens realizadores de } \\
\text { narrativas audiovisuais } \\
\text { desenvolveram competências } \\
\text { no âmbito das tecnologias, no } \\
\text { âmbito da forma como lidam } \\
\text { com os elementos das } \\
\text { linguagens, no diálogo que } \\
\text { estabelecem com o imaginário, } \\
\text { no modo de falarem de si e } \\
\text { das suas questões, em suma, } \\
\text { no modo de interagirem com o } \\
\text { mundo. }\end{array}$ \\
\hline 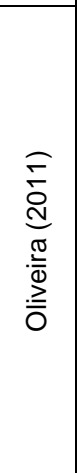 & $\begin{array}{l}\text { Fazendo vídeo } \\
\text { na escola, o } \\
\text { audiovisual } \\
\text { como } \\
\text { instrumento de } \\
\text { mediação } \\
\text { pedagógica }\end{array}$ & $\begin{array}{l}\text { Discutir as possibilidades do } \\
\text { uso das mídias em sala de } \\
\text { aula analisando as situações } \\
\text { nas quais os alunos } \\
\text { participam criando vídeos; } \\
\text { analisar a utilização do vídeo } \\
\text { na escola com os alunos } \\
\text { participando como } \\
\text { produtores; investigar como } \\
\text { as TIC podem ser } \\
\text { mediadoras para uma } \\
\text { educação com perspectiva } \\
\text { dialógica e transformadora. }\end{array}$ & $\begin{array}{l}\text { A produção de vídeos pelos } \\
\text { alunos pode ser entendida } \\
\text { como uma importante } \\
\text { ferramenta de transformação } \\
\text { do processo educativo. }\end{array}$ \\
\hline
\end{tabular}




\begin{tabular}{|c|c|c|c|}
\hline 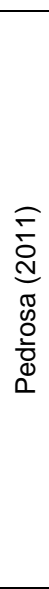 & $\begin{array}{l}\text { Nas mãos dos } \\
\text { jovens: } \\
\text { modalidades de } \\
\text { uso do celular } \\
\text { para produção } \\
\text { de vídeos no } \\
\text { contexto de uma } \\
\text { escola pública }\end{array}$ & $\begin{array}{l}\text { Analisar como a experiência } \\
\text { de produção de vídeos com } \\
\text { celular se manifesta nas } \\
\text { relações diretas entre eles, } \\
\text { entre eles e a tecnologia e, } \\
\text { principalmente, entre eles e } \\
\text { a escola. }\end{array}$ & $\begin{array}{l}\text { Os resultados da pesquisa } \\
\text { demostraram como a } \\
\text { comunicação, por meio do uso } \\
\text { do celular, contribui e se } \\
\text { aproxima, de forma efetiva, } \\
\text { com processos educativos na } \\
\text { formação cidadã dos jovens. A } \\
\text { experiência também aponta } \\
\text { para a necessidade de se } \\
\text { ampliar o debate e as práticas } \\
\text { audiovisuais nos processos } \\
\text { pedagógicos, aproveitando } \\
\text { diferentes tecnologias de } \\
\text { comunicação que já fazem } \\
\text { parte do cotidiano dos } \\
\text { estudantes. }\end{array}$ \\
\hline 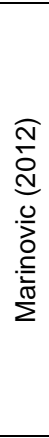 & $\begin{array}{l}\text { Produção de } \\
\text { vídeos caseiros } \\
\text { pelos próprios } \\
\text { alunos como } \\
\text { estratégia para } \\
\text { melhorar a } \\
\text { aprendizagem } \\
\text { dos conceitos } \\
\text { abordados nas } \\
\text { aulas regulares } \\
\text { de física do } \\
\text { ensino médio... }\end{array}$ & $\begin{array}{l}\text { Verificar a eficiência da } \\
\text { produção de vídeos caseiros } \\
\text { pelos próprios alunos em } \\
\text { busca da melhoria na } \\
\text { aprendizagem de física. }\end{array}$ & $\begin{array}{l}\text { A atividade motiva os alunos a } \\
\text { pesquisar e trabalhar em } \\
\text { grupo. Os vídeos precários, } \\
\text { com pouca qualidade técnica e } \\
\text { de conteúdo, evidenciam a } \\
\text { pouca participação e interesse } \\
\text { dos alunos que os produziram. }\end{array}$ \\
\hline 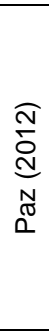 & $\begin{array}{l}\text { Saracuruna } \\
\text { News: produção } \\
\text { audiovisual } \\
\text { como dispositivo } \\
\text { de subjetivação } \\
\text { entre jovens da } \\
\text { periferia de } \\
\text { Duque de } \\
\text { Caxias }\end{array}$ & $\begin{array}{l}\text { Apresentar um conjunto de } \\
\text { reflexões sobre produção de } \\
\text { subjetividades em } \\
\text { experiências de produção } \\
\text { audiovisual no espaço } \\
\text { educativo formal. }\end{array}$ & $\begin{array}{l}\text { Percebe a produção de vídeo } \\
\text { como um dispositivo que } \\
\text { provocou processos de } \\
\text { subjetivação em seus } \\
\text { participantes. }\end{array}$ \\
\hline 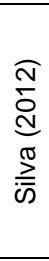 & $\begin{array}{l}\text { Arte, mídia e } \\
\text { cinema na } \\
\text { escola }\end{array}$ & $\begin{array}{l}\text { Identificar pistas de uma } \\
\text { possível proposta de ensino } \\
\text { sobre cinema na escola } \\
\text { incluindo o uso das } \\
\text { tecnologias e da produção } \\
\text { audiovisual na perspectiva } \\
\text { da mídia-educação. }\end{array}$ & $\begin{array}{l}\text { Apresenta uma proposta de } \\
\text { ensino, a Oficina de Cinema, } \\
\text { como possibilidade de inserção } \\
\text { curricular para trabalhar o } \\
\text { cinema e sua articulação com } \\
\text { a arte e a mídia em sala de } \\
\text { aula. }\end{array}$ \\
\hline 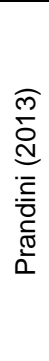 & $\begin{array}{l}\text { A cor na voz: } \\
\text { linguagem e } \\
\text { identidade } \\
\text { negra em } \\
\text { histórias de vida } \\
\text { digitalizadas } \\
\text { contadas por } \\
\text { meio de práticas } \\
\text { educomunicativ } \\
\text { as }\end{array}$ & $\begin{array}{l}\text { Analisar, por meio de seus } \\
\text { próprios discursos, os } \\
\text { processos de construção de } \\
\text { identidade negra de jovens } \\
\text { do Ensino Fundamental II de } \\
\text { uma escola pública da } \\
\text { periferia da cidade de São } \\
\text { Paulo. }\end{array}$ & $\begin{array}{l}\text { Os sujeitos deram início a um } \\
\text { processo de conscientização } \\
\text { em relação a si mesmos e ao } \\
\text { grupo social, o que se torna } \\
\text { possível graças ao } \\
\text { distanciamento propiciado pelo } \\
\text { ato de se autonarrar. }\end{array}$ \\
\hline 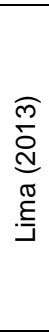 & $\begin{array}{l}\text { Atenção } \\
\text { gravando! } \\
\text { Produção de } \\
\text { vídeos por } \\
\text { alunos do } \\
\text { ensino médio - a } \\
\text { língua como } \\
\text { objeto de } \\
\text { reflexão }\end{array}$ & $\begin{array}{l}\text { Analisar o uso de vídeos } \\
\text { como recurso de } \\
\text { aprendizagem e de interação } \\
\text { dos alunos nas aulas de } \\
\text { Língua Portuguesa. }\end{array}$ & $\begin{array}{l}\text { Os resultados esperados pelo } \\
\text { professor nem sempre casam } \\
\text { com os objetivos das } \\
\text { atividades pelo fato de para o } \\
\text { aluno não ficar clara a meta da } \\
\text { atividade. }\end{array}$ \\
\hline
\end{tabular}




\begin{tabular}{|c|c|c|c|}
\hline 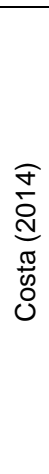 & $\begin{array}{l}\text { Pedagogia da } \\
\text { imagem: a } \\
\text { autoria na } \\
\text { relação } \\
\text { educador/educa } \\
\text { ndo durante o } \\
\text { processo de } \\
\text { produção de } \\
\text { vídeos na } \\
\text { escola }\end{array}$ & $\begin{array}{l}\text { Analisou e debater sobre um } \\
\text { pequeno recorte da } \\
\text { Pedagogia da Imagem no } \\
\text { processo de autoria na } \\
\text { relação educador / educando } \\
\text { durante produções de vídeos } \\
\text { documentários científicos } \\
\text { realizados na disciplina de } \\
\text { ciências. }\end{array}$ & $\begin{array}{l}\text { Durante o processo de } \\
\text { produção dos vídeos } \\
\text { documentários científicos, os } \\
\text { alunos atuaram de forma ativa } \\
\text { e inovadora dentro e fora do } \\
\text { ambiente escolar, colocando } \\
\text { em prática os conteúdos } \\
\text { ministrados na disciplina de } \\
\text { ciências, envolvendo a arte } \\
\text { cinematográfica e as } \\
\text { tecnologias digitais em suas } \\
\text { obras, indicadores de marcas } \\
\text { de autoria. }\end{array}$ \\
\hline 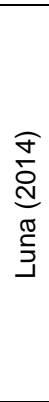 & $\begin{array}{l}\text { Luz, câmera, } \\
\text { ação: os vídeos } \\
\text { na educação em } \\
\text { ciências e } \\
\text { produção de } \\
\text { saberes }\end{array}$ & $\begin{array}{l}\text { Analisar os discursos que } \\
\text { instituem práticas } \\
\text { envolvendo os estudantes } \\
\text { em suas relações com a } \\
\text { escola e com o mundo. }\end{array}$ & $\begin{array}{l}\text { A exibição e a produção de } \\
\text { vídeos podem ser uma boa } \\
\text { estratégia para o ensino de } \\
\text { Ciências, com } \\
\text { desenvolvimento de } \\
\text { aprendizagens - conceituais, } \\
\text { procedimentais e atitudinais - } \\
\text { por jovens que têm habilidades } \\
\text { para lidar com as mídias e que } \\
\text { fazem isso com bastante } \\
\text { motivação e autonomia. }\end{array}$ \\
\hline 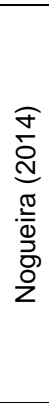 & $\begin{array}{l}\text { Letramento(s) } \\
\text { digital(is) e } \\
\text { jovens de } \\
\text { periferia: o } \\
\text { transitar por } \\
\text { (multi)letrament } \\
\text { o(s) digital(is) } \\
\text { durante o } \\
\text { processo de } \\
\text { produção de } \\
\text { vídeos de bolso }\end{array}$ & $\begin{array}{l}\text { Analisar os tipos de } \\
\text { letramento(s) digital(is) } \\
\text { mobilizados por jovens de } \\
\text { periferia durante a produção } \\
\text { de vídeos de bolso. }\end{array}$ & $\begin{array}{l}\text { Fica evidenciada a capacidade } \\
\text { dos jovens pesquisados } \\
\text { transitarem por diferentes } \\
\text { letramentos digitais, de modo } \\
\text { hipertextual e não linear, } \\
\text { buscando informações de } \\
\text { forma autônoma no espaço } \\
\text { virtual, (re)significando, desta } \\
\text { forma, seus usos e aplicações. }\end{array}$ \\
\hline 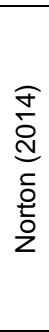 & $\begin{array}{l}\text { O cinema e o } \\
\text { rural em uma } \\
\text { escola no } \\
\text { campo }\end{array}$ & $\begin{array}{l}\text { Investigar como o cinema } \\
\text { dentro da escola dialoga } \\
\text { com a educação e, em } \\
\text { particular, no caso da escola } \\
\text { rural, como ele pode } \\
\text { construir ou ressignificar a } \\
\text { relação do aluno e da escola } \\
\text { com a realidade do campo. }\end{array}$ & $\begin{array}{l}\text { A experiência de ver filmes e } \\
\text { fazer exercícios de produção } \\
\text { audiovisual permite que os } \\
\text { alunos descubram, reinventem } \\
\text { e ressignifiquem o } \\
\text { conhecimento; o cinema tem a } \\
\text { capacidade de criar e projetar } \\
\text { reflexos do que nós somos e } \\
\text { ou queremos ser. }\end{array}$ \\
\hline 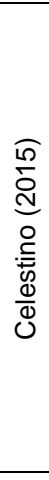 & $\begin{array}{l}\text { Crianças e suas } \\
\text { narrativas } \\
\text { audiovisuais }\end{array}$ & $\begin{array}{l}\text { Perceber como as crianças } \\
\text { criam utilizando áudio e } \\
\text { vídeo, e a infância aparece } \\
\text { como protagonista numa } \\
\text { concepção de criança como } \\
\text { produtora dessa cultura. }\end{array}$ & $\begin{array}{l}\text { Nas oficinas ocorre a } \\
\text { apropriação das crianças de } \\
\text { narrativas audiovisuais - } \\
\text { trazendo seus repertórios e } \\
\text { utilizando os aparatos técnicos } \\
\text { para também contar e produzir } \\
\text { suas histórias com áudio e } \\
\text { vídeo, revelando } \\
\text { conhecimentos capazes de } \\
\text { trazerem contribuições } \\
\text { importantes e generosas para } \\
\text { a formação delas e de todos } \\
\text { nós. }\end{array}$ \\
\hline
\end{tabular}




\begin{tabular}{|c|c|c|c|}
\hline 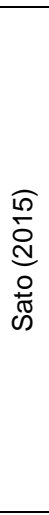 & $\begin{array}{l}\text { Tecnologias } \\
\text { digitais da } \\
\text { informação e } \\
\text { comunicação } \\
\text { : explorando } \\
\text { as } \\
\text { possibilidade } \\
\text { s } \\
\text { pedagógicas } \\
\text { da produção } \\
\text { de vídeos }\end{array}$ & $\begin{array}{l}\text { Explorar as possibilidades } \\
\text { pedagógicas do uso das } \\
\text { TDIC nos anos iniciais do } \\
\text { ensino fundamental. }\end{array}$ & $\begin{array}{l}\text { Os alunos assistem vídeos } \\
\text { com o uso de diferentes } \\
\text { recursos tecnológicos, } \\
\text { utilizam as tecnologias } \\
\text { (celular, tablet) para o } \\
\text { divertimento, filmam } \\
\text { momentos do cotidiano e } \\
\text { compartilham na Internet. A } \\
\text { apropriação de } \\
\text { conhecimentos pelos alunos } \\
\text { para a produção de vídeos } \\
\text { digitais por meio da ajuda } \\
\text { de sujeitos mais } \\
\text { experientes. }\end{array}$ \\
\hline 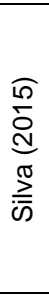 & $\begin{array}{l}\text { Luz, câmera, } \\
\text { assimetria na } \\
\text { inter-ação: } \\
\text { funções do } \\
\text { professor } \\
\text { assumidas por } \\
\text { alunos }\end{array}$ & $\begin{array}{l}\text { Investigar a interação aluno- } \\
\text { aluno na ausência do } \\
\text { professor; observar como } \\
\text { esses alunos recepcionam } \\
\text { atividades do processo de } \\
\text { letramento digital com } \\
\text { estrutura adequada para o } \\
\text { ensino de novas tecnologias. }\end{array}$ & $\begin{array}{l}\text { Foi possível perceber que, na } \\
\text { ausência do docente, a } \\
\text { assimetria estabeleceu-se na } \\
\text { medida em que os estudantes } \\
\text { assumiram para si a função de } \\
\text { animar, que comumente é } \\
\text { prerrogativa do educador. }\end{array}$ \\
\hline 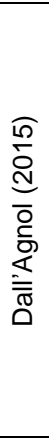 & $\begin{array}{l}\text { Produção } \\
\text { audiovisual } \\
\text { como recurso } \\
\text { didático- } \\
\text { pedagógico no } \\
\text { ensino de } \\
\text { história: "como } \\
\text { me veem?", } \\
\text { "como eu vejo?" }\end{array}$ & $\begin{array}{l}\text { Desenvolver uma } \\
\text { metodologia, com o uso da } \\
\text { produção audiovisual no } \\
\text { ensino de História, } \\
\text { trabalhando os conceitos de } \\
\text { identidade e pertença de } \\
\text { adolescentes. }\end{array}$ & $\begin{array}{l}\text { O exercício de refletir sobre } \\
\text { "como os outros me veem", } \\
\text { viabilizou que o adolescente } \\
\text { pensasse sobre a } \\
\text { representação do estereótipo } \\
\text { de criminalidade, violência e } \\
\text { inferioridade que Ihes fora } \\
\text { emulado ideologicamente, } \\
\text { conseguindo assim, que o } \\
\text { mesmo crie um pensamento } \\
\text { crítico a respeito da própria } \\
\text { realidade. }\end{array}$ \\
\hline 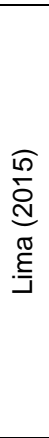 & $\begin{array}{l}\text { Literacinese ou } \\
\text { da escrita } \\
\text { [literária] com } \\
\text { imagens... Em } \\
\text { movimento }\end{array}$ & $\begin{array}{l}\text { Realizar um estudo sobre a } \\
\text { relação entre literatura e } \\
\text { cinema, na educação; } \\
\text { analisar as relações entre } \\
\text { literatura e cinema no que } \\
\text { concerne ao ensino de } \\
\text { Literatura no ensino médio, } \\
\text { propondo uma forma } \\
\text { diferenciada de articular } \\
\text { literatura e cinema, } \\
\text { educação e cinema na } \\
\text { escola. }\end{array}$ & $\begin{array}{l}\text { Buscou apontar, assim, o } \\
\text { cinema não como arte } \\
\text { secundária à literatura, mas } \\
\text { como arte independente da } \\
\text { mesma, apesar de alimentar- } \\
\text { se dela. }\end{array}$ \\
\hline 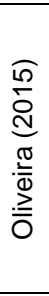 & $\begin{array}{l}\text { Uma } \\
\text { metodologia } \\
\text { para a produção } \\
\text { de audiovisual: } \\
\text { o uso de } \\
\text { tecnologias } \\
\text { emergentes } \\
\text { com os jovens }\end{array}$ & $\begin{array}{l}\text { Analisar o processo criativo } \\
\text { de construção de narrativas } \\
\text { e produção audiovisual de } \\
\text { jovens. }\end{array}$ & $\begin{array}{l}\text { Os jovens são capazes de se } \\
\text { inserir na cultura digital, com } \\
\text { uma atitude mais crítica e } \\
\text { criativa se tiverem a tecnologia } \\
\text { e o conhecimento audiovisual } \\
\text { como aliados. }\end{array}$ \\
\hline 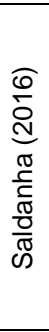 & $\begin{array}{l}\text { Oficina } \\
\text { educomunicativ } \\
\text { a de produção } \\
\text { de vídeos: } \\
\text { construção de } \\
\text { significados } \\
\text { sobre } \\
\text { problemas } \\
\text { socioambientais }\end{array}$ & $\begin{array}{l}\text { Analisar a construção de } \\
\text { significados por alunos sobre } \\
\text { os problemas } \\
\text { socioambientais do seu } \\
\text { entorno a partir das } \\
\text { capacidades de leitura e } \\
\text { expressão audiovisual }\end{array}$ & $\begin{array}{l}\text { A oficina colaborou para que } \\
\text { os alunos refletissem sobre } \\
\text { sua maneira de aprender por } \\
\text { meio da utilização crítica das } \\
\text { técnicas de leitura e produção } \\
\text { de mídia. }\end{array}$ \\
\hline
\end{tabular}


Investigar como o gesto cinematográfico pode perturbar o espaço escolar, refletindo sobre a desestabilização do status quo e as tensões que emergem no encontro entre estudantes e o cinema, em seu sentido expandido e entendido enquanto arte.

Cartografar alguns verbetes de um abecedário audiovisual produzido com alunos da Escola de Cinema Cinead: CineZé, e algumas ações do processo de elaboração dos conceitos.
A criação cinematográfica no espaço escolar

pode ser um dispositivo que possibilita a transformação do indivíduo, da percepção do Outro e da visão de mundo, pois abre outro espaço de sensibilização e de enunciação, na medida em que Ihe oferece autonomia, protagonismo e o uso de outras linguagens, relacionando diversos saberes, a abertura para a prática da experimentação e outras formas de compreender a si e ao espaço escolar numa parceria entre educação básica e universidade pública.

A dissertação-abecedário resulta de uma montagem de ideias e imagens reunidas como experiência estética, escrita e audiovisual de conhecimento sensível, com um filme-abecedário que complementa o processo. No final, a formulação de algumas considerações acerca da escola pública atual espremida por interesses dos mais diversos - aposta no cinema como uma das possibilidades dela estabelecer um encontro tátil, de amor e cuidado com mundo. 